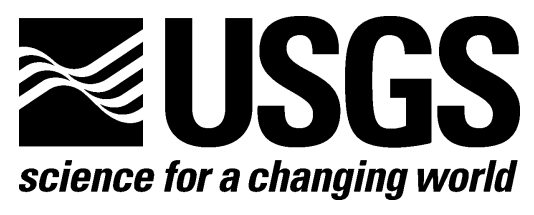

Prepared in cooperation with the Urban Drainage and Flood Control District

\title{
Summary and Evaluation of the Quality of Stormwater in Denver, Colorado, 2006-2010
}

By Michael R. Stevens and Cecil B. Slaughter

Open-File Report 2012-1052

U.S. Department of the Interior

U.S. Geological Survey 


\title{
U.S. Department of the Interior \\ KEN SALAZAR, Secretary
}

\author{
U.S. Geological Survey \\ Marcia K. McNutt, Director
}

U.S. Geological Survey, Reston, Virginia: 2012

For product and ordering information:

World Wide Web: http://www.usgs.gov/pubprod

Telephone: 1-888-ASK-USGS

For more information on the USGS-the Federal source for science about the Earth, its natural and living resources, natural hazards, and the environment:

World Wide Web: http://www.usgs.gov

Telephone: 1-888-ASK-USGS

Suggested citation:

Stevens, M.R., and Slaughter, C.B., 2012, Summary and evaluation of the quality of stormwater in Denver, Colorado, 2006-2010: U.S. Geological Survey Open-File Report 2012-1052, 94 p.

Any use of trade, product, or firm names is for descriptive purposes only and does not imply endorsement by the U.S. Government.

Although this report is in the public domain, permission must be secured from the individual copyright owners to reproduce any copyrighted material contained within this report. 


\section{Acknowledgments}

The authors gratefully acknowledge the knowledge and insight provided by Ken

MacKenzie, Manager, Master Planning Program, Urban Drainage and Flood Control District.

Technical reviews were provided by Katherine Walton-Day and Michael Sweat, U.S.

Geological Survey. Editorial reviews were provided by Michael Deacon and Betty Palcsak, U.S. Geological Survey. Field and technical assistance was provided by Dennis Smits, Clifford Bossong, and Andrea Fleming, U.S. Geological Survey. 


\section{Contents}

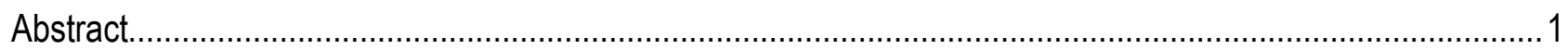

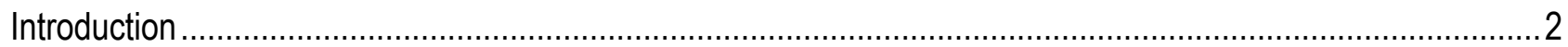

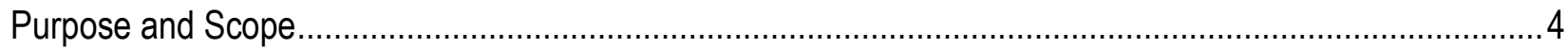

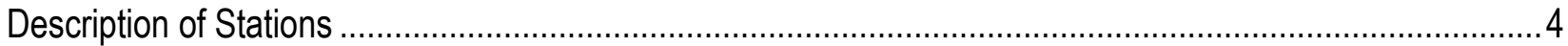

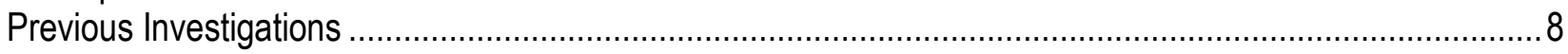

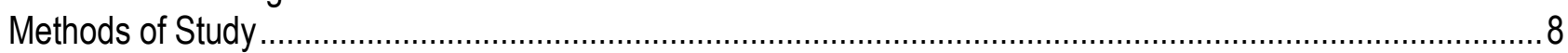

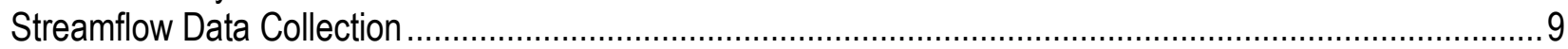

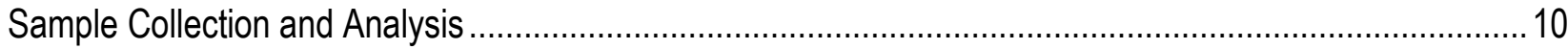

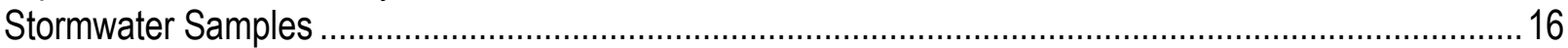

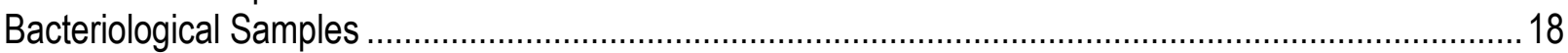

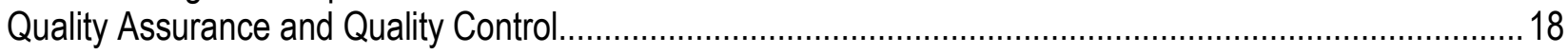

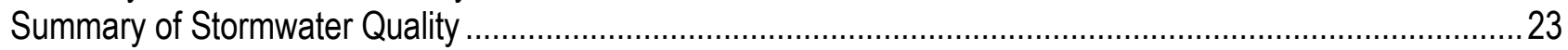

Water Quality of Stormwater Samples ..........................................................................................

Comparison to Colorado Water-Quality Standards ............................................................................52

Evaluation of Stormwater Quality between 2002-2005 and 2006-2010 ................................................55

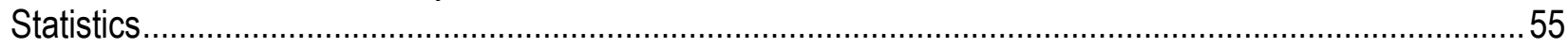

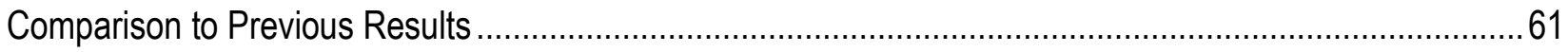

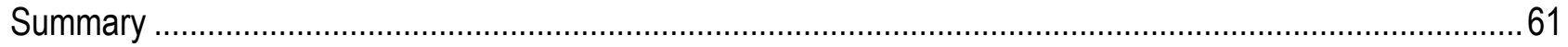

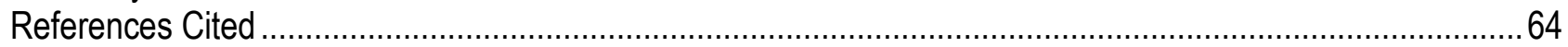

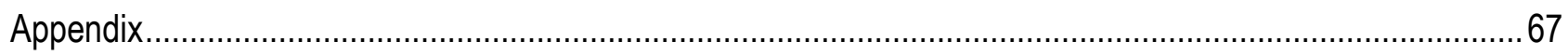

\section{Figures}

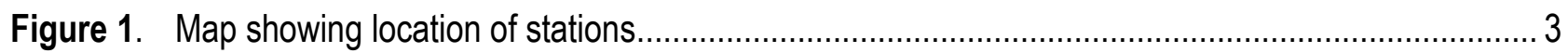

Figure 2. Explanation for boxplots shown in this report ................................................................ 17

Figure 3. Graphs showing daily values for streamflow and precipitation and dates of sample collection (2006-2010) at South Platte River below Union Avenue at Englewood, South Platte River at Denver, Toll Gate Creek above 6th Avenue at Aurora, Sand Creek at mouth near Commerce City, and South Platte River at Henderson.

Figure 4. Boxplots showing distribution of water-quality properties and constituents at South Platte River below Union Avenue at Englewood, South Platte River at Denver, Toll Gate Creek above 6th Avenue at Aurora, Sand Creek at mouth near Commerce City, and South Platte River at Henderson, calendar years 1998-2001, 2002-2005, and 2006-2010. 


\section{Tables}

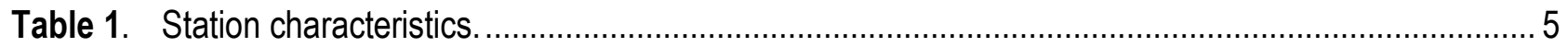

Table 2. Land-cover characteristics. ......................................................................................

Table 3. Streamflow statistics for 2006-2010 water years and calendar years........................................ 9

Table 4. Statistics for concentrations and measurement values at stormwater sampling

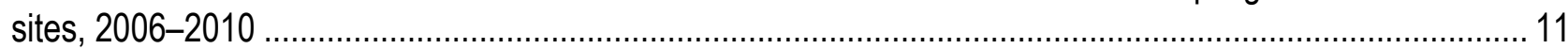

Table 5. Analytical results for quality-assurance blanks, 2006-2010 ................................................ 19

Table 6. Relative percentage difference statistics for duplicate samples collected during 2006-2010 ......... 22

Table 7. Statistics for concentrations and measurement values at stormwater sampling sites, 2006-2010

Table 8. Summary of Colorado water-quality standards and properties and constituents that exceeded Colorado standards for this study, 2006-2010

Table 9. Mann-Whitney test of differences between distributions of water-quality values and concentrations in stormwater samples collected in 2002-2005 and 2006-2010 at all sites.

\section{Appendix}

Table A1. Statistics for concentrations and measurement values at South Platte River below Union Avenue at Englewood by year, 2006-2010

Table A2. Statistics for concentrations and measurement values at South Platte River at Denver by year, 2006-2010.

Table A3. Statistics for concentrations and measurement values at Toll Gate Creek above 6th Avenue at Aurora by year, 2006-2010

Table A4. Statistics for concentrations and measurement values at Sand Creek at mouth near

Commerce City by year, 2006-2010.

Table A5. Statistics for concentrations and measurement values at South Platte River at Henderson by year, 2006-2010 


\section{Conversion Factors and Abbreviations}

\begin{tabular}{lcl}
\hline \multicolumn{1}{c}{ Multiply } & By & \multicolumn{1}{c}{ To obtain } \\
\hline \multicolumn{3}{c}{ Area } \\
square mile $\left(\mathrm{mi}^{2}\right)$ & 259.0 & hectare $($ ha) \\
square mile $\left(\mathrm{mi}^{2}\right)$ & 2.590 & square kilometer $\left(\mathrm{km}^{2}\right)$ \\
\hline \multicolumn{3}{c}{ Volume } \\
\hline gallon (gal) & 3.785 & liter $(\mathrm{L})$ \\
acre-foot $($ acre-ft) & 1,233 & cubic meter $\left(\mathrm{m}^{3}\right)$ \\
acre-foot $($ acre-ft) & 0.001233 & cubic hectometer $\left(\mathrm{hm}^{3}\right)$ \\
\hline & Flow rate & \\
\hline cubic foot per second $\left(\mathrm{ft}^{3} / \mathrm{s}\right)$ & 0.02832 & cubic meter per second $\left(\mathrm{m}^{3} / \mathrm{s}\right)$ \\
\hline
\end{tabular}

$\begin{array}{ll}\text { ALERT } & \text { Automated Local Evaluation in Real Time } \\ \text { CODWR } & \text { Colorado Division of Water Resources } \\ \text { CDPHE } & \text { Colorado Department of Public Health and Environment } \\ \text { QA/QC } & \text { Quality assurance and quality control } \\ \text { MWRD } & \text { Metropolitan Wastewater Reclamation District } \\ \text { NWIS } & \text { National Water Information System } \\ \text { NWQL } & \text { National Water Quality Laboratory } \\ \text { RPD } & \text { Relative percent difference } \\ \text { UBL } & \text { Universal blank water } \\ \text { UDFCD } & \text { Urban Drainage and Flood Control District } \\ \text { USGS } & \text { U.S. Geological Survey }\end{array}$

Temperature in degrees Celsius $\left({ }^{\circ} \mathrm{C}\right)$ may be converted to degrees Fahrenheit $\left({ }^{\circ} \mathrm{F}\right)$ as follows: ${ }^{\circ} \mathrm{F}=\left(1.8 \mathrm{x}^{\circ} \mathrm{C}\right)+32$

Temperature in degrees Fahrenheit $\left({ }^{\circ} \mathrm{F}\right)$ may be converted to degrees Celsius $\left({ }^{\circ} \mathrm{C}\right)$ as follows: ${ }^{\circ} \mathrm{C}=\left({ }^{\circ} \mathrm{F}-32\right) / 1.8$

Horizontal coordinate information is referenced to the North American Datum of 1983 (NAD83) Specific conductance is given in microsiemens per centimeter at 25 degrees Celsius $\left(\mu \mathrm{S} / \mathrm{cm}\right.$ at $\left.25^{\circ} \mathrm{C}\right)$. Concentrations of chemical constituents in water are given either in milligrams per liter $(\mathrm{mg} / \mathrm{L})$ or micrograms per liter $(\mu \mathrm{g} / \mathrm{L})$.

Water year is defined in this report as the 12-month period October 1 through September 30, designated by the calendar year in which it ends. 


\title{
Summary and Evaluation of the Quality of Stormwater in Denver, Colorado, 2006-2010
}

\author{
By Michael R. Stevens and Cecil B. Slaughter
}

\section{Abstract}

Stormwater in the Denver area was sampled by the U.S. Geological Survey, in cooperation with the Urban Drainage and Flood Control District, in a network of 5 monitoring stations -3 on the South Platte River and 2 on streams tributary to the South Platte River, Sand Creek, and Toll Gate Creek beginning in January 2006 and continuing through December 2010. Stormwater samples were analyzed at the U.S. Geological Survey National Water Quality Laboratory during 2006-2010 for water-quality properties such as $\mathrm{pH}$, specific conductance, hardness, and residue on evaporation at 105 degrees Celsius; for constituents such as major ions (calcium, magnesium), organic carbon and nutrients, including ammonia plus organic nitrogen, ammonia, dissolved nitrite plus nitrate, total phosphorus, and orthophosphate; and for metals, including total recoverable and dissolved phases of copper, lead, manganese, and zinc. Samples collected during selected storms were also analyzed for bacteriological indicators such as Escherichia coli and fecal coliform at the Metro Wastewater Reclamation Laboratory.

About 200 stormwater samples collected during storms characterize the quality of storm runoff during 2006-2010. In general, the quality of stormwater (2006-2010) has improved for many water-quality constituents, many of which had lower values and concentrations than those in stormwater collected in 2002-2005. However, the physical basis, processes, and the role of dilution that account for these changes are complex and beyond the scope of this report.

The water-quality sampling results indicate few exceptions to standards except for dissolved manganese, dissolved zinc, and Escherichia coli. Stormwater collected at the South Platte River below Union Avenue station had about 10 percent acute or chronic dissolved manganese exceedances in samples; samples collected at the South Platte River at Denver station had less than 5 percent acute or chronic dissolved manganese exceedances. In contrast, samples collected at Toll Gate Creek above 6th Avenue at Aurora station, Sand Creek at mouth near Commerce City station, and the South Platte River at Henderson station, each had about 30 to 50 percent exceedances of both acute and chronic dissolved manganese standards. Of the samples collected at Sand Creek at mouth near Commerce City, 1 sample exceeded the acute standard and 4 samples exceeded the chronic standard for dissolved zinc, but no samples collected from the other sites exceeded either standard for zinc. Almost all samples of stormwater analyzed for Escherichia coli exceeded Colorado numeric standards. A numerical standard for fecal coliform is no longer applicable as of 2004.

Results from the 2002-2005 study indicated that the general quality of stormwater had improved during 2002-2005 compared to 1998-2001, having fewer exceedances of Colorado standards, and showing downward trends for many water-quality values and concentrations. These trends coincided with general downward or relatively similar mean streamflows for the 2002-2005 
compared to 1998-2001, which indicates that dilution may be a smaller influence on values and concentrations than other factors. For this report, downward trends were indicated for many constituents at each station during 2006-2010 compared to 2002-2005. The trends for mean streamflow for 2006-2010 compared to 2002-2005 are upward at all sites except for the South Platte River at Henderson, indicating that dilution by larger flows could be a factor in the downward concentration trends. At the South Platte River below Union Avenue station, downward trends were indicated for hardness, dissolved ammonia, dissolved orthophosphate, and dissolved copper. Upward trends at South Platte River below Union Avenue were indicated for $\mathrm{pH}$. At the South Platte River at Denver station, downward trends were indicated for total ammonia plus organic nitrogen, dissolved ammonia, dissolved nitrite plus nitrate, dissolved orthophosphate, total phosphorus, dissolved organic carbon, and dissolved lead, manganese, and zinc, and total recoverable zinc. An upward trend in properties and constituents at South Platte River at Denver was indicated for $\mathrm{pH}$. At Toll Gate Creek above 6th Avenue at Aurora, downward trends were indicated for residue on evaporation, total ammonia plus organic nitrogen, dissolved ammonia, dissolved orthophosphate, total phosphorus, and total recoverable copper, lead, manganese, and zinc. Upward trends in properties and constituents at Toll Gate Creek above 6th Avenue at Aurora were indicated for $\mathrm{pH}$, specific conductance, and dissolved nitrite plus nitrate. At Sand Creek at mouth near Commerce City, downward trends were indicated for hardness, dissolved calcium, total ammonia plus organic nitrogen, and dissolved ammonia, orthophosphate, manganese, and zinc. An upward trend in properties and constituents at Sand Creek at mouth near Commerce City was indicated for $\mathrm{pH}$. Downward trends at South Platte River at Henderson were indicated for specific conductance, hardness, dissolved magnesium, residue on evaporation, total ammonia plus organic nitrogen, dissolved ammonia, dissolved nitrite plus nitrate, dissolved orthophosphate, total phosphorus, dissolved lead and manganese, and total recoverable copper, lead, manganese, and zinc.

\section{Introduction}

The quality of stormwater runoff and trend of water quality in stormwater runoff is of interest to many management and regulatory agencies as well as scientists, recreational stream users, and the general public. The basic character of stormwater runoff is of general interest to all, and more detailed information concerning spatial and temporal variations in stormwater quality may be of interest to management and regulatory agencies. In response to these interests, the U.S. Geological Survey (USGS), in cooperation with the Urban Drainage and Flood Control District (UDFCD), collected stormwater samples during wet weather from a monitoring network of five stations in and around metropolitan Denver, Colorado. The monitoring network is the basis for evaluation of stormwater conditions in Aurora, Denver, and Lakewood, and consists of three stations on the South Platte River, the principal stream draining the area and two stations on streams that are tributary to the South Platte River, Sand Creek and Toll Gate Creek (fig. 1). Reaches of each of these streams have use classifications and associated numeric standards for some water-quality properties and constituents and bacteriological indicators included in this study, such as $\mathrm{pH}$, dissolved nitrite plus nitrate, dissolved copper, lead, manganese, zinc, and Escherichia coli, (Colorado Department of Public Health and Environment, 2011a, 2011b). 


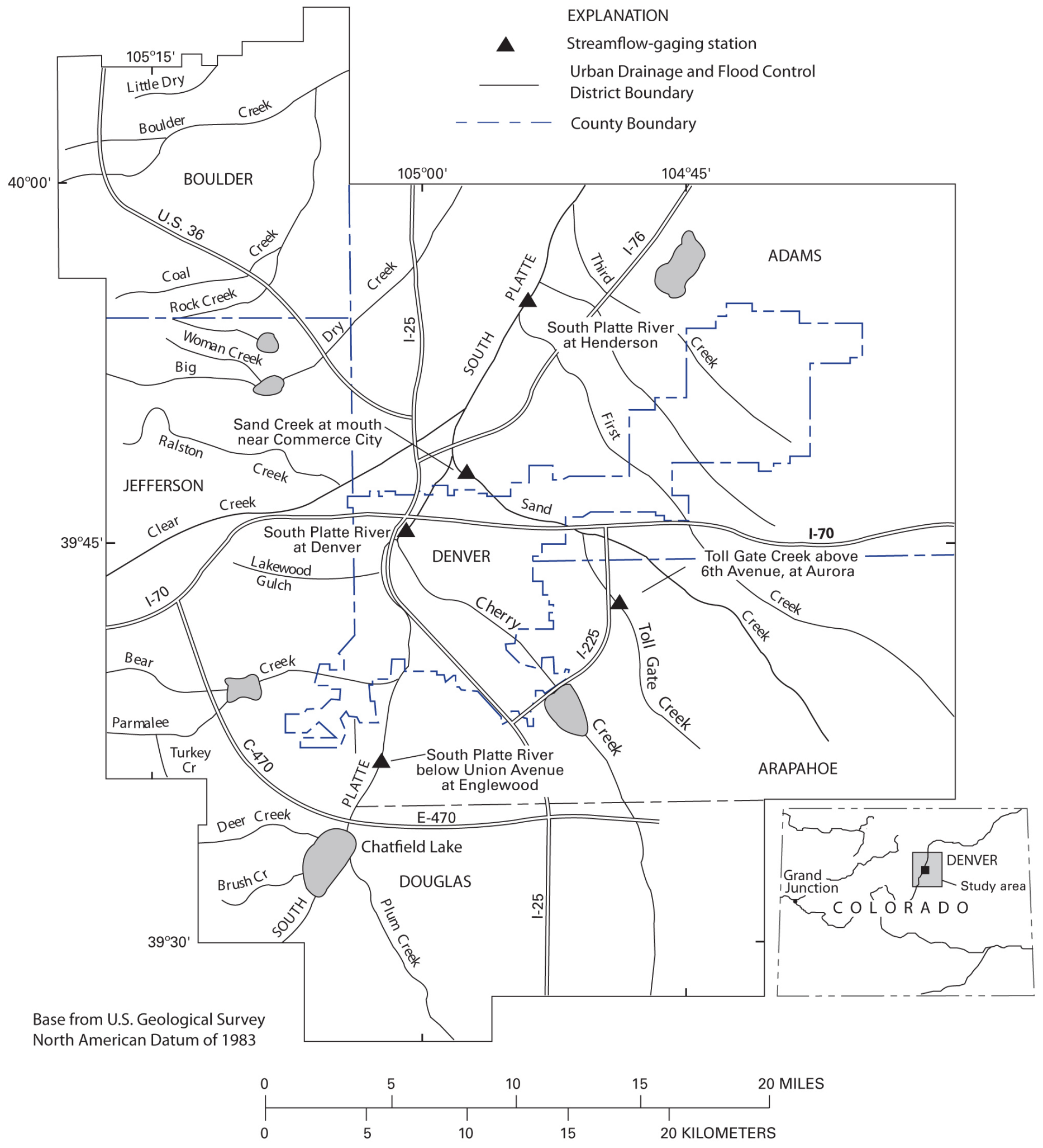

Figure 1. Map showing location of stations. 


\section{Purpose and Scope}

The purpose of this report is to present summaries and an evaluation of laboratory analyses for water-quality properties and constituents and bacteriological indicators in stormwater samples that characterize the quality of stormwater in and around metropolitan Denver, Colo., from January 2006 through December 2010. Specifically, the summaries and evaluation in this report include

- characterizations that summarize streamflow associated with stormwater samples,

- descriptive statistics that summarize stormwater quality,

- comparisons of stormwater quality with numeric standards for use classifications established by the CDPHE, and

- comparison of previous characterizations of stormwater quality, based on data collected during 2002-2005 to the stormwater quality characterized in this report (2006-2010).

The summary presented in this report (2006-2010) provides a basis for comparison to similar data (1998-2001 and 2002-2005); however, the physical basis and processes responsible for changes between the two periods are complex and are beyond the scope of this report.

\section{Description of Stations}

The five stations in the monitoring network include three stations on the main stem of the South Platte River (fig. 1; table 1). These three stations, South Platte River below Union Avenue at Englewood, South Platte River at Denver, and South Platte River at Henderson, will be referred to in this report as "Union," "Denver," and "Henderson." The stations on the South Platte River receive streamflow from several tributaries, and the South Platte River is sometimes referred to as a "receiving stream." The two additional stations, Sand Creek at mouth near Commerce City and Toll Gate Creek above 6th Avenue at Aurora, represent tributaries and are referred to in this report as "Sand Creek" and "Toll Gate." Sand Creek is tributary to the South Platte River, and Toll Gate is tributary to Sand Creek. Collectively, these five stations define a drainage system that drains most of the area in and around metropolitan Denver. 
Table 1. Station characteristics.

[Station number and name from the U.S. Geological Survey (USGS) National Water Inventory System. Latitude and Longitude (North American Datum of 1927), geographic coordinates in degrees minutes seconds; Operating agency indicates agency responsible for streamflow records: CODWR, Colorado Division of Water Resources; UDFCD, Urban Drainage and Flood Control District. RF location, location of precipitation gage associated with station, the source for all precipitation records is UDFCD]

\begin{tabular}{|c|c|c|c|c|c|c|}
\hline \multirow{2}{*}{ Station number } & \multirow{2}{*}{ Station name } & \multicolumn{2}{|c|}{ Station location } & \multirow{2}{*}{$\begin{array}{l}\text { Operating } \\
\text { agency }\end{array}$} & \multicolumn{2}{|c|}{ RF location } \\
\hline & & Latitude & Longitude & & Latitude & Longitude \\
\hline 06710247 & $\begin{array}{l}\text { South Platte River below Union Avenue at } \\
\text { Englewood }\end{array}$ & $39^{\circ} 37^{\prime} 57^{\prime \prime}$ & $105^{\circ} 00^{\prime} 52^{\prime \prime}$ & USGS & $39^{\circ} 37^{\prime} 57^{\prime \prime}$ & $105^{\circ} 00^{\prime} 52^{\prime \prime}$ \\
\hline 06714000 & South Platte River at Denver & $39^{\circ} 45^{\prime} 35^{\prime \prime}$ & $105^{\circ} 00^{\prime} 10^{\prime \prime}$ & CODWR & $39^{\circ} 44^{\prime} 32^{\prime \prime}$ & $104^{\circ} 59^{\prime} 58^{\prime \prime}$ \\
\hline 394329104490101 & Toll Gate Creek above 6th Avenue at Aurora & $39^{\circ} 43^{\prime} 29^{\prime \prime}$ & $104^{\circ} 49^{\prime} 01^{\prime \prime}$ & UDFCD & $39^{\circ} 43^{\prime} 30^{\prime \prime}$ & $104^{\circ} 49^{\prime} 06^{\prime \prime}$ \\
\hline 394839104570300 & Sand Creek at mouth near Commerce City & $39^{\circ} 48^{\prime} 36^{\prime \prime}$ & $104^{\circ} 57^{\prime} 00^{\prime \prime}$ & $\begin{array}{l}\text { USGS/ } \\
\text { UDFCD }\end{array}$ & $39^{\circ} 48^{\prime} 39^{\prime \prime}$ & $104^{\circ} 57^{\prime} 03^{\prime \prime}$ \\
\hline 06720500 & South Platte River at Henderson & $39^{\circ} 55^{\prime} 10^{\prime \prime}$ & $104^{\circ} 52^{\prime} 04^{\prime \prime}$ & CODWR & $39^{\circ} 55^{\prime} 19^{\prime \prime}$ & $104^{\circ} 52^{\prime} 00^{\prime \prime}$ \\
\hline
\end{tabular}


The South Platte River originates in central Colorado and has a contributing drainage area of 3,860 square miles $\left(\mathrm{mi}^{2}\right)$ at the Denver station (U.S. Geological Survey, 2006-2010). Snowmelt from mountainous areas of central Colorado is a principal source of spring streamflow in the South Platte River; however, reservoirs and diversions along the South Platte River regulate streamflow. Chatfield Lake, which is just upstream from Denver, contains the vast majority of storm runoff generated upstream from the reservoir, essentially truncating the contributing drainage area for the stations used in this study (fig. 1). Consequently, most stormwater runoff in the South Platte River in the Denver area is derived from a local contributing drainage area that does not extend upstream from Chatfield Lake.

Land-cover characteristics used in this report (table 2) represent percentages of the local contributing drainage areas for four aggregated categories developed on the basis of USGS National Land Cover data from 1992 (U.S. Geological Survey, 2003). In the aggregated classification, areas related to crops are classified as "agricultural"; areas identified as commercial, industrial, or transportation and areas related to mining, such as sand and gravel operations, are classified as "urban"; areas identified as residential or recreational are classified as "residential"; and all remaining areas are classified as "undeveloped." The local contributing drainage areas are less than 10 percent urban and consist mostly of undeveloped land (ranging from 41.6 to 76.0 percent in individual basins) and residential areas (17.8 to 50.4 percent). The agricultural landcover classification shows a tendency to increase with local contributing drainage area (from 0.7 to 3.2 percent in the South Platte main-stem stations (Union, Denver and Henderson). In the Sand Creek drainage area, agricultural land cover increases from 5.0 to 8.7 percent from Toll Gate to Sand Creek at mouth (table 2). Undeveloped and urban land cover also increases from Toll Gate to Sand Creek. 


\section{Table 2. Land-cover characteristics.}

[Station number and name from the U.S. Geological Survey (USGS) National Water Inventory System; Operating agency indicates agency responsible for streamflow records: USGS, U.S. Geological Survey; CODWR, Colorado Division of Water Resources; UDFCD, Urban Drainage and Flood Control District; CDA, contributing drainage area in square miles; LCDA, local contributing drainage area in square miles adjusted for regulation (excludes CDA upstream from Chatfield Lake for South Platte River stations). Land cover indicates percentage of LCDA on basis of National Land Cover data from 1992 (U.S. Geological Survey, 2003) for undeveloped areas (Und), agricultural areas (Ag), residential areas (Res), and urban areas (Urb); land-cover percentages may not sum to 100 percent due to rounding; comments provide important historical operational events]

\begin{tabular}{|c|c|c|c|c|c|c|c|}
\hline \multirow[t]{2}{*}{ Station number } & \multirow[t]{2}{*}{ CDA } & \multirow[t]{2}{*}{ LCDA } & \multicolumn{4}{|c|}{$\begin{array}{l}\text { Land cover, in percentage of } \\
\text { local contributing drainage } \\
\text { area }\end{array}$} & \multirow[t]{2}{*}{ Comments } \\
\hline & & & $\mathrm{Ag}$ & Urb & Res & Und & \\
\hline 06710247 & 3,090 & 76 & 0.7 & 5.8 & 50.4 & 43.1 & $\begin{array}{l}\text { Gage operated by USGS as described in Sauer and Turnipseed } \\
\text { (2010). }\end{array}$ \\
\hline 06714000 & 3,860 & 841 & 1.2 & 3.4 & 19.4 & 76.0 & $\begin{array}{l}\text { Gage operated by CODWR as described in Sauer and } \\
\text { Turnipseed (2010). }\end{array}$ \\
\hline 394329104490101 & 35 & 35 & 5.0 & 5.5 & 48.0 & 41.6 & Gage operated as part of flood warning network (UDFCD). \\
\hline 394839104570300 & 184 & 184 & 8.7 & 6.3 & 22.4 & 62.6 & $\begin{array}{l}\text { Gage operated by USGS as described in Sauer and Turnipseed } \\
\text { (2010) from } 2006 \text { to } 2009 \text {. Gage operated as part of flood } \\
\text { warning network in } 2010 \text { (UDFCD). }\end{array}$ \\
\hline 06720500 & 4,770 & 1,740 & 3.2 & 3.7 & 17.8 & 75.3 & $\begin{array}{l}\text { Gage operated by CODWR as described in Sauer and } \\
\text { Turnipseed (2010). }\end{array}$ \\
\hline
\end{tabular}




\section{Previous Investigations}

Several previous investigations of stormwater quality have been completed in the Denver area. From 1979 through 1983, annual data reports were issued summarizing stormwatermonitoring activities by the USGS for various stations in the Denver metropolitan area (Ellis, 1978; Ellis and Alley, 1979; Hall and Duncan, 1980, 1981; Gibbs, 1981; Gibbs and Doerfer, 1982; Gibbs and others, 1983). Although these activities included some sampling in the South Platte River, most of the activities focused on tributaries to the South Platte River. Blakely and others (1983) reported on washoff characteristics from two experimental plots, and Ellis and others (1984), Ellis and Mustard (1985), and Mustard and others (1985) provided additional stormwater information on the basis of the USGS stormwater-monitoring activities. The Denver Regional Council of Governments (1983) also summarized their stormwater-monitoring activities in the Denver metropolitan area.

More recently, Bossong and others (2005) summarized stormwater quality in the Denver area on the basis of samples collected during October 1997 through September 2001. The conclusions from the 2005 report indicated that concentrations in stormwater tended to increase in a downstream direction along the South Platte River, that concentrations for many water-quality properties and constituents in stormwater were relatively smaller compared to concentrations in base flow, that exceptions to CDPHE numeric standards (measured concentrations that did not meet standards) for some metals occurred in as many as 10 to 25 percent of samples, and that there were consistent exceedances of numeric standards for bacteriological indicators such as Escherichia coli and fecal coliform. In previously published USGS reports, data were grouped by water years (October 1 through September 30 of the following year). In this report, data are grouped and analyzed by calendar year.

A second report (Bossong and Fleming, 2008) summarized stormwater quality for water years 2002-2005 using methods similar to those in Bossong and others (2005). The 2002-2005 report indicated that statistically significant downward trends in concentrations were identified for the combined means of all stations for dissolved copper, manganese, and zinc, and total recoverable zinc. Downward trends between 1998-2001 means and 2002-2005 means were also relatively widespread for many constituents including hardness, ammonia plus organic nitrogen, total phosphorus, most dissolved metals (lead, manganese, and zinc), and all total recoverable metals (copper, lead, manganese, and zinc). Some trends were indicated only at individual stations. Downward trends were identified for ammonia as nitrogen at Union, Denver, and Henderson, for orthophosphate at Sand Creek, and for dissolved nitrite plus nitrate at Denver and Henderson. Only dissolved nitrite plus nitrate at Union and total recoverable copper and lead at Sand Creek showed consistent upward trends. There were many more exceedances to water-quality standards in the 1998-2001 study than in the 2002-2005 study. Escherichia coli and fecal coliform consistently exceeded bacteria standards in the 1998-2001 and the 2002-2005 reports.

\section{Methods of Study}

The methods used to collect and process streamflow data, collect and process stormwater samples, and perform laboratory analyses are described in this section. The section also describes quality-assurance and quality-control (QA/QC) methods and results. 


\section{Streamflow Data Collection}

Streamflow records are maintained for each station by various operating agencies (table 3 ). Union is operated by the USGS in accordance with methods described by (Turnipseed and Sauer, 2010; Sauer and Turnipseed, 2010). The streamflow data for Union is maintained in the USGS National Water Information System (NWIS; http://waterdata.usgs.gov/nwis/). Daily data, which represent various statistics for a 24-hour period, and subdaily data that are instantaneous values used to develop daily values, are available from NWIS. In addition, the records were published in USGS annual data reports for 2006-2010 (U.S. Geological Survey, 2006-2010).

Table 3. Streamflow statistics for 2006-2010 water years and calendar years.

[Station number and name from the U.S. Geological Survey National Water Inventory System; $\mathrm{ft}^{3} / \mathrm{s}$, cubic foot per second; Toll Gate Creek is not included in streamflow statistics because the gage is only operated seasonally; water year, the 12-month period from October 1 through September 30, and designated by the calendar year in which it ends and which includes 9 of the 12 months; calendar year, 12-month period from January 1 through December 31]

\begin{tabular}{|c|c|c|c|c|}
\hline \multirow[b]{2}{*}{ Descriptor } & \multicolumn{4}{|c|}{ Station name (number) } \\
\hline & $\begin{array}{c}\text { Union } \\
\text { (06710247) }\end{array}$ & $\begin{array}{c}\text { Denver } \\
(06714000)\end{array}$ & $\begin{array}{c}\text { Sand Creek } \\
(394839104570300)\end{array}$ & $\begin{array}{l}\text { Henderson } \\
(06720500)\end{array}$ \\
\hline & \multicolumn{4}{|c|}{ Water-year statistics ${ }^{1}$} \\
\hline Period, in water years & $2006-2010$ & $2006-2010$ & $2006-2010$ & $2006-2010$ \\
\hline Annual mean, in $\mathrm{ft}^{3} / \mathrm{s}$ & 209 & 382 & 33 & 541 \\
\hline Highest annual mean, in $\mathrm{ft}^{3} / \mathrm{s}$ & 411 & 684 & 42 & 813 \\
\hline Year it occurred & 2007 & 2007 & 2009 & 2007 \\
\hline Lowest annual mean, in $\mathrm{ft}^{3} / \mathrm{s}$ & 105 & 219 & 21 & 333 \\
\hline Year it occurred & 2006 & 2006 & 2006 & 2006 \\
\hline Highest daily mean, in $\mathrm{ft}^{3} / \mathrm{s}$ & 2,388 & 3,610 & 1,035 & 4,570 \\
\hline Date it occurred & May 2, 2007 & April 24, 2007 & April 24, 2007 & June 2, 2009 \\
\hline Lowest daily mean, in $\mathrm{ft}^{3} / \mathrm{s}$ & 5.84 & 80 & 0.74 & 44.6 \\
\hline \multirow[t]{2}{*}{ Date it occurred } & June 23, 2006 & June 14, 2006 & March 6, 2009 & January 18,2010 \\
\hline & \multicolumn{4}{|c|}{ Calendar-year statistics } \\
\hline Period, in calendar years & $2006-2010$ & 2006-2010 & $2006-2010$ & 2006-2010 \\
\hline Annual mean, in $\mathrm{ft}^{3} / \mathrm{s}$ & 209 & 386 & 33 & 531 \\
\hline Highest annual mean, in $\mathrm{ft}^{3} / \mathrm{s}$ & 412 & 685 & 45 & 813 \\
\hline Year it occurred & 2007 & 2007 & 2009 & 2007 \\
\hline Lowest annual mean, in $\mathrm{ft}^{3} / \mathrm{s}$ & 112 & 228 & 21 & 333 \\
\hline Year it occurred & 2006 & 2006 & 2006 & 2006 \\
\hline Highest daily mean, in $\mathrm{ft}^{3} / \mathrm{s}$ & 2,388 & 3,610 & 1,035 & 4,570 \\
\hline Date it occurred & May 2, 2007 & April 24, 2007 & April 24, 2007 & June 2, 2009 \\
\hline Lowest daily mean, in $\mathrm{ft}^{3} / \mathrm{s}$ & 5.84 & 80 & 0.74 & 44.6 \\
\hline Date it occurred & June 23, 2006 & June 14, 2006 & March 6, 2009 & January 18,2010 \\
\hline
\end{tabular}

${ }^{1}$ Previous reports (Bossong and others, 2005; Bossong and Fleming, 2008) grouped and analyzed data by water years, but this report groups and analyzes data by calendar year 
Denver and Henderson are operated by the Colorado Division of Water Resources (CODWR). The CODWR streamflow records at Denver and Henderson were reviewed and published by USGS for 1998-2008, but have not been reviewed and published by USGS since 2009. Daily values for 2006-2010 and instantaneous values for the most recent year are maintained on a publicly available CODWR Web-based system http://www.dwr.state.co.us/SurfaceWater/Default.aspx. All instantaneous values from Denver and Henderson are available on a UDFCD Web-based system (http://alert.udfcd.org).

Toll Gate and Sand Creek currently are operated by UDFCD using systematic but undocumented methods that involve theoretical stage and streamflow relations developed on the basis of channel geometry (Sand Creek was operated by the USGS 1998-2009 until the USGS gage location was moved). The Toll Gate and Sand Creek data are used as part of an Automated Local Evaluation in Real Time (ALERT) system operated by UDFCD to assess field conditions in a real-time mode in order to facilitate flood forecasting. Because the UDFCD data are focused on real-time information, data may be available only for periods of storm runoff. The UDFCD records consist only of instantaneous values that are archived but do not receive additional processing or review.

\section{Sample Collection and Analysis}

During 2006-2010, composite stormwater samples were collected for water-quality analysis. Composite samples integrate several aliquots of water collected over a period of time as described in the following "Stormwater Samples" section. All composite samples were collected using refrigerated automatic pumping samplers that withdraw water from a fixed point in the channel cross section. Bacteriological samples were manually collected during selected storms. The composite and bacteriological samples are collectively referred to as "stormwater samples."

Stormwater samples collected during 2006-2010 were analyzed by the USGS National Water Quality Laboratory (NWQL) in Denver, and bacteriological samples were analyzed at Metropolitan Wastewater Reclamation District (MWRD) in Denver. The results of all laboratory analyses obtained as part of this study are available in the NWIS database and can be accessed using the USGS Web interface to water data at http://waterdata.usgs.gov/co/nwis/qw/. Table 4 describes the laboratory analytical methods used in this study. Results referred to as "dissolved" are from water that has been passed through a filter that removes all particles greater than 0.45 micrometer $(\mu \mathrm{m})$ in their smallest diameter. Results referred to as "total recoverable" are from unfiltered water that has undergone an in-bottle digestion procedure (Hoffman and others, 1996). Results referred to as "whole water" are from water that has not been filtered or digested. Table 4 also lists the reporting levels. The general term "reporting level" specifies the level at which laboratory results are censored, or reported as "less than" (Helsel, 2005). The reporting level is generally twice the long-term method detection level (Childress, 1999). The long-term method detection level is determined by the NWQL based on long-term quality control performance (Childress, 1999). Laboratory quantifications of values below the reporting level are sometimes made by the laboratory on a particular analysis and are qualified as estimated. 
Table 4. Statistics for concentrations and measurement values at stormwater sampling sites, 2006-2010.

$\left[\mathrm{ft}^{3} / \mathrm{s}\right.$, cubic foot per second; $\mathrm{mL}$, milliliter; $\mu \mathrm{S} / \mathrm{cm}$, microsiemens per centimeter at 25 degrees Celsius; $\mathrm{CaCO}_{3}$, calcium carbonate; $\mathrm{mg} / \mathrm{L}$, milligrams per liter; $\mu \mathrm{g} / \mathrm{L}$, micrograms per liter; N, nitrogen; $\mathrm{P}$, phosphorus; $\mathrm{C}$, carbon; SD, standard deviation; n, number of samples; nlt, number of "less thans" or censored data; --, not calculated; \%, percentile; MPN, most probable number]

\begin{tabular}{|c|c|c|c|c|c|c|c|c|c|c|}
\hline \multirow{2}{*}{$\begin{array}{l}\text { Property or } \\
\text { constituent }\end{array}$} & \multicolumn{5}{|c|}{ Summary statistics } & \multirow{2}{*}{$\mathbf{n}$} & \multirow{2}{*}{ nlt } & \multicolumn{2}{|c|}{$\begin{array}{l}\text { Range of uncensored } \\
\text { values }\end{array}$} & \multirow{2}{*}{$\begin{array}{l}\text { Censoring } \\
\text { level }\end{array}$} \\
\hline & Mean & SD & $25 \%$ & $\begin{array}{l}\text { Median } \\
50 \% \\
\end{array}$ & $75 \%$ & & & Minimum & Maximum & \\
\hline & \multicolumn{10}{|c|}{06710247 South Platte River below Union Avenue at Englewood, Colorado } \\
\hline Streamflow, mean, $\mathrm{ft}^{3} / \mathrm{s}$ & 410 & 312 & 131 & 346 & 632 & 38 & 0 & 33 & 1,490 & -- \\
\hline Streamflow, volume, acre-feet & 378 & 282 & 136 & 322 & 574 & 38 & 0 & 30 & 1,360 & -- \\
\hline $\mathrm{pH}$, standard units & 7.7 & 0.2 & 7.6 & 7.7 & 7.8 & 38 & 0 & 6.9 & 8.4 & -- \\
\hline Specific conductance, $\mu \mathrm{S} / \mathrm{cm}$ & 490 & 210 & 345 & 409 & 585 & 38 & 0 & 226 & 993 & -- \\
\hline Hardness, total, $\mathrm{mg} / \mathrm{L}$ as $\mathrm{CaCO}_{3}$ & 145 & 47.4 & 113 & 133 & 164 & 38 & 0 & 81.5 & 290 & -- \\
\hline Calcium, mg/L & 43 & 13 & 33 & 39 & 47 & 38 & 0 & 24 & 84 & -- \\
\hline Magnesium, mg/L & 9.3 & 3.6 & 6.8 & 7.9 & 11 & 38 & 0 & 5.1 & 20 & -- \\
\hline $\begin{array}{l}\text { Suspended solids, residue on evaporation } \\
\text { at } 105^{\circ} \mathrm{C}, \mathrm{mg} / \mathrm{L} \\
\text { Nitrogen, total, ammonia plus organic as }\end{array}$ & 226 & 183 & 77 & 196 & 326 & 37 & 1 & 16 & 670 & -- \\
\hline $\begin{array}{l}\text { Nitrogen, total, ammonia plus organıc as } \\
\mathrm{N}, \mathrm{mg} / \mathrm{L}\end{array}$ & 1.4 & 0.72 & 0.83 & 1.4 & 1.7 & 8 & 0 & 0.46 & 4.00 & -- \\
\hline Nitrogen, dissolved, ammonia as $\mathrm{N}, \mathrm{mg} / \mathrm{L}$ & 0.06 & 0.06 & 0.02 & 0.05 & 0.08 & 38 & 6 & 0.01 & 6.00 & 0.01 \\
\hline Nitrogen, dissolved, nitrite plus nitrate as & & & & & & & & & & \\
\hline $\mathrm{N}, \mathrm{mg} / \mathrm{L}$ & 0.82 & 0.56 & 0.42 & 0.59 & 1.03 & 38 & 0 & 0.17 & 2.71 & - \\
\hline Orthophosphate, dissolved as $\mathrm{P}, \mathrm{mg} / \mathrm{L}$ & 0.059 & 0.051 & 0.024 & 0.043 & 0.068 & 38 & 0 & 0.004 & 0.237 & -- \\
\hline Phosphorus, total as $\mathrm{P}, \mathrm{mg} / \mathrm{L}$ & 0.38 & 0.24 & 0.22 & 0.35 & 0.49 & 38 & 0 & 0.07 & 0.98 & -- \\
\hline Carbon, dissolved, organic as $\mathrm{C}, \mathrm{mg} / \mathrm{L}$ & 6.7 & 3.0 & 4.8 & 6.1 & 7.5 & 38 & 0 & 2.9 & 18.6 & -- \\
\hline Escherichia coli, MPN/100 mL & 5,380 & 5,620 & -- & 5,380 & -- & 4 & 0 & 20 & 11,000 & -- \\
\hline Fecal coliform, MPN/100 mL & 6,180 & 6,200 & -- & 6,180 & -- & 4 & 0 & 20 & 12,000 & -- \\
\hline Copper, dissolved, $\mu \mathrm{g} / \mathrm{L}$ & 2.1 & 0.8 & 1.6 & 1.9 & 2.6 & 38 & 0 & 1.1 & 4.6 & -- \\
\hline Copper, total recoverable, $\mu \mathrm{g} / \mathrm{L}$ & 11 & 7.9 & 5.4 & 11 & 14 & 36 & 0 & 2.9 & 34 & -- \\
\hline Lead, dissolved, $\mu \mathrm{g} / \mathrm{L}$ & 0.08 & 0.06 & 0.04 & 0.06 & 0.07 & 38 & 6 & 0.03 & 0.27 & $0.04,0.06$ \\
\hline Lead, total recoverable, $\mu \mathrm{g} / \mathrm{L}$ & 8.3 & 7.2 & 2.6 & 7.4 & 10.3 & 36 & 0 & 0.62 & 26.9 & -- \\
\hline Manganese, dissolved, $\mu \mathrm{g} / \mathrm{L}$ & 19.5 & 26.0 & 6.4 & 11.6 & 20.6 & 38 & 0 & 0.2 & 119 & -- \\
\hline Manganese, total recoverable, $\mu \mathrm{g} / \mathrm{L}$ & 304 & 242 & 143 & 263 & 379 & 36 & 0 & 42.2 & 884 & -- \\
\hline Zinc, dissolved, $\mu \mathrm{g} / \mathrm{L}$ & 5.3 & 3.0 & 2.8 & 4.8 & 6.9 & 38 & 0 & 1.8 & 13.6 & -- \\
\hline Zinc, total recoverable, $\mu \mathrm{g} / \mathrm{L}$ & 40 & 29 & 19 & 34 & 53 & 36 & 0 & 7 & 134 & -- \\
\hline
\end{tabular}


Table 4. Statistics for concentrations and measurement values at stormwater sampling sites, 2006-2010._Continued

$\left[\mathrm{ft}^{3} / \mathrm{s}\right.$, cubic foot per second; $\mathrm{mL}$, milliliter; $\mu \mathrm{S} / \mathrm{cm}$, microsiemens per centimeter at 25 degrees Celsius; $\mathrm{CaCO}_{3}$, calcium carbonate; $\mathrm{mg} / \mathrm{L}$, milligrams per liter; $\mu \mathrm{g} / \mathrm{L}$, micrograms per liter; $\mathrm{N}$, nitrogen; $\mathrm{P}$, phosphorus; $\mathrm{C}$, carbon; SD, standard deviation; $\mathrm{n}$, number of samples; nlt, number of "less thans" or censored data; --, not calculated; \%, percentile; MPN, most probable number]

\begin{tabular}{|c|c|c|c|c|c|c|c|c|c|c|}
\hline \multirow{2}{*}{$\begin{array}{l}\text { Property or } \\
\text { constituent }\end{array}$} & \multicolumn{5}{|c|}{ Summary statistics } & \multirow{2}{*}{ n } & \multirow{2}{*}{ nlt } & \multicolumn{2}{|c|}{$\begin{array}{l}\text { Range of uncensored } \\
\text { values }\end{array}$} & \multirow{2}{*}{$\begin{array}{c}\text { Censoring } \\
\text { level }\end{array}$} \\
\hline & Mean & SD & $25 \%$ & $\begin{array}{l}\text { Median } \\
50 \%\end{array}$ & $75 \%$ & & & Minimum & Maximum & \\
\hline & \multicolumn{10}{|c|}{06714000 South Platte River at Denver, Colorado } \\
\hline Streamflow, mean, $\mathrm{ft}^{3} / \mathrm{s}$ & 1,480 & 1,370 & 656. & 1,090 & 1,790 & 49 & 0 & 184 & 8,083 & -- \\
\hline Streamflow, volume, acre-feet & 1,410 & 1,280 & 667 & 1,010 & 1,630 & 49 & 0 & 168 & 7,350 & -- \\
\hline $\mathrm{pH}$, standard units & 7.5 & 0.3 & 7.5 & 7.5 & 7.7 & 48 & 0 & 6.6 & 8.0 & -- \\
\hline Specific conductance, $\mu \mathrm{S} / \mathrm{cm}$ & 522 & 225 & 384 & 491 & 597 & 46 & 0 & 260 & 1,390 & -- \\
\hline Hardness, total, $\mathrm{mg} / \mathrm{L}$ as $\mathrm{CaCO}_{3}$ & 141 & 43 & 108 & 138 & 160 & 48 & 0 & 74.4 & 251 & -- \\
\hline Calcium, $\mathrm{mg} / \mathrm{L}$ & 42 & 12 & 32 & 42 & 49 & 48 & 0 & 22 & 76 & -- \\
\hline Magnesium, mg/L & 8.6 & 3.1 & 6.2 & 8 & 9.8 & 48 & 0 & 4.3 & 18 & -- \\
\hline $\begin{array}{l}\text { Suspended solids, residue on evaporation } \\
\text { at } 105^{\circ} \mathrm{C}, \mathrm{mg} / \mathrm{L} \\
\text { Nitrogen, total, ammonia plus organic as }\end{array}$ & 202 & 125 & 122 & 180 & 258 & 47 & 0 & 20.0 & 660 & -- \\
\hline $\mathrm{N}, \mathrm{mg} / \mathrm{L}$ & 1.8 & 0.82 & 1.2 & 1.5 & 2.2 & 7 & 0 & 0.51 & 4.2 & -- \\
\hline Nitrogen, dissolved, ammonia as $\mathrm{N}, \mathrm{mg} / \mathrm{L}$ & 0.12 & 0.13 & 0.03 & 0.07 & 0.13 & 47 & 4 & 0.01 & 0.60 & 0.01 \\
\hline Nitrogen, dissolved, nitrite plus nitrate as & & & & & & & & & & -- \\
\hline $\mathrm{N}, \mathrm{mg} / \mathrm{L}$ & 1.21 & 0.65 & 0.80 & 0.98 & 1.38 & 46 & 0 & 0.55 & 3.69 & \\
\hline Orthophosphate, dissolved as $\mathrm{P}, \mathrm{mg} / \mathrm{L}$ & 0.150 & 0.087 & 0.098 & 0.122 & 0.167 & 47 & 0 & 0.046 & 0.487 & -- \\
\hline Phosphorus, total as $\mathrm{P}, \mathrm{mg} / \mathrm{L}$ & 0.54 & 0.24 & 0.39 & 0.47 & 0.65 & 47 & 0 & 0.14 & 1.33 & -- \\
\hline Carbon, dissolved, organic as $\mathrm{C}, \mathrm{mg} / \mathrm{L}$ & 6.3 & 2.0 & 5.0 & 5.8 & 7.2 & 48 & 0 & 4.1 & 12.2 & -- \\
\hline Escherichia coli, MPN/100 mL & 8,900 & 9,926 & -- & 6,250 & -- & 4 & 0 & 110 & 23,000 & -- \\
\hline Fecal coliform, MPN/100 mL & 10,520 & 9,486 & -- & 9,450 & -- & 4 & 0 & 170 & 23,000 & -- \\
\hline Copper, dissolved, $\mu \mathrm{g} / \mathrm{L}$ & 2.9 & 1.2 & 2.2 & 2.5 & 3.3 & 48 & 1 & 1.5 & 7.0 & 1 \\
\hline Copper, total recoverable, $\mu \mathrm{g} / \mathrm{L}$ & 17 & 11 & 9.1 & 15 & 21 & 45 & 0 & 3.8 & 67 & -- \\
\hline Lead, dissolved, $\mu \mathrm{g} / \mathrm{L}$ & 0.118 & 0.062 & 0.075 & 0.1 & 0.155 & 48 & 0 & 0.04 & 0.31 & -- \\
\hline Lead, total recoverable, $\mu \mathrm{g} / \mathrm{L}$ & 15.2 & 13.7 & 6.72 & 13.1 & 18 & 45 & 0 & 2.13 & 79.5 & -- \\
\hline Manganese, dissolved, $\mu \mathrm{g} / \mathrm{L}$ & 11 & 25 & 1.1 & 3.3 & 9.7 & 48 & 0 & 0.1 & 156 & -- \\
\hline Manganese, total recoverable, $\mu \mathrm{g} / \mathrm{L}$ & 333 & 182 & 215 & 288 & 412 & 45 & 0 & 77.9 & 873 & -- \\
\hline Zinc, dissolved, $\mu \mathrm{g} / \mathrm{L}$ & 8.3 & 4.5 & 5.0 & 6.8 & 10.6 & 48 & 0 & 3.3 & 21.3 & -- \\
\hline Zinc, total recoverable, $\mu \mathrm{g} / \mathrm{L}$ & 71 & 51 & 33 & 60 & 91 & 45 & 0 & 13 & 287 & -- \\
\hline
\end{tabular}


Table 4. Statistics for concentrations and measurement values at stormwater sampling sites, 2006-2010._Continued

$\left[\mathrm{ft}^{3} / \mathrm{s}\right.$, cubic foot per second; $\mathrm{mL}$, milliliter; $\mu \mathrm{S} / \mathrm{cm}$, microsiemens per centimeter at 25 degrees Celsius; $\mathrm{CaCO}_{3}$, calcium carbonate; $\mathrm{mg} / \mathrm{L}$, milligrams per liter; $\mu \mathrm{g} / \mathrm{L}$, micrograms per liter; $\mathrm{N}$, nitrogen; $\mathrm{P}$, phosphorus; $\mathrm{C}$, carbon; SD, standard deviation; $\mathrm{n}$, number of samples; nlt, number of "less thans" or censored data; --, not calculated; \%, percentile; MPN, most probable number]

\begin{tabular}{|c|c|c|c|c|c|c|c|c|c|c|}
\hline \multirow{2}{*}{$\begin{array}{l}\text { Property or } \\
\text { constituent }\end{array}$} & \multicolumn{5}{|c|}{ Summary statistics } & \multirow{2}{*}{$\mathbf{n}$} & \multirow{2}{*}{ nlt } & \multicolumn{2}{|c|}{$\begin{array}{l}\text { Range of uncensored } \\
\text { values }\end{array}$} & \multirow{2}{*}{$\begin{array}{l}\text { Censoring } \\
\text { level }\end{array}$} \\
\hline & Mean & SD & $25 \%$ & $\begin{array}{l}\text { Median } \\
50 \%\end{array}$ & $75 \%$ & & & Minimum & Maximum & \\
\hline & \multicolumn{10}{|c|}{394329104490101 Toll Gate Creek above 6th Avenue near Aurora, Colorado } \\
\hline Streamflow, mean, $\mathrm{ft}^{3} / \mathrm{s}$ & 261 & 289 & 73 & 182 & 345 & 30 & 0 & 4 & 1,400 & -- \\
\hline Streamflow, volume, acre-feet & 242 & 241 & 67 & 156 & 313 & 30 & 0 & 4 & 921 & -- \\
\hline $\mathrm{pH}$, standard units & 7.7 & 0.2 & 7.5 & 7.6 & 7.8 & 33 & 0 & 7.4 & 8.0 & -- \\
\hline Specific conductance, $\mu \mathrm{S} / \mathrm{cm}$ & 1,112 & 506 & 720 & 957 & 1,500 & 31 & 0 & 363 & 2,230 & -- \\
\hline Hardness, total, $\mathrm{mg} / \mathrm{L}$ as $\mathrm{CaCO}_{3}$ & 316 & 167 & 193 & 251 & 418 & 33 & 0 & 84.6 & 746 & -- \\
\hline Calcium, mg/L & 95 & 50 & 60 & 77 & 129 & 33 & 0 & 26 & 226 & -- \\
\hline Magnesium, mg/L & 19 & 10 & 11 & 15 & 24 & 33 & 0 & 4.6 & 44 & -- \\
\hline $\begin{array}{l}\text { Suspended solids, residue on evaporation } \\
\text { at } 105^{\circ} \mathrm{C}, \mathrm{mg} / \mathrm{L} \\
\text { Nitrogen, total, ammonia plus organic as }\end{array}$ & 180 & 186 & 46 & 97 & 254 & 31 & 0 & 10 & 695 & -- \\
\hline $\mathrm{N}, \mathrm{mg} / \mathrm{L}$ & 1.6 & 0.78 & 1.1 & 1.4 & 2.0 & 32 & 0 & 0.63 & 3.5 & -- \\
\hline $\begin{array}{l}\text { Nitrogen, dissolved, ammonia as } \mathrm{N}, \mathrm{mg} / \mathrm{L} \\
\text { Nitrogen, dissolved, nitrite plus nitrate as }\end{array}$ & 0.14 & 0.15 & 0.04 & 0.09 & 0.20 & 32 & 3 & 0.01 & 0.66 & 0.01 \\
\hline $\mathrm{N}, \mathrm{mg} / \mathrm{L}$ & 0.64 & 0.21 & 0.49 & 0.59 & 0.77 & 32 & 0 & 0.36 & 1.28 & -- \\
\hline Orthophosphate, dissolved as $\mathrm{P}, \mathrm{mg} / \mathrm{L}$ & 0.022 & 0.020 & 0.007 & 0.013 & 0.035 & 32 & 1 & 0.003 & 0.077 & 0.003 \\
\hline Phosphorus, total as $\mathrm{P}, \mathrm{mg} / \mathrm{L}$ & 0.33 & 0.32 & 0.12 & 0.22 & 0.44 & 32 & 0 & 0.04 & 1.38 & -- \\
\hline Carbon, dissolved, organic as $\mathrm{C}, \mathrm{mg} / \mathrm{L}$ & 10.4 & 3.7 & 8.5 & 10.4 & 11.7 & 33 & 0 & 5.3 & 20.9 & -- \\
\hline Escherichia coli, MPN/100 mL & 2,310 & 1,715 & -- & 3,300 & -- & 3 & 0 & 330 & 3,300 & -- \\
\hline Fecal coliform, MPN/100 mL & 2,310 & 1,715 & -- & 3,300 & -- & 3 & 0 & 330 & 3,300 & -- \\
\hline Copper, dissolved, $\mu \mathrm{g} / \mathrm{L}$ & 2.5 & 1.1 & 1.8 & 2.2 & 2.8 & 33 & 0 & 1.0 & 4.9 & -- \\
\hline Copper, total recoverable, $\mu \mathrm{g} / \mathrm{L}$ & 12 & 8.8 & 5.8 & 8.3 & 15 & 33 & 0 & 2.9 & 33 & -- \\
\hline Lead, dissolved, $\mu \mathrm{g} / \mathrm{L}$ & 0.097 & 0.07 & 0.053 & 0.08 & 0.12 & 33 & 4 & 0.04 & 0.34 & $0.04,0.06$ \\
\hline Lead, total recoverable, $\mu \mathrm{g} / \mathrm{L}$ & 7.18 & 7.67 & 2.35 & 3.45 & 9.18 & 33 & 0 & 0.71 & 28.3 & -- \\
\hline Manganese, dissolved, $\mu \mathrm{g} / \mathrm{L}$ & 75.29 & 78.83 & 20.3 & 50.9 & 105 & 33 & 0 & 2.8 & 330 & -- \\
\hline Manganese, total recoverable, $\mu \mathrm{g} / \mathrm{L}$ & 381 & 269 & 192 & 244 & 480 & 33 & 0 & 103 & 1,120 & -- \\
\hline Zinc, dissolved, $\mu \mathrm{g} / \mathrm{L}$ & 8.8 & 5.4 & 4.7 & 8.0 & 11 & 33 & 0 & 1.5 & 26.1 & -- \\
\hline Zinc, total recoverable, $\mu \mathrm{g} / \mathrm{L}$ & 47 & 35 & 24 & 33 & 59 & 33 & 0 & 9 & 132 & -- \\
\hline
\end{tabular}


Table 4. Statistics for concentrations and measurement values at stormwater sampling sites, 2006-2010._Continued

$\left[\mathrm{ft}^{3} / \mathrm{s}\right.$, cubic foot per second; $\mathrm{mL}$, milliliter; $\mu \mathrm{S} / \mathrm{cm}$, microsiemens per centimeter at 25 degrees Celsius; $\mathrm{CaCO}_{3}$, calcium carbonate; $\mathrm{mg} / \mathrm{L}$, milligrams per liter; $\mu \mathrm{g} / \mathrm{L}$, micrograms per liter; $\mathrm{N}$, nitrogen; $\mathrm{P}$, phosphorus; $\mathrm{C}$, carbon; SD, standard deviation; $\mathrm{n}$, number of samples; nlt, number of "less thans" or censored data; --, not calculated; \%, percentile; MPN, most probable number]

\begin{tabular}{|c|c|c|c|c|c|c|c|c|c|c|}
\hline \multirow{2}{*}{$\begin{array}{l}\text { Property or } \\
\text { constituent }\end{array}$} & \multicolumn{5}{|c|}{ Summary statistics } & \multirow{2}{*}{ n } & \multirow{2}{*}{ nlt } & \multicolumn{2}{|c|}{$\begin{array}{l}\text { Range of uncensored } \\
\text { values }\end{array}$} & \multirow{2}{*}{$\begin{array}{l}\text { Censoring } \\
\text { level }\end{array}$} \\
\hline & Mean & SD & $25 \%$ & $\begin{array}{l}\text { Median } \\
50 \% \\
\end{array}$ & $75 \%$ & & & Minimum & $\overline{\text { Maximum }}$ & \\
\hline & \multicolumn{10}{|c|}{394839104570300 Sand Creek at mouth near Commerce City, Colorado } \\
\hline Streamflow, mean, $\mathrm{ft}^{3} / \mathrm{s}$ & 285 & 275 & 100 & 229 & 374 & 47 & 0 & 21 & 1,620 & -- \\
\hline Streamflow, volume, acre-feet & 255 & 249 & 95 & 205 & 348 & 47 & 0 & 19 & 1,473 & -- \\
\hline $\mathrm{pH}$, standard units & 7.6 & 0.2 & 7.4 & 7.6 & 7.8 & 47 & 0 & 7.3 & 8.0 & -- \\
\hline Specific conductance, $\mu \mathrm{S} / \mathrm{cm}$ & 811 & 392 & 575 & 684 & 908 & 45 & 0 & 330 & 2,020 & -- \\
\hline Hardness, total, $\mathrm{mg} / \mathrm{L}$ as $\mathrm{CaCO}_{3}$ & 195 & 79 & 153 & 171 & 210 & 47 & 0 & 74.8 & 455 & -- \\
\hline Calcium, mg/L & 59 & 22 & 47 & 52 & 64 & 47 & 0 & 23 & 131 & -- \\
\hline Magnesium, mg/L & 12 & 5.6 & 8.4 & 10 & 13 & 47 & 0 & 4.1 & 31 & -- \\
\hline $\begin{array}{l}\text { Suspended solids, residue on evaporation } \\
\text { at } 105^{\circ} \mathrm{C}, \mathrm{mg} / \mathrm{L} \\
\text { Nitrogen, total, ammonia plus organic as }\end{array}$ & 351 & 306 & 128 & 236 & 470 & 47 & 0 & 56.0 & 1,360 & -- \\
\hline $\mathrm{N}, \mathrm{mg} / \mathrm{L}$ & 2.6 & 1.6 & 1.6 & 2.0 & 3.2 & 45 & 0 & 1.1 & 9.5 & -- \\
\hline Nitrogen, dissolved, ammonia as $\mathrm{N}, \mathrm{mg} / \mathrm{L}$ & 0.11 & 0.11 & 0.02 & 0.09 & 0.18 & 45 & 8 & 0.01 & 0.47 & $\begin{array}{c}0.005,0.01 \\
0.02\end{array}$ \\
\hline $\begin{array}{l}\text { Nitrogen, dissolved, nitrite plus nitrate as } \\
\mathrm{N}, \mathrm{mg} / \mathrm{L}\end{array}$ & 0.88 & 0.43 & 0.59 & 0.78 & 0.95 & 45 & 0 & 0.41 & 2.55 & -- \\
\hline Orthophosphate, dissolved as $\mathrm{P}, \mathrm{mg} / \mathrm{L}$ & 0.121 & 0.113 & 0.059 & 0.089 & 0.141 & 45 & 0 & 0.017 & 0.627 & -- \\
\hline Phosphorus, total as $\mathrm{P}, \mathrm{mg} / \mathrm{L}$ & 0.79 & 0.47 & 0.49 & 0.63 & 0.90 & 45 & 0 & 0.27 & 2.36 & -- \\
\hline Carbon, dissolved, organic as $\mathrm{C}, \mathrm{mg} / \mathrm{L}$ & 10.8 & 4.2 & 7.8 & 9.3 & 13.2 & 46 & 0 & 5.8 & 23.6 & -- \\
\hline Escherichia coli, MPN/100 mL & 3,530 & 2,370 & -- & 2,950 & -- & 3 & 0 & 790 & 4,900 & -- \\
\hline Fecal coliform, MPN/100 mL & 2,630 & 2,090 & -- & 2,140 & -- & 3 & 0 & 790 & 4,900 & -- \\
\hline Copper, dissolved, $\mu \mathrm{g} / \mathrm{L}$ & 3.0 & 2.0 & 1.6 & 2.4 & 3.6 & 47 & 0 & 1.2 & 12.5 & -- \\
\hline Copper, total recoverable, $\mu \mathrm{g} / \mathrm{L}$ & 22 & 14 & 11 & 17 & 28 & 47 & 0 & 6.5 & 55 & -- \\
\hline Lead, dissolved, $\mu \mathrm{g} / \mathrm{L}$ & 0.19 & 0.14 & 0.10 & 0.14 & 0.25 & 47 & 0 & 0.04 & 0.74 & -- \\
\hline Lead, total recoverable, $\mu \mathrm{g} / \mathrm{L}$ & 21.0 & 17.3 & 6.16 & 14.5 & 31.6 & 47 & 0 & 3.67 & 60.5 & -- \\
\hline Manganese, dissolved, $\mu \mathrm{g} / \mathrm{L}$ & 45 & 78 & 2.5 & 11 & 59 & 47 & 0 & 0.5 & 391 & -- \\
\hline Manganese, total recoverable, $\mu \mathrm{g} / \mathrm{L}$ & 678 & 661 & 283 & 466 & 640 & 47 & 0 & 144 & 3,210 & -- \\
\hline Zinc, dissolved, $\mu \mathrm{g} / \mathrm{L}$ & 67.2 & 191 & 7.8 & 10.9 & 21.0 & 47 & 0 & 2.8 & 1,170 & -- \\
\hline Zinc, total recoverable, $\mu \mathrm{g} / \mathrm{L}$ & 524 & 1205.4 & 44 & 75 & 241 & 47 & 0 & 22 & 5,230 & -- \\
\hline
\end{tabular}


Table 4. Statistics for concentrations and measurement values at stormwater sampling sites, 2006-2010._Continued

$\left[\mathrm{ft}^{3} / \mathrm{s}\right.$, cubic foot per second; $\mathrm{mL}$, milliliter; $\mu \mathrm{S} / \mathrm{cm}$, microsiemens per centimeter at 25 degrees Celsius; $\mathrm{CaCO}_{3}$, calcium carbonate; $\mathrm{mg} / \mathrm{L}$, milligrams per liter; $\mu \mathrm{g} / \mathrm{L}$, micrograms per liter; $\mathrm{N}$, nitrogen; $\mathrm{P}$, phosphorus; $\mathrm{C}$, carbon; SD, standard deviation; $\mathrm{n}$, number of samples; nlt, number of "less thans" or censored data; --, not calculated; \%, percentile; MPN, most probable number]

\begin{tabular}{|c|c|c|c|c|c|c|c|c|c|c|}
\hline \multirow{2}{*}{$\begin{array}{l}\text { Property or } \\
\text { constituent }\end{array}$} & \multicolumn{5}{|c|}{ Summary statistics } & \multirow{2}{*}{$\mathbf{n}$} & \multirow{2}{*}{ nlt } & \multicolumn{2}{|c|}{$\begin{array}{l}\text { Range of uncensored } \\
\text { values }\end{array}$} & \multirow{2}{*}{$\begin{array}{l}\text { Censoring } \\
\text { level }\end{array}$} \\
\hline & Mean & SD & $25 \%$ & $\begin{array}{l}\text { Median } \\
50 \% \\
\end{array}$ & $75 \%$ & & & Minimum & Maximum & \\
\hline & \multicolumn{10}{|c|}{06720500 South Platte River at Henderson, Colorado } \\
\hline Streamflow, mean, $\mathrm{ft}^{3} / \mathrm{s}$ & 2,260 & 3,290 & 754 & 1,470 & 2,390 & 33 & 0 & 218 & 19,000 & -- \\
\hline Streamflow, volume, acre-feet & 1,720 & 1,570 & 663 & 1,340 & 2,040 & 33 & 0 & 198 & 6,920 & -- \\
\hline $\mathrm{pH}$, standard units & 7.3 & 0.2 & 7.2 & 7.4 & 7.5 & 34 & 0 & 6.6 & 7.7 & -- \\
\hline Specific conductance, $\mu \mathrm{S} / \mathrm{cm}$ & 557 & 196 & 454 & 528 & 601 & 34 & 0 & 205 & 1,260 & -- \\
\hline Hardness, total, $\mathrm{mg} / \mathrm{L}$ as $\mathrm{CaCO}_{3}$ & 141 & 31 & 119 & 133 & 154 & 34 & 0 & 95 & 226 & -- \\
\hline Calcium, mg/L & 42 & 9 & 36 & 41 & 47 & 34 & 0 & 28 & 64 & -- \\
\hline Magnesium, mg/L & 8.9 & 2.5 & 7.3 & 8.3 & 10 & 34 & 0 & 6.0 & 17 & -- \\
\hline $\begin{array}{l}\text { Suspended solids, residue on evaporation } \\
\text { at } 105^{\circ} \mathrm{C}, \mathrm{mg} / \mathrm{L} \\
\text { Nitrogen, total, ammonia plus organic as }\end{array}$ & 174 & 112 & 94 & 133 & 242 & 32 & 0 & 44 & 545 & -- \\
\hline $\mathrm{N}, \mathrm{mg} / \mathrm{L}$ & 2.9 & 1.7 & 2.0 & 2.6 & 3.4 & 3 & 0 & 0.96 & 9.4 & -- \\
\hline $\begin{array}{l}\text { Nitrogen, dissolved, ammonia as } \mathrm{N}, \mathrm{mg} / \mathrm{L} \\
\text { Nitrogen, dissolved, nitrite plus nitrate as }\end{array}$ & 0.80 & 0.88 & 0.24 & 0.58 & 0.73 & 33 & 1 & 0.11 & 3.38 & 0.01 \\
\hline $\mathrm{N}, \mathrm{mg} / \mathrm{L}$ & 2.08 & 0.81 & 1.53 & 1.87 & 2.24 & 33 & 0 & 0.96 & 4.64 & -- \\
\hline Orthophosphate, dissolved as $\mathrm{P}, \mathrm{mg} / \mathrm{L}$ & 0.461 & 0.279 & 0.262 & 0.367 & 0.621 & 33 & 0 & 0.152 & 1.15 & -- \\
\hline Phosphorus, total as $\mathrm{P}, \mathrm{mg} / \mathrm{L}$ & 1.02 & 0.46 & 0.72 & 0.96 & 1.18 & 33 & 0 & 0.37 & 2.85 & -- \\
\hline Carbon, dissolved, organic as $\mathrm{C}, \mathrm{mg} / \mathrm{L}$ & 9.1 & 5.3 & 6.2 & 7.5 & 10.6 & 34 & 0 & 4.8 & 34.4 & -- \\
\hline Escherichia coli, MPN/100 mL & 10,400 & 11,550 & -- & 7,900 & -- & 3 & 0 & 310 & 23,000 & -- \\
\hline Fecal coliform, MPN/100 mL & 12,100 & 11,370 & -- & 13,000 & -- & 3 & 0 & 310 & 23,000 & -- \\
\hline Copper, dissolved, $\mu \mathrm{g} / \mathrm{L}$ & 3.04 & 0.92 & 2.4 & 2.75 & 3.4 & 34 & 0 & 1.7 & 5.5 & -- \\
\hline Copper, total recoverable, $\mu \mathrm{g} / \mathrm{L}$ & 24 & 13 & 13 & 22 & 28 & 32 & 0 & 9.1 & 63 & -- \\
\hline Lead, dissolved, $\mu \mathrm{g} / \mathrm{L}$ & 0.22 & 0.08 & 0.17 & 0.21 & 0.29 & 34 & 0 & 0.07 & 0.41 & -- \\
\hline Lead, total recoverable, $\mu \mathrm{g} / \mathrm{L}$ & 22.6 & 15.9 & 10.2 & 17.3 & 32.4 & 32 & 0 & 5.09 & 70.9 & -- \\
\hline Manganese, dissolved, $\mu \mathrm{g} / \mathrm{L}$ & 62 & 127 & 18 & 33 & 62 & 34 & 0 & 0.6 & 757 & -- \\
\hline Manganese, total recoverable, $\mu \mathrm{g} / \mathrm{L}$ & 408 & 305 & 243 & 359 & 472 & 32 & 0 & 138 & 1,840 & -- \\
\hline Zinc, dissolved, $\mu \mathrm{g} / \mathrm{L}$ & 18.3 & 7.5 & 13.1 & 17.3 & 22.1 & 34 & 0 & 6.7 & 45.8 & -- \\
\hline Zinc, total recoverable, $\mu \mathrm{g} / \mathrm{L}$ & 114 & 68 & 68 & 91 & 148 & 32 & 0 & 32 & 308 & -- \\
\hline
\end{tabular}


For statistical summaries and boxplots, the number of censored values in the data are considered in the computations, but the values of statistics (in the tables and boxplots) that are affected by the presence of censored data (such as mean, standard deviation, and the lower percentiles) are predicted based on log-probability regression on the uncensored values (Helsel and Hirsch, 1992). If more than 25 percent of the data are censored, statistics were not computed for the types affected by censored values. In this report, generally only the 25 th percentile and the mean statistics on a few water-quality constituents required the log-probability regression methods. For Mann-Whitney rank sum testing in this report, no groups of water-quality constituents for a period had more than 50-percent censored values, which is the limit for successful use of the test to determine differences (Helsel and Hirsch, 1992).

\section{Stormwater Samples}

About 200 stormwater samples were collected by using refrigerated, automatic pumping samplers that were manually activated when stormwater runoff began. Once activated, the samplers obtained aliquots, or sample portions, by withdrawing fixed volumes of water from the stream every 60 minutes. The samplers were equipped with eight 2-liter (L) bottles and were programmed to add three aliquots to each bottle. Time-weighted composite stormwater samples were collected by compositing individual aliquots of stormwater that were obtained at fixed-time increments typically during 12-hour intervals; bacteriological samples were collected manually from streams during some storms (see Bacteriological Samples section). Each station was visited by USGS project staff every 12 to 24 hours during storm events. As the stations were visited, the contents of four sequential bottles were composited into a single time-weighted composite sample covering about 12 hours of the storm hydrograph, and individual sample bottles were filled by using a churn splitter for subsequent laboratory analysis. The churn splitter is a plastic container for compositing samples that allows mixing of raw sample water while bottles are filled using a spigot on the churn (U.S. Geological Survey, variously dated). The compositing, filtration, bottling, and preservation of samples submitted to NWQL took place in the field using procedures described in the USGS National Field Manual (U.S. Geological Survey, variously dated). If individual sample bottles were found to contain different volumes of water, it was assumed that individual aliquot volumes varied, and the aliquot sample volumes were adjusted, if possible, or the samples were discarded. The samples were analyzed by the NWQL for physical properties such as $\mathrm{pH}$, specific conductance, hardness, and residue on evaporation at $105^{\circ} \mathrm{C}$; for major ions such as calcium and magnesium, and organic carbon, and nutrients including ammonia, total ammonia plus organic nitrogen, dissolved nitrite plus nitrate, orthophosphate, and total phosphorus; and for metals, including total recoverable and dissolved phases of copper, lead, manganese, and zinc (table 4).

The composite samples integrate concentrations over time and are appropriate for evaluating water-quality criteria developed for aquatic life (Colorado Department of Public Health and Environment, 2011a, 2011b). Generally, the most stringent criteria in place are the acute standards, which specify a maximum allowable concentration for a period of time, usually 24 hours. The acute criteria, like the composite samples, describe concentration over a period of time.

Decisions to activate samplers in this study were made by USGS project staff on the basis of local weather and streamflow conditions, which were monitored continuously through a variety of sources, including data available in near real-time from the World Wide Web (http://alert.udfcd.org/). The ALERT system, operated by UDFCD, provides data in near real-time from an extensive network of precipitation gages and information from many UDFCD streamflowgaging stations (Urban Drainage and Flood Control District, 2012). It also integrates streamflow 
data from USGS and CODWR streamflow-gaging stations into Web-based reports in near realtime. The ALERT data typically are available within a few minutes of measurement.

Boxplots were constructed for values and concentrations at all sites. The data from each site are displayed side-by-side for selected water-quality measurements and constituents. The explanation for the boxplots is shown in figure 2. The boxplot shows the quartiles (25th, 50th or median, and 75th percentiles). The whiskers on the boxplot extend to the maximum and minimum values. An open circle is plotted for the mean value. The number of values used in the boxplot, the number of values that were censored, and the highest censoring level that was applied to the data for a particular boxplot are shown at the top of the boxplot. A line representing one-half of the censoring level, essentially the long-term method detection level, is drawn on the boxplot corresponding to the y-axis value of that long-term method detection level. Any boxplot that has a censoring level greater than the 25th percentile is drawn with a dashed line for the box below that level. The dashed box indicates that statistical methods were used to estimate the 25 th percentile (same as methods used to compute the statistics for this report). Boxplots provide a visual representation of basic site statistics and are useful for interpreting differences among the 19982001, 2002-2005, and 2006-2010 periods.

\section{EXPLANATION}

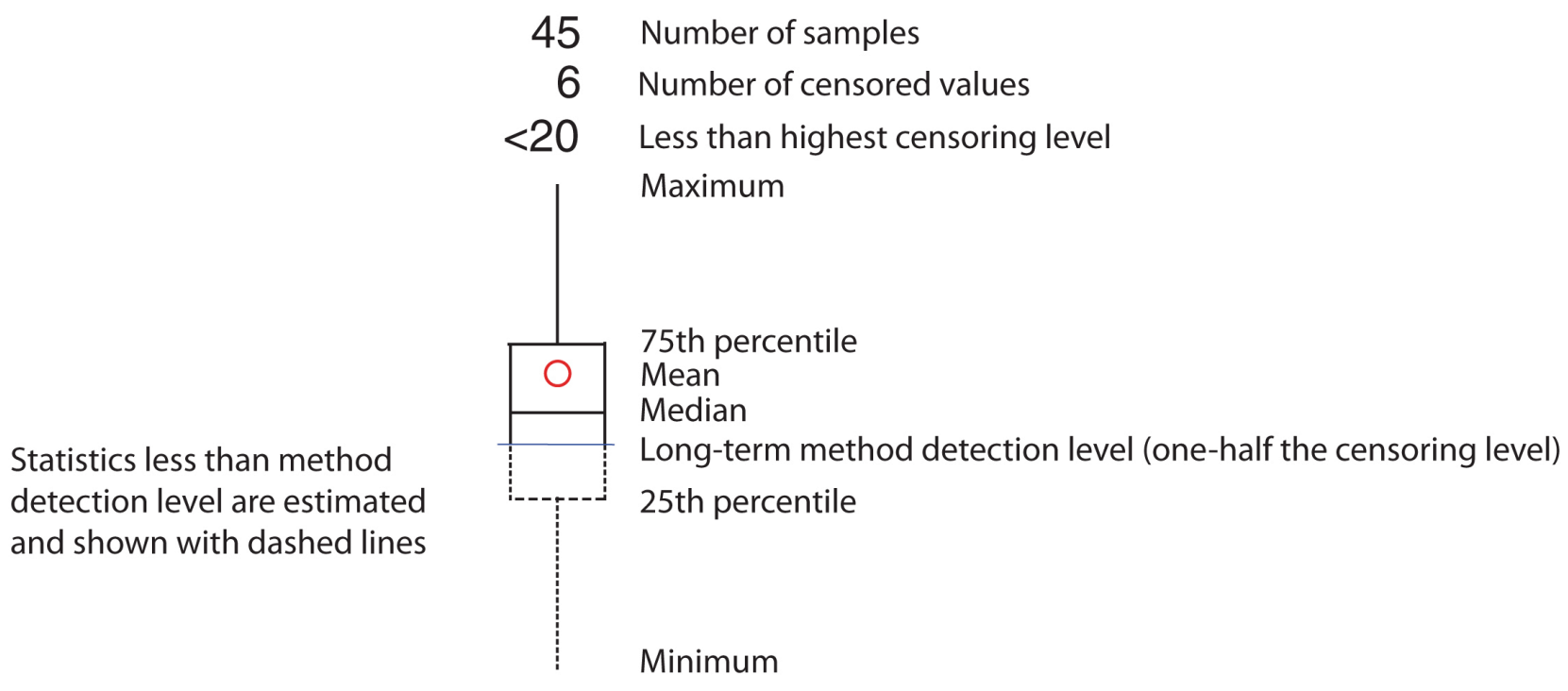

Figure 2. Explanation for boxplots shown in this report.

The Mann-Whitney rank-sum test (Iman and Conover, 1983) was used to test for statistically significant temporal differences in streamflow and water-quality data collected from the 2002-2005 and the 2006-2010 periods at the same monitoring station. The Mann-Whitney rank-sum test is a nonparametric procedure in which data for the two populations (data for both monitoring periods) are ranked; a two-sample t-test is then performed on the ranks of the data. The advantages of the Mann-Whitney rank-sum test over a simple two-sample t-test (Iman and Conover, 1983) are that (1) the data need not be normally distributed (and hydrologic data often are not normally distributed), and (2) the Mann-Whitney rank-sum test is less sensitive to the 
assumption of equal variances compared to other tests. The null hypothesis states that samples from both stations are from the same population; for example, the samples are not statistically different (Helsel and Hirsch, 1992). The Mann-Whitney rank-sum tests used in this report are two-tailed tests, and the probability of error ( $p$-value) was used in this report to determine the significance of statistical tests for all statistical methods. In this report, p-values less than 0.10 are considered to be statistically significant. The use of the word "significant" herein only applies to the p-value of the statistical test to reduce any confusion of descriptive terms. The median values for both periods tested are presented in a table with the p-values to provide the reader a frame of reference for the data periods. The test assesses the probability of the two datasets belonging to the same population, not necessarily just the difference in the medians.

\section{Bacteriological Samples}

A total of 17 bacteriological samples were collected during selected storms. The samples were collected manually as grab samples by filling bottles at the streambank and transporting them directly to MWRD for analysis, generally within an hour of sample collection. The bacteriological samples were analyzed for Escherichia coli and fecal coliform (table 4).

\section{Quality Assurance and Quality Control}

Quality-control (QC) samples (blanks and duplicates) were collected to characterize contamination and precision resulting from sampling equipment or ambient field conditions. Approximately 10 percent of all samples collected were QC samples. No blanks or duplicates were collected during 2006-2010 for bacteriological samples.

Blank samples were processed in the field using universal blank water (UBL), obtained from the NWQL and certified to have very low concentrations of inorganic and organic constituents. The UBL water was poured directly into autosampler bottles in the field, processed through churn splitters and filters, and transported to the NWQL for analysis. The results for blanks in table 5 indicate no substantial contamination to analyzed concentrations from ambient field conditions or from the use of sampling and processing equipment in the field or in the laboratory. 
Table 5. Analytical results for quality-assurance blanks, 2006-2010.

[SPRU, South Platte River below Union Avenue; SPRD, South Platte River at Denver; TGC6, Toll Gate Creek above 6th Avenue;

SCRM, Sand Creek at mouth near Commerce City; SPRH, South Platte River at Henderson; Samples consist of universal blank water

(UBL) passed through automated sampler bottles and all processing equipment; $\mu \mathrm{S} / \mathrm{cm}$ at $25^{\circ} \mathrm{C}$, microsiemens per centimeter at 25

degrees Celsius; ${ }^{\circ} \mathrm{C}$, Celsius; mg/L, milligrams per liter; $\mathrm{N}$, nitrogen; $\mathrm{P}$, phosphorus; $\mathrm{CaCO}$, calcium carbonate; $\mu \mathrm{g} / \mathrm{L}$, micrograms per

liter; E, estimated value less than reporting level; na, not applicable; $<$, less than]

\begin{tabular}{|c|c|c|c|c|c|c|c|c|c|c|c|c|c|}
\hline $\begin{array}{c}\text { Station name } \\
\text { Date (yyyymmdd) } \\
\text { Time (hhmm) }\end{array}$ & $\begin{array}{c}\text { SPRU } \\
20060709 \\
1432\end{array}$ & $\begin{array}{c}\text { TGC6 } \\
20070329 \\
0700\end{array}$ & $\begin{array}{c}\text { TGC6 } \\
20070425 \\
1340\end{array}$ & $\begin{array}{c}\text { SPRH } \\
20070516 \\
1415\end{array}$ & $\begin{array}{c}\text { SPRU } \\
20070530 \\
1220\end{array}$ & $\begin{array}{l}\text { SCRM } \\
20080806 \\
1030\end{array}$ & $\begin{array}{c}\text { SPRH } \\
20080808 \\
1100\end{array}$ & $\begin{array}{c}\text { SCRM } \\
20080810 \\
1111\end{array}$ & $\begin{array}{c}\text { SPRH } \\
20080913 \\
1245\end{array}$ & $\begin{array}{c}\text { SPRD } \\
20090418 \\
1630\end{array}$ & $\begin{array}{c}\text { SPRD } \\
20090527 \\
159\end{array}$ & $\begin{array}{c}\text { TGC6 } \\
200907202 \\
2256\end{array}$ & $\begin{array}{c}\text { SPRD } \\
20100704 \\
1900\end{array}$ \\
\hline $\mathrm{pH}$, in standard units & 7.6 & 6.0 & 8.2 & 7.8 & 8 & 8.5 & 7.9 & 8 & 8.1 & 6.2 & 8.1 & 7.2 & 7.9 \\
\hline $\begin{array}{l}\text { Specific conductance, } \\
\text { in } \mu \mathrm{S} / \mathrm{cm} \text { at } 25^{\circ} \mathrm{C}\end{array}$ & na & na & na & na & na & na & na & na & na & na & na & 1 & 1 \\
\hline $\begin{array}{l}\text { Hardness, total as } \\
\mathrm{CaCO}_{3} \text {, in } \mathrm{mg} / \mathrm{L}\end{array}$ & 1.09 & na & na & na & na & na & na & na & na & na & na & na & $<.18$ \\
\hline Calcium, in $\mathrm{mg} / \mathrm{L}$ & 0.41 & 0.04 & 0.05 & $<.02$ & 0.02 & E.03 & 0.09 & 0.04 & E.04 & 0.05 & 0.04 & $<.02$ & $<.04$ \\
\hline Magnesium, in mg/L & 0.014 & $<.014$ & $<.014$ & E.008 & $<.014$ & $<.020$ & $<.020$ & $<.020$ & $<.020$ & $<.012$ & $<.012$ & $<.012$ & $<.016$ \\
\hline $\begin{array}{l}\text { Residue on evapo- } \\
\text { ration at } 105^{\circ} \mathrm{C} \text {, in } \\
\mathrm{mg} / \mathrm{L}\end{array}$ & $<10$ & na & na & $<10$ & $<10$ & na & na & na & na & na & $<15$ & $<15$ & $<15$ \\
\hline $\begin{array}{l}\text { Nitrogen, Ammonia + } \\
\text { organic, total as } \mathrm{N} \text {, } \\
\text { in } \mathrm{mg} / \mathrm{L}\end{array}$ & $<.10$ & na & $<.10$ & $<.10$ & $<.10$ & $<.14$ & $<.14$ & $<.14$ & E. 10 & $<.10$ & Е.06 & $<.10$ & $<.10$ \\
\hline $\begin{array}{l}\text { Nitrogen, ammonia, } \\
\text { dissolved as } \mathrm{N} \text {, in } \\
\mathrm{mg} / \mathrm{L}\end{array}$ & E.008 & na & $<.020$ & $<.020$ & $<.020$ & $<.020$ & $<.020$ & $<.020$ & $<.020$ & $<.020$ & $<.020$ & $<.020$ & $<.020$ \\
\hline $\begin{array}{l}\text { Nitrogen, nitrite }+ \\
\text { nitrate, dissolved as } \\
\mathrm{N}, \text { in } \mathrm{mg} / \mathrm{L}\end{array}$ & $<.06$ & na & $<.06$ & $<.06$ & $<.06$ & $<.04$ & E.02 & $<.04$ & $<.04$ & $<.04$ & $<.04$ & $<.04$ & $<.04$ \\
\hline $\begin{array}{l}\text { Orthophosphate, } \\
\text { dissolved as } \mathrm{P} \text {, in } \\
\mathrm{mg} / \mathrm{L}\end{array}$ & E.003 & na & $<.006$ & E.003 & $<.006$ & E.003 & E.004 & E.003 & $<.006$ & $<.008$ & 0.017 & $<.008$ & $<.008$ \\
\hline $\begin{array}{l}\text { Phosphorus, total as } \\
\mathrm{P} \text {, in } \mathrm{mg} / \mathrm{L}\end{array}$ & $<.04$ & na & $<.04$ & $<.04$ & $<.04$ & E.02 & $<.04$ & $<.04$ & $<.04$ & $<.04$ & $<.04$ & $<.04$ & $<.04$ \\
\hline
\end{tabular}


Table 5. Analytical results for quality-assurance blanks, 2006-2010.-Continued

[SPRU, South Platte River below Union Avenue; SPRD, South Platte River at Denver; TGC6, Toll Gate Creek above 6th Avenue; SCRM, Sand Creek at mouth near Commerce City; SPRH, South Platte River at Henderson; Samples consist of universal blank water (UBL) passed through automated sampler bottles and all processing equipment; $\mu \mathrm{S} / \mathrm{cm}$ at $25^{\circ} \mathrm{C}$, microsiemens per centimeter at 25 degrees Celsius; ${ }^{\circ} \mathrm{C}$, Celsius; $\mathrm{mg} / \mathrm{L}$, milligrams per liter; $\mathrm{N}$, nitrogen; $\mathrm{P}$, phosphorus; $\mathrm{CaCO} 3$, calcium carbonate; $\mu \mathrm{g} / \mathrm{L}$, micrograms per liter; E, estimated value less than reporting level; na, not applicable; $<$, less than]

\begin{tabular}{|c|c|c|c|c|c|c|c|c|c|c|c|c|c|}
\hline $\begin{array}{c}\text { Station name } \\
\text { Date (yyyymmdd) } \\
\text { Time (hhmm) }\end{array}$ & $\begin{array}{c}\text { SPRU } \\
20060709 \\
1432\end{array}$ & $\begin{array}{c}\text { TGC6 } \\
20070329 \\
0700\end{array}$ & $\begin{array}{c}\text { TGC6 } \\
20070425 \\
1340\end{array}$ & $\begin{array}{c}\text { SPRH } \\
20070516 \\
1415\end{array}$ & $\begin{array}{c}\text { SPRU } \\
20070530 \\
1220\end{array}$ & $\begin{array}{c}\text { SCRM } \\
20080806 \\
1030\end{array}$ & $\begin{array}{c}\text { SPRH } \\
20080808 \\
1100\end{array}$ & $\begin{array}{c}\text { SCRM } \\
20080810 \\
1111\end{array}$ & $\begin{array}{c}\text { SPRH } \\
20080913 \\
1245\end{array}$ & $\begin{array}{c}\text { SPRD } \\
20090418 \\
1630\end{array}$ & $\begin{array}{c}\text { SPRD } \\
20090527 \\
159\end{array}$ & $\begin{array}{c}\text { TGC6 } \\
2009072020 \\
2256\end{array}$ & $\begin{array}{c}\text { SPRD } \\
20100704 \\
1900\end{array}$ \\
\hline $\begin{array}{l}\text { Carbon, organic, } \\
\text { dissolved as } \mathrm{C} \text {, in } \\
\mathrm{mg} / \mathrm{L}\end{array}$ & 0.8 & $<.4$ & 0.4 & E. 3 & $<.4$ & 0.5 & E. & E. 3 & na & E. 2 & $<.4$ & 0.5 & $<.7$ \\
\hline $\begin{array}{l}\text { Copper, dissolved, in } \\
\mu \mathrm{g} / \mathrm{L}\end{array}$ & $<.4$ & $<.40$ & $<.40$ & $<.40$ & $<.40$ & $<1$ & $<1$ & $<1.0$ & $<1.0$ & $<1.0$ & $<1.0$ & $<1.0$ & $<1.0$ \\
\hline $\begin{array}{l}\text { Copper, total } \\
\text { recoverable, in } \mu \mathrm{g} / \mathrm{L}\end{array}$ & $<.6$ & $<1.2$ & $<1.2$ & $<1.2$ & $<1.2$ & $<1.2$ & $<1$ & $<1.2$ & $<1.2$ & $<4.0$ & $<4.0$ & $<4.0$ & $<1.4$ \\
\hline $\begin{array}{l}\text { Lead, dissolved, in } \\
\mu \mathrm{g} / \mathrm{L}\end{array}$ & $<.08$ & $<.12$ & $<.12$ & $<.12$ & $<.12$ & $<.08$ & $<.0$ & $<.08$ & $<.08$ & $<.06$ & Е .05 & $<.06$ & $<.03$ \\
\hline $\begin{array}{l}\text { Lead, total } \\
\text { recoverable, in } \mu \mathrm{g} / \mathrm{L}\end{array}$ & E.05 & $<.06$ & $<.06$ & 0.07 & $<.06$ & 0.05 & E. 0 & E. 04 & $<.06$ & $<.10$ & 0.13 & $<.10$ & $<.06$ \\
\hline $\begin{array}{l}\text { Manganese, } \\
\text { dissolved, in } \mu \mathrm{g} / \mathrm{L}\end{array}$ & $<.2$ & $<.2$ & E.1 & $<.2$ & $<.2$ & $<.2$ & 2 & $<.2$ & $<.2$ & $<.2$ & 0.9 & $<.2$ & $<.3$ \\
\hline $\begin{array}{l}\text { Manganese, total } \\
\text { recoverable, in } \mu \mathrm{g} / \mathrm{L}\end{array}$ & 1.5 & $<.6$ & $<.6$ & E. 4 & $<.6$ & $<.8$ & E. & E.6 & E.6 & $<.4$ & 2.6 & $<.4$ & $<.8$ \\
\hline $\begin{array}{l}\text { Zinc, dissolved, in } \\
\mu \mathrm{g} / \mathrm{L}\end{array}$ & $<.6$ & 2.4 & $<.60$ & $<.60$ & 1.1 & $<1$ & $<1$. & $<1.8$ & $<1.8$ & E 1.8 & $<2.0$ & $<2.0$ & $<2.8$ \\
\hline $\begin{array}{l}\text { Zinc, total } \\
\text { recoverable, in } \mu \mathrm{g} / \mathrm{L}\end{array}$ & $<2$ & $<2$ & $<2.0$ & $<2.0$ & E1.0 & $<2$. & $<2$ & $<2.0$ & $<2.0$ & $<2.0$ & E 1.1 & $<2.0$ & 2.1 \\
\hline
\end{tabular}


Duplicate samples were used to evaluate the reproducibility (precision) of analytical results. The duplicate samples consisted of stormwater split into two separate samples and sent to the NWQL for analysis. The relative percent difference (RPD) for two values ( $a$ and $b$ ) is calculated according to the following equation:

$$
\mathrm{RPD}=|\{(\mathrm{a}-\mathrm{b}) \div[(\mathrm{a}+\mathrm{b}) \div 2]\} \times 100|
$$

For example, if the environmental sample (a) result is 18 , and the duplicate (b) is 20 , the RPD (absolute value) is 10.52 percent. If censored values were reported for both results in a comparison, they were counted as a "zero" RPD. If one result was censored and the other result was not, the RPD was not computed. For small concentrations, small differences in analytical results near the reporting level can result in large RPDs. Some constituents showed this tendency, but analysis of the distribution of the RPDs and the associated concentration or measured value seemed to indicate mostly random distribution of RPD values. For the 151 duplicate analyses, the median RPD was 1.9 percent, and RPDs ranged from 0 to 115 percent (table 6). For the 151 duplicate analyses, the 90th-percentile RPDs ranged from 0.4 to 45 percent. Among those results dissolved copper, lead, and manganese, accounted for the largest RPDs (90th-percentile RPDs ranged from 34 to 45 percent). Excluding these dissolved metals, the range of 90th-percentile values in table 6 was 0.4 to 20 percent (table 6). The RPD results indicate generally satisfactory reproducibility for the majority water-quality analysis types. For the dissolved metals - copper, lead, and manganese - reproducibility was only fair. 
Table 6. Relative percentage difference statistics for duplicate samples collected during 2006-2010.

$\left[\mathrm{ft}^{3} / \mathrm{s}\right.$, cubic foot per second; $\mu \mathrm{S} / \mathrm{cm}$ at $25^{\circ} \mathrm{C}$, microsiemens per centimeter at 25 degrees Celsius; ${ }^{\circ} \mathrm{C}$, Celsius; $\mathrm{CaCO}_{3}$, calcium carbonate; $\mathrm{mg} / \mathrm{L}$, milligrams per liter; $\mu \mathrm{g} / \mathrm{L}$, micrograms per liter; mm, millimeter; $\mathrm{N}$, nitrogen; $\mathrm{P}$, phosphorus; $\mathrm{C}$, carbon; $\mathrm{n}$, number of samples ]

\begin{tabular}{|c|c|c|c|c|c|c|c|c|}
\hline Property or constituent & $\mathbf{n}$ & Minimum & Maximum & $\begin{array}{c}\text { 10th } \\
\text { percentile }\end{array}$ & $\begin{array}{c}\text { 25th } \\
\text { percentile }\end{array}$ & Median & $\begin{array}{c}\text { 75th } \\
\text { percentile }\end{array}$ & $\begin{array}{c}\text { 90th } \\
\text { percentile }\end{array}$ \\
\hline Specific conductance, field, $\mu \mathrm{S} / \mathrm{cm}$ at $25^{\circ} \mathrm{C}$ & 8 & 0 & 0.5 & 0 & 0 & 0 & 0.2 & 0.4 \\
\hline Hardness, total as $\mathrm{CaCO}_{3}$, in $\mathrm{mg} / \mathrm{L}$ & 8 & 0 & 5.4 & 0 & 0.5 & 0.8 & 3.2 & 4.5 \\
\hline Calcium, dissolved, $\mathrm{mg} / \mathrm{L}$ & 8 & 0.2 & 4.4 & 0.2 & 0.4 & 0.9 & 3.0 & 3.6 \\
\hline Magnesium, dissolved, mg/L & 8 & 0 & 2.7 & 0 & 0.2 & 1.0 & 1.5 & 2.3 \\
\hline Residue on evaporation at $105^{\circ} \mathrm{C}, \mathrm{mg} / \mathrm{L}$ & 8 & 1.3 & 24 & 2.3 & 3.8 & 6.6 & 13 & 18 \\
\hline Nitrogen, ammonia plus organic, total as $\mathrm{N}, \mathrm{mg} / \mathrm{L}$ & 7 & 0 & 10 & 0 & 0.6 & 6.9 & 8.9 & 9.7 \\
\hline Nitrogen, ammonia, dissolved as $\mathrm{N}, \mathrm{mg} / \mathrm{L}$ & 8 & 0 & 22 & 0 & 0.0 & 0.9 & 3.2 & 12 \\
\hline Nitrogen, nitrite plus nitrate, dissolved as $\mathrm{N}, \mathrm{mg} / \mathrm{L}$ & 8 & 0 & 1.9 & 0 & 1.0 & 1.5 & 1.7 & 1.9 \\
\hline Orthophosphate, dissolved as $\mathrm{P}, \mathrm{mg} / \mathrm{L}$ & 8 & 0 & 20 & 0 & 0 & 1.2 & 7.6 & 20 \\
\hline Phosphorus, total as $\mathrm{P}, \mathrm{mg} / \mathrm{L}$ & 8 & 0 & 10 & 0 & 1.4 & 3.5 & 5.8 & 9.4 \\
\hline Carbon, organic, dissolved as $\mathrm{C}, \mathrm{mg} / \mathrm{L}$ & 8 & 0 & 5.7 & 0.9 & 1.3 & 2.4 & 3.8 & 4.6 \\
\hline Copper, dissolved, $\mu \mathrm{g} / \mathrm{L}$ & 8 & 0 & 115 & 2.9 & 6.4 & 12 & 15 & 45 \\
\hline Copper, total recoverable, $\mu \mathrm{g} / \mathrm{L}$ & 8 & 1.0 & 17 & 1.4 & 2.1 & 2.7 & 3.1 & 7.7 \\
\hline Lead, dissolved, $\mu \mathrm{g} / \mathrm{L}$ & 8 & 0 & 55 & 0 & 0 & 26 & 37 & 43 \\
\hline Lead, total recoverable, $\mu \mathrm{g} / \mathrm{L}$ & 8 & 0.2 & 7.3 & 0.2 & 1.9 & 3.1 & 4.2 & 6.9 \\
\hline Manganese, dissolved, $\mu \mathrm{g} / \mathrm{L}$ & 8 & 0 & 108 & 0.1 & 0.6 & 0.9 & 1.7 & 34 \\
\hline Manganese, total recoverable, $\mu \mathrm{g} / \mathrm{L}$ & 8 & 0.2 & 5.1 & 0.3 & 0.3 & 1.3 & 2.3 & 4.7 \\
\hline Zinc, dissolved, $\mu \mathrm{g} / \mathrm{L}$ & 8 & 0.4 & 19 & 0.4 & 5.4 & 8.1 & 9.4 & 13 \\
\hline Zinc, total recoverable, $\mu \mathrm{g} / \mathrm{L}$ & 8 & 0 & 16 & 0.6 & 1.6 & 2.0 & 5.9 & 9.1 \\
\hline
\end{tabular}




\section{Summary of Stormwater Quality}

The results of laboratory analyses of stormwater samples for water-quality properties and constituents and biological indicators are summarized in this section. Summary statistics of laboratory results are presented for each of the five stations. In addition, analytical results are compared to numeric standards established by the CDPHE (Colorado Department of Public Health and Environment, 2011a, 2011b). Hydrographs of daily mean streamflow for each streamflowgaging station and the dates of sampling events are presented in figure 3 . The streamflow plots, in addition to the streamflow characteristics of the stations listed in table 3 , provide a context for the hydrologic setting of stormwater collection. Precipitation data on the hydrographs were collected at the same station (Union, Toll Gate, Sand Creek, and Henderson) or at a nearby location (Denver), and the exact locations of the precipitation gages are listed in table 1.

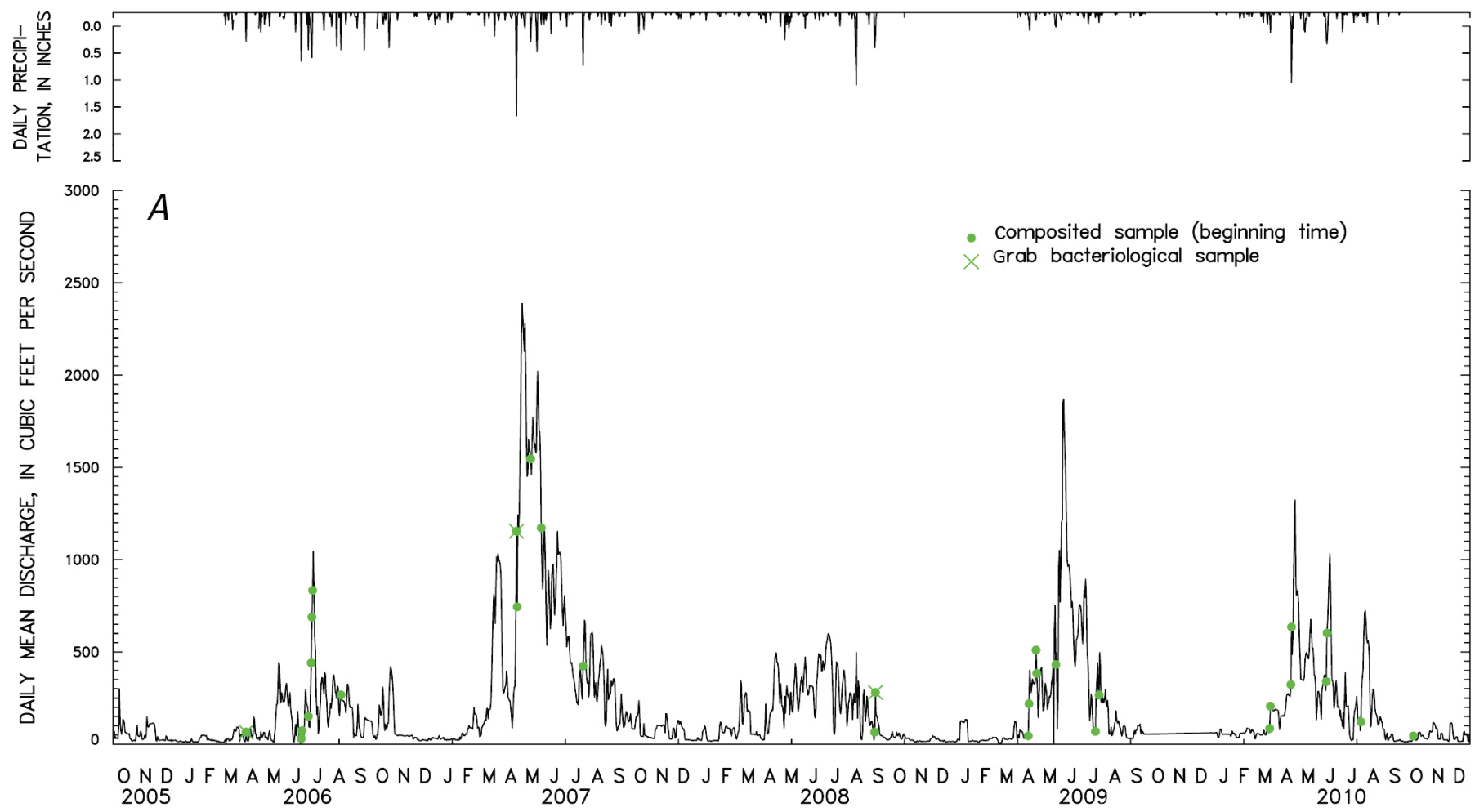

Figure 3. Graphs showing daily values for streamflow and precipitation and dates of sample collection (2006-2010) at (A) South Platte River below Union Avenue at Englewood, (B) South Platte River at Denver, $(C)$ Toll Gate Creek above 6th Avenue at Aurora, $(D)$ Sand Creek at mouth near Commerce City, and $(E)$ South Platte River at Henderson. 

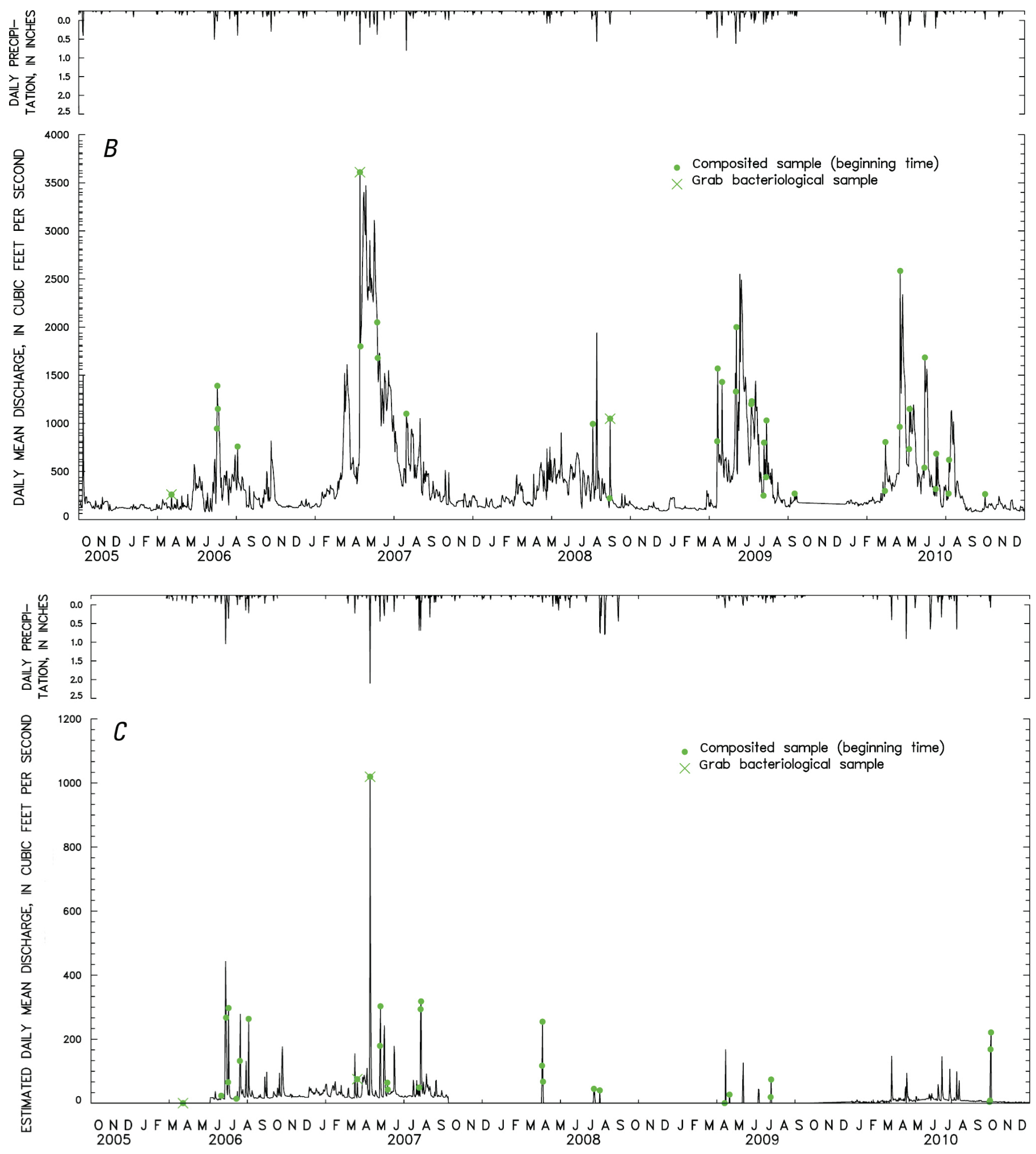

Figure 3. Graphs showing daily values for streamflow and precipitation and dates of sample collection (2006-2010) at (A) South Platte River below Union Avenue at Englewood, (B) South Platte River at Denver, $(C)$ Toll Gate Creek above 6th Avenue at Aurora, $(D)$ Sand Creek at mouth near Commerce City, and $(E)$ South Platte River at Henderson.-Continued 

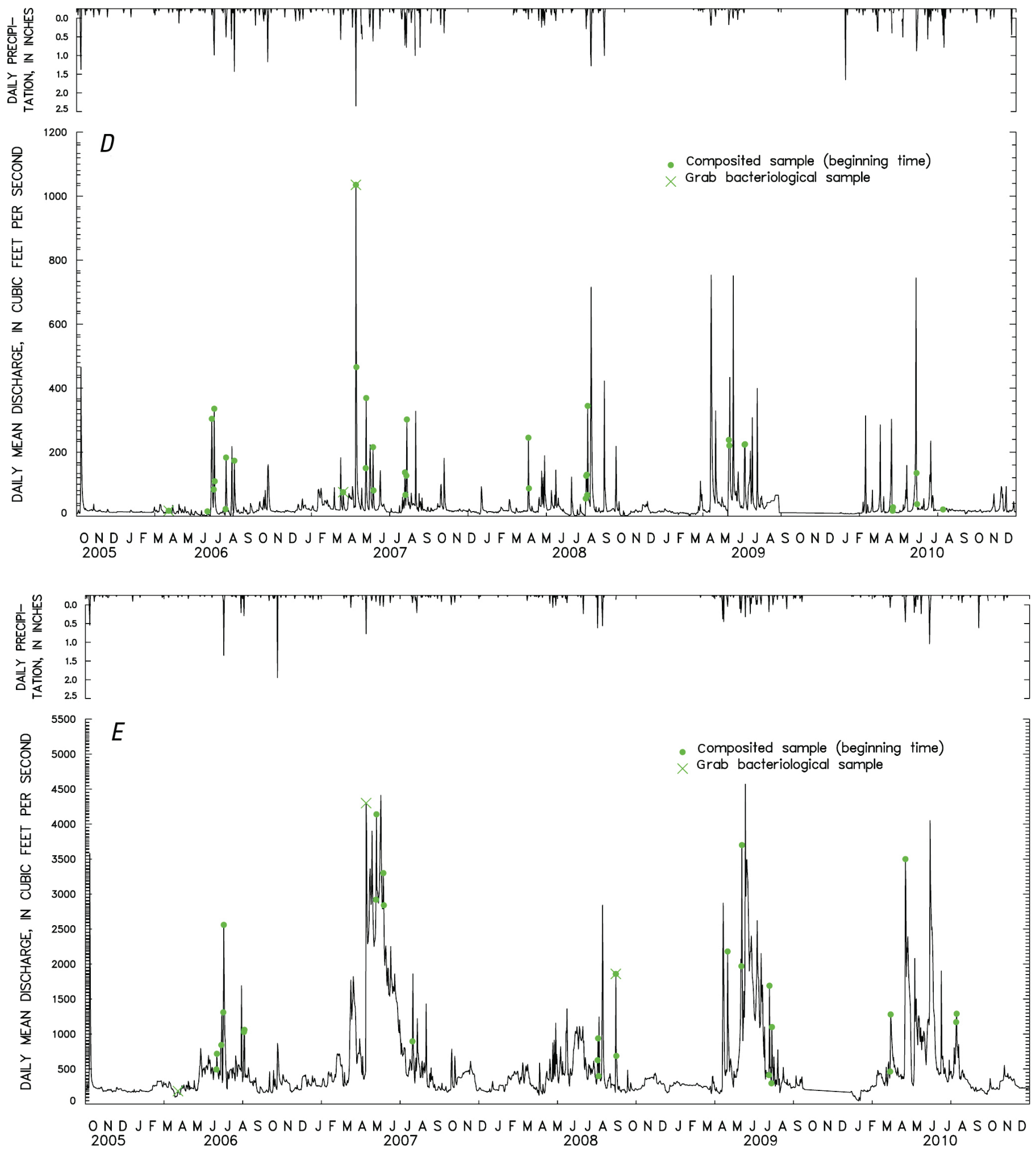

Figure 3. Graphs showing daily values for streamflow and precipitation and dates of sample collection (2006-2010) at (A) South Platte River below Union Avenue at Englewood, (B) South Platte River at Denver, $(C)$ Toll Gate Creek above 6th Avenue at Aurora, $(D)$ Sand Creek at mouth near Commerce City, and $(E)$ South Platte River at Henderson.-Continued 


\section{Water Quality of Stormwater Samples}

A total of 197 composite samples were collected from 2006 through 2010; about 30 to 50 samples were collected at each station. Samples were collected during periods of rising, peak, or falling surface-water levels. Sampling events (2006-2010) are shown on hydrographs for each of the five stations (fig. 3).

Summary statistics of streamflow, water-quality properties and constituents, including bacteriological results, are presented in table 7 and illustrated with boxplots in figure 4 for each of the five stations. Table 7 also reports the number of samples that had censored values-

unquantifiable concentrations that were less than the reporting level. Some reporting levels varied during 2006-2010 (table 7). Water-quality constituents having censored values included residue on evaporation, dissolved ammonia, dissolved orthophosphate, and dissolved copper and lead. 
Table 7. Statistics for concentrations and measurement values at stormwater sampling sites, 2006-2010.

$\left[\mathrm{ft}^{3} / \mathrm{s}\right.$, cubic foot per second; $\mathrm{mL}$, milliliter; $\mu \mathrm{S} / \mathrm{cm}$, microsiemens per centimeter at 25 degrees Celsius; CaCO 3 , calcium carbonate; mg/L, milligrams per liter; $\mu \mathrm{g} / \mathrm{L}$, micrograms per liter; N, nitrogen; $\mathrm{P}$, phosphorus; $\mathrm{C}$, carbon; SD, standard deviation; $\mathrm{n}$, number of samples; nlt, number of "less thans" or censored data; --, not calculated; \%, percentile; MPN, most probable number]

\begin{tabular}{|c|c|c|c|c|c|c|c|c|c|c|}
\hline \multirow{2}{*}{$\begin{array}{l}\text { Property or } \\
\text { constituent }\end{array}$} & \multicolumn{5}{|c|}{ Summary statistics } & \multirow{2}{*}{$\mathrm{n}$} & \multirow{2}{*}{ nlt } & \multicolumn{2}{|c|}{$\begin{array}{c}\text { Range of uncensored } \\
\text { values }\end{array}$} & \multirow{2}{*}{$\begin{array}{l}\text { Censoring } \\
\text { level }\end{array}$} \\
\hline & Mean & SD & $25 \%$ & $\begin{array}{l}\text { Median } \\
50 \% \\
\end{array}$ & $75 \%$ & & & Minimum & Maximum & \\
\hline & \multicolumn{10}{|c|}{06710247 South Platte River below Union Avenue at Englewood, Colorado } \\
\hline Streamflow, mean, $\mathrm{ft}^{3} / \mathrm{s}$ & 410 & 312 & 131 & 346 & 632. & 38 & 0 & 33 & 1,490 & -- \\
\hline Streamflow, volume, acre-feet & 378 & 282 & 136 & 322 & 574 & 38 & 0 & 30 & 1,360 & -- \\
\hline $\mathrm{pH}$, standard units & 7.7 & 0.2 & 7.6 & 7.7 & 7.8 & 38 & 0 & 6.9 & 8.4 & -- \\
\hline Specific conductance, $\mu \mathrm{S} / \mathrm{cm}$ & 490 & 210 & 345 & 409 & 585 & 38 & 0 & 226 & 993 & -- \\
\hline Hardness, total, $\mathrm{mg} / \mathrm{L}$ as $\mathrm{CaCO}_{3}$ & 145 & 47.4 & 113 & 133 & 164 & 38 & 0 & 81.5 & 290 & -- \\
\hline Calcium, mg/L & 43 & 13 & 33 & 39 & 47 & 38 & 0 & 24 & 84 & -- \\
\hline Magnesium, mg/L & 9.3 & 3.6 & 6.8 & 7.9 & 11 & 38 & 0 & 5.1 & 20 & -- \\
\hline $\begin{array}{l}\text { Suspended solids, residue on evaporation } \\
\text { at } 105^{\circ} \mathrm{C}, \mathrm{mg} / \mathrm{L} \\
\text { Nitrogen, total, ammonia plus organic as }\end{array}$ & 226 & 183 & 77 & 196 & 326 & 37 & 1 & 16 & 670 & -- \\
\hline $\mathrm{N}, \mathrm{mg} / \mathrm{L}$ & 1.4 & 0.72 & 0.83 & 1.4 & 1.7 & 8 & 0 & 0.46 & 4.00 & -- \\
\hline $\begin{array}{l}\text { Nitrogen, dissolved, ammonia as } \mathrm{N}, \mathrm{mg} / \mathrm{L} \\
\text { Nitrogen, dissolved, nitrite plus nitrate as }\end{array}$ & 0.06 & 0.06 & 0.02 & 0.05 & 0.08 & 38 & 6 & 0.01 & 6.00 & 0.01 \\
\hline $\mathrm{N}, \mathrm{mg} / \mathrm{L}$ & 0.82 & 0.56 & 0.42 & 0.59 & 1.03 & 38 & 0 & 0.17 & 2.71 & -- \\
\hline Orthophosphate, dissolved as $\mathrm{P}, \mathrm{mg} / \mathrm{L}$ & 0.059 & 0.051 & 0.024 & 0.043 & 0.068 & 38 & 0 & 0.004 & 0.237 & -- \\
\hline Phosphorus, total as $\mathrm{P}, \mathrm{mg} / \mathrm{L}$ & 0.38 & 0.24 & 0.22 & 0.35 & 0.49 & 38 & 0 & 0.07 & 0.98 & -- \\
\hline Carbon, dissolved, organic as $\mathrm{C}, \mathrm{mg} / \mathrm{L}$ & 6.7 & 3.0 & 4.8 & 6.1 & 7.5 & 38 & 0 & 2.9 & 18.6 & -- \\
\hline Escherichia coli, MPN/100 mL & 5,380 & 5,620 & -- & 5,380 & -- & 4 & 0 & 20 & 11,000 & -- \\
\hline Fecal coliform, MPN/100 mL & 6,180 & 6,200 & -- & 6,180 & -- & 4 & 0 & 20 & 12,000 & -- \\
\hline Copper, dissolved, $\mu \mathrm{g} / \mathrm{L}$ & 2.1 & 0.8 & 1.6 & 1.9 & 2.6 & 38 & 0 & 1.1 & 4.6 & -- \\
\hline Copper, total recoverable, $\mu \mathrm{g} / \mathrm{L}$ & 11 & 7.9 & 5.4 & 11 & 14 & 36 & 0 & 2.9 & 34 & -- \\
\hline Lead, dissolved, $\mu \mathrm{g} / \mathrm{L}$ & 0.08 & 0.06 & 0.04 & 0.06 & 0.07 & 38 & 6 & 0.03 & 0.27 & $0.04,0.06$ \\
\hline Lead, total recoverable, $\mu \mathrm{g} / \mathrm{L}$ & 8.3 & 7.2 & 2.6 & 7.4 & 10.3 & 36 & 0 & 0.62 & 26.9 & -- \\
\hline Manganese, dissolved, $\mu \mathrm{g} / \mathrm{L}$ & 19.5 & 26.0 & 6.4 & 11.6 & 20.6 & 38 & 0 & 0.2 & 119 & -- \\
\hline Manganese, total recoverable, $\mu \mathrm{g} / \mathrm{L}$ & 304 & 242 & 143 & 263 & 379 & 36 & 0 & 42.2 & 884 & -- \\
\hline Zinc, dissolved, $\mu \mathrm{g} / \mathrm{L}$ & 5.3 & 3.0 & 2.8 & 4.8 & 6.9 & 38 & 0 & 1.8 & 13.6 & -- \\
\hline Zinc, total recoverable, $\mu \mathrm{g} / \mathrm{L}$ & 40 & 29 & 19 & 34 & 53 & 36 & 0 & 7 & 134 & -- \\
\hline
\end{tabular}


Table 7. Statistics for concentrations and measurement values at stormwater sampling sites, 2006-2010._Continued

$\left[\mathrm{ft}^{3} / \mathrm{s}\right.$, cubic foot per second; $\mathrm{mL}$, milliliter; $\mu \mathrm{S} / \mathrm{cm}$, microsiemens per centimeter at 25 degrees Celsius; $\mathrm{CaCO}, \mathrm{Cal}_{3}, \mathrm{cium}$ carbonate; mg/L, milligrams per liter; $\mu \mathrm{g} / \mathrm{L}$, micrograms per liter; N, nitrogen; P, phosphorus; $\mathrm{C}$, carbon; SD, standard deviation; n, number of samples; nlt, number of "less thans" or censored data; --, not calculated; \%, percentile; MPN, most probable number]

\begin{tabular}{|c|c|c|c|c|c|c|c|c|c|c|}
\hline \multirow{2}{*}{$\begin{array}{l}\text { Property or } \\
\text { constituent }\end{array}$} & \multicolumn{5}{|c|}{ Summary statistics } & \multirow{2}{*}{$\mathbf{n}$} & \multirow{2}{*}{ nlt } & \multicolumn{2}{|c|}{$\begin{array}{l}\text { Range of uncensored } \\
\text { values }\end{array}$} & \multirow{2}{*}{$\begin{array}{c}\text { Censoring } \\
\text { level }\end{array}$} \\
\hline & Mean & SD & $25 \%$ & $\begin{array}{l}\text { Median } \\
50 \%\end{array}$ & $75 \%$ & & & Minimum & Maximum & \\
\hline & \multicolumn{10}{|c|}{06714000 South Platte River at Denver, Colorado } \\
\hline Streamflow, mean, $\mathrm{ft}^{3} / \mathrm{s}$ & 1,480 & 1,370 & 656 & 1,090 & 1,790 & 49 & 0 & 184 & 8,083 & -- \\
\hline Streamflow, volume, acre-feet & 1,410 & 1,280 & 667 & 1,010 & 1,630 & 49 & 0 & 168 & 7,350 & -- \\
\hline $\mathrm{pH}$, standard units & 7.5 & 0.3 & 7.5 & 7.5 & 7.7 & 48 & 0 & 6.6 & 8.0 & -- \\
\hline Specific conductance, $\mu \mathrm{S} / \mathrm{cm}$ & 522 & 225 & 384 & 491 & 597 & 46 & 0 & 260 & 1,390 & -- \\
\hline Hardness, total, $\mathrm{mg} / \mathrm{L}$ as $\mathrm{CaCO}_{3}$ & 141 & 43 & 108 & 138 & 160 & 48 & 0 & 74.4 & 251 & -- \\
\hline Calcium, $\mathrm{mg} / \mathrm{L}$ & 42 & 12 & 32 & 42 & 49 & 48 & 0 & 22 & 76 & -- \\
\hline Magnesium, mg/L & 8.6 & 3.1 & 6.2 & 8 & 9.8 & 48 & 0 & 4.3 & 18 & -- \\
\hline $\begin{array}{l}\text { Suspended solids, residue on evaporation } \\
\text { at } 105^{\circ} \mathrm{C}, \mathrm{mg} / \mathrm{L}\end{array}$ & 202 & 125 & 122 & 180 & 258 & 47 & 0 & 20.0 & 660 & -- \\
\hline Nitrogen, total, ammonia plus organic as & & & & & & & & & & \\
\hline $\mathrm{N}, \mathrm{mg} / \mathrm{L}$ & 1.8 & 0.82 & 1.2 & 1.5 & 2.2 & 7 & 0 & 0.51 & 4.2 & - \\
\hline Nitrogen, dissolved, ammonia as $\mathrm{N}, \mathrm{mg} / \mathrm{L}$ & 0.12 & 0.13 & 0.03 & 0.07 & 0.13 & 47 & 4 & 0.01 & 0.60 & 0.01 \\
\hline Nitrogen, dissolved, nitrite plus nitrate as & & & & & & & & & & -- \\
\hline $\mathrm{N}, \mathrm{mg} / \mathrm{L}$ & 1.21 & 0.65 & 0.80 & 0.98 & 1.38 & 46 & 0 & 0.55 & 3.69 & \\
\hline Orthophosphate, dissolved as $\mathrm{P}, \mathrm{mg} / \mathrm{L}$ & 0.150 & 0.087 & 0.098 & 0.122 & 0.167 & 47 & 0 & 0.046 & 0.487 & -- \\
\hline Phosphorus, total as $\mathrm{P}, \mathrm{mg} / \mathrm{L}$ & 0.54 & 0.24 & 0.39 & 0.47 & 0.65 & 47 & 0 & 0.14 & 1.33 & -- \\
\hline Carbon, dissolved, organic as $\mathrm{C}, \mathrm{mg} / \mathrm{L}$ & 6.3 & 2.0 & 5.0 & 5.8 & 7.2 & 48 & 0 & 4.1 & 12.2 & -- \\
\hline Escherichia coli, MPN/100 mL & 8,900 & 9,926 & -- & 6,250 & -- & 4 & 0 & 110 & 23,000 & -- \\
\hline Fecal coliform, MPN/100 mL & 10,520 & 9,486 & -- & 9,450 & -- & 4 & 0 & 170 & 23,000 & -- \\
\hline Copper, dissolved, $\mu \mathrm{g} / \mathrm{L}$ & 2.9 & 1.2 & 2.2 & 2.5 & 3.3 & 48 & 1 & 1.5 & 7.0 & 1 \\
\hline Copper, total recoverable, $\mu \mathrm{g} / \mathrm{L}$ & 17 & 11 & 9.1 & 15 & 21 & 45 & 0 & 3.8 & 67 & -- \\
\hline Lead, dissolved, $\mu \mathrm{g} / \mathrm{L}$ & 0.118 & 0.062 & 0.075 & 0.1 & 0.155 & 48 & 0 & 0.04 & 0.31 & -- \\
\hline Lead, total recoverable, $\mu \mathrm{g} / \mathrm{L}$ & 15.2 & 13.7 & 6.72 & 13.1 & 18 & 45 & 0 & 2.13 & 79.5 & -- \\
\hline Manganese, dissolved, $\mu \mathrm{g} / \mathrm{L}$ & 11 & 25 & 1.1 & 3.3 & 9.7 & 48 & 0 & 0.1 & 156 & -- \\
\hline Manganese, total recoverable, $\mu \mathrm{g} / \mathrm{L}$ & 333 & 182 & 215 & 288 & 412 & 45 & 0 & 77.9 & 873 & -- \\
\hline Zinc, dissolved, $\mu \mathrm{g} / \mathrm{L}$ & 8.3 & 4.5 & 5.0 & 6.8 & 10.6 & 48 & 0 & 3.3 & 21.3 & -- \\
\hline Zinc, total recoverable, $\mu \mathrm{g} / \mathrm{L}$ & 71 & 51 & 33 & 60 & 91 & 45 & 0 & 13 & 287 & -- \\
\hline
\end{tabular}


Table 7. Statistics for concentrations and measurement values at stormwater sampling sites, 2006-2010._Continued

$\left[\mathrm{ft}^{3} / \mathrm{s}\right.$, cubic foot per second; $\mathrm{mL}$, milliliter; $\mu \mathrm{S} / \mathrm{cm}$, microsiemens per centimeter at 25 degrees Celsius; CaCO 3 , calcium carbonate; mg/L, milligrams per liter; $\mu \mathrm{g} / \mathrm{L}$, micrograms per liter; $\mathrm{N}$, nitrogen; $\mathrm{P}$, phosphorus; $\mathrm{C}$, carbon; $\mathrm{SD}$, standard deviation; $\mathrm{n}$, number of samples; nlt, number of "less thans" or censored data; --, not calculated; \%, percentile; MPN, most probable number]

\begin{tabular}{|c|c|c|c|c|c|c|c|c|c|c|}
\hline \multirow{2}{*}{$\begin{array}{l}\text { Property or } \\
\text { constituent }\end{array}$} & \multicolumn{5}{|c|}{ Summary statistics } & \multirow{2}{*}{$\mathbf{n}$} & \multicolumn{3}{|c|}{$\begin{array}{l}\text { Range of uncensored } \\
\text { values }\end{array}$} & \multirow{2}{*}{$\begin{array}{l}\text { Censoring } \\
\text { level }\end{array}$} \\
\hline & Mean & SD & $25 \%$ & $\begin{array}{l}\text { Median } \\
50 \%\end{array}$ & $75 \%$ & & & Minimum & Maximum & \\
\hline & \multicolumn{10}{|c|}{394329104490101 Toll Gate Creek above 6th Avenue near Aurora, Colorado } \\
\hline Streamflow, mean, $\mathrm{ft}^{3} / \mathrm{s}$ & 261 & 289 & 73 & 182 & 345 & 30 & 0 & 4 & 1,400 & -- \\
\hline Streamflow, volume, acre-feet & 242 & 241 & 67 & 156 & 313 & 30 & 0 & 4 & 921 & -- \\
\hline $\mathrm{pH}$, standard units & 7.7 & 0.2 & 7.5 & 7.6 & 7.8 & 33 & 0 & 7.4 & 8.0 & -- \\
\hline Specific conductance, $\mu \mathrm{S} / \mathrm{cm}$ & 1,112 & 506 & 720 & 957 & 1,500 & 31 & 0 & 363 & 2,230 & -- \\
\hline Hardness, total, $\mathrm{mg} / \mathrm{L}$ as $\mathrm{CaCO}_{3}$ & 316 & 167 & 193 & 251 & 418 & 33 & 0 & 84.6 & 746 & -- \\
\hline Calcium, mg/L & 95 & 50 & 60 & 77 & 129 & 33 & 0 & 26 & 226 & -- \\
\hline Magnesium, mg/L & 19 & 10 & 11 & 15 & 24 & 33 & 0 & 4.6 & 44 & -- \\
\hline $\begin{array}{l}\text { Suspended solids, residue on evaporation } \\
\text { at } 105^{\circ} \mathrm{C}, \mathrm{mg} / \mathrm{L} \\
\text { Nitrogen, total, ammonia plus organic as }\end{array}$ & 180 & 186 & 46 & 97 & 254 & 31 & 0 & 10 & 695 & -- \\
\hline $\mathrm{N}, \mathrm{mg} / \mathrm{L}$ & 1.6 & 0.78 & 1.1 & 1.4 & 2.0 & 32 & 0 & 0.63 & 3.5 & -- \\
\hline $\begin{array}{l}\text { Nitrogen, dissolved, ammonia as } \mathrm{N}, \mathrm{mg} / \mathrm{L} \\
\text { Nitrogen, dissolved, nitrite plus nitrate as }\end{array}$ & 0.14 & 0.15 & 0.04 & 0.09 & 0.20 & 32 & 3 & 0.01 & 0.66 & 0.01 \\
\hline $\mathrm{N}, \mathrm{mg} / \mathrm{L}$ & 0.64 & 0.21 & 0.49 & 0.59 & 0.77 & 32 & 0 & 0.36 & 1.28 & -- \\
\hline Orthophosphate, dissolved as $\mathrm{P}, \mathrm{mg} / \mathrm{L}$ & 0.022 & 0.020 & 0.007 & 0.013 & 0.035 & 32 & 1 & 0.003 & 0.077 & 0.003 \\
\hline Phosphorus, total as $\mathrm{P}, \mathrm{mg} / \mathrm{L}$ & 0.33 & 0.32 & 0.12 & 0.22 & 0.44 & 32 & 0 & 0.04 & 1.38 & -- \\
\hline Carbon, dissolved, organic as $\mathrm{C}, \mathrm{mg} / \mathrm{L}$ & 10.4 & 3.7 & 8.5 & 10.4 & 11.7 & 33 & 0 & 5.3 & 20.9 & -- \\
\hline Escherichia coli, MPN/100 mL & 2,310 & 1,715 & -- & 3,300 & -- & 3 & 0 & 330 & 3,300 & -- \\
\hline Fecal coliform, MPN/100 mL & 2,310 & 1,715 & -- & 3,300 & -- & 3 & 0 & 330 & 3,300 & -- \\
\hline Copper, dissolved, $\mu \mathrm{g} / \mathrm{L}$ & 2.5 & 1.1 & 1.8 & 2.2 & 2.8 & 33 & 0 & 1.0 & 4.9 & -- \\
\hline Copper, total recoverable, $\mu \mathrm{g} / \mathrm{L}$ & 12 & 8.8 & 5.8 & 8.3 & 15 & 33 & 0 & 2.9 & 33 & -- \\
\hline Lead, dissolved, $\mu \mathrm{g} / \mathrm{L}$ & 0.097 & 0.07 & 0.053 & 0.08 & 0.12 & 33 & 4 & 0.04 & 0.34 & $0.04,0.06$ \\
\hline Lead, total recoverable, $\mu \mathrm{g} / \mathrm{L}$ & 7.18 & 7.67 & 2.35 & 3.45 & 9.18 & 33 & 0 & 0.71 & 28.3 & -- \\
\hline Manganese, dissolved, $\mu \mathrm{g} / \mathrm{L}$ & 75.29 & 78.83 & 20.3 & 50.9 & 105 & 33 & 0 & 2.8 & 330 & -- \\
\hline Manganese, total recoverable, $\mu \mathrm{g} / \mathrm{L}$ & 381 & 269 & 192 & 244 & 480 & 33 & 0 & 103 & 1,120 & -- \\
\hline Zinc, dissolved, $\mu \mathrm{g} / \mathrm{L}$ & 8.8 & 5.4 & 4.7 & 8.0 & 11 & 33 & 0 & 1.5 & 26.1 & -- \\
\hline Zinc, total recoverable, $\mu \mathrm{g} / \mathrm{L}$ & 47 & 35 & 24 & 33 & 59 & 33 & 0 & 9 & 132 & -- \\
\hline
\end{tabular}


Table 7. Statistics for concentrations and measurement values at stormwater sampling sites, 2006-2010._Continued

$\left[\mathrm{ft}^{3} / \mathrm{s}\right.$, cubic foot per second; $\mathrm{mL}$, milliliter; $\mu \mathrm{S} / \mathrm{cm}$, microsiemens per centimeter at 25 degrees Celsius; $\mathrm{CaCO}, \mathrm{Cal}_{3}, \mathrm{cium}$ carbonate; mg/L, milligrams per liter; $\mu \mathrm{g} / \mathrm{L}$, micrograms per liter; N, nitrogen; P, phosphorus; $\mathrm{C}$, carbon; SD, standard deviation; n, number of samples; nlt, number of "less thans" or censored data; --, not calculated; \%, percentile; MPN, most probable number]

\begin{tabular}{|c|c|c|c|c|c|c|c|c|c|c|}
\hline \multirow{2}{*}{$\begin{array}{l}\text { Property or } \\
\text { constituent }\end{array}$} & \multicolumn{5}{|c|}{ Summary statistics } & \multirow{2}{*}{$\mathbf{n}$} & \multirow{2}{*}{ nlt } & \multicolumn{2}{|c|}{$\begin{array}{l}\text { Range of uncensored } \\
\text { values }\end{array}$} & \multirow{2}{*}{$\begin{array}{l}\text { Censoring } \\
\text { level }\end{array}$} \\
\hline & Mean & SD & $25 \%$ & $\begin{array}{l}\text { Median } \\
50 \%\end{array}$ & $75 \%$ & & & Minimum & Maximum & \\
\hline & \multicolumn{10}{|c|}{394839104570300 Sand Creek at mouth near Commerce City, Colorado } \\
\hline Streamflow, mean, $\mathrm{ft}^{3} / \mathrm{s}$ & 285 & 275 & 100 & 229 & 374 & 47 & 0 & 21 & 1,620 & -- \\
\hline Streamflow, volume, acre-feet & 255 & 249 & 95 & 205 & 348 & 47 & 0 & 19 & 1,473 & -- \\
\hline $\mathrm{pH}$, standard units & 7.6 & 0.2 & 7.4 & 7.6 & 7.8 & 47 & 0 & 7.3 & 8.0 & -- \\
\hline Specific conductance, $\mu \mathrm{S} / \mathrm{cm}$ & 811 & 392 & 575 & 684 & 908 & 45 & 0 & 330 & 2,020 & -- \\
\hline Hardness, total, $\mathrm{mg} / \mathrm{L}$ as $\mathrm{CaCO}_{3}$ & 195 & 79 & 153 & 171 & 210 & 47 & 0 & 74.8 & 455 & -- \\
\hline Calcium, mg/L & 59 & 22 & 47 & 52 & 64 & 47 & 0 & 23 & 131 & -- \\
\hline Magnesium, mg/L & 12 & 5.6 & 8.4 & 10 & 13 & 47 & 0 & 4.1 & 31 & -- \\
\hline $\begin{array}{l}\text { Suspended solids, residue on evaporation } \\
\text { at } 105^{\circ} \mathrm{C}, \mathrm{mg} / \mathrm{L} \\
\text { Nitrogen, total, ammonia plus organic as }\end{array}$ & 351 & 306 & 128 & 236 & 470 & 47 & 0 & 56.0 & 1,360 & -- \\
\hline $\mathrm{N}, \mathrm{mg} / \mathrm{L}$ & 2.6 & 1.6 & 1.6 & 2.0 & 3.2 & 45 & 0 & 1.1 & 9.5 & -- \\
\hline Nitrogen, dissolved, ammonia as $\mathrm{N}, \mathrm{mg} / \mathrm{L}$ & 0.11 & 0.11 & 0.02 & 0.09 & 0.18 & 45 & 8 & 0.01 & 0.47 & $\begin{array}{c}0.005,0.01 \\
0.02\end{array}$ \\
\hline $\begin{array}{l}\text { Nitrogen, dissolved, nitrite plus nitrate as } \\
\mathrm{N}, \mathrm{mg} / \mathrm{L}\end{array}$ & 0.88 & 0.43 & 0.59 & 0.78 & 0.95 & 45 & 0 & 0.41 & 2.55 & -- \\
\hline Orthophosphate, dissolved as $\mathrm{P}, \mathrm{mg} / \mathrm{L}$ & 0.121 & 0.113 & 0.059 & 0.089 & 0.141 & 45 & 0 & 0.017 & 0.627 & -- \\
\hline Phosphorus, total as $\mathrm{P}, \mathrm{mg} / \mathrm{L}$ & 0.79 & 0.47 & 0.49 & 0.63 & 0.90 & 45 & 0 & 0.27 & 2.36 & -- \\
\hline Carbon, dissolved, organic as $\mathrm{C}, \mathrm{mg} / \mathrm{L}$ & 10.8 & 4.2 & 7.8 & 9.3 & 13.2 & 46 & 0 & 5.8 & 23.6 & -- \\
\hline Escherichia coli, MPN/100 mL & 3,530 & 2,370 & -- & 2,950 & -- & 3 & 0 & 790 & 4,900 & -- \\
\hline Fecal coliform, MPN/100 mL & 2,630 & 2,090 & -- & 2,140 & -- & 3 & 0 & 790 & 4,900 & -- \\
\hline Copper, dissolved, $\mu \mathrm{g} / \mathrm{L}$ & 3.0 & 2.0 & 1.6 & 2.4 & 3.6 & 47 & 0 & 1.2 & 12.5 & -- \\
\hline Copper, total recoverable, $\mu \mathrm{g} / \mathrm{L}$ & 22 & 14 & 11 & 17 & 28 & 47 & 0 & 6.5 & 55 & -- \\
\hline Lead, dissolved, $\mu \mathrm{g} / \mathrm{L}$ & 0.19 & 0.14 & 0.10 & 0.14 & 0.25 & 47 & 0 & 0.04 & 0.74 & -- \\
\hline Lead, total recoverable, $\mu \mathrm{g} / \mathrm{L}$ & 21.0 & 17.3 & 6.16 & 14.5 & 31.6 & 47 & 0 & 3.67 & 60.5 & -- \\
\hline Manganese, dissolved, $\mu \mathrm{g} / \mathrm{L}$ & 45 & 78 & 2.5 & 11 & 59 & 47 & 0 & 0.5 & 391 & -- \\
\hline Manganese, total recoverable, $\mu \mathrm{g} / \mathrm{L}$ & 678 & 661 & 283 & 466 & 640 & 47 & 0 & 144 & 3,210 & -- \\
\hline Zinc, dissolved, $\mu \mathrm{g} / \mathrm{L}$ & 67.2 & 191 & 7.8 & 10.9 & 21.0 & 47 & 0 & 2.8 & 1,170 & -- \\
\hline Zinc, total recoverable, $\mu \mathrm{g} / \mathrm{L}$ & 524 & 1205.4 & 44 & 75 & 241 & 47. & 0 & 22 & 5,230 & -- \\
\hline
\end{tabular}


Table 7. Statistics for concentrations and measurement values at stormwater sampling sites, 2006-2010._Continued

$\left[\mathrm{ft}^{3} / \mathrm{s}\right.$, cubic foot per second; $\mathrm{mL}$, milliliter; $\mu \mathrm{S} / \mathrm{cm}$, microsiemens per centimeter at 25 degrees Celsius; CaCO 3 , calcium carbonate; mg/L, milligrams per liter; $\mu \mathrm{g} / \mathrm{L}$, micrograms per liter; N, nitrogen; P, phosphorus; C, carbon; SD, standard deviation; n, number of samples; nlt, number of "less thans" or censored data; --, not calculated; \%, percentile; MPN, most probable number]

\begin{tabular}{|c|c|c|c|c|c|c|c|c|c|c|}
\hline \multirow{2}{*}{$\begin{array}{l}\text { Property or } \\
\text { constituent }\end{array}$} & \multicolumn{5}{|c|}{ Summary statistics } & \multirow{2}{*}{$\mathbf{n}$} & \multicolumn{3}{|c|}{$\begin{array}{l}\text { Range of uncensored } \\
\text { values }\end{array}$} & \multirow{2}{*}{$\begin{array}{l}\text { Censoring } \\
\text { level }\end{array}$} \\
\hline & Mean & SD & $25 \%$ & $\begin{array}{l}\text { Median } \\
50 \%\end{array}$ & $75 \%$ & & & Minimum & Maximum & \\
\hline & \multicolumn{10}{|c|}{06720500 South Platte River at Henderson, Colorado } \\
\hline Streamflow, mean, $\mathrm{ft}^{3} / \mathrm{s}$ & 2,260 & 3,290 & 754 & 1,470 & 2,390 & 33 & 0 & 218 & 19,000 & -- \\
\hline Streamflow, volume, acre-feet & 1,720 & 1,570 & 663 & 1,340 & 2,040 & 33 & 0 & 198 & 6,920 & -- \\
\hline $\mathrm{pH}$, standard units & 7.3 & 0.2 & 7.2 & 7.4 & 7.5 & 34 & 0 & 6.6 & 7.7 & -- \\
\hline Specific conductance, $\mu \mathrm{S} / \mathrm{cm}$ & 557 & 196 & 454 & 528 & 601 & 34 & 0 & 205 & 1,260 & -- \\
\hline Hardness, total, $\mathrm{mg} / \mathrm{L}$ as $\mathrm{CaCO}_{3}$ & 141 & 31 & 119 & 133 & 154 & 34 & 0 & 95 & 226 & -- \\
\hline Calcium, mg/L & 42 & 9 & 36 & 41 & 47 & 34 & 0 & 28 & 64 & -- \\
\hline Magnesium, mg/L & 8.9 & 2.5 & 7.3 & 8.3 & 10 & 34 & 0 & 6.0 & 17 & -- \\
\hline $\begin{array}{l}\text { Suspended solids, residue on evaporation } \\
\text { at } 105^{\circ} \mathrm{C}, \mathrm{mg} / \mathrm{L} \\
\text { Nitrogen, total, ammonia plus organic as }\end{array}$ & 174 & 112 & 94 & 133 & 242 & 32 & 0 & 44 & 545 & -- \\
\hline $\mathrm{N}, \mathrm{mg} / \mathrm{L}$ & 2.9 & 1.7 & 2.0 & 2.6 & 3.4 & 3 & 0 & 0.96 & 9.4 & -- \\
\hline $\begin{array}{l}\text { Nitrogen, dissolved, ammonia as } \mathrm{N}, \mathrm{mg} / \mathrm{L} \\
\text { Nitrogen, dissolved, nitrite plus nitrate as }\end{array}$ & 0.80 & 0.88 & 0.24 & 0.58 & 0.73 & 33 & 1 & 0.11 & 3.38 & 0.01 \\
\hline $\mathrm{N}, \mathrm{mg} / \mathrm{L}$ & 2.08 & 0.81 & 1.53 & 1.87 & 2.24 & 33 & 0 & 0.96 & 4.64 & -- \\
\hline Orthophosphate, dissolved as $\mathrm{P}, \mathrm{mg} / \mathrm{L}$ & 0.461 & 0.279 & 0.262 & 0.367 & 0.621 & 33 & 0 & 0.152 & 1.15 & -- \\
\hline Phosphorus, total as $\mathrm{P}, \mathrm{mg} / \mathrm{L}$ & 1.02 & 0.46 & 0.72 & 0.96 & 1.18 & 33 & 0 & 0.37 & 2.85 & -- \\
\hline Carbon, dissolved, organic as $\mathrm{C}, \mathrm{mg} / \mathrm{L}$ & 9.1 & 5.3 & 6.2 & 7.5 & 10.6 & 34 & 0 & 4.8 & 34.4 & -- \\
\hline Escherichia coli, MPN/100 mL & 10,400 & 11,550 & -- & 7,900 & -- & 3 & 0 & 310 & 23,000 & -- \\
\hline Fecal coliform, MPN/100 mL & 12,100 & 11,370 & -- & 13,000 & -- & 3 & 0 & 310 & 23,000 & -- \\
\hline Copper, dissolved, $\mu \mathrm{g} / \mathrm{L}$ & 3.04 & 0.92 & 2.4 & 2.75 & 3.4 & 34 & 0 & 1.7 & 5.5 & -- \\
\hline Copper, total recoverable, $\mu \mathrm{g} / \mathrm{L}$ & 24 & 13 & 13 & 22 & 28 & 32 & 0 & 9.1 & 63 & -- \\
\hline Lead, dissolved, $\mu \mathrm{g} / \mathrm{L}$ & 0.22 & 0.08 & 0.17 & 0.21 & 0.29 & 34 & 0 & 0.07 & 0.41 & -- \\
\hline Lead, total recoverable, $\mu \mathrm{g} / \mathrm{L}$ & 22.6 & 15.9 & 10.2 & 17.3 & 32.4 & 32 & 0 & 5.09 & 70.9 & -- \\
\hline Manganese, dissolved, $\mu \mathrm{g} / \mathrm{L}$ & 62 & 127 & 18 & 33 & 62 & 34 & 0 & 0.6 & 757 & -- \\
\hline Manganese, total recoverable, $\mu \mathrm{g} / \mathrm{L}$ & 408 & 305 & 243 & 359 & 472 & 32 & 0 & 138 & 1,840 & -- \\
\hline Zinc, dissolved, $\mu \mathrm{g} / \mathrm{L}$ & 18.3 & 7.5 & 13.1 & 17.3 & 22.1 & 34 & 0 & 6.7 & 45.8 & -- \\
\hline Zinc, total recoverable, $\mu \mathrm{g} / \mathrm{L}$ & 114 & 68 & 68 & 91 & 148 & 32 & 0 & 32 & 308 & -- \\
\hline
\end{tabular}




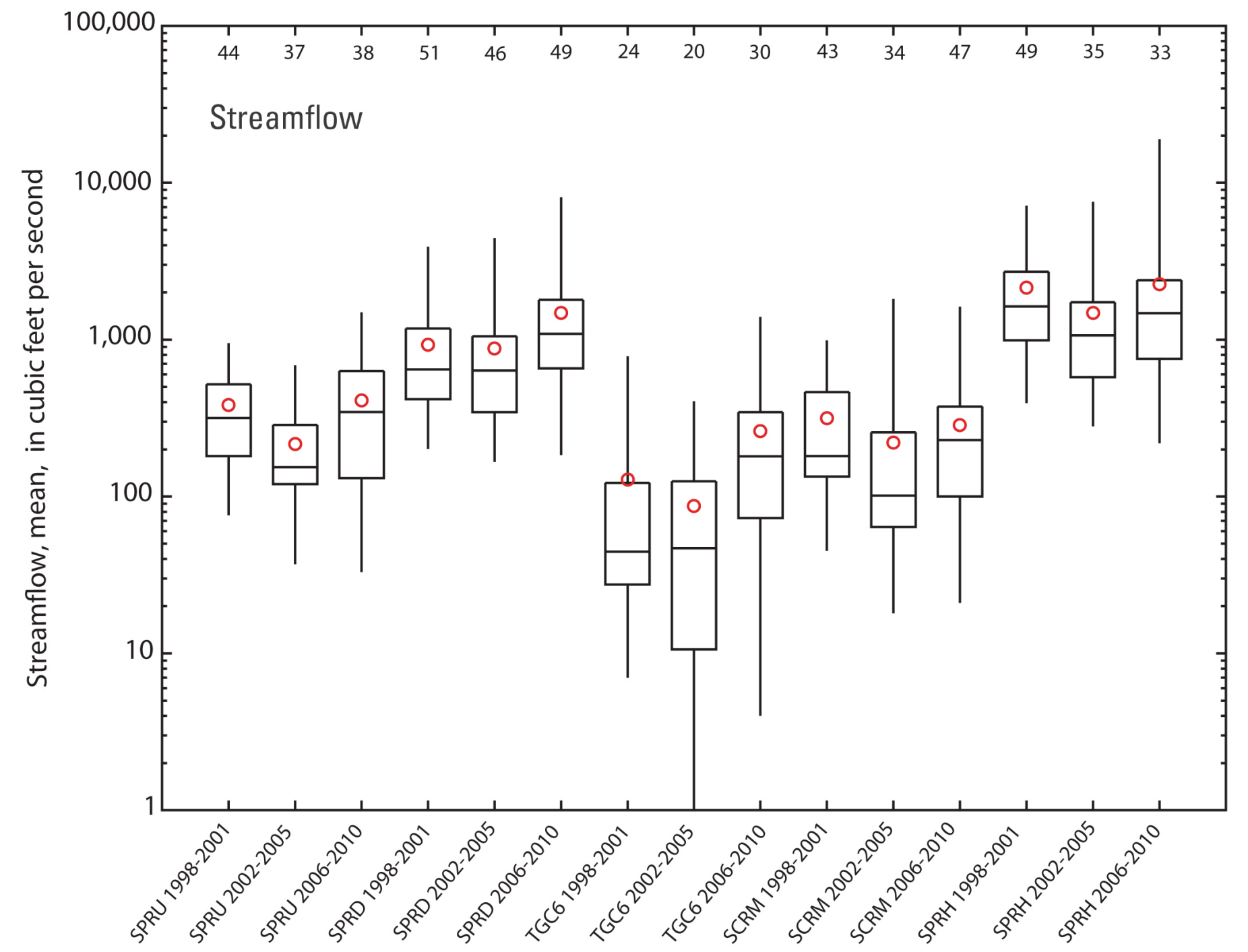

Figure 4. Boxplots showing distribution of water-quality properties and constituents at South Platte River below Union Avenue at Englewood (SPRU), South Platte River at Denver (SPRD), Toll Gate Creek above 6th Avenue at Aurora (TGC6), Sand Creek at mouth near Commerce City (SCRM), and South Platte River at Henderson (SPRH), calendar years 1998-2001, 2002-2005, and 2006-2010. Plotted values and concentrations. Boxplot explanation provided in figure 2 . 


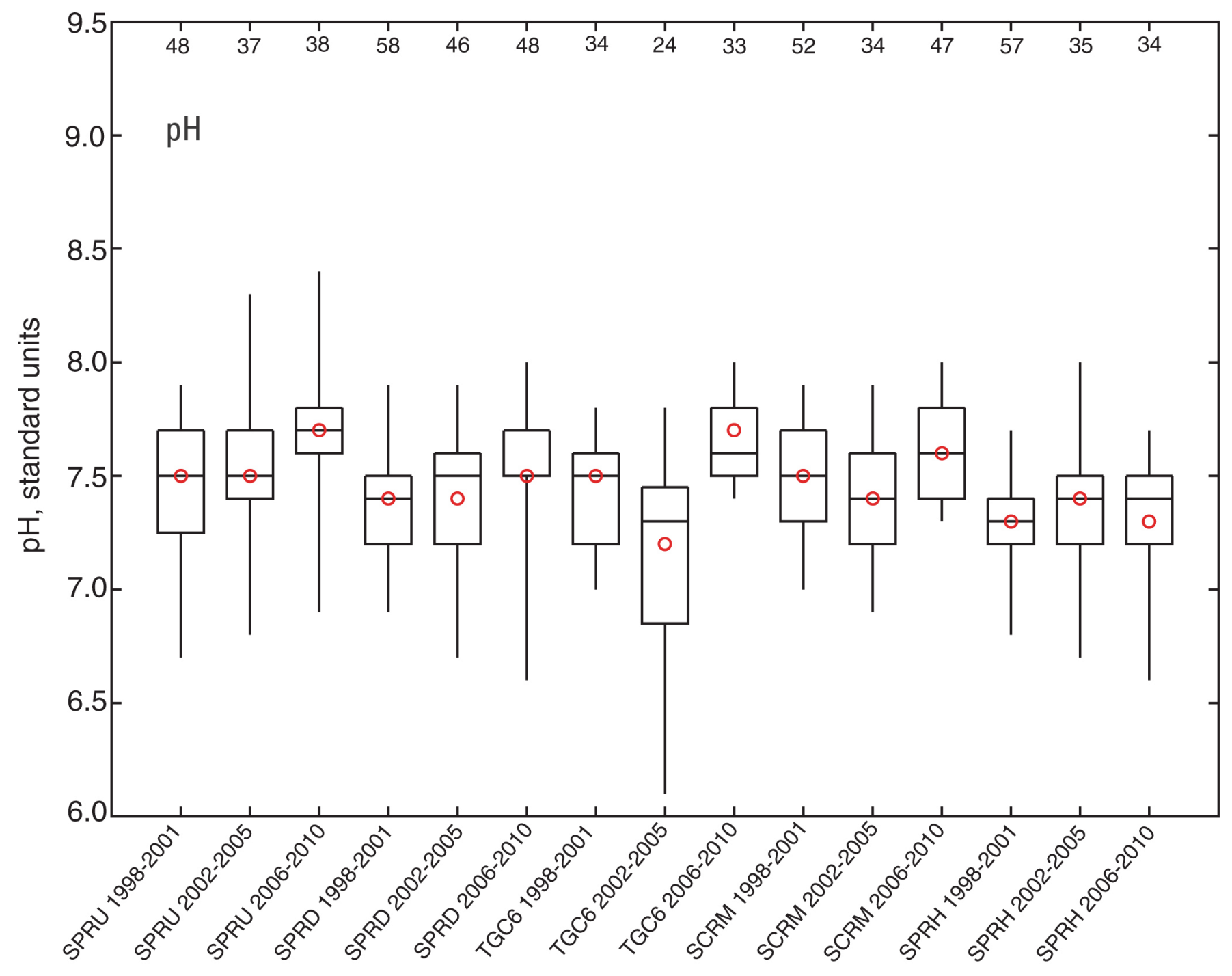

Figure 4. Boxplots showing distribution of water-quality properties and constituents at South Platte River below Union Avenue at Englewood (SPRU), South Platte River at Denver (SPRD), Toll Gate Creek above 6th Avenue at Aurora (TGC6), Sand Creek at mouth near Commerce City (SCRM), and South Platte River at Henderson (SPRH), calendar years 1998-2001, 2002-2005, and 2006-2010. Plotted values and concentrations. Boxplot explanation provided in figure 2.-Continued 


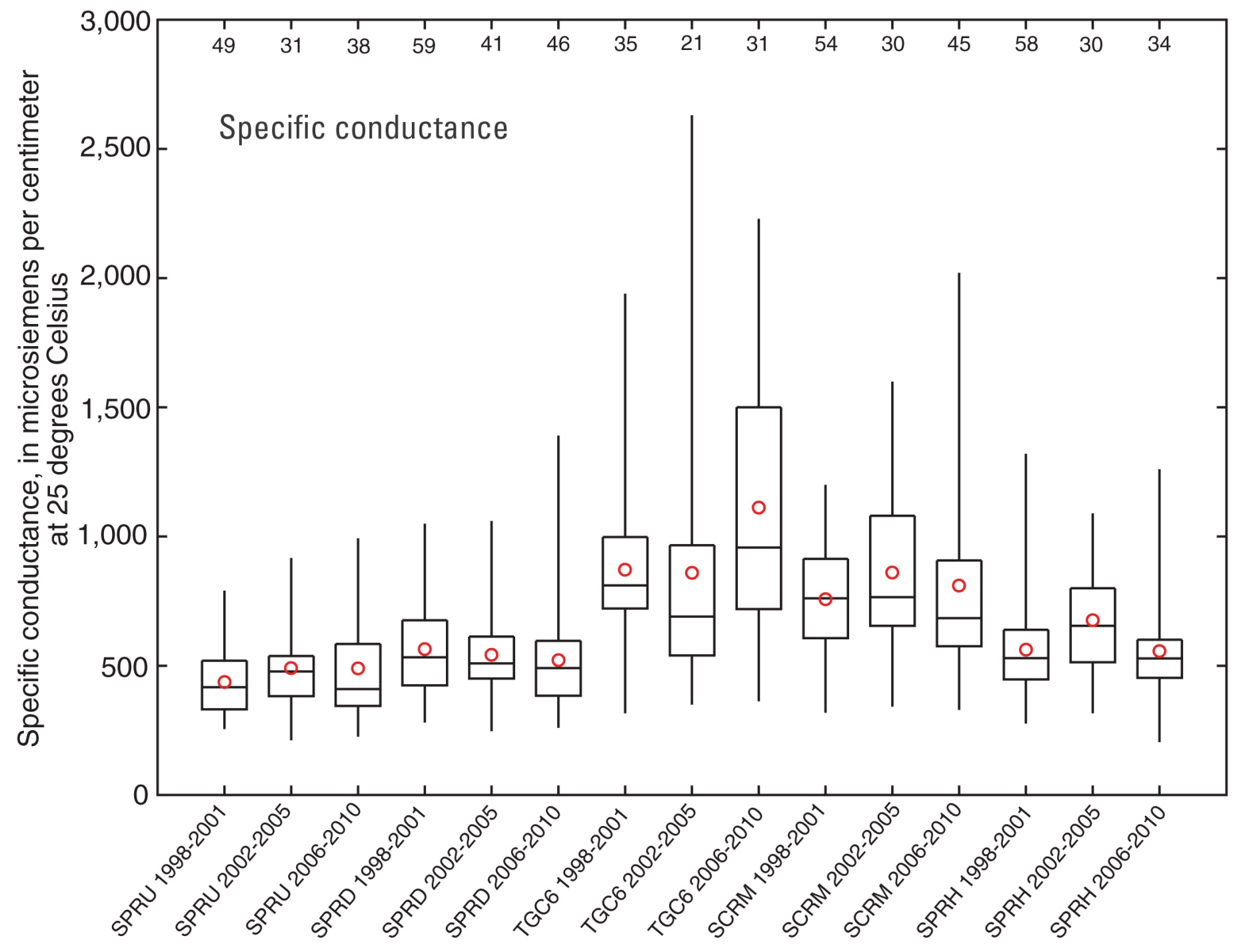

Figure 4. Boxplots showing distribution of water-quality properties and constituents at South Platte River below Union Avenue at Englewood (SPRU), South Platte River at Denver (SPRD), Toll Gate Creek above 6th Avenue at Aurora (TGC6), Sand Creek at mouth near Commerce City (SCRM), and South Platte River at Henderson (SPRH), calendar years 1998-2001, 2002-2005, and 2006-2010. Plotted values and concentrations. Boxplot explanation provided in figure 2.-Continued 


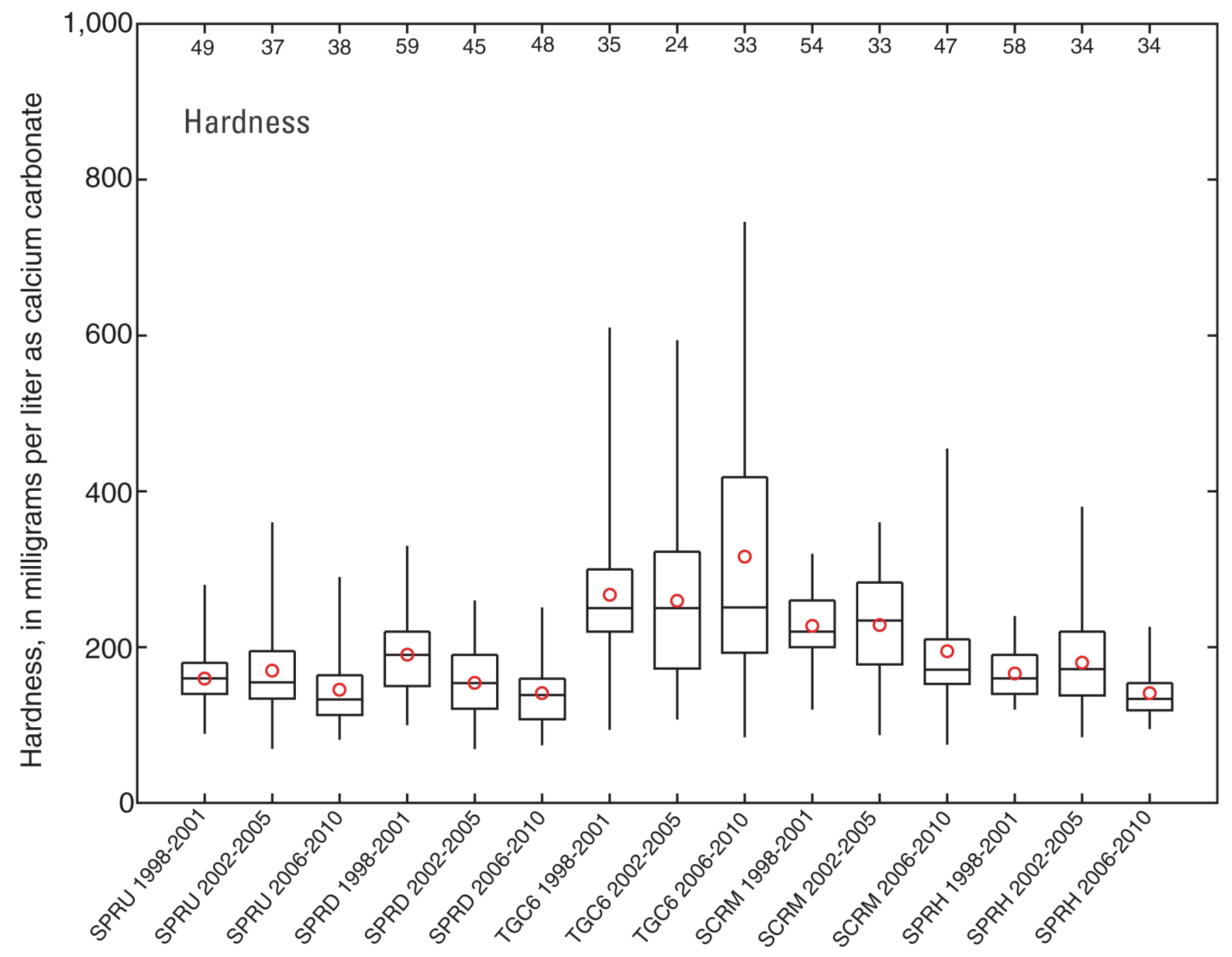

Figure 4. Boxplots showing distribution of water-quality properties and constituents at South Platte River below Union Avenue at Englewood (SPRU), South Platte River at Denver (SPRD), Toll Gate Creek above 6th Avenue at Aurora (TGC6), Sand Creek at mouth near Commerce City (SCRM), and South Platte River at Henderson (SPRH), calendar years 1998-2001, 2002-2005, and 2006-2010. Plotted values and concentrations. Boxplot explanation provided in figure 2.-Continued 


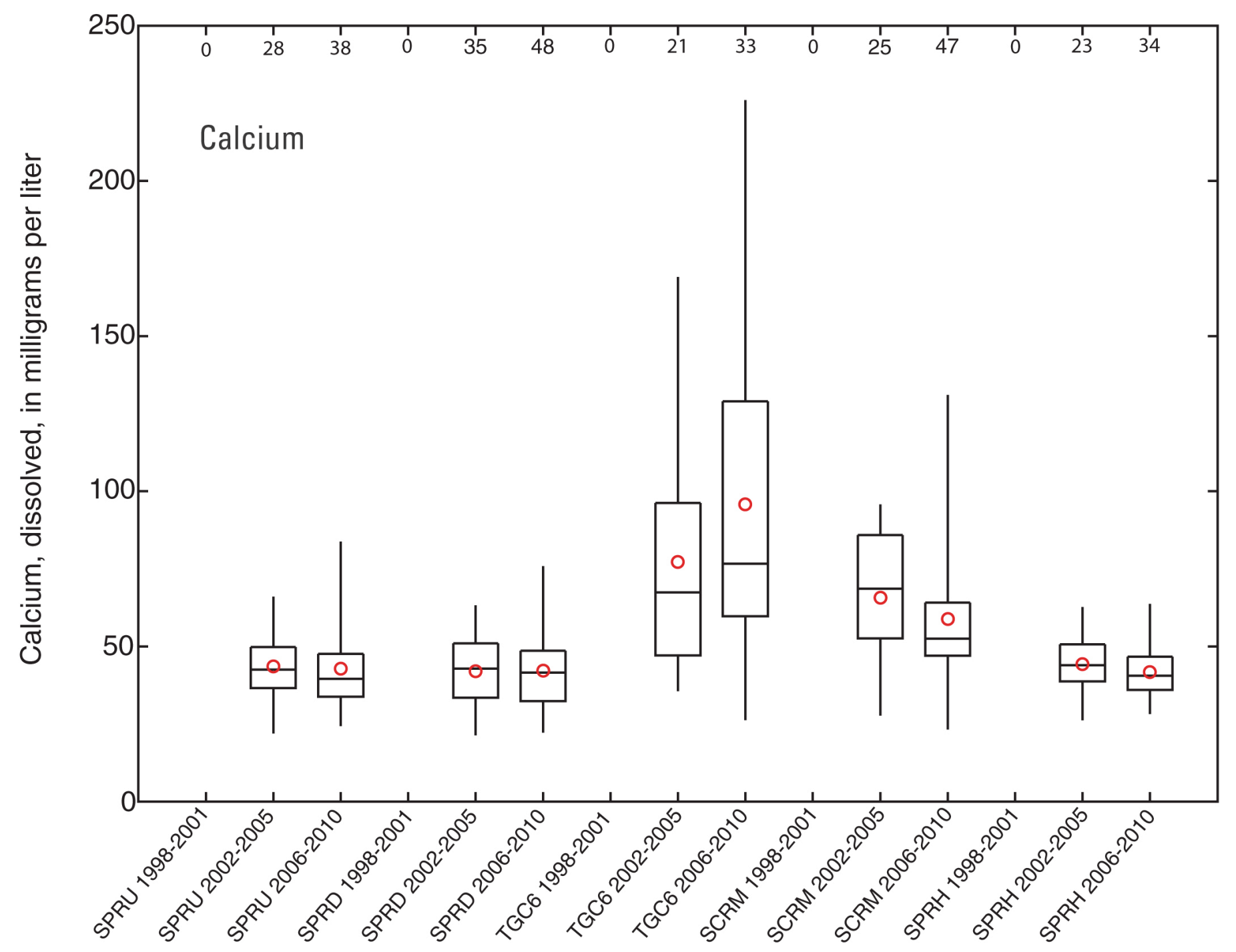

Figure 4. Boxplots showing distribution of water-quality properties and constituents at South Platte River below Union Avenue at Englewood (SPRU), South Platte River at Denver (SPRD), Toll Gate Creek above 6th Avenue at Aurora (TGC6), Sand Creek at mouth near Commerce City (SCRM), and South Platte River at Henderson (SPRH), calendar years 1998-2001, 2002-2005, and 2006-2010. Plotted values and concentrations. Boxplot explanation provided in figure 2.-Continued 


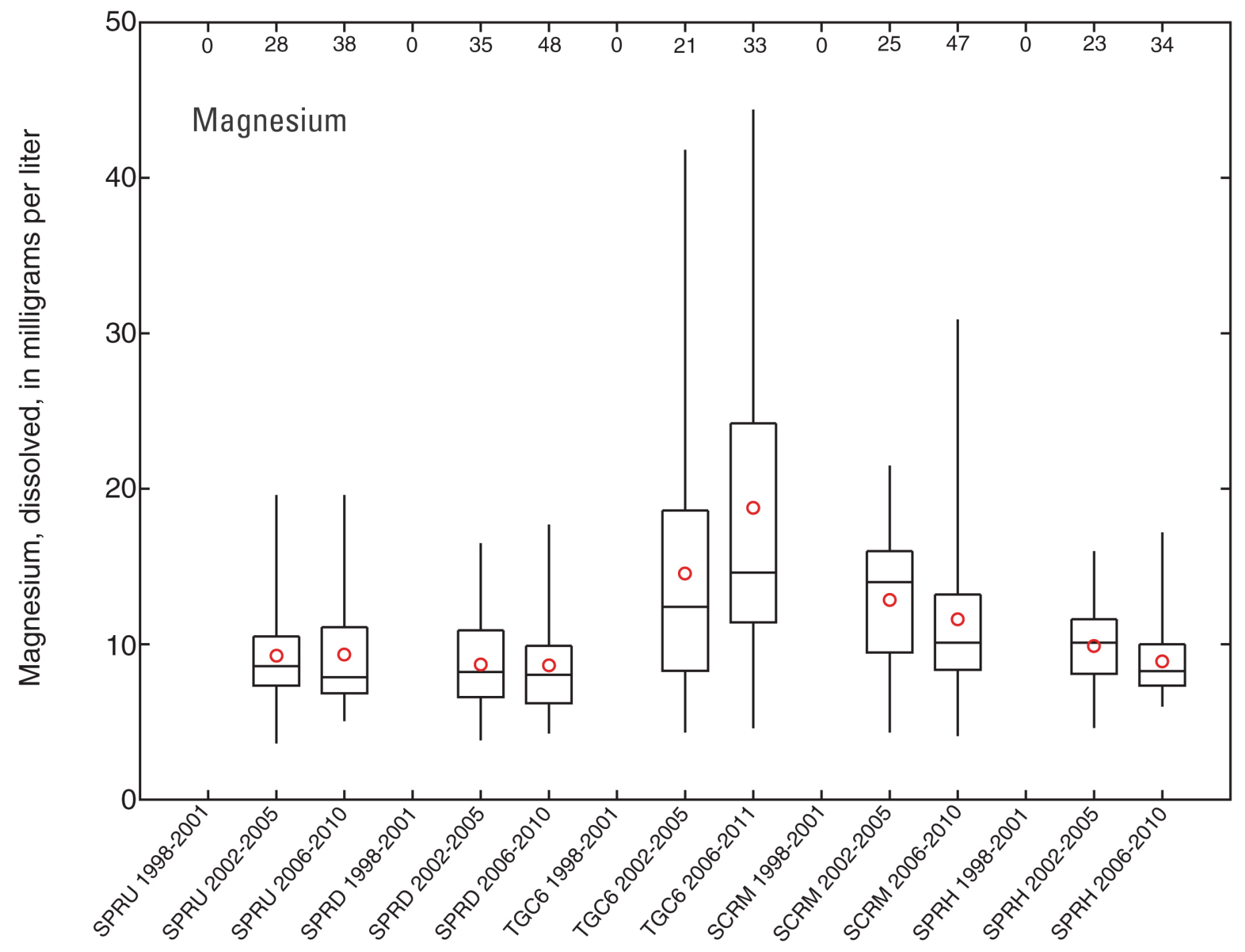

Figure 4. Boxplots showing distribution of water-quality properties and constituents at South Platte River below Union Avenue at Englewood (SPRU), South Platte River at Denver (SPRD), Toll Gate Creek above 6th Avenue at Aurora (TGC6), Sand Creek at mouth near Commerce City (SCRM), and South Platte River at Henderson (SPRH), calendar years 1998-2001, 2002-2005, and 2006-2010. Plotted values and concentrations. Boxplot explanation provided in figure 2.-Continued 


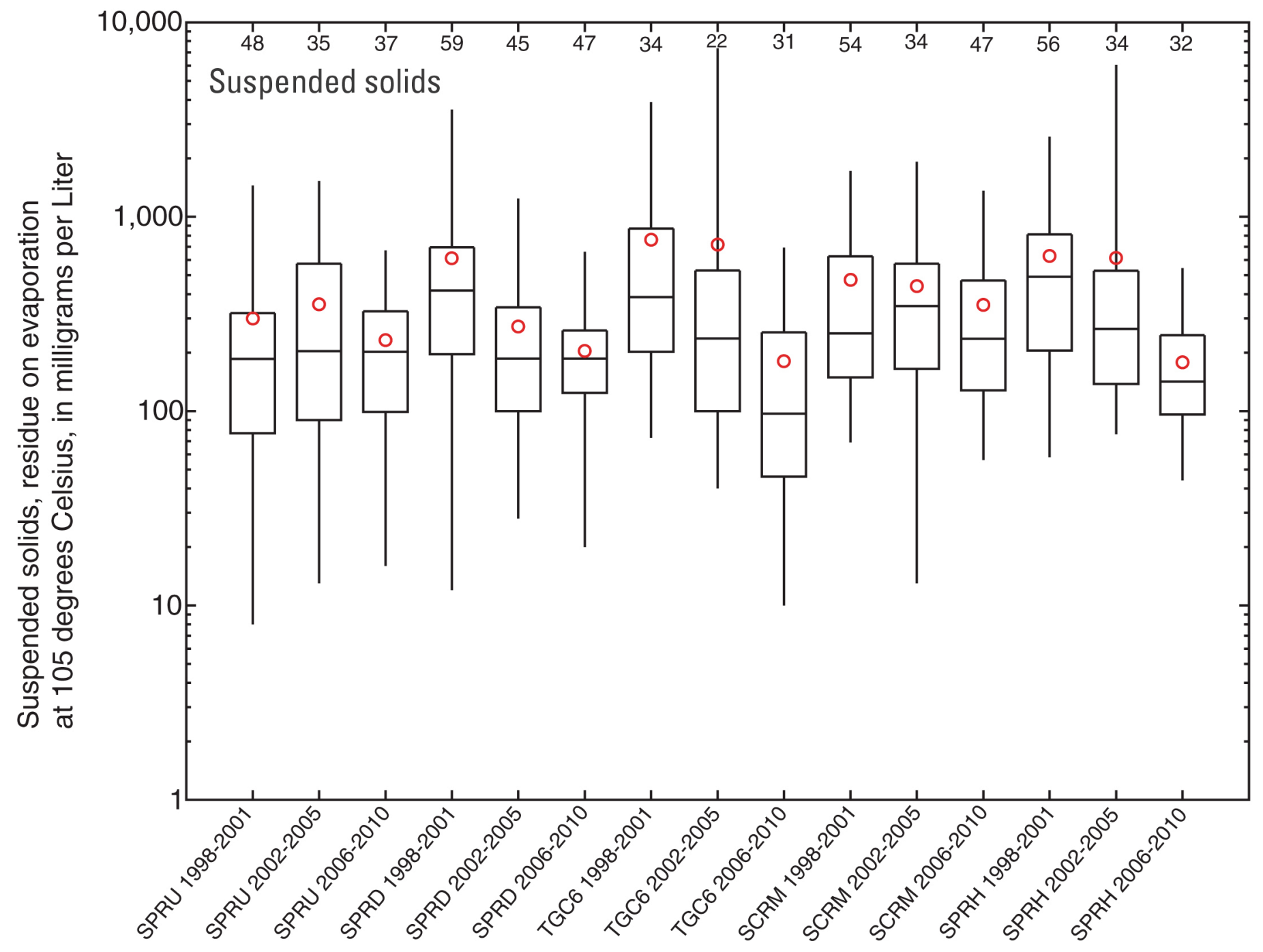

Figure 4. Boxplots showing distribution of water-quality properties and constituents at South Platte River below Union Avenue at Englewood (SPRU), South Platte River at Denver (SPRD), Toll Gate Creek above 6th Avenue at Aurora (TGC6), Sand Creek at mouth near Commerce City (SCRM), and South Platte River at Henderson (SPRH), calendar years 1998-2001, 2002-2005, and 2006-2010. Plotted values and concentrations. Boxplot explanation provided in figure 2.-Continued 


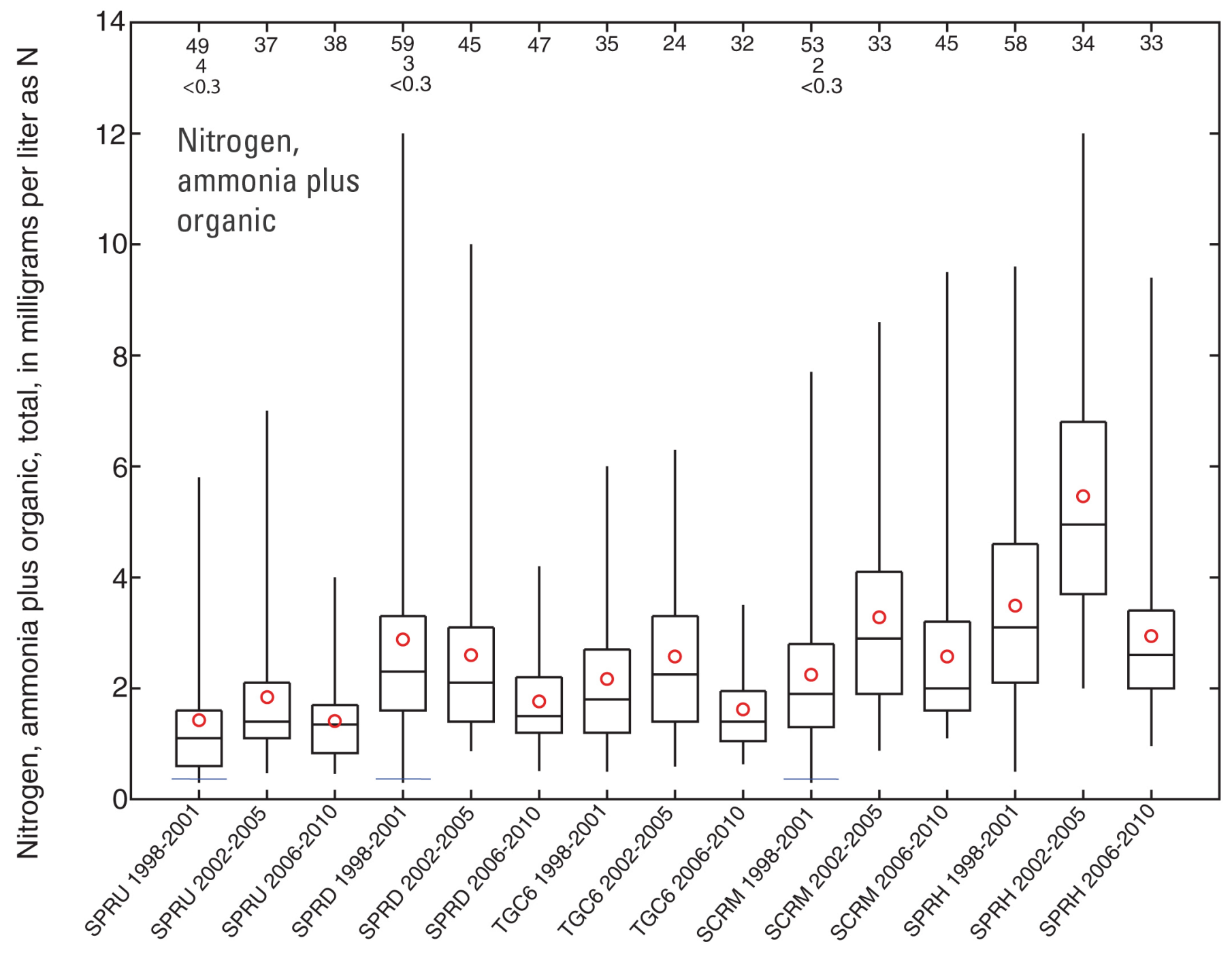

Figure 4. Boxplots showing distribution of water-quality properties and constituents at South Platte River below Union Avenue at Englewood (SPRU), South Platte River at Denver (SPRD), Toll Gate Creek above 6th Avenue at Aurora (TGC6), Sand Creek at mouth near Commerce City (SCRM), and South Platte River at Henderson (SPRH), calendar years 1998-2001, 2002-2005, and 2006-2010. Plotted values and concentrations. Boxplot explanation provided in figure 2.-Continued 


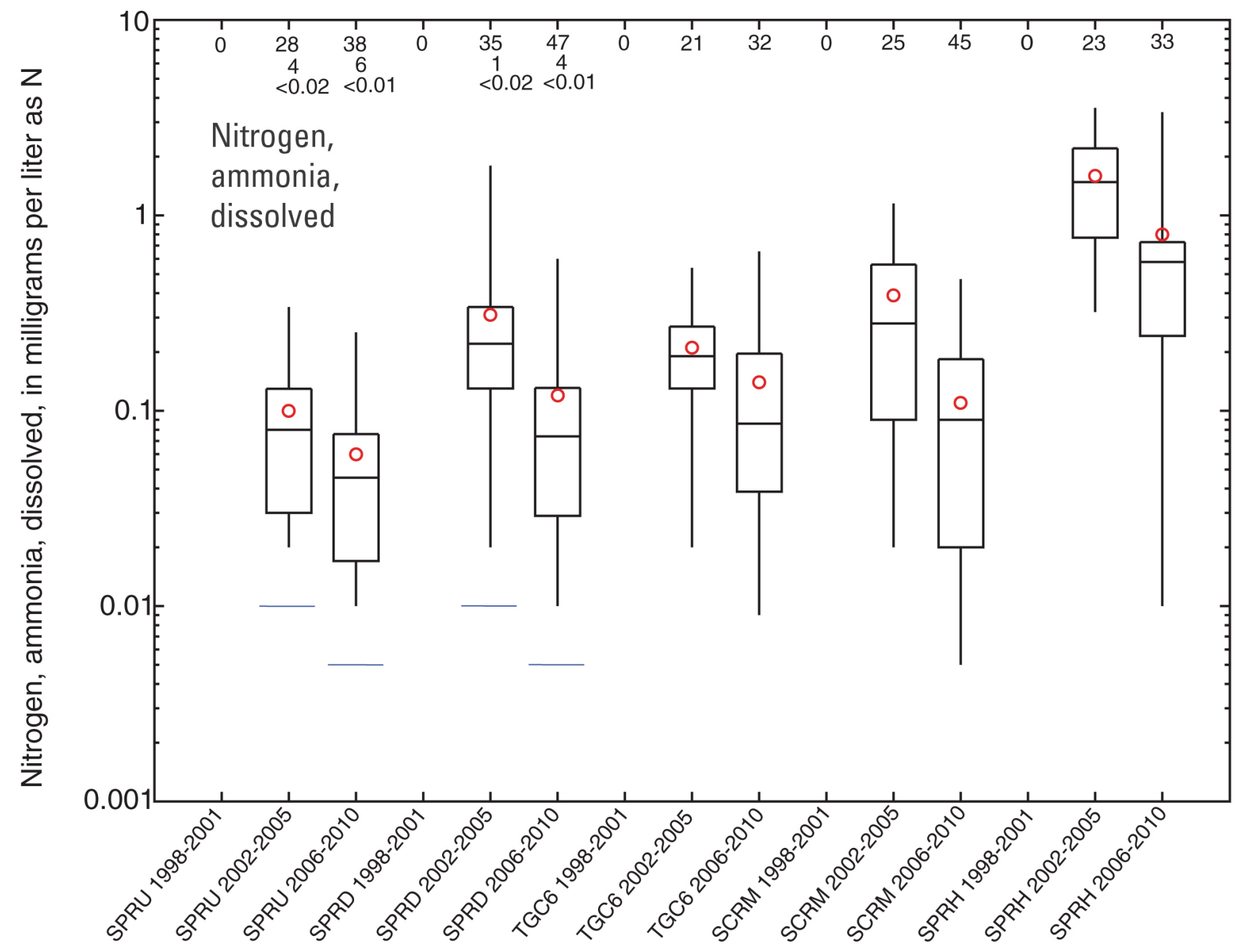

Figure 4. Boxplots showing distribution of water-quality properties and constituents at South Platte River below Union Avenue at Englewood (SPRU), South Platte River at Denver (SPRD), Toll Gate Creek above 6th Avenue at Aurora (TGC6), Sand Creek at mouth near Commerce City (SCRM), and South Platte River at Henderson (SPRH), calendar years 1998-2001, 2002-2005, and 2006-2010. Plotted values and concentrations. Boxplot explanation provided in figure 2.-Continued 


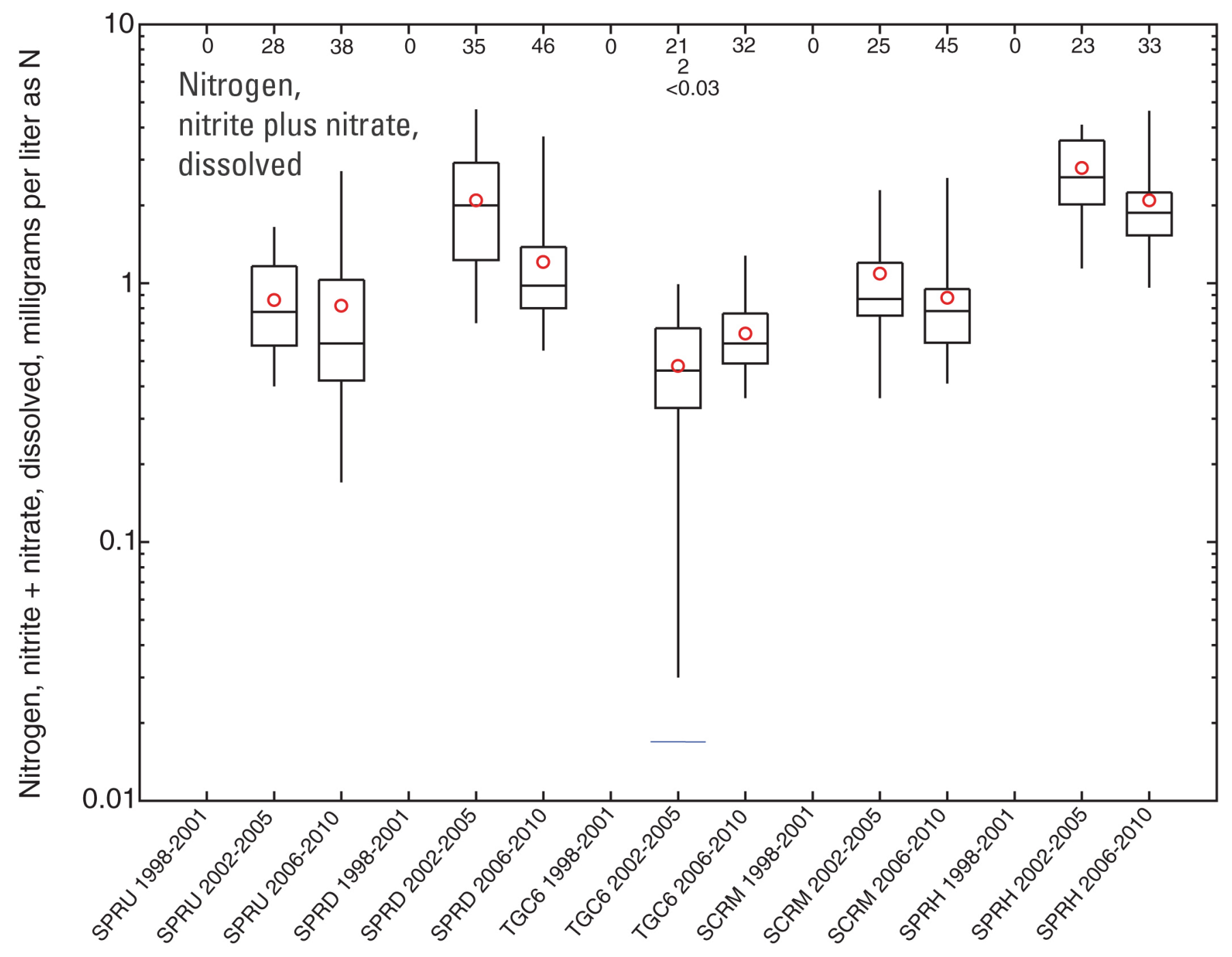

Figure 4. Boxplots showing distribution of water-quality properties and constituents at South Platte River below Union Avenue at Englewood (SPRU), South Platte River at Denver (SPRD), Toll Gate Creek above 6th Avenue at Aurora (TGC6), Sand Creek at mouth near Commerce City (SCRM), and South Platte River at Henderson (SPRH), calendar years 1998-2001, 2002-2005, and 2006-2010. Plotted values and concentrations. Boxplot explanation provided in figure 2.-Continued 


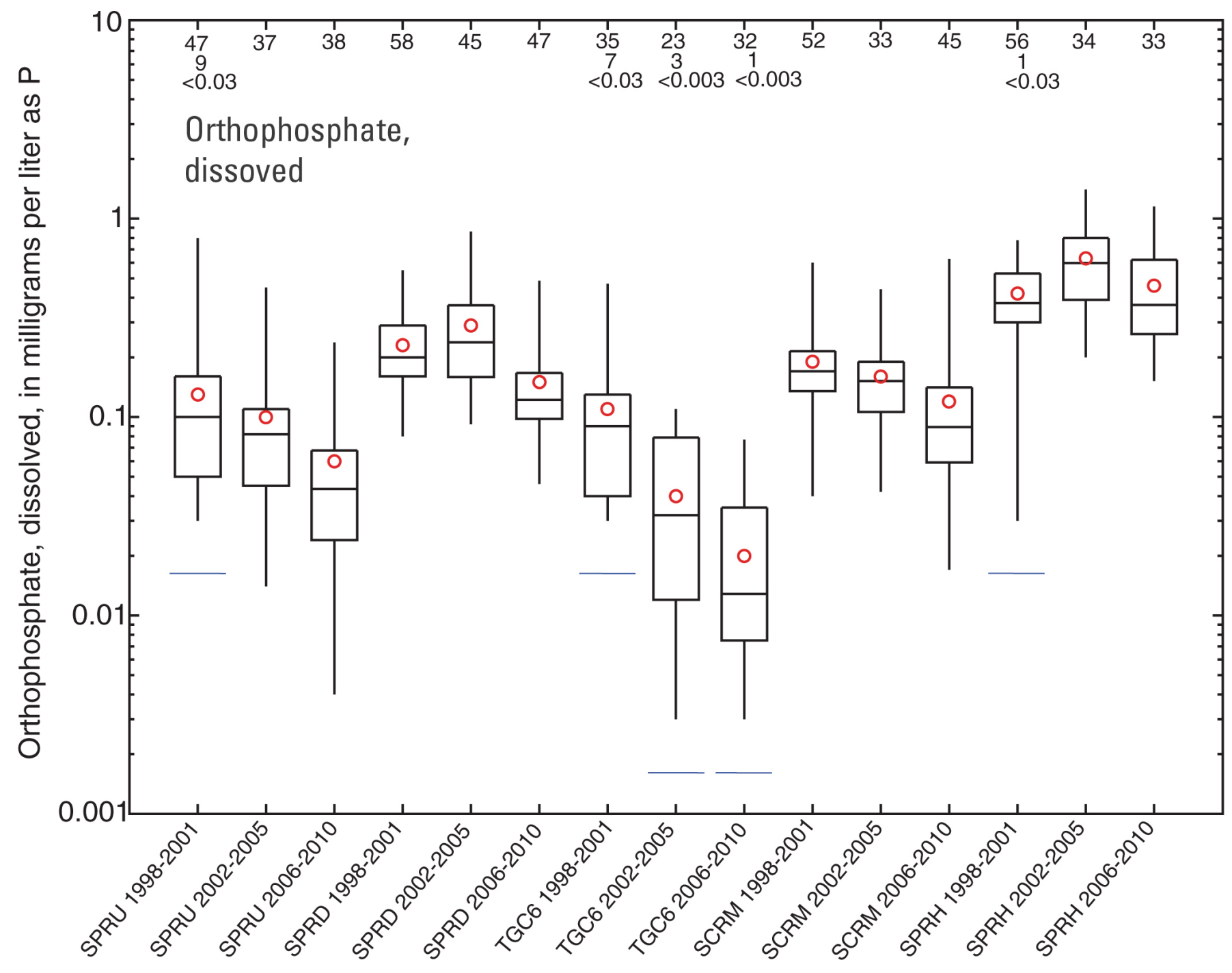

Figure 4. Boxplots showing distribution of water-quality properties and constituents at South Platte River below Union Avenue at Englewood (SPRU), South Platte River at Denver (SPRD), Toll Gate Creek above 6th Avenue at Aurora (TGC6), Sand Creek at mouth near Commerce City (SCRM), and South Platte River at Henderson (SPRH), calendar years 1998-2001, 2002-2005, and 2006-2010. Plotted values and concentrations. Boxplot explanation provided in figure 2.-Continued 


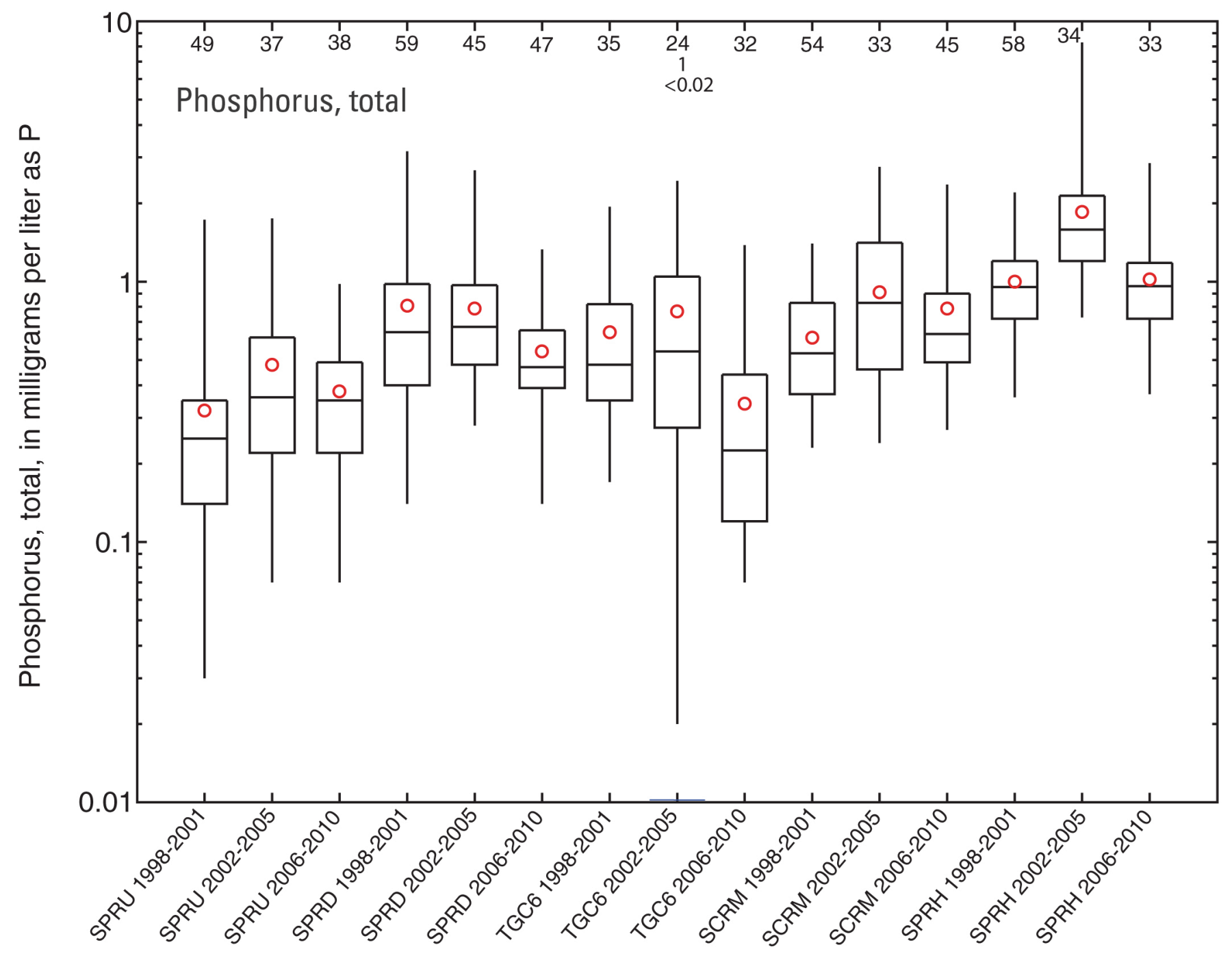

Figure 4. Boxplots showing distribution of water-quality properties and constituents at South Platte River below Union Avenue at Englewood (SPRU), South Platte River at Denver (SPRD), Toll Gate Creek above 6th Avenue at Aurora (TGC6), Sand Creek at mouth near Commerce City (SCRM), and South Platte River at Henderson (SPRH), calendar years 1998-2001, 2002-2005, and 2006-2010. Plotted values and concentrations. Boxplot explanation provided in figure 2.-Continued 


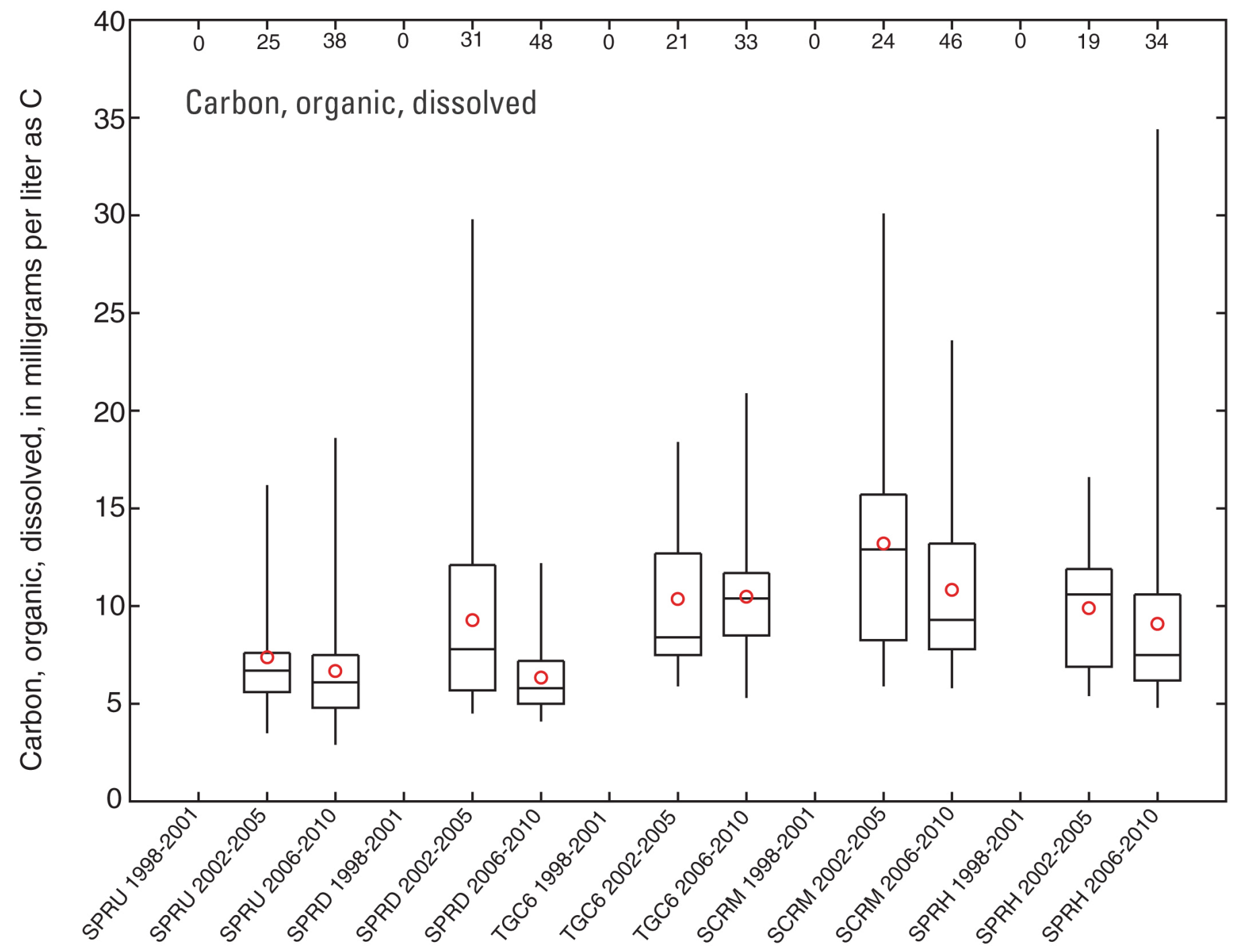

Figure 4. Boxplots showing distribution of water-quality properties and constituents at South Platte River below Union Avenue at Englewood (SPRU), South Platte River at Denver (SPRD), Toll Gate Creek above 6th Avenue at Aurora (TGC6), Sand Creek at mouth near Commerce City (SCRM), and South Platte River at Henderson (SPRH), calendar years 1998-2001, 2002-2005, and 2006-2010. Plotted values and concentrations. Boxplot explanation provided in figure 2.-Continued 


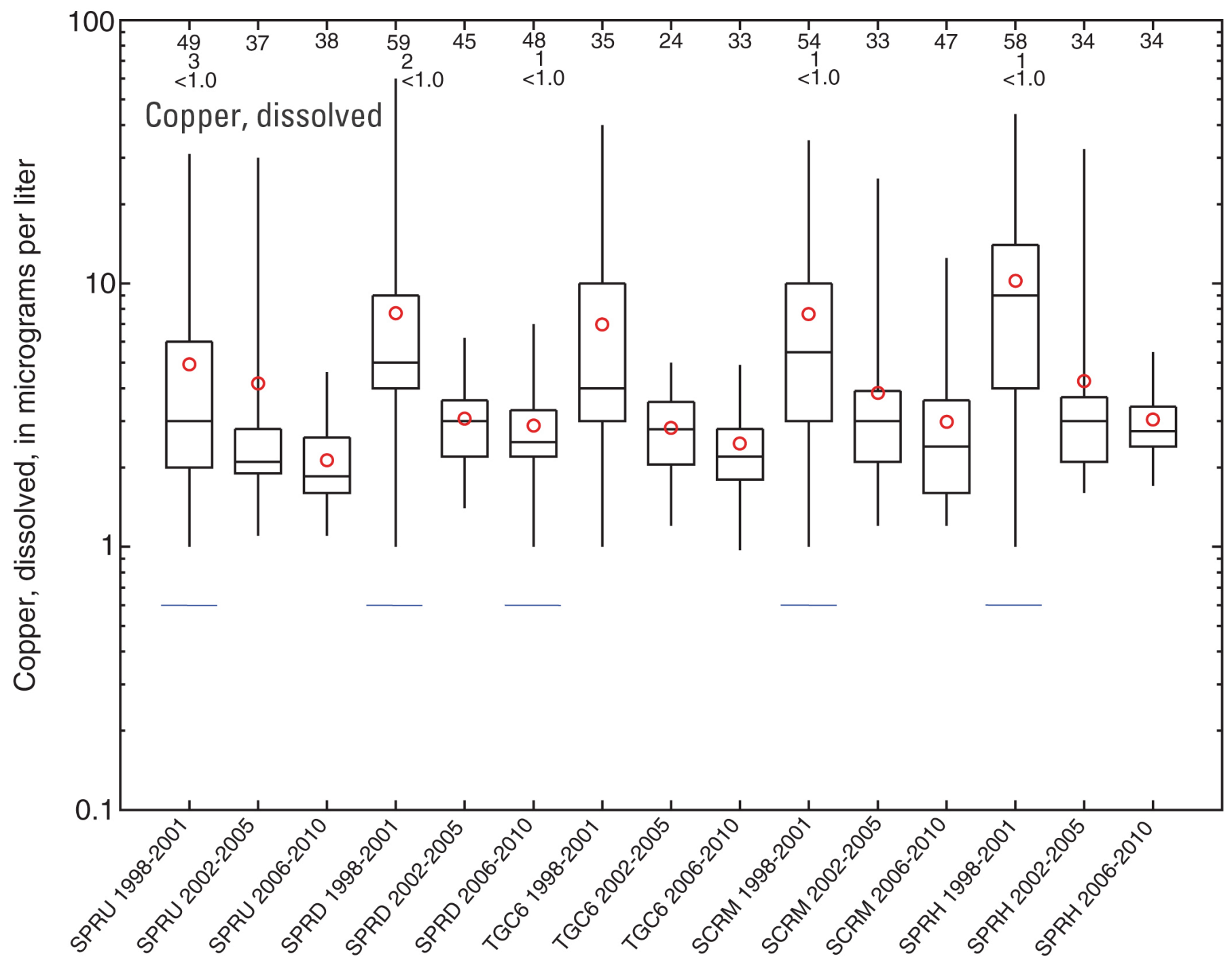

Figure 4. Boxplots showing distribution of water-quality properties and constituents at South Platte River below Union Avenue at Englewood (SPRU), South Platte River at Denver (SPRD), Toll Gate Creek above 6th Avenue at Aurora (TGC6), Sand Creek at mouth near Commerce City (SCRM), and South Platte River at Henderson (SPRH), calendar years 1998-2001, 2002-2005, and 2006-2010. Plotted values and concentrations. Boxplot explanation provided in figure 2.-Continued 


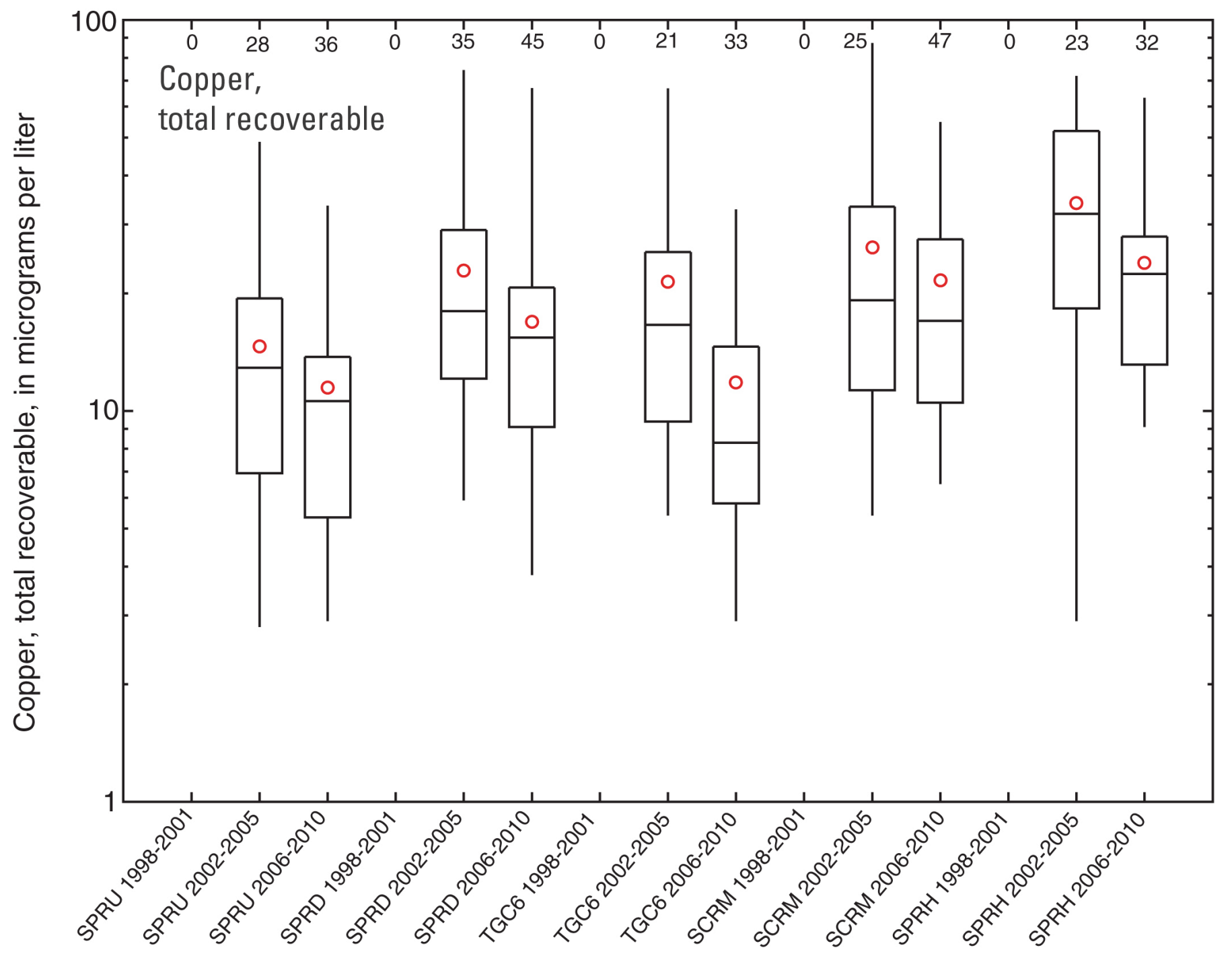

Figure 4. Boxplots showing distribution of water-quality properties and constituents at South Platte River below Union Avenue at Englewood (SPRU), South Platte River at Denver (SPRD), Toll Gate Creek above 6th Avenue at Aurora (TGC6), Sand Creek at mouth near Commerce City (SCRM), and South Platte River at Henderson (SPRH), calendar years 1998-2001, 2002-2005, and 2006-2010. Plotted values and concentrations. Boxplot explanation provided in figure 2.-Continued 


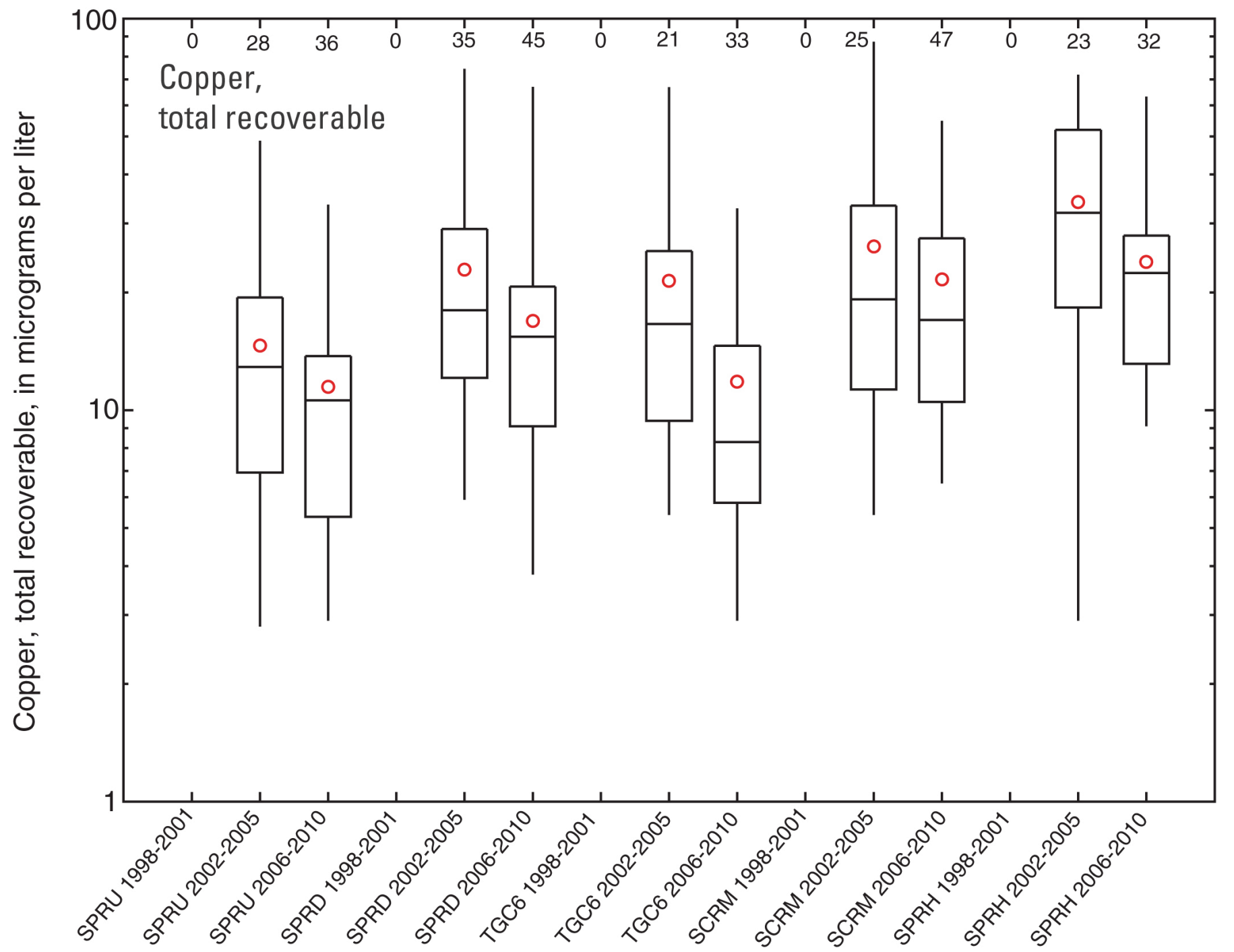

Figure 4. Boxplots showing distribution of water-quality properties and constituents at South Platte River below Union Avenue at Englewood (SPRU), South Platte River at Denver (SPRD), Toll Gate Creek above 6th Avenue at Aurora (TGC6), Sand Creek at mouth near Commerce City (SCRM), and South Platte River at Henderson (SPRH), calendar years 1998-2001, 2002-2005, and 2006-2010. Plotted values and concentrations. Boxplot explanation provided in figure 2.-Continued 


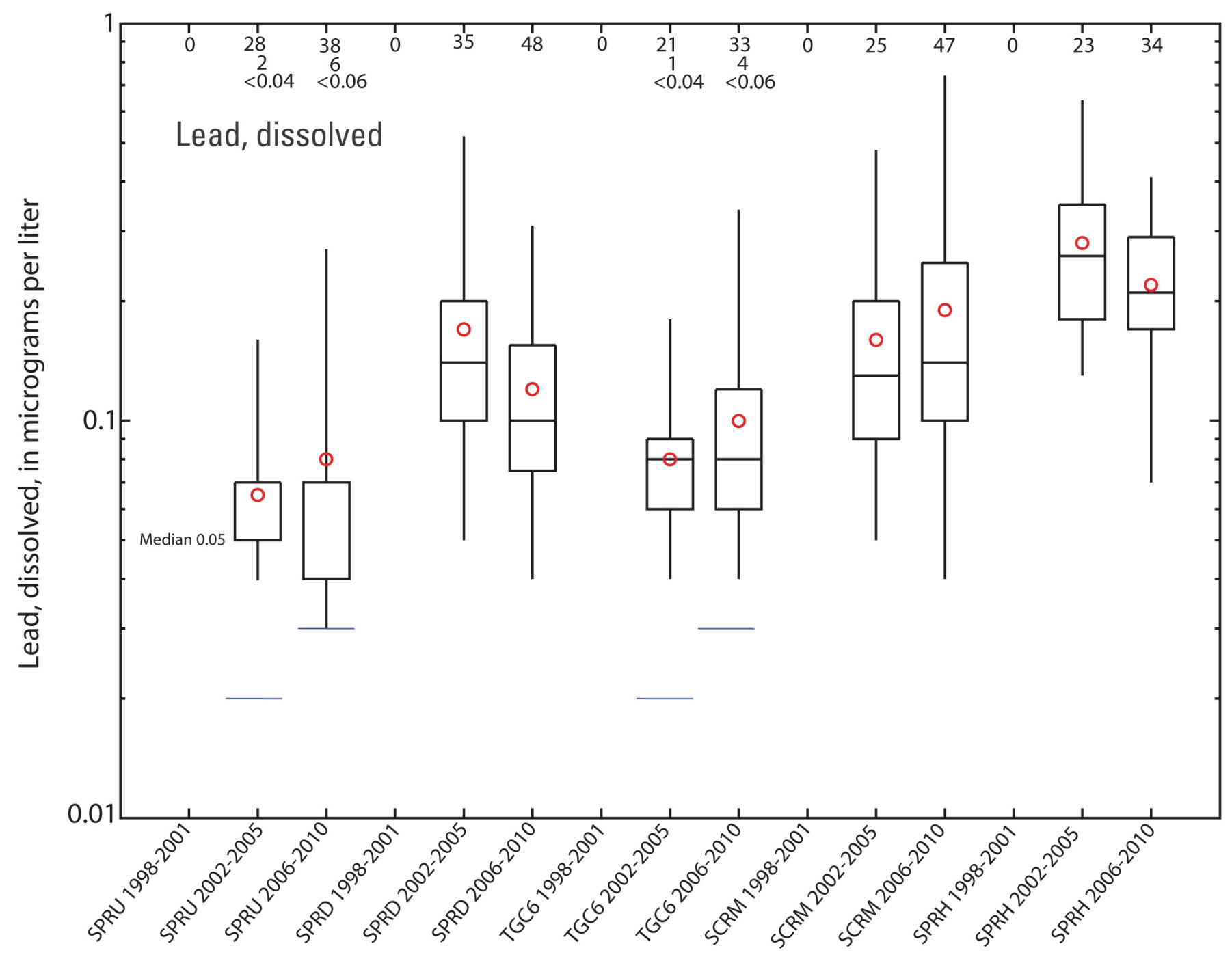

Figure 4. Boxplots showing distribution of water-quality properties and constituents at South Platte River below Union Avenue at Englewood (SPRU), South Platte River at Denver (SPRD), Toll Gate Creek above 6th Avenue at Aurora (TGC6), Sand Creek at mouth near Commerce City (SCRM), and South Platte River at Henderson (SPRH), calendar years 1998-2001, 2002-2005, and 2006-2010. Plotted values and concentrations. Boxplot explanation provided in figure 2.-Continued 


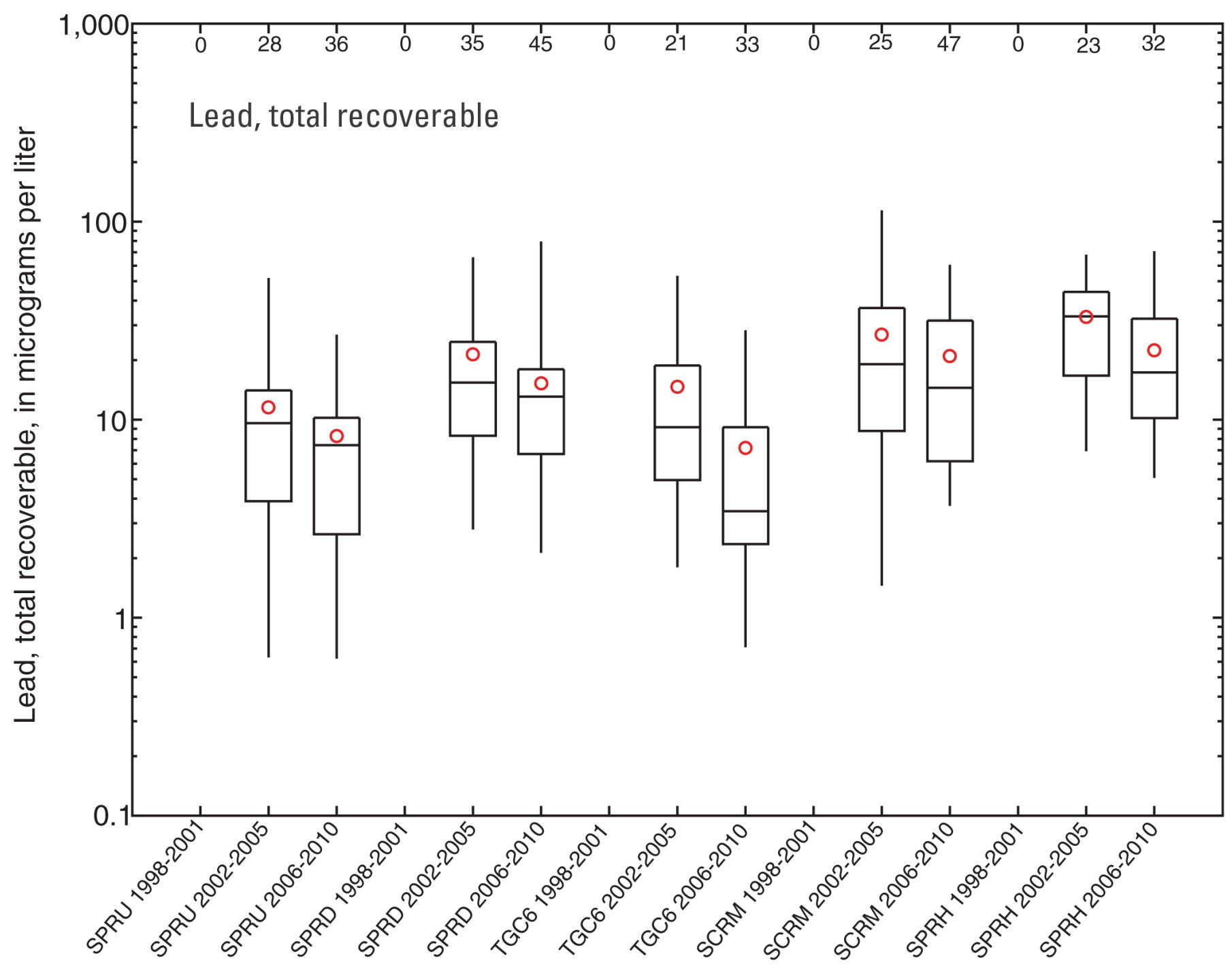

Figure 4. Boxplots showing distribution of water-quality properties and constituents at South Platte River below Union Avenue at Englewood (SPRU), South Platte River at Denver (SPRD), Toll Gate Creek above 6th Avenue at Aurora (TGC6), Sand Creek at mouth near Commerce City (SCRM), and South Platte River at Henderson (SPRH), calendar years 1998-2001, 2002-2005, and 2006-2010. Plotted values and concentrations. Boxplot explanation provided in figure 2.-Continued 


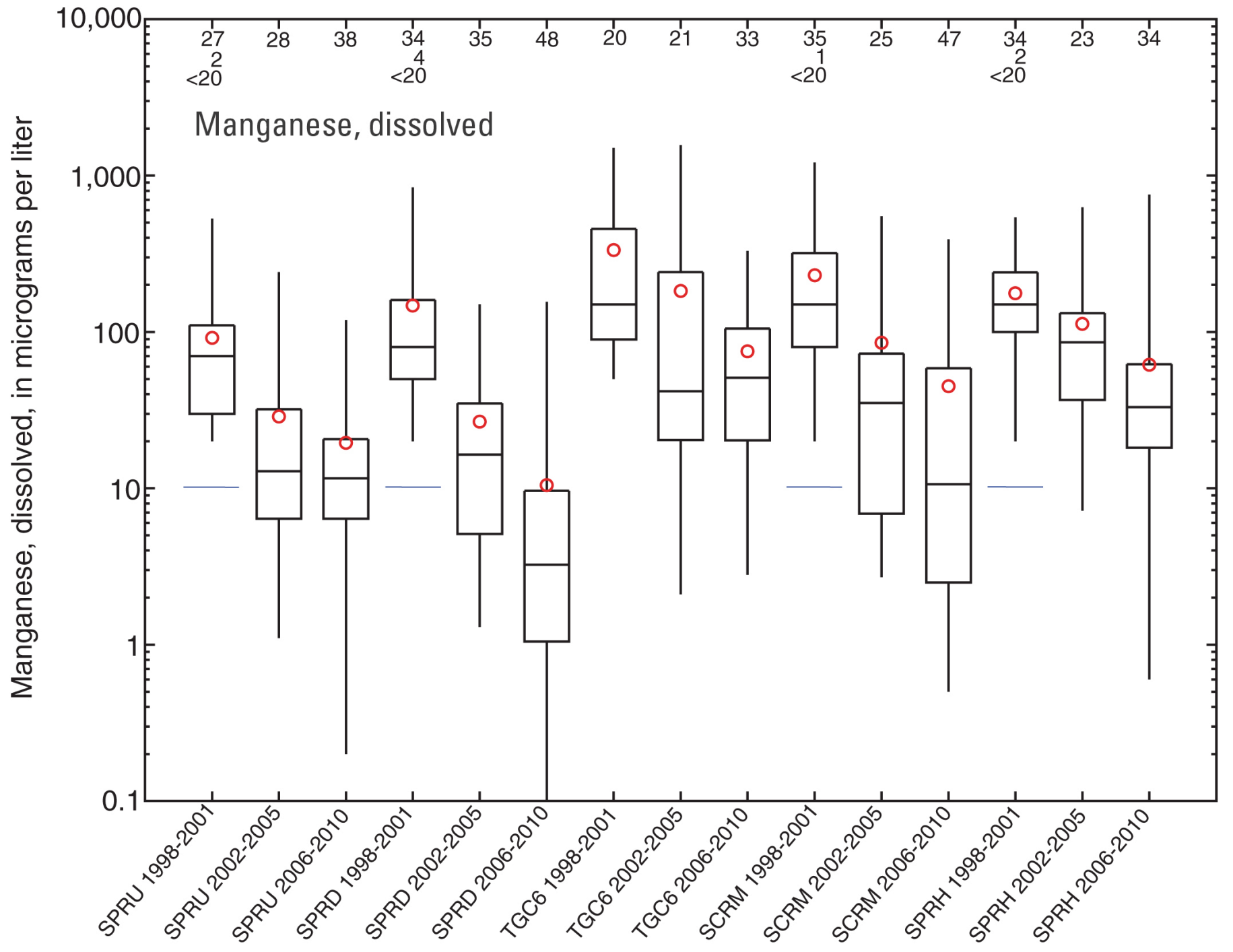

Figure 4. Boxplots showing distribution of water-quality properties and constituents at South Platte River below Union Avenue at Englewood (SPRU), South Platte River at Denver (SPRD), Toll Gate Creek above 6th Avenue at Aurora (TGC6), Sand Creek at mouth near Commerce City (SCRM), and South Platte River at Henderson (SPRH), calendar years 1998-2001, 2002-2005, and 2006-2010. Plotted values and concentrations. Boxplot explanation provided in figure 2.-Continued 


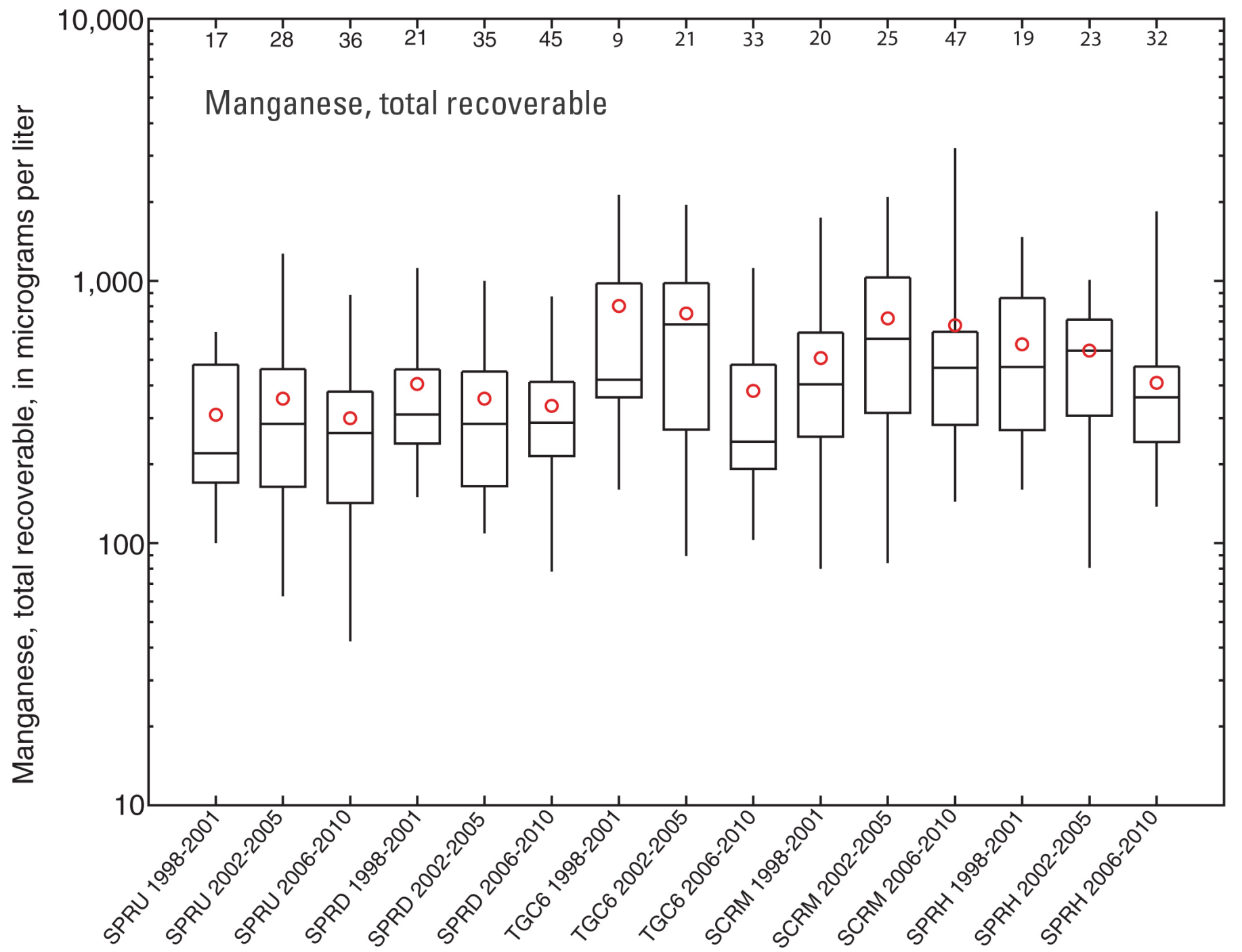

Figure 4. Boxplots showing distribution of water-quality properties and constituents at South Platte River below Union Avenue at Englewood (SPRU), South Platte River at Denver (SPRD), Toll Gate Creek above 6th Avenue at Aurora (TGC6), Sand Creek at mouth near Commerce City (SCRM), and South Platte River at Henderson (SPRH), calendar years 1998-2001, 2002-2005, and 2006-2010. Plotted values and concentrations. Boxplot explanation provided in figure 2.-Continued 


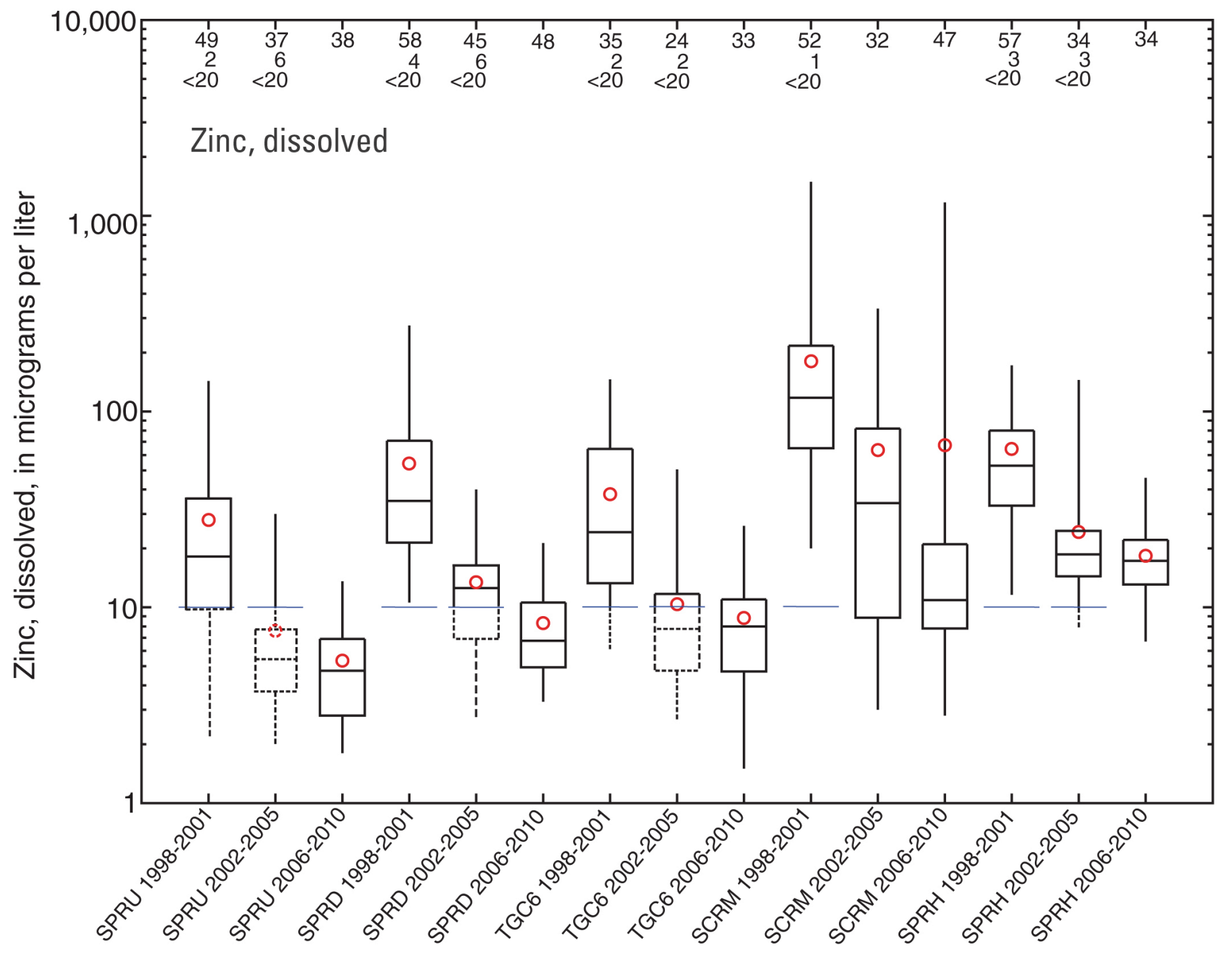

Figure 4. Boxplots showing distribution of water-quality properties and constituents at South Platte River below Union Avenue at Englewood (SPRU), South Platte River at Denver (SPRD), Toll Gate Creek above 6th Avenue at Aurora (TGC6), Sand Creek at mouth near Commerce City (SCRM), and South Platte River at Henderson (SPRH), calendar years 1998-2001, 2002-2005, and 2006-2010. Plotted values and concentrations. Boxplot explanation provided in figure 2.-Continued 


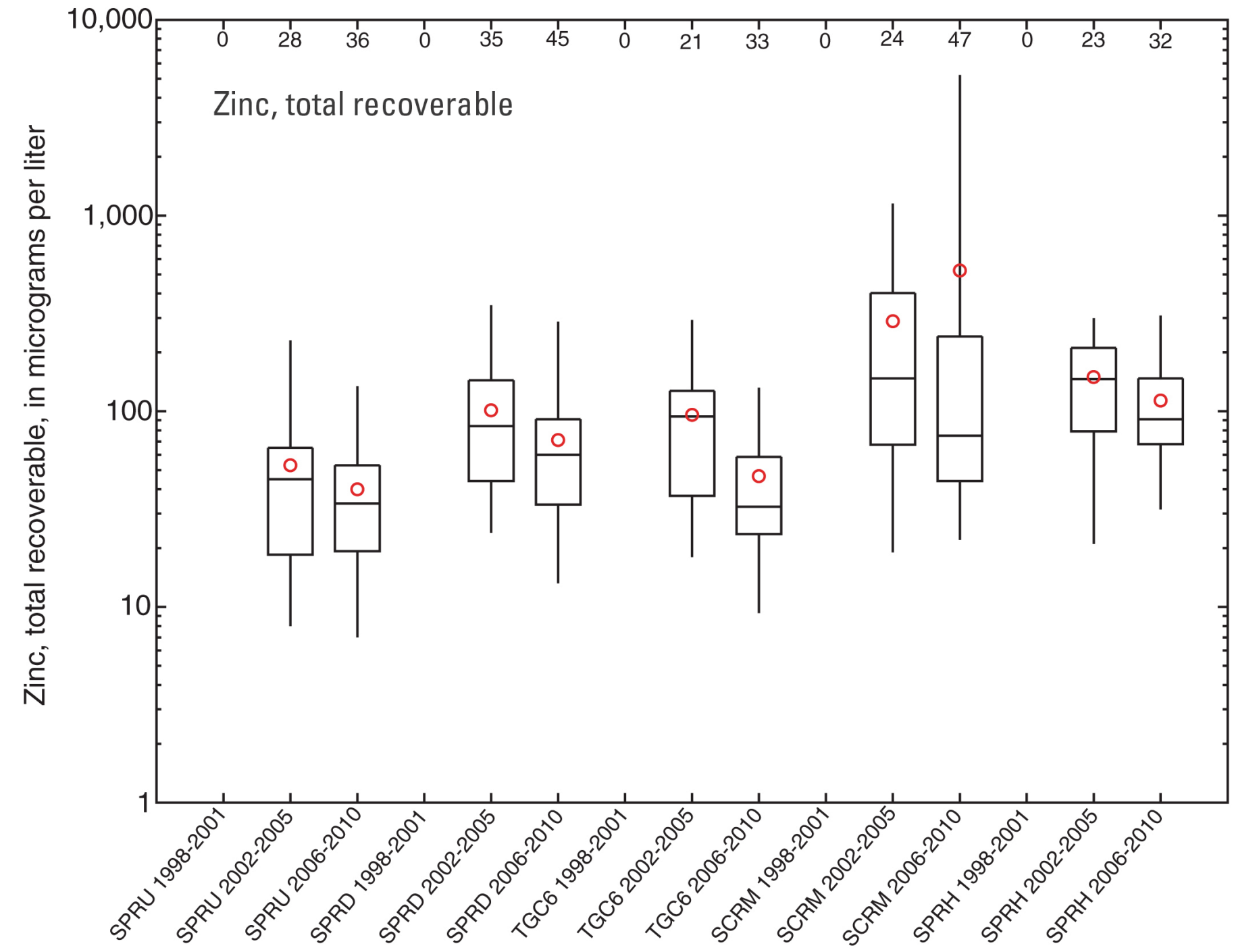

Figure 4. Boxplots showing distribution of water-quality properties and constituents at South Platte River below Union Avenue at Englewood (SPRU), South Platte River at Denver (SPRD), Toll Gate Creek above 6th Avenue at Aurora (TGC6), Sand Creek at mouth near Commerce City (SCRM), and South Platte River at Henderson (SPRH), calendar years 1998-2001, 2002-2005, and 2006-2010. Plotted values and concentrations. Boxplot explanation provided in figure 2. 
The results from laboratory analyses indicate, in general, and particularly for nutrients, that some values and concentrations for water-quality constituents increase with contributing drainage area in the South Platte River, but no well-defined relation was identified between concentration and the amount of urban land cover identified using the U.S. Geological Survey National Land Cover data (table 2; fig. 4; table 7; appendix tables A1-A5). For example, the mean concentration for ammonia plus organic nitrogen is 1.4 milligrams per liter $(\mathrm{mg} / \mathrm{L})$ at Union, $1.8 \mathrm{mg} / \mathrm{L}$ at Denver, and $2.9 \mathrm{mg} / \mathrm{L}$ at Henderson. This pattern corresponds with the size of the local contributing drainage area, which also increases downstream (table 2). Sand Creek, a tributary that flows into the South Platte River between the Denver and Henderson sites, has Toll Gate Creek as tributary. Some values and concentrations of results also increase in a downstream direction from Toll Gate to Sand Creek (fig. 4; table 7; appendix tables A1-A5). For some water-quality constituents, concentrations measured in the tributary streams (Toll Gate Creek and Sand Creek) are higher than concentrations measured in the upstream reach of the South Platte River (Union) (table 7, fig. 4).

\section{Comparison to Colorado Water-Quality Standards}

Results from laboratory analyses of stormwater samples were compared to numeric waterquality standards for $\mathrm{pH}$, Escherichia coli, dissolved nitrite plus nitrate, dissolved copper, lead, manganese, and zinc (Colorado Department of Public Health and Environment, 2011a, 2011b) (table 8). All numeric standards do not apply to all stations. The numeric standards are fixed values for $\mathrm{pH}$, Escherichia coli, dissolved nitrite plus nitrate, and a water-supply-related standard for dissolved manganese. The numeric values for acute and chronic aquatic-life toxicity standards for dissolved copper, lead, manganese (in addition to the fixed standard just mentioned), and zinc are each calculated according to equations published by the CDPHE (Colorado Department of Public Health and Environment, 2011a, 2011b). The calculations for these values, often referred to as "table-value standards," are based on hardness; in this study, the hardness value associated with the composite sample was used in the calculation. 
Table 8. Summary of Colorado water-quality standards and properties and constituents that exceeded Colorado standards for this study, 2006-2010. [--, no data or no standard; ml, milliliter; mg/L, milligrams per liter; $\mu \mathrm{g} / \mathrm{L}$, micrograms per liter; $<$, less than; TVS, table value standards equation; standards from Colorado Department of Public Health and Environment (2011a), 2011b); only data greater than or equal to the reporting level were compared to standards; nitrite plus nitrate concentration is used instead of nitrate for comparison to standard as nitrite concentrations are generally negligible; samples without hardness for trace element standards computation were not included in the exceedance evaluation; water temperature was not available for the computation of ammonia standards for composite samples]

\begin{tabular}{|c|c|c|c|c|c|c|c|c|}
\hline \multirow{2}{*}{ Property or constituent } & \multirow{2}{*}{$\begin{array}{c}\text { Total number } \\
\text { of } \\
\text { samples }\end{array}$} & \multirow{2}{*}{$\begin{array}{c}\text { Total number } \\
\text { of } \\
\text { uncensored } \\
\text { samples }\end{array}$} & \multirow{2}{*}{$\begin{array}{l}\text { Type of } \\
\text { standard }\end{array}$} & \multicolumn{2}{|c|}{$\begin{array}{c}\text { Range of } \\
\text { concentration }\end{array}$} & \multicolumn{2}{|c|}{ Standards } & \multirow{2}{*}{$\begin{array}{l}\text { Number of } \\
\text { uncensored } \\
\text { sample } \\
\text { exceedances }\end{array}$} \\
\hline & & & & Minimum & Maximum & Chronic & Acute & \\
\hline \multicolumn{9}{|c|}{ South Platte River below Union at Englewood } \\
\hline $\mathrm{pH}$, lab, standard units & 38 & 38 & Fixed & 6.9 & 8.4 & -- & 6.5 to 9.0 & 0 \\
\hline Escherichia coli, colonies $/ 100 \mathrm{ml}$ & 4 & 0 & Fixed & 20 & 11,000 & -- & 120 & 3 \\
\hline Nitrate, dissolved, $\mathrm{mg} / \mathrm{L}$ & 38 & 38 & Fixed & 0.17 & 2.71 & -- & 10 & 0 \\
\hline \multirow[t]{2}{*}{ Copper, dissolved, $\mu \mathrm{g} / \mathrm{L}$} & 38 & 38 & TVS acute & 1.1 & 4.6 & -- & 33 to 109 & 0 \\
\hline & 38 & 38 & TVS chronic & 1.1 & 4.6 & 26 to 77 & -- & 0 \\
\hline \multirow[t]{2}{*}{ Lead, dissolved, $\mu \mathrm{g} / \mathrm{L}$} & 38 & 32 & TVS acute & 0.03 & 0.27 & -- & 35 to 135 & 0 \\
\hline & 38 & 32 & TVS chronic & 0.03 & 0.27 & 0.6 to 2.2 & -- & 0 \\
\hline \multirow[t]{3}{*}{ Manganese, dissolved, $\mu \mathrm{g} / \mathrm{L}$} & 38 & 38 & TVS acute & 0.2 & 119 & -- & 37 to 57 & 3 \\
\hline & 38 & 38 & TVS chronic & 0.2 & 119 & 31 to 47 & -- & 4 \\
\hline & 38 & 38 & Fixed chronic & 0.2 & 119 & 190 & -- & 0 \\
\hline \multirow[t]{2}{*}{ Zinc, dissolved, $\mu \mathrm{g} / \mathrm{L}$} & 38 & 38 & TVS acute & 1.8 & 1.8 & -- & 103 to 304 & 0 \\
\hline & 38 & 38 & TVS chronic & 13.6 & 13.6 & 91 to 269 & -- & 0 \\
\hline \multicolumn{9}{|c|}{ South Platte River at Denver } \\
\hline $\mathrm{pH}$, lab, standard units & 48 & 48 & Fixed & 6.6 & 8.0 & -- & 6.5 to 9.0 & 0 \\
\hline Escherichia coli, colonies/100ml & 4 & 0 & Fixed & 110 & 23,000 & & 120 & 3 \\
\hline Nitrate, dissolved, $\mathrm{mg} / \mathrm{L}$ & 46 & 46 & Fixed & 0.60 & 3.7 & -- & 10 & 0 \\
\hline \multirow[t]{2}{*}{ Copper, dissolved, $\mu \mathrm{g} / \mathrm{L}$} & 48 & 47 & TVS acute & 1.5 & 7.0 & -- & 11 to 35 & 0 \\
\hline & 48 & 47 & TVS chronic & 1.5 & 7.0 & 30 to 96 & -- & 0 \\
\hline \multirow[t]{2}{*}{ Lead, dissolved, $\mu \mathrm{g} / \mathrm{L}$} & 48 & 48 & TVS acute & 0.04 & 0.31 & -- & 31 to 116 & 0 \\
\hline & 48 & 48 & TVS chronic & 0.04 & 0.31 & $\begin{array}{c}0.5 \text { to } \\
1.9\end{array}$ & -- & 0 \\
\hline \multirow[t]{3}{*}{ Manganese, dissolved, $\mu \mathrm{g} / \mathrm{L}$} & 48 & 48 & TVS acute & 0.1 & 156 & -- & 36 to 54 & 2 \\
\hline & 48 & 48 & TVS chronic & 0.1 & 156 & 30 to 45 & -- & 2 \\
\hline & 48 & 48 & Fixed chronic & 0.1 & 156 & 190 & -- & 0 \\
\hline \multirow[t]{2}{*}{ Zinc, dissolved, $\mu \mathrm{g} / \mathrm{L}$} & 48 & 48 & TVS acute & 3.3 & 21.3 & -- & 363 to 1,390 & 0 \\
\hline & 48 & 48 & TVS chronic & 3.3 & 21.3 & 84 to 238 & -- & 0 \\
\hline
\end{tabular}


Table 8. Summary of Colorado water-quality standards and properties and constituents that exceeded Colorado standards for this study, 2006-2010.-Continued [--, no data or no standard; ml, milliliter; mg/L, milligrams per liter; $\mu \mathrm{g} / \mathrm{L}$, micrograms per liter; <, less than; TVS, table value standards equation; standards from Colorado Department of Public Health and Environment (2011a), 2011b); only data greater than or equal to the reporting level were compared to standards; nitrite plus nitrate concentration is used instead of nitrate for comparison to standard as nitrite concentrations are generally negligible; samples without hardness for trace element standards computation were not included in the exceedance evaluation; water temperature was not available for the computation of ammonia standards for composite samples]

\begin{tabular}{|c|c|c|c|c|c|c|c|c|}
\hline \multicolumn{9}{|c|}{ Toll Gate Creek above 6th Avenue at Aurora } \\
\hline $\mathrm{pH}$, lab, standard units & 33 & 33 & Fixed & 7.4 & 8.0 & -- & 6.5 to 9.0 & 0 \\
\hline Escherichia coli, colonies $/ 100 \mathrm{ml}$ & 3 & 0 & Fixed & 330 & 3,300 & -- & 120 & 3 \\
\hline Nitrate, dissolved, $\mathrm{mg} / \mathrm{L}$ & 32 & 32 & Fixed & 0.009 & 0.66 & -- & 10 & 0 \\
\hline \multirow[t]{2}{*}{ Copper, dissolved, $\mu \mathrm{g} / \mathrm{L}$} & 33 & 33 & TVS acute & 0.97 & 4.9 & -- & 13 to 99 & 0 \\
\hline & 33 & 33 & TVS chronic & 0.97 & 4.9 & 10 to 64 & -- & 0 \\
\hline \multirow[t]{2}{*}{ Lead, dissolved, $\mu \mathrm{g} / \mathrm{L}$} & 33 & 29 & TVS acute & 0.04 & 0.34 & -- & 58 to 352 & 0 \\
\hline & 33 & 29 & TVS chronic & 0.04 & 0.34 & 0.93 to 5.7 & -- & 0 \\
\hline \multirow[t]{2}{*}{ Manganese, dissolved, $\mu \mathrm{g} / \mathrm{L}$} & 33 & 33 & TVS acute & 3 & 330 & -- & 38 to 78 & 15 \\
\hline & 33 & 33 & TVS chronic & 3 & 330 & 31 to 64 & -- & 17 \\
\hline \multirow[t]{2}{*}{ Zinc, dissolved, $\mu \mathrm{g} / \mathrm{L}$} & 33 & 33 & TVS acute & 1.5 & 26.1 & -- & 419 to 4,620 & 0 \\
\hline & 33 & 33 & TVS chronic & 1.5 & 26.1 & 94 to 603 & -- & 0 \\
\hline \multicolumn{9}{|c|}{ Sand Creek at mouth near Commerce City } \\
\hline $\mathrm{pH}$, lab, standard units & 47 & 47 & Fixed & 7.3 & 8.0 & -- & 6.5 to 9.0 & 0 \\
\hline Escherichia coli, colonies $/ 100 \mathrm{ml}$ & 3 & 0 & Fixed & 790 & 4,900 & -- & 120 & 3 \\
\hline Nitrate, dissolved, $\mathrm{mg} / \mathrm{L}$ & 45 & 45 & Fixed & 0.41 & 2.6 & -- & 10 & 0 \\
\hline \multirow[t]{2}{*}{ Copper, dissolved, $\mu \mathrm{g} / \mathrm{L}$} & 47 & 47 & TVS acute & 1.2 & 12.5 & -- & 29 to 161 & 0 \\
\hline & 47 & 47 & TVS chronic & 1.2 & 12.5 & 23 to 110 & -- & 0 \\
\hline \multirow[t]{2}{*}{ Lead, dissolved, $\mu \mathrm{g} / \mathrm{L}$} & 47 & 47 & TVS acute & 0.04 & 0.74 & -- & 32 to 215 & 0 \\
\hline & 47 & 47 & TVS chronic & 0.04 & 0.74 & 0.51 to 3.46 & -- & 0 \\
\hline \multirow[t]{2}{*}{ Manganese, dissolved, $\mu \mathrm{g} / \mathrm{L}$} & 47 & 47 & TVS acute & 0.5 & 391 & -- & 36 to 66 & 13 \\
\hline & 47 & 47 & TVS chronic & 0.5 & 391 & 30 to 54 & -- & 15 \\
\hline \multirow[t]{2}{*}{ Zinc, dissolved, $\mu \mathrm{g} / \mathrm{L}$} & 47 & 47 & TVS acute & 2.8 & 1,170 & -- & 366 to 2,680 & 1 \\
\hline & 47 & 47 & TVS chronic & 2.8 & 1,170 & 85 to 395 & -- & 4 \\
\hline \multicolumn{9}{|c|}{ South Platte River at Henderson } \\
\hline $\mathrm{pH}$, lab, standard units & 34 & 34 & Fixed & 6.6 & 7.7 & -- & 6.5 to 9.0 & 0 \\
\hline Escherichia coli, colonies $/ 100 \mathrm{ml}$ & 3 & 0 & Fixed & 310 & 23,000 & -- & 120 & 3 \\
\hline Nitrate, dissolved, mg/L & 33 & 33 & Fixed & 0.96 & 4.6 & -- & 10 & 0 \\
\hline \multirow[t]{2}{*}{ Copper, dissolved, $\mu \mathrm{g} / \mathrm{L}$} & 34 & 34 & TVS acute & 1.7 & 5.5 & -- & 33 to 74 & 0 \\
\hline & 34 & 34 & TVS chronic & 1.7 & 5.5 & 25 to 53 & -- & 0 \\
\hline \multirow[t]{2}{*}{ Lead, dissolved, $\mu \mathrm{g} / \mathrm{L}$} & 34 & 34 & TVS acute & 0.07 & 0.41 & -- & 41 to 104 & 0 \\
\hline & 34 & 34 & TVS chronic & 0.07 & 0.41 & 0.66 to 1.67 & -- & 0 \\
\hline \multirow[t]{3}{*}{ Manganese, dissolved, $\mu \mathrm{g} / \mathrm{L}$} & 34 & 34 & TVS acute & 0.6 & 757 & -- & 39 to 52 & 13 \\
\hline & 34 & 34 & TVS chronic & 0.6 & 757 & 32 to 43 & -- & 16 \\
\hline & 34 & 34 & Fixed chronic & 0.6 & 757 & 400 & -- & 1 \\
\hline \multirow[t]{2}{*}{ Zinc, dissolved, $\mu \mathrm{g} / \mathrm{L}$} & 34 & 34 & TVS acute & 6.7 & 46 & -- & 476 to 1,240 & 0 \\
\hline & 34 & 34 & TVS chronic & 6.7 & 46 & 104 to 218 & -- & 0 \\
\hline
\end{tabular}


A summary of results from 2006-2010 stormwater samples that did not meet (exceeded) CDPHE water-quality standards (Colorado Department of Public Health and Environment, 2011a, $2011 \mathrm{~b}$ ) is presented in table 8 for individual stations. The results indicate few exceptions to standards except for dissolved manganese, dissolved zinc, and Escherichia coli. Stormwater collected at Union had about 10 percent acute or chronic dissolved manganese exceedances in samples; samples collected at Denver had less than 5 percent acute or chronic dissolved manganese exceedances (table 8). In contrast, samples collected at Toll Gate, Sand Creek, and Henderson, each had about 30 to 50 percent exceedances of both acute and chronic dissolved manganese standards. Of the samples collected at Sand Creek, 1 sample exceeded the acute standard and 4 samples exceeded the chronic standard for dissolved zinc (table 8), but no samples collected from the other sites exceeded either standard for zinc. Almost all samples of stormwater analyzed for Escherichia coli exceeded the Colorado numeric standards (table 8). A numerical standard for fecal coliform is no longer applicable as of 2004 (Colorado Department of Health and Environment, 2006).

\section{Evaluation of Stormwater Quality between 2006-2010 and 2002-2005}

The water quality of stormwater samples collected in this study is evaluated in this section by using the Mann-Whitney rank-sum test, which is a nonparametric statistical test (Helsel and Hirsch, 1992). The evaluation compares 2006-2010 results to 2002-2005 results. Previous reports (Bossong and others, 2005; Bossong and Fleming, 2008) grouped data by water years, but this report groups and analyzes data by calendar year.

\section{Statistics}

The distribution of data from stormwater samples collected during 2006-2010 was compared to the corresponding distribution of 2002-2005 data to determine if water quality changed between periods. In this report, an upward trend indicates increasing values or concentrations, and a downward trend indicates decreasing values or concentrations (table 9). Trends in stormwater quality also are illustrated in boxplots for each of the five sites (fig. 4) and presented in the statistics of table 7 and appendix tables A1-A5. Although boxplots also are presented for 1998-2001 data (Bossong and others, 2005), the statistical comparisons and trend analysis with the 2002-2006 data were made in Bossong and Fleming (2008) and are not repeated herein. 
Table 9. Mann-Whitney test of differences between distributions of water-quality values and concentrations in stormwater samples collected in 20022005 and $2006-2010$ at all sites.

[n, number of samples, each time period separated by a comma; shaded values indicate statistical significance for this report with a p-value less than or equal to $0.1000 ; \mathrm{mg} / \mathrm{L}$, milligrams per liter; $\mu \mathrm{g} / \mathrm{L}$, micrograms per liter; ${ }^{\circ} \mathrm{C}$, degrees Celsius; $\mu \mathrm{S} / \mathrm{cm}$, microsiemens per centimeter at $25^{\circ} \mathrm{C} ; \mathrm{CaCO}_{3}$, calcium carbonate; cm, centimeter; $\mathrm{N}$, nitrogen; $\mathrm{P}$, phosphorus; $\mathrm{C}$, carbon; MPN, most probable number]

\begin{tabular}{|c|c|c|c|c|c|}
\hline \multirow[b]{2}{*}{ Property or constituent } & \multicolumn{5}{|c|}{ South Platte River below Union Avenue } \\
\hline & $\mathrm{n}$ & $\begin{array}{l}\text { Median value or } \\
\text { concentration } \\
2002-2005\end{array}$ & $\begin{array}{c}\text { Median value or } \\
\text { concentration } \\
2006-2010\end{array}$ & p-value & Trend \\
\hline Streamflow, mean, in $\mathrm{ft}^{3} / \mathrm{s}$ & 37,38 & 154 & 346 & 0.0059 & Upward \\
\hline $\mathrm{pH}$, lab & 37,38 & 7.5 & 7.7 & 0.0018 & Upward \\
\hline Specific conductance, field, $\mu \mathrm{S} / \mathrm{cm}$ at $25^{\circ} \mathrm{C}$ & 31,38 & 478 & 410 & 0.4509 & None \\
\hline Hardness, as $\mathrm{CaCO}_{3}$, in $\mathrm{mg} / \mathrm{L}$ & 37,38 & 155 & 133 & 0.0388 & Downward \\
\hline Calcium, dissolved, $\mathrm{mg} / \mathrm{L}$ & 28,38 & 42.6 & 39.6 & 0.3811 & None \\
\hline Magnesium, dissolved, $\mathrm{mg} / \mathrm{L}$ & 28,38 & 8.6 & 7.9 & 0.7753 & None \\
\hline Residue on evaporation at $105^{\circ} \mathrm{C}$ & 37,38 & 199 & 196 & 0.6601 & None \\
\hline Nitrogen, ammonia plus organic, total as $\mathrm{N}, \mathrm{mg} / \mathrm{L}$ & 37,38 & 1.40 & 1.35 & 0.2068 & None \\
\hline Nitrogen, ammonia, dissolved as $\mathrm{N}, \mathrm{mg} / \mathrm{L}$ & 28,38 & 0.080 & 0.046 & 0.0422 & Downward \\
\hline Nitrogen, nitrite plus nitrate, dissolved as $\mathrm{N}, \mathrm{mg} / \mathrm{L}$ & 28,38 & 0.775 & 0.585 & 0.1650 & None \\
\hline Orthophosphate, dissolved as $\mathrm{P}, \mathrm{mg} / \mathrm{L}$ & 37,38 & 0.082 & 0.0435 & 0.0044 & Downward \\
\hline Phosphorus, total as $\mathrm{P}, \mathrm{mg} / \mathrm{L}$ & 37,38 & 0.36 & 0.35 & 0.4908 & None \\
\hline Carbon, organic, dissolved as $\mathrm{C}, \mathrm{mg} / \mathrm{L}$ & 25,38 & 6.7 & 6.1 & 0.3357 & None \\
\hline Copper, dissolved, $\mu \mathrm{g} / \mathrm{L}$ & 37,38 & 2.1 & 1.8 & 0.0431 & Downward \\
\hline Copper, total recoverable, $\mu \mathrm{g} / \mathrm{L}$ & 28,35 & 12.9 & 10.6 & 0.3125 & None \\
\hline Lead, dissolved, $\mu \mathrm{g} / \mathrm{L}$ & 28,38 & 0.05 & 0.06 & 0.9426 & None \\
\hline Lead, total recoverable, $\mu \mathrm{g} / \mathrm{L}$ & 28,36 & 9.6 & 7.4 & 0.2585 & None \\
\hline Manganese, dissolved, $\mu \mathrm{g} / \mathrm{L}$ & 28,38 & 12.8 & 11.6 & 0.4556 & None \\
\hline Manganese, total recoverable, $\mu \mathrm{g} / \mathrm{L}$ & 28,36 & 285 & 263 & 0.4690 & None \\
\hline Zinc, dissolved, $\mu \mathrm{g} / \mathrm{L}$ & 28,38 & 4.6 & 4.8 & 0.8609 & None \\
\hline Zinc, total recoverable, $\mu \mathrm{g} / \mathrm{L}$ & 28,36 & 45 & 34 & 0.2819 & None \\
\hline
\end{tabular}


Table 9. Mann-Whitney test of differences between distributions of water-quality values and concentrations in stormwater samples collected in 20022005 and $2006-2010$ at all sites. - Continued

[n, number of samples, each time period separated by a comma; shaded values indicate statistical significance for this report with a p-value less than or equal to $0.1000 ; \mathrm{mg} / \mathrm{L}$, milligrams per liter; $\mu \mathrm{g} / \mathrm{L}$, micrograms per liter; ${ }^{\circ} \mathrm{C}$, degrees Celsius; $\mu \mathrm{S} / \mathrm{cm}$, microsiemens per centimeter at $25^{\circ} \mathrm{C} ; \mathrm{CaCO}_{3}$, calcium carbonate; cm, centimeter; N, nitrogen; P, phosphorus; C, carbon; MPN, most probable number]

\begin{tabular}{|c|c|c|c|c|c|}
\hline \multirow[b]{2}{*}{ Property or constituent } & \multicolumn{5}{|c|}{ South Platte River at Denver } \\
\hline & $\mathbf{n}$ & $\begin{array}{l}\text { Median value or } \\
\text { concentration } \\
2002-2005\end{array}$ & $\begin{array}{l}\text { Median value or } \\
\text { concentration } \\
2006-2010\end{array}$ & $\begin{array}{l}\text { Mann-Whitney rank } \\
\text { sum p-value }\end{array}$ & Trend \\
\hline Streamflow, mean, in $\mathrm{ft}^{3} / \mathrm{s}$ & 46,49 & 636 & 1,080 & 0.0010 & Upward \\
\hline $\mathrm{pH}$, lab & 46,48 & 7.5 & 7.5 & 0.0284 & Upward \\
\hline Specific conductance, field, $\mu \mathrm{S} / \mathrm{cm}$ at $25^{\circ} \mathrm{C}$ & 41,46 & 509 & 491 & 0.2956 & None \\
\hline Hardness, as $\mathrm{CaCO}_{3}$, in $\mathrm{mg} / \mathrm{L}$ & 45,48 & 154 & 138 & 0.1222 & None \\
\hline Calcium, dissolved, mg/L & 35,48 & 42.9 & 41.6 & 0.8537 & None \\
\hline Magnesium, dissolved, mg/L & 35,48 & 8.22 & 8.03 & 0.7329 & None \\
\hline Residue on evaporation at $105^{\circ} \mathrm{C}$ & 45,47 & 186 & 186 & 0.7281 & None \\
\hline Nitrogen, ammonia plus organic, total as $\mathrm{N}, \mathrm{mg} / \mathrm{L}$ & 45,47 & 2.1 & 1.5 & 0.0059 & Downward \\
\hline Nitrogen, ammonia, dissolved as $\mathrm{N}, \mathrm{mg} / \mathrm{L}$ & 35,47 & 0.220 & 0.074 & $<0.0001$ & Downward \\
\hline Nitrogen, nitrite plus nitrate, dissolved as $\mathrm{N}, \mathrm{mg} / \mathrm{L}$ & 35,46 & 2.00 & 0.98 & $<0.0001$ & Downward \\
\hline Orthophosphate, dissolved as $\mathrm{P}, \mathrm{mg} / \mathrm{L}$ & 45,47 & 0.238 & 0.122 & $<0.0001$ & Downward \\
\hline Phosphorus, total as $\mathrm{P}, \mathrm{mg} / \mathrm{L}$ & 45,47 & 0.67 & 0.47 & 0.0068 & Downward \\
\hline Carbon, organic, dissolved as $\mathrm{C}, \mathrm{mg} / \mathrm{L}$ & 31,48 & 7.8 & 5.8 & 0.0006 & Downward \\
\hline Copper, dissolved, $\mu \mathrm{g} / \mathrm{L}$ & 45,48 & 3.0 & 2.5 & 0.3597 & None \\
\hline Copper, total recoverable, $\mu \mathrm{g} / \mathrm{L}$ & 35,45 & 18.0 & 15.4 & 0.1063 & None \\
\hline Lead, dissolved, $\mu \mathrm{g} / \mathrm{L}$ & 35,48 & 0.14 & 0.10 & 0.0036 & Downward \\
\hline Lead, total recoverable, $\mu \mathrm{g} / \mathrm{L}$ & 35,45 & 15.4 & 13.1 & 0.1888 & None \\
\hline Manganese, dissolved, $\mu \mathrm{g} / \mathrm{L}$ & 35,48 & 16.4 & 3.25 & $<0.0001$ & Downward \\
\hline Manganese, total recoverable, $\mu \mathrm{g} / \mathrm{L}$ & 35,45 & 285 & 288 & 0.9961 & None \\
\hline Zinc, dissolved, $\mu \mathrm{g} / \mathrm{L}$ & 35,48 & 10.1 & 6.75 & 0.0147 & Downward \\
\hline Zinc, total recoverable, $\mu \mathrm{g} / \mathrm{L}$ & 35,45 & 84 & 60 & 0.0896 & Downward \\
\hline
\end{tabular}


Table 9. Mann-Whitney test of differences between distributions of water-quality values and concentrations in stormwater samples collected in 20022005 and $2006-2010$ at all sites. - Continued

[n, number of samples, each time period separated by a comma; shaded values indicate statistical significance for this report with a p-value less than or equal to $0.1000 ; \mathrm{mg} / \mathrm{L}$, milligrams per liter; $\mu \mathrm{g} / \mathrm{L}$, micrograms per liter; ${ }^{\circ} \mathrm{C}$, degrees Celsius; $\mu \mathrm{S} / \mathrm{cm}$, microsiemens per centimeter at $25^{\circ} \mathrm{C} ; \mathrm{CaCO}_{3}$, calcium carbonate; cm, centimeter; N, nitrogen; P, phosphorus; C, carbon; MPN, most probable number]

\begin{tabular}{|c|c|c|c|c|c|}
\hline \multirow[b]{2}{*}{ Property or constituent } & \multicolumn{5}{|c|}{ Toll Gate Creek above $6^{\text {th }}$ Avenue } \\
\hline & $\mathbf{n}$ & $\begin{array}{l}\text { Median value or } \\
\text { concentration } \\
2002-2005\end{array}$ & $\begin{array}{l}\text { Median value or } \\
\text { concentration } \\
2006-2010\end{array}$ & $\begin{array}{l}\text { Mann-Whitney rank } \\
\text { sum p-value }\end{array}$ & Trend \\
\hline Streamflow, mean, in $\mathrm{ft}^{3} / \mathrm{s}$ & 20,30 & 47 & 182 & 0.0020 & Upward \\
\hline $\mathrm{pH}, \mathrm{lab}$ & 24,33 & 7.3 & 7.6 & $<0.0001$ & Upward \\
\hline Specific conductance, field, $\mu \mathrm{S} / \mathrm{cm}$ at $25^{\circ} \mathrm{C}$ & 21,31 & 690 & 957 & 0.0188 & Upward \\
\hline Hardness, as $\mathrm{CaCO}_{3}$, in $\mathrm{mg} / \mathrm{L}$ & 24,33 & 250 & 251 & 0.2934 & None \\
\hline Calcium, dissolved, mg/L & 21,33 & 67.4 & 76.7 & 0.2142 & None \\
\hline Magnesium, dissolved, mg/L & 21,33 & 12.4 & 14.6 & 0.1315 & None \\
\hline Residue on evaporation at $105^{\circ} \mathrm{C}$ & 22,31 & 246 & 97 & 0.0109 & Downward \\
\hline Nitrogen, ammonia plus organic, total as $\mathrm{N}, \mathrm{mg} / \mathrm{L}$ & 24,32 & 2.25 & 1.40 & 0.0142 & Downward \\
\hline Nitrogen, ammonia, dissolved as $\mathrm{N}, \mathrm{mg} / \mathrm{L}$ & 21,32 & 0.190 & 0.088 & 0.0194 & Downward \\
\hline Nitrogen, nitrite plus nitrate, dissolved as $\mathrm{N}, \mathrm{mg} / \mathrm{L}$ & 21,32 & 0.46 & 0.58 & 0.0373 & Upward \\
\hline Orthophosphate, dissolved as $\mathrm{P}, \mathrm{mg} / \mathrm{L}$ & 32,32 & 0.032 & 0.013 & 0.0405 & Downward \\
\hline Phosphorus, total as $\mathrm{P}, \mathrm{mg} / \mathrm{L}$ & 24,32 & 0.54 & 0.22 & 0.0016 & Downward \\
\hline Carbon, organic, dissolved as $\mathrm{C}, \mathrm{mg} / \mathrm{L}$ & 21,33 & 8.4 & 10.4 & 0.4887 & None \\
\hline Copper, dissolved, $\mu \mathrm{g} / \mathrm{L}$ & 24,33 & 2.8 & 2.2 & 0.1038 & None \\
\hline Copper, total recoverable, $\mu \mathrm{g} / \mathrm{L}$ & 21,33 & 16.6 & 8.3 & 0.0051 & Downward \\
\hline Lead, dissolved, $\mu \mathrm{g} / \mathrm{L}$ & 21,33 & 0.08 & 0.08 & 0.5930 & None \\
\hline Lead, total recoverable, $\mu \mathrm{g} / \mathrm{L}$ & 21,33 & 9.17 & 3.45 & 0.0101 & Downward \\
\hline Manganese, dissolved, $\mu \mathrm{g} / \mathrm{L}$ & 21,33 & 41.8 & 50.9 & 0.6573 & None \\
\hline Manganese, total recoverable, $\mu \mathrm{g} / \mathrm{L}$ & 21,33 & 683 & 244 & 0.0042 & Downward \\
\hline Zinc, dissolved, $\mu \mathrm{g} / \mathrm{L}$ & 21,33 & 7.4 & 8.0 & 0.7494 & None \\
\hline Zinc, total recoverable, $\mu \mathrm{g} / \mathrm{L}$ & 21,33 & 94 & 32 & 0.0010 & Downward \\
\hline
\end{tabular}


Table 9. Mann-Whitney test of differences between distributions of water-quality values and concentrations in stormwater samples collected in 20022005 and 2006-2010 at all sites. - Continued

[n, number of samples, each time period separated by a comma; shaded values indicate statistical significance for this report with a p-value less than or equal to $0.1000 ; \mathrm{mg} / \mathrm{L}$, milligrams per liter; $\mu \mathrm{g} / \mathrm{L}$, micrograms per liter; ${ }^{\circ} \mathrm{C}$, degrees Celsius; $\mu \mathrm{S} / \mathrm{cm}$, microsiemens per centimeter at $25^{\circ} \mathrm{C} ; \mathrm{CaCO}_{3}$, calcium carbonate; cm, centimeter; N, nitrogen; P, phosphorus; C, carbon; MPN, most probable number]

\begin{tabular}{|c|c|c|c|c|c|}
\hline \multirow[b]{2}{*}{ Property or constituent } & \multicolumn{5}{|c|}{ Sand Creek at Mouth near Commerce City } \\
\hline & $\mathbf{n}$ & $\begin{array}{l}\text { Median value or } \\
\text { concentration } \\
2002-2005\end{array}$ & $\begin{array}{l}\text { Median value or } \\
\text { concentration } \\
2006-2010\end{array}$ & $\begin{array}{l}\text { Mann-Whitney rank } \\
\text { sum p-value }\end{array}$ & Trend \\
\hline Streamflow, mean, in $\mathrm{ft}^{3} / \mathrm{s}$ & 34,47 & 102 & 229 & 0.0145 & Upward \\
\hline $\mathrm{pH}$, lab & 34,47 & 7.4 & 7.6 & 0.0018 & Upward \\
\hline Specific conductance, field, $\mu \mathrm{S} / \mathrm{cm}$ at $25^{\circ} \mathrm{C}$ & 30,45 & 765 & 684 & 0.1781 & None \\
\hline Hardness, as $\mathrm{CaCO}_{3}$, in $\mathrm{mg} / \mathrm{L}$ & 33,47 & 234 & 171 & 0.0106 & Downward \\
\hline Calcium, dissolved, $\mathrm{mg} / \mathrm{L}$ & 25,47 & 68.6 & 52.5 & 0.0790 & Downward \\
\hline Magnesium, dissolved, mg/L & 25,47 & 14.0 & 10.1 & 0.1051 & None \\
\hline Residue on evaporation at $105^{\circ} \mathrm{C}$ & 34,47 & 347 & 236 & 0.4999 & None \\
\hline Nitrogen, ammonia plus organic, total as $\mathrm{N}, \mathrm{mg} / \mathrm{L}$ & 33,45 & 2.90 & 2.00 & 0.0579 & Downward \\
\hline Nitrogen, ammonia, dissolved as $\mathrm{N}, \mathrm{mg} / \mathrm{L}$ & 25,45 & 0.28 & 0.09 & 0.0003 & Downward \\
\hline Nitrogen, nitrite plus nitrate, dissolved as $\mathrm{N}, \mathrm{mg} / \mathrm{L}$ & 25,45 & 0.87 & 0.78 & 0.1096 & None \\
\hline Orthophosphate, dissolved as $\mathrm{P}, \mathrm{mg} / \mathrm{L}$ & 33,45 & 0.152 & 0.089 & 0.0023 & Downward \\
\hline Phosphorus, total as $\mathrm{P}, \mathrm{mg} / \mathrm{L}$ & 33,45 & 0.83 & 0.63 & 0.5141 & None \\
\hline Carbon, organic, dissolved as $\mathrm{C}, \mathrm{mg} / \mathrm{L}$ & 24,46 & 12.9 & 9.3 & 0.1132 & None \\
\hline Copper, dissolved, $\mu \mathrm{g} / \mathrm{L}$ & 33,47 & 3.0 & 2.4 & 0.1222 & None \\
\hline Copper, total recoverable, $\mu \mathrm{g} / \mathrm{L}$ & 25,47 & 19.2 & 17.0 & 0.4246 & None \\
\hline Lead, dissolved, $\mu \mathrm{g} / \mathrm{L}$ & 25,47 & 0.13 & 0.14 & 0.3970 & None \\
\hline Lead, total recoverable, $\mu \mathrm{g} / \mathrm{L}$ & 25,47 & 19.1 & 14.5 & 0.5385 & None \\
\hline Manganese, dissolved, $\mu \mathrm{g} / \mathrm{L}$ & 25,47 & 35.1 & 10.6 & 0.0482 & Downward \\
\hline Manganese, total recoverable, $\mu \mathrm{g} / \mathrm{L}$ & 25,47 & 602 & 466 & 0.5191 & None \\
\hline Zinc, dissolved, $\mu \mathrm{g} / \mathrm{L}$ & 32,47 & 34.4 & 10.9 & 0.0322 & Downward \\
\hline Zinc, total recoverable, $\mu \mathrm{g} / \mathrm{L}$ & 24,47 & 148 & 75 & 0.2288 & None \\
\hline
\end{tabular}


Table 9. Mann-Whitney test of differences between distributions of water-quality values and concentrations in stormwater samples collected in 20022005 and $2006-2010$ at all sites. - Continued

[n, number of samples, each time period separated by a comma; shaded values indicate statistical significance for this report with a p-value less than or equal to $0.1000 ; \mathrm{mg} / \mathrm{L}$, milligrams per liter; $\mu \mathrm{g} / \mathrm{L}$, micrograms per liter; ${ }^{\circ} \mathrm{C}$, degrees Celsius; $\mu \mathrm{S} / \mathrm{cm}$, microsiemens per centimeter at $25^{\circ} \mathrm{C} ; \mathrm{CaCO}_{3}$, calcium carbonate; cm, centimeter; N, nitrogen; P, phosphorus; C, carbon; MPN, most probable number]

\begin{tabular}{|c|c|c|c|c|c|}
\hline \multirow[b]{2}{*}{ Property or constituent } & \multicolumn{5}{|c|}{ South Platte River at Henderson } \\
\hline & $\mathbf{n}$ & $\begin{array}{l}\text { Median value or } \\
\text { concentration } \\
2002-2005\end{array}$ & $\begin{array}{l}\text { Median value or } \\
\text { concentration } \\
2006-2010\end{array}$ & $\begin{array}{l}\text { Mann-Whitney rank } \\
\text { sum p-value }\end{array}$ & Trend \\
\hline Streamflow, mean, in $\mathrm{ft}^{3} / \mathrm{s}$ & 35,33 & 1,060 & 1,470 & 0.2538 & None \\
\hline $\mathrm{pH}$, lab & 35,34 & 7.4 & 7.4 & 0.6197 & None \\
\hline Specific conductance, field, $\mu \mathrm{S} / \mathrm{cm}$ at $25^{\circ} \mathrm{C}$ & 30,34 & 655 & 528 & 0.0102 & Downward \\
\hline Hardness, as $\mathrm{CaCO}_{3}$, in $\mathrm{mg} / \mathrm{L}$ & 34,34 & 172 & 134 & 0.0009 & Downward \\
\hline Calcium, dissolved, $\mathrm{mg} / \mathrm{L}$ & 23,34 & 44 & 41 & 0.1796 & None \\
\hline Magnesium, dissolved, mg/L & 23,34 & 10.1 & 8.28 & 0.0735 & Downward \\
\hline Residue on evaporation at $105^{\circ} \mathrm{C}$ & 34,32 & 264 & 142 & 0.0033 & Downward \\
\hline Nitrogen, ammonia plus organic, total as $\mathrm{N}, \mathrm{mg} / \mathrm{L}$ & 34,33 & 4.95 & 2.60 & $<0.0001$ & Downward \\
\hline Nitrogen, ammonia, dissolved as $\mathrm{N}, \mathrm{mg} / \mathrm{L}$ & 23,33 & 1.48 & 0.578 & 0.0003 & Downward \\
\hline Nitrogen, nitrite plus nitrate, dissolved as $\mathrm{N}, \mathrm{mg} / \mathrm{L}$ & 23,33 & 2.57 & 1.87 & 0.0066 & Downward \\
\hline Orthophosphate, dissolved as $\mathrm{P}, \mathrm{mg} / \mathrm{L}$ & 34,33 & 0.598 & 0.367 & 0.0094 & Downward \\
\hline Phosphorus, total as $\mathrm{P}, \mathrm{mg} / \mathrm{L}$ & 34,33 & 1.585 & 0.96 & $<0.0001$ & Downward \\
\hline Carbon, organic, dissolved as $\mathrm{C}, \mathrm{mg} / \mathrm{L}$ & 19,34 & 10.6 & 7.5 & 0.1669 & None \\
\hline Copper, dissolved, $\mu \mathrm{g} / \mathrm{L}$ & 34,34 & 3.0 & 2.8 & 0.6673 & None \\
\hline Copper, total recoverable, $\mu \mathrm{g} / \mathrm{L}$ & 23,32 & 31.9 & 22.4 & 0.0238 & Downward \\
\hline Lead, dissolved, $\mu \mathrm{g} / \mathrm{L}$ & 23,34 & 0.26 & 0.21 & 0.0478 & Downward \\
\hline Lead, total recoverable, $\mu \mathrm{g} / \mathrm{L}$ & 23,32 & 33.2 & 17.3 & 0.0212 & Downward \\
\hline Manganese, dissolved, $\mu \mathrm{g} / \mathrm{L}$ & 23,34 & 85.8 & 33.1 & 0.0060 & Downward \\
\hline Manganese, total recoverable, $\mu \mathrm{g} / \mathrm{L}$ & 23,32 & 542 & 360 & 0.0217 & Downward \\
\hline Zinc, dissolved, $\mu \mathrm{g} / \mathrm{L}$ & 23,34 & 17.0 & 17.3 & 0.7634 & None \\
\hline Zinc, total recoverable, $\mu \mathrm{g} / \mathrm{L}$ & 23,32 & 146 & 91 & 0.0732 & Downward \\
\hline
\end{tabular}




\section{Comparison to Previous Results}

For this report, the Mann-Whitney nonparametric rank sum statistical test was used to determine if the distribution of values and concentrations for 2002-2005 samples was different from the distributions of values and concentrations in stormwater determined for 2006-2010 (table 9). Additional corroboration of many of the statistical tests trends are illustrated in the boxplots of figure 4 . A probability value (p-value) less than or equal to 0.10 was used as the criteria to determine if an apparent trend was statistically significant. These results are presented for each of the five stations in table 9.

In an earlier study, Bossong and others (2008) indicated that the general quality of stormwater had improved during 2002-2005 compared to 1998-2001, having fewer exceedances of Colorado standards, and showing downward trends for many water-quality values and concentrations. These trends coincided with general downward or relatively similar mean streamflows for the 2002-2005 compared to 1998-2001, which indicates that dilution may be a smaller influence on values and concentrations than other factors. For this report, downward trends were indicated for many constituents at each station during 2006-2010 compared to 2002-2005 (fig. 4; table 9). The trends for mean streamflow for 2006-2010 compared to 2002-2005 are upward at all sites except for the South Platte River at Henderson, indicating that dilution by larger streamflows could be a factor in the downward concentration trends (fig. 4). At Union, downward trends were indicated for hardness, dissolved ammonia, dissolved orthophosphate, and dissolved copper. Upward trends in properties and constituents at Union were indicated for $\mathrm{pH}$. At Denver, downward trends were indicated for total ammonia plus organic nitrogen, dissolved ammonia, dissolved nitrite plus nitrate, dissolved orthophosphate, total phosphorus, dissolved organic carbon, and dissolved lead, manganese, and zinc, and total recoverable zinc. An upward trend in properties and constituents at Denver was indicated for $\mathrm{pH}$. At Toll Gate, downward trends were indicated for residue on evaporation, total ammonia plus organic nitrogen, dissolved ammonia, dissolved orthophosphate, total phosphorus, and total recoverable copper, lead, manganese, and zinc. Upward trends in properties and constituents at Toll Gate were indicated for $\mathrm{pH}$, specific conductance, and dissolved nitrite plus nitrate. At Sand Creek, downward trends were indicated for hardness, dissolved calcium, total ammonia plus organic nitrogen, dissolved ammonia, orthophosphate,

manganese, and zinc. An upward trend in properties and constituents at Sand Creek was indicated for $\mathrm{pH}$. Downward trends at Henderson were indicated for specific conductance, hardness, dissolved magnesium, dissolved residue on evaporation, total ammonia plus organic nitrogen, dissolved ammonia, dissolved nitrite plus nitrate, dissolved orthophosphate, total phosphorus, dissolved lead and manganese, and total recoverable copper, lead, manganese, and zinc.

In general, the quality of stormwater (2006-2010) has improved for many water-quality constituents, which had lower values and concentrations than those in stormwater collected in 2002-2005. However, the physical basis, processes, and the role of dilution that account for these changes are complex and are beyond the scope of this report.

\section{Summary}

The quality of stormwater runoff is of interest to many management and regulatory agencies as well as scientists, recreational stream users, and the general public. In response to this interest, the U.S. Geological Survey, in cooperation with the Urban Drainage and Flood Control District, systematically collected stormwater samples from a network of five monitoring stations in 
and around metropolitan Denver, Colorado. This report describes the quality of stormwater sampled from October 1, 2006, to December 31, 2010. The network includes three stations: South Platte River below Union Avenue at Englewood, South Platte River at Denver, and South Platte River at Henderson, known as Union, Denver, and Henderson. The stations on the South Platte River receive streamflow from several tributaries, and the South Platte River is sometimes referred to as a "receiving stream." The network also includes stations on two tributary streams: Sand Creek, which is tributary to the South Platte River, and Toll Gate Creek, which is tributary to Sand Creek. Sampling was accomplished by using refrigerated automatic pumping samplers that were used to collect composite stormwater samples. About 200 time-weighted composite stormwater samples were collected by compositing individual aliquots of stormwater that were obtained at fixed-time increments typically during 12-hour intervals; bacteriological samples were collected manually from streams during some storms.

Stormwater samples were analyzed at the U.S. Geological Survey National Water Quality Laboratory during 2006-2010 for water-quality properties $\mathrm{pH}$, specific conductance, hardness, and residue on evaporation at 105 degrees Celsius; for major ions (calcium, magnesium) and organic carbon; for nutrients such as ammonia plus organic nitrogen, ammonia, dissolved nitrite plus nitrate, orthophosphate, and total phosphorus; and for metals, including total recoverable and dissolved phases of copper, lead, manganese, and zinc. Samples analyzed for bacteriological indicators including Escherichia coli and fecal coliform were collected during selected storms and were analyzed at the Metro Wastewater Reclamation Laboratory.

Quality-control samples were collected and the analyses of blank sample results indicated no substantial contribution to concentrations from ambient field conditions or sampling equipment. For the 151 duplicate analyses, the median RPD was 1.9 percent, and RPDs ranged from 0 to 115 percent. For the 151 duplicate analyses, the 90th-percentile RPDs ranged from 0.4 to 45 percent. Among those results dissolved copper, lead, and manganese, accounted for the largest RPDs (90th percentile RPDs ranged from 34 to 45 percent). Excluding these dissolved metals, the range of 90th percentile values in table was 0.4 to 20 percent. The RPD results indicate generally satisfactory reproducibility for the majority water-quality analysis types. For the dissolved phase of the metals copper, lead, and manganese, reproducibility was only fair.

The results from laboratory analyses indicate, in general, and particularly for nutrients, that some values and concentrations for water-quality constituents increase with contributing drainage area in the South Platte River. No well-defined relation was identified between concentration and the amount of urban land cover identified using the U.S. Geological Survey National Land Cover data. For example, the mean concentration for ammonia plus organic nitrogen is $1.4 \mathrm{mg} / \mathrm{L}$ at the South Platte River below Union Avenue station, $1.8 \mathrm{mg} / \mathrm{L}$ at South Platte River at Denver station, and $2.9 \mathrm{mg} / \mathrm{L}$ at South Platte River at Henderson station. This pattern correlates with the size of the local contributing drainage area, which also increases downstream. Sand Creek, a tributary that flows into the South Platte River between the South Platte River at Denver and South Platte River at Henderson stations, has Toll Gate Creek above 6th Avenue at Aurora station as tributary. Some values and concentrations of results also increase in a downstream direction from the Toll Gate above 6th Avenue at Aurora station to the Sand Creek at mouth near Commerce City station. For some water-quality constituents, concentrations measured in the tributary streams (Toll Gate above 6th Avenue at Aurora and Sand Creek at mouth near Commerce City) are higher than concentrations measured in the upstream reach of the South Platte River (South Platte River below Union Avenue). 
A summary of results from 2006-2010 stormwater samples that did not meet (exceeded) CDPHE water-quality standards is presented in this report for individual stations. The results indicate few exceptions to standards except for dissolved manganese and zinc and Eschericia coli. Stormwater collected at South Platte River below Union Avenue had about 10 percent acute or chronic dissolved manganese exceedances in samples; samples collected at South Platte River at Denver had less than 5 percent acute or chronic dissolved manganese exceedances. In contrast, samples collected at Toll Gate above 6th Avenue at Aurora, Sand Creek at mouth near Commerce City, and South Platte River at Henderson, each had about 30 to 50 percent exceedances of both acute and chronic dissolved manganese standards. Of the samples collected at Sand Creek at mouth near Commerce City, 1 sample exceeded the acute standard and 4 samples exceeded the chronic standard for dissolved zinc, but no samples collected from the other sites exceeded either standard for zinc. Almost all samples of stormwater analyzed for Escherichia coli exceeded the Colorado numeric standards. A numerical standard for fecal coliform is no longer applicable as of 2004.

The Mann-Whitney nonparametric rank sum statistical test was used to determine if the distribution of concentrations and values from 2006-2010 was different from the distributions determined for 2002-2005. A probability value (p-value) less than or equal to 0.10 was the criteria used to determine if an apparent trend was statistically significant.

Results from the 2002-2005 study indicated that the general quality of stormwater had improved during 2002-2005 compared to 1998-2001, having fewer exceedances of Colorado standards, and showing downward trends for many water-quality values and concentrations. These trends coincided with general downward or relatively similar mean streamflows for the 2002-2005 compared to 1998-2001, which indicates that dilution may be a smaller influence on values and concentrations than other factors. For this report, downward trends were indicated for many constituents at each station during 2006-2010 compared to 2002-2005. The trends for mean streamflow for 2006-2010 compared to 2002-2005 are upward at all stations except for South Platte River at Henderson, indicating that dilution by larger flows could be a factor in the downward concentration trends. At South Platte River below Union Avenue, downward trends were indicated for hardness, dissolved ammonia, dissolved orthophosphate, and dissolved copper. Upward trends in properties and constituents at South Platte River below Union Avenue were indicated for $\mathrm{pH}$. At South Platte River at Denver, downward trends were indicated for total ammonia plus organic nitrogen, dissolved ammonia, dissolved nitrite plus nitrate, dissolved orthophosphate, total phosphorus, dissolved organic carbon, and dissolved lead, manganese, and zinc, and total recoverable zinc. An upward trend in properties and constituents at South Platte River at Denver was indicated for $\mathrm{pH}$. At Toll Gate above 6th Avenue at Aurora, downward trends were indicated for residue on evaporation, total ammonia plus organic nitrogen, dissolved ammonia, dissolved orthophosphate, total phosphorus, and total recoverable copper, lead, manganese, and zinc. Upward trends properties and constituents at Toll Gate above 6th Avenue at Aurora were indicated for $\mathrm{pH}$, specific conductance, and dissolved nitrite plus nitrate. At Sand Creek at mouth near Commerce City, downward trends were indicated for hardness, dissolved calcium, total ammonia plus organic nitrogen, and dissolved ammonia, orthophosphate, manganese, and zinc. Upward trends for properties and constituents at Sand Creek at mouth near Commerce City was indicated for $\mathrm{pH}$. Downward trends at South Platte River at Henderson were indicated for specific conductance, hardness, dissolved magnesium, residue on evaporation, total ammonia plus organic nitrogen, dissolved ammonia, dissolved nitrite plus nitrate, dissolved orthophosphate, total phosphorus, dissolved lead and manganese, and total recoverable copper, lead, manganese, and zinc. 
In general, the quality of stormwater (2006-2010) has improved for many water-quality constituents, which had lower values and concentrations than those in stormwater collected in 2002-2005. However, the physical basis, processes, and the role of dilution that account for these changes are complex beyond the scope of this report.

\section{References Cited}

Blakely, S.R., Mustard, M.H., and Doerfer, J.T., 1983, Analysis of the August 14, 1980, rainstorm and storm runoff to the South Platte River in the southern Denver metropolitan area, Colorado: U.S. Geological Survey Water-Resources Investigations Report 83-4138, 35 p.

Bossong, C.R., Stevens, M.R., Doerfer, J.T., and Glass, B.R., 2005, Summary and evaluation of the quality of stormwater in Denver, Colorado, water years 1998-2001: U.S. Geological Survey Scientific Investigations Report 2005-5150, 90 p.

Bossong, C.R., and Fleming, A.C., 2008, Summary and evaluation of the quality and stormwater in Denver, Colorado, October 2001 to October 2005: U.S. Geological Survey Scientific Investigations Report 2008-5134, 102 p.

Brenton, R.W., and Arnett, T.L., 1993, Methods of analysis by the U.S. Geological Survey National Water Quality Laboratory-Determination of dissolved organic carbon by uv-promoted persulfate oxidation and infrared spectrometry: U.S. Geological Survey Open-File Report 92-480, $12 \mathrm{p}$.

Childress, C.J.O., Foreman, W.T., Connor, B.F., and Maloney, T.J., 1999, New reporting procedures based on long-term method detection levels and some considerations for interpretations of water-quality data provided by the U.S. Geological Survey National Water Quality Laboratory: U.S. Geological Survey Open-File Report 99-193, 19 p.

Colorado Department of Public Health and Environment, 2011a, Regulation no. 31, The basic standards and methodologies for surface water (5 CCR 1002-31): Colorado Department of Public Health and Environment, Water Quality Control Commission, variously paginated.

Colorado Department of Public Health and Environment, 2011b, Regulation no. 38, Classification and numeric standards for South Platte River basin: Colorado Department of Public Health and Environment, Water Quality Control Commission, variously paginated.

Denver Regional Council of Governments, 1983, Urban runoff quality in the Denver region: Denver, Colo., Denver Regional Council of Governments, 156 p.

Ellis, S.R., 1978, Hydrologic data for urban storm runoff from three localities in the Denver metropolitan area, Colorado: U.S. Geological Survey Open-File Report 78-410, 135 p.

Ellis, S.R., and Alley, W.B., 1979, Hydrologic data for urban storm runoff from three localities in the Denver metropolitan area, Colorado: U.S. Geological Survey Water-Resources Investigations Report 79-64, 60 p.

Ellis, S.R., Doerfer, J.T., Mustard, M.H., Blakely, S.R., and Gibbs, J.W., 1984, Analysis of urban storm-runoff data and the effects on the South Platte River, Denver metropolitan area, Colorado: U.S. Geological Survey Water-Resources Investigations Report 84-4159, 66 p.

Ellis, S.R., and Mustard, M.H., 1985, A summary of urban runoff studies in the Denver metropolitan area, Colorado: U.S. Geological Water-Resources Investigations Report 84-4072, $31 \mathrm{p}$.

Faires, L.M., 1993, Methods of analysis by the U.S. Geological Survey National Water Quality Laboratory-Determination of metals in water by inductively coupled plasma-mass spectrometry: U.S. Geological Survey Open-File Report 92-634, 28 p. 
Fishman, M.J., ed., 1993, Methods of analysis by the U.S. Geological Survey National Water Quality Laboratory-Determination of inorganic and organic constituents in water and fluvial sediments: U.S. Geological Survey Open-File Report 93-125, 217 p.

Fishman, M.J., and Friedman, L.C., 1989, Methods for determination of inorganic substances in water and fluvial sediments: U.S. Geological Survey Techniques of Water-Resources Investigations, book 5, chap. A1, $545 \mathrm{p}$.

Garbarino, J.R., and Struzeski, T.M., 1998, Methods of analysis by the U.S. Geological Survey National Water Quality Laboratory-Determination of elements in whole-water digests using inductively coupled plasma-optical emission spectrometry and inductively coupled plasma-mass spectrometry: U.S. Geological Survey Open-File Report 98-165, 101 p.

Gibbs, J.W., 1981, Hydrologic data for urban storm runoff from nine sites in the Denver metropolitan area, Colorado: U.S. Geological Survey Open-File Report 81-682, 142 p.

Gibbs, J.W., Arnold, L.M., and Reed, R.L., 1983, Hydrologic data for the drainage basins of Chatfield and Cherry Creek Lakes, Denver metropolitan area: U.S. Geological Survey Open-File Report 83-857, 244 p.

Gibbs, J.W., and Doerfer, J.T., 1982, Hydrologic data for urban storm runoff in the Denver metropolitan area, Colorado: U.S. Geological Survey Open-File Report 82-872, 553 p.

Hall, D.C., and Duncan, A.C., 1980, Hydrologic data from Upper Grange Hall Creek Basin, Northglenn, Adams County, Colorado: U.S. Geological Survey Open-File Report 80-578, 132 p.

Hall, D.C., and Duncan, A.C., 1981, Characterization of urban runoff from Grange Hall Creek at Northglenn, Adams County, Colorado: U.S. Geological Survey Water-Resources Investigations Report 81-28, 50 p.

Helsel, D.R., 2005, Nondetects and data analysis - statistics for censored environmental data: New York, John Wiley and Sons, $250 \mathrm{p}$.

Helsel, D.R., and Hirsch, R.M., 1992, Statistical methods in water resources-Studies in environmental science 49: New York, Elsevier, 529 p.

Hem, J.D., 1985, Study and interpretation of the chemical characteristics of natural water (3d ed.): U.S. Geological Survey Water-Supply Paper 2254, 264 p.

Hoffman, G.L., Fishman, M.J., and Garbarino, J.R., 1996, Methods of analysis by the U.S. Geological Survey National Water Quality Laboratory-In-bottle acid digestion of whole-water samples: U.S. Geological Survey Open-File Report 96-225, 28 p.

Iman, R.L., and Conover, W.J., 1983, A modern approach to statistics: New York, John Wiley and Sons, $497 \mathrm{p}$.

Mustard, M.H., Ellis, S.R., and Gibbs, J.W., 1985, Runoff and washoff loads from rainfallsimulation experiments on a street surface and a native pasture in the Denver metropolitan area, Colorado: U.S. Geological Survey Open-File Report 84-820, 44 p.

Patton, C.J., and Truitt, E.P., 1992, Methods of analysis by the U.S. Geological Survey National Water Quality Laboratory-Determination of total phosphorus by a Kjeldahl digestion method and an automated colorimetric finish that includes dialysis: U.S. Geological Survey Open-File Report 92-146, 39 p.

Patton, C.J., and Truitt, E.P., 2000, Methods of analysis by the U.S. Geological Survey National Water Quality Laboratory-Determination of ammonium plus organic nitrogen by a Kjeldahl digestion method and an automated photometric finish that includes digest cleanup by gas diffusion: U.S. Geological Survey Open-File Report 2000-170, 31 p. 
Rantz, S.E., and others, 1982, Measurement and computa-tion of streamflow-Volume 1, Measurement of stage and discharge, and Volume 2, Computation of discharge: U.S. Geological Survey Water-Supply Paper 2175, 630 p.

Turnipseed, D. P., and Sauer, V.B., 2010, Discharge measurements at gaging stations: U.S. Geological Survey Techniques and Methods 3-A8, xiv, 87 p.

Sauer, V.B., and Turnipseed, D. P., 2010, Stage measurement at gaging stations: U.S. Geological Survey Techniques and Methods 3-A7, x, 45 p.

Urban Drainage and Flood Control District, 2012, ALERT system real-time flood detection and current weather conditions: Urban Drainage and Flood Control District Web site accessed March 2012 at http://alert.udfcd.org/.

U.S. Geological Survey, variously dated, National field manual for the collection of water-quality data: U.S. Geological Survey Techniques of Water-Resources Investigations, book 9, chaps. A1-A9 (also available online at http://water.usgs.gov/pubs/twri9A/).

U.S. Geological Survey, 2006-2010, Water resources data for Colorado, water years 2006-2010: U.S. Geological Survey Water-Data Reports CO-06-1 to CO-10-1 (published annually).

U.S. Geological Survey, 2003, National land cover data, 1992: Accessed February 1, 2012, at http://eros.usgs.gov/\#/Find_Data/Products_and_Data_Available/Land_Cover_Products 
Appendix 
Table A1. Statistics for concentrations and measurement values at South Platte River below Union Avenue at Englewood, $2006-2010$.

$\left[\mu \mathrm{S} / \mathrm{cm}\right.$ at $25^{\circ} \mathrm{C}$, microsiemens per centimeter at 25 degrees Celsius; $\mathrm{mL}$, milliliter; $\mathrm{CaCO}_{3}$, calcium carbonate; mg/L, milligrams per liter; $\mu \mathrm{g} / \mathrm{L}$, micrograms per liter; mm, millimeter; N, nitrogen; $\mathrm{P}$, phosphorus; $\mathrm{C}$, carbon; SD, standard deviation; $\mathrm{n}$, number of samples; nlt, number of "less thans" or censored data; \%, percentile; MPN, most probable number; --, not computed; multiple censoring level statistics uses log-probability regression on values greater than the censoring level to predict statistics that are affected by the censoring level (mean, standard deviation, and 25th percentile; conventional univariate statistics are used when no censored values are used; multiple detection limit techniques are used when censored values are part of the data for a particular value or concentration]

\begin{tabular}{|c|c|c|c|c|c|c|c|c|c|}
\hline \multirow[b]{3}{*}{ Property or constituent } & \multicolumn{9}{|c|}{06710247 South Platte River below Union Avenue near Englewood, Colorado, 2006} \\
\hline & \multicolumn{5}{|c|}{ Multiple censoring level statistics } & \multirow[b]{2}{*}{ n } & \multirow[b]{2}{*}{ nlt } & \multicolumn{2}{|c|}{$\begin{array}{l}\text { Range of uncensored } \\
\text { values }\end{array}$} \\
\hline & Mean & SD & $25 \%$ & $\begin{array}{l}\text { Median } \\
50 \%\end{array}$ & $75 \%$ & & & Minimum & Maximum \\
\hline $\mathrm{pH}$, standard units & 7.8 & 0.2 & 7.6 & 7.8 & 7.8 & 10 & 0 & 7.6 & 8.4 \\
\hline Specific conductance, $\mu \mathrm{S} / \mathrm{cm}$ at $25^{\circ} \mathrm{C}$ & 531 & 214 & 373 & 429 & 645 & 10 & 0 & 356 & 993 \\
\hline Hardness, total, $\mathrm{mg} / \mathrm{L}$ as $\mathrm{CaCO}_{3}$ & 159 & 42 & 124 & 141 & 186 & 10 & 0 & 121 & 247 \\
\hline Magnesium, mg/L & 9.71 & 3.32 & 7.11 & 7.94 & 11.6 & 10 & 0 & 6.84 & 16.1 \\
\hline Suspended solids, residue on evaporation at 105 & & & & & & & & & \\
\hline degrees Celsius, $\mathrm{mg} / \mathrm{L}$ & 199 & 190 & 60 & 178 & 296 & 10 & 0 & 16 & 645 \\
\hline Nitrogen, total, ammonia plus organic as $\mathrm{N}, \mathrm{mg} / \mathrm{L}$ & 1.38 & 1.02 & 0.73 & 1.10 & 1.40 & 10 & 0 & 0.50 & 4.00 \\
\hline Nitrogen, dissolved, ammonia as $\mathrm{N}, \mathrm{mg} / \mathrm{L}$ & 0.073 & 0.042 & 0.042 & 0.056 & 0.12 & 10 & 0 & 0.013 & 0.138 \\
\hline Nitrogen, dissolved, nitrite plus nitrate as $\mathrm{N}, \mathrm{mg} / \mathrm{L}$ & 0.758 & 0.507 & 0.39 & 0.6 & 0.94 & 10 & 0 & 0.17 & 1.71 \\
\hline Orthophosphate, dissolved as $\mathrm{P}, \mathrm{mg} / \mathrm{L}$ & 0.054 & 0.029 & 0.031 & 0.053 & 0.065 & 10 & 0 & 0.024 & 0.123 \\
\hline Phosphorus, total as $\mathrm{P}, \mathrm{mg} / \mathrm{L}$ & 0.326 & 0.246 & 0.140 & 0.300 & 0.400 & 10 & 0 & 0.080 & 0.930 \\
\hline Escherichia Coli, MPN/100 mL & -- & -- & -- & -- & -- & 1 & 0 & 9,400 & -- \\
\hline Fecal coliform, MPN/100 mL & -- & -- & -- & -- & -- & 1 & 0 & 12,000 & -- \\
\hline Copper, dissolved, $\mu \mathrm{g} / \mathrm{L}$ & 2.06 & 0.57 & 1.70 & 2.30 & 2.50 & 0 & 0 & 1.10 & 2.80 \\
\hline Copper, total recoverable, $\mu \mathrm{g} / \mathrm{L}$ & 10.8 & 8.9 & 4.6 & 9.7 & 12.9 & 10 & 0 & 3.3 & 33.5 \\
\hline Lead, dissolved, $\mu \mathrm{g} / \mathrm{L}$ & 0.06 & 0.02 & 0.04 & 0.06 & 0.07 & 10 & 2 & 0.04 & 0.10 \\
\hline Lead, total recoverable, $\mu \mathrm{g} / \mathrm{L}$ & 7.0 & 7.2 & 2.2 & 6.2 & 8.1 & 10 & 0 & 1.0 & 25.7 \\
\hline Manganese, dissolved, $\mu \mathrm{g} / \mathrm{L}$ & 21.7 & 25.0 & 6.4 & 11.0 & 29.8 & 10 & 0 & 2.6 & 81.2 \\
\hline Manganese, total recoverable, $\mu \mathrm{g} / \mathrm{L}$ & 286 & 204 & 183 & 257 & 307 & 10 & 0 & 42.2 & 806 \\
\hline Zinc, dissolved, $\mu \mathrm{g} / \mathrm{L}$ & 5.6 & 2.0 & 4.3 & 5.9 & 7.3 & 10 & 0 & 1.9 & 8.2 \\
\hline Zinc, total recoverable, $\mu \mathrm{g} / \mathrm{L}$ & 37 & 37 & 11 & 30 & 42 & 10 & 0 & 7 & 134 \\
\hline
\end{tabular}


Table A1. Statistics for concentrations and measurement values at South Platte River below Union Avenue at Englewood, 2006-2010.-Continued

$\left[\mu \mathrm{S} / \mathrm{cm}\right.$ at $25^{\circ} \mathrm{C}$, microsiemens per centimeter at 25 degrees Celsius; $\mathrm{mL}$, milliliter; $\mathrm{CaCO}_{3}$, calcium carbonate; $\mathrm{mg} / \mathrm{L}$, milligrams per liter; $\mu \mathrm{g} / \mathrm{L}$, micrograms per liter; mm, millimeter; N, nitrogen; $\mathrm{P}$, phosphorus; $\mathrm{C}$, carbon; SD, standard deviation; $\mathrm{n}$, number of samples; nlt, number of "less thans" or censored data; \%, percentile; MPN, most probable number; --, not computed; multiple censoring level statistics uses log-probability regression on values greater than the censoring level to predict statistics that are affected by the censoring level (mean, standard deviation, and 25th percentile; conventional univariate statistics are used when no censored values are used; multiple detection limit techniques are used when censored values are part of the data for a particular value or concentration]

\begin{tabular}{|c|c|c|c|c|c|c|c|c|c|}
\hline \multirow[b]{2}{*}{ Property or constituent } & \multicolumn{5}{|c|}{ Multiple censoring level statistics } & \multirow[b]{2}{*}{$\mathrm{n}$} & \multirow[b]{2}{*}{ nlt } & \multicolumn{2}{|c|}{$\begin{array}{c}\text { Range of uncensored } \\
\text { values }\end{array}$} \\
\hline & Mean & SD & $25 \%$ & $\begin{array}{c}\text { Median } \\
50 \% \\
\end{array}$ & $75 \%$ & & & Minimum & Maximum \\
\hline $\mathrm{pH}$, standard units & 7.8 & 0.1 & 7.8 & 7.8 & 7.9 & 6 & 0 & 7.6 & 7.9 \\
\hline Specific conductance, $\mu \mathrm{S} / \mathrm{cm}$ at $25^{\circ} \mathrm{C}$ & 335 & 103 & 288 & 301 & 311 & 6 & 0 & 268 & 545 \\
\hline Hardness, total, $\mathrm{mg} / \mathrm{L}$ as $\mathrm{CaCO}_{3}$ & 103 & 27 & 89 & 93 & 106 & 6 & 0 & 82 & 156 \\
\hline Calcium, mg/L & 30.2 & 7.3 & 25.7 & 27.6 & 32.2 & 6 & 0 & 24.3 & 44.3 \\
\hline Magnesium, mg/L & 6.65 & 2.21 & 5.60 & 6.00 & 6.18 & 6 & 0 & 5.06 & 11.1 \\
\hline $\begin{array}{l}\text { Suspended solids, residue on evaporation at } 105 \\
\text { degrees Celsius, } \mathrm{mg} / \mathrm{L}\end{array}$ & 196 & 190 & 58 & 118 & 330 & 6 & 0 & 34 & 520 \\
\hline Nitrogen, total, ammonia plus organic as $\mathrm{N}, \mathrm{mg} / \mathrm{L}$ & 1.3 & 0.7 & 0.67 & 1.25 & 2 & 6 & 0 & 0.46 & 2.20 \\
\hline Nitrogen, dissolved, ammonia as $\mathrm{N}, \mathrm{mg} / \mathrm{L}$ & 0.065 & 0.027 & 0.039 & 0.067 & 0.076 & 6 & 1 & 0.039 & 0.108 \\
\hline Nitrogen, dissolved, nitrite plus nitrate as $\mathrm{N}, \mathrm{mg} / \mathrm{L}$ & 0.521 & 0.215 & 0.38 & 0.46 & 0.58 & 6 & 0 & 0.33 & 0.92 \\
\hline Orthophosphate, dissolved as $\mathrm{P}, \mathrm{mg} / \mathrm{L}$ & 0.059 & 0.045 & 0.017 & 0.050 & 0.113 & 6 & 0 & 0.010 & 0.114 \\
\hline Phosphorus, total as $\mathrm{P}, \mathrm{mg} / \mathrm{L}$ & 0.428 & 0.318 & 0.130 & 0.395 & 0.740 & 6 & 0 & 0.070 & 0.840 \\
\hline Carbon, dissolved, organic as $\mathrm{C}, \mathrm{mg} / \mathrm{L}$ & 9.0 & 5.3 & 5.7 & 6.5 & 11.7 & 6 & 0 & 4.9 & 18.6 \\
\hline Escherichia Coli, MPN/100 mL & -- & -- & -- & -- & -- & 1 & 0 & 1,100 & -- \\
\hline Fecal coliform, MPN/100 mL & -- & -- & -- & -- & -- & 1 & 0 & 1,700 & -- \\
\hline Copper, dissolved, $\mu \mathrm{g} / \mathrm{L}$ & 2.15 & 1.21 & 1.60 & 1.75 & 1.80 & 6 & 0 & 1.40 & 4.60 \\
\hline Copper, total recoverable, $\mu \mathrm{g} / \mathrm{L}$ & 13.1 & 9.7 & 5.1 & 10.5 & 23.7 & 6 & 0 & 2.9 & 25.8 \\
\hline Lead, dissolved, $\mu \mathrm{g} / \mathrm{L}$ & 0.072 & 0.095 & 0.014 & 0.043 & 0.07 & 6 & 3 & 0.06 & 0.26 \\
\hline Lead, total recoverable, $\mu \mathrm{g} / \mathrm{L}$ & 11.2 & 9.3 & 4.0 & 8.3 & 22.4 & 6 & 0 & 1.6 & 22.7 \\
\hline Manganese, dissolved, $\mu \mathrm{g} / \mathrm{L}$ & 25.9 & 35.6 & 11.0 & 11.7 & 18.1 & 6 & 0 & 4.8 & 98.0 \\
\hline Manganese, total recoverable, $\mu \mathrm{g} / \mathrm{L}$ & 301 & 199 & 89 & 298 & 522 & 6 & 0 & 72 & 529 \\
\hline Zinc, dissolved, $\mu \mathrm{g} / \mathrm{L}$ & 4.0 & 1.9 & 2.8 & 3.5 & 3.8 & 6 & 0 & 2.8 & 7.8 \\
\hline Zinc, total recoverable, $\mu \mathrm{g} / \mathrm{L}$ & 44 & 31 & 21 & 34 & 79 & 6 & 0 & 13 & 87 \\
\hline
\end{tabular}


Table A1. Statistics for concentrations and measurement values at South Platte River below Union Avenue at Englewood, 2006-2010.-Continued

$\left[\mu \mathrm{S} / \mathrm{cm}\right.$ at $25^{\circ} \mathrm{C}$, microsiemens per centimeter at 25 degrees Celsius; $\mathrm{mL}$, milliliter; $\mathrm{CaCO}_{3}$, calcium carbonate; $\mathrm{mg} / \mathrm{L}$, milligrams per liter; $\mu \mathrm{g} / \mathrm{L}$, micrograms per liter; mm, millimeter; $\mathrm{N}$, nitrogen; $\mathrm{P}$, phosphorus; $\mathrm{C}$, carbon; SD, standard deviation; $\mathrm{n}$, number of samples; nlt, number of "less thans" or censored data; \%, percentile; MPN, most probable number; --, not computed; multiple censoring level statistics uses log-probability regression on values greater than the censoring level to predict statistics that are affected by the censoring level (mean, standard deviation, and 25th percentile; conventional univariate statistics are used when no censored values are used; multiple detection limit techniques are used when censored values are part of the data for a particular value or concentration]

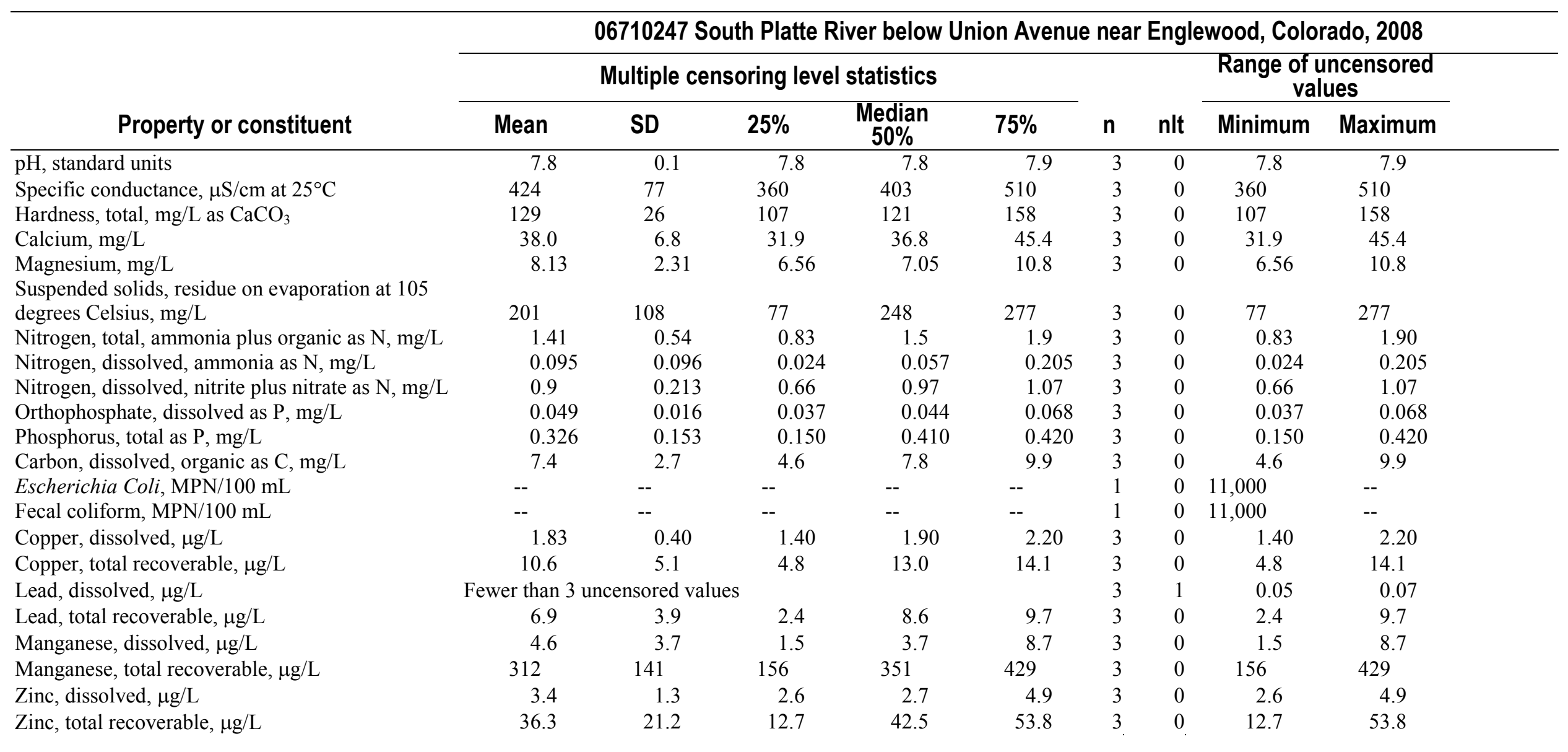


Table A1. Statistics for concentrations and measurement values at South Platte River below Union Avenue at Englewood, 2006-2010.-Continued

$\left[\mu \mathrm{S} / \mathrm{cm}\right.$ at $25^{\circ} \mathrm{C}$, microsiemens per centimeter at 25 degrees Celsius; $\mathrm{mL}$, milliliter; $\mathrm{CaCO}_{3}$, calcium carbonate; $\mathrm{mg} / \mathrm{L}$, milligrams per liter; $\mu \mathrm{g} / \mathrm{L}$, micrograms per liter; mm, millimeter; N, nitrogen; P, phosphorus; C, carbon; SD, standard deviation; n, number of samples; nlt, number of "less thans" or censored data; \%, percentile; MPN, most probable number; --, not computed; multiple censoring level statistics uses log-probability regression on values greater than the censoring level to predict statistics that are affected by the censoring level (mean, standard deviation, and 25th percentile; conventional univariate statistics are used when no censored values are used; multiple detection limit techniques are used when censored values are part of the data for a particular value or concentration]

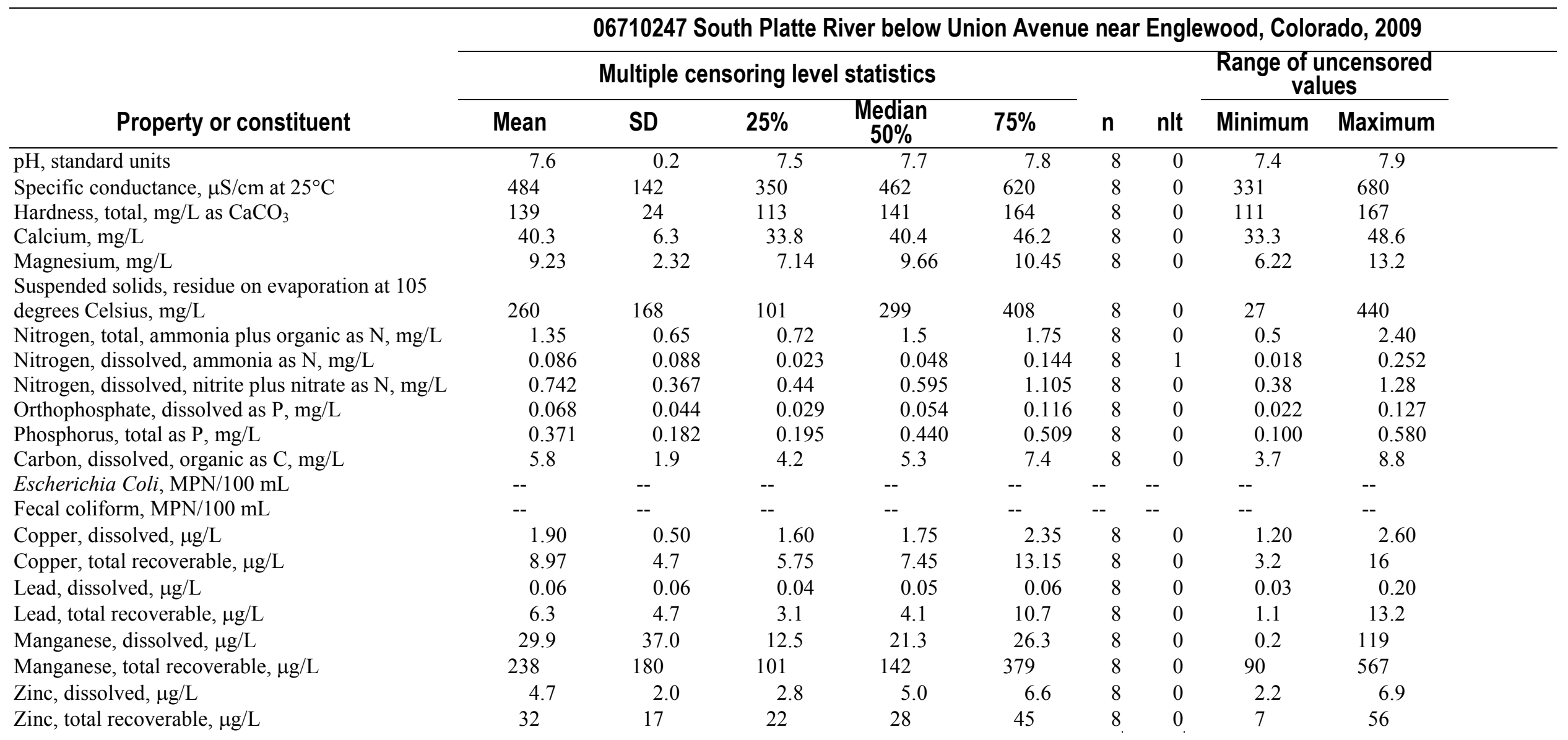


Table A1. Statistics for concentrations and measurement values at South Platte River below Union Avenue at Englewood, 2006-2010.-Continued

$\left[\mu \mathrm{S} / \mathrm{cm}\right.$ at $25^{\circ} \mathrm{C}$, microsiemens per centimeter at 25 degrees Celsius; $\mathrm{mL}$, milliliter; $\mathrm{CaCO}_{3}$, calcium carbonate; $\mathrm{mg} / \mathrm{L}$, milligrams per liter; $\mu \mathrm{g} / \mathrm{L}$, micrograms per liter; mm, millimeter; N, nitrogen; P, phosphorus; C, carbon; SD, standard deviation; n, number of samples; nlt, number of "less thans" or censored data; \%, percentile; MPN, most probable number; --, not computed; multiple censoring level statistics uses log-probability regression on values greater than the censoring level to predict statistics that are affected by the censoring level (mean, standard deviation, and 25th percentile; conventional univariate statistics are used when no censored values are used; multiple detection limit techniques are used when censored values are part of the data for a particular value or concentration]

\begin{tabular}{|c|c|c|c|c|c|c|c|c|c|}
\hline \multirow[b]{3}{*}{ Property or constituent } & \multicolumn{9}{|c|}{06710247 South Platte River below Union Avenue near Englewood, Colorado, 2010} \\
\hline & \multicolumn{5}{|c|}{ Multiple censoring level statistics } & \multirow[b]{2}{*}{ n } & \multirow[b]{2}{*}{ nlt } & \multicolumn{2}{|c|}{$\begin{array}{l}\text { Range of uncensored } \\
\text { values }\end{array}$} \\
\hline & Mean & SD & $25 \%$ & $\begin{array}{l}\text { Median } \\
50 \%\end{array}$ & $75 \%$ & & & Minimum & Maximum \\
\hline $\mathrm{pH}$, standard units & 7.6 & 0.2 & 7.6 & 7.6 & 7.7 & 11 & 0 & 6.9 & 7.8 \\
\hline Specific conductance, $\mu \mathrm{S} / \mathrm{cm}$ at $25^{\circ} \mathrm{C}$ & 558 & 282 & 330 & 419 & 923 & 11 & 0 & 226 & 955 \\
\hline Hardness, total, $\mathrm{mg} / \mathrm{L}$ as $\mathrm{CaCO}_{3}$ & 166 & 63 & 120 & 135 & 223 & 11 & 0 & 97 & 290 \\
\hline Calcium, $\mathrm{mg} / \mathrm{L}$ & 48.6 & 17.4 & 36.2 & 41.0 & 63.2 & 11 & 0 & 29.5 & 83.8 \\
\hline Magnesium, mg/L & 10.81 & 4.72 & 7.15 & 8.68 & 15.8 & 11 & 0 & 5.71 & 19.6 \\
\hline $\begin{array}{l}\text { Suspended solids, residue on evaporation at } 105 \\
\text { degrees Celsius, } \mathrm{mg} / \mathrm{L}\end{array}$ & 250 & 219 & 110 & 220 & 284 & 11 & 1 & 46 & 670 \\
\hline Nitrogen, total, ammonia plus organic as $\mathrm{N}, \mathrm{mg} / \mathrm{L}$ & 1.52 & 0.6 & 1.1 & 1.4 & 1.7 & 11 & 0 & 0.83 & 2.80 \\
\hline Nitrogen, dissolved, ammonia as $\mathrm{N}, \mathrm{mg} / \mathrm{L}$ & 0.02 & 0.018 & 0.006 & 0.012 & 0.031 & 11 & 4 & 0.012 & 0.058 \\
\hline Nitrogen, dissolved, nitrite plus nitrate as $\mathrm{N}, \mathrm{mg} / \mathrm{L}$ & 1.063 & 0.829 & 0.5 & 0.59 & 1.37 & 11 & 0 & 0.41 & 2.71 \\
\hline Orthophosphate, dissolved as $\mathrm{P}, \mathrm{mg} / \mathrm{L}$ & 0.058 & 0.080 & 0.010 & 0.022 & 0.053 & 11 & 0 & 0.004 & 0.237 \\
\hline Phosphorus, total as $\mathrm{P}, \mathrm{mg} / \mathrm{L}$ & 0.426 & 0.262 & 0.240 & 0.350 & 0.430 & 11 & 0 & 0.210 & 0.980 \\
\hline Carbon, dissolved, organic as $\mathrm{C}, \mathrm{mg} / \mathrm{L}$ & 5.8 & 1.0 & 4.8 & 5.5 & 6.5 & 11 & 0 & 4.4 & 7.7 \\
\hline Escherichia Coli, MPN/100 mL & -- & -- & -- & -- & -- & 1 & 0 & 20 & -- \\
\hline Fecal coliform, MPN/100 mL & -- & -- & -- & -- & -- & 1 & 0 & 20 & -- \\
\hline Copper, dissolved, $\mu \mathrm{g} / \mathrm{L}$ & 2.44 & 0.85 & 1.70 & 2.60 & 2.90 & 11 & 0 & 1.40 & 4.00 \\
\hline Copper, total recoverable, $\mu \mathrm{g} / \mathrm{L}$ & 13.7 & 9.3 & 7.4 & 12.2 & 14.4 & 9 & 0 & 3.1 & 30.4 \\
\hline Lead, dissolved, $\mu \mathrm{g} / \mathrm{L}$ & 0.10 & 0.07 & 0.06 & 0.06 & 0.14 & 11 & 0 & 0.03 & 0.27 \\
\hline Lead, total recoverable, $\mu \mathrm{g} / \mathrm{L}$ & 9.9 & 8.5 & 4.6 & 8.2 & 10.8 & 9 & 0 & 0.6 & 26.9 \\
\hline Manganese, dissolved, $\mu \mathrm{g} / \mathrm{L}$ & 10.5 & 8.7 & 2.5 & 7.6 & 16.9 & 11 & 0 & 0.5 & 28.4 \\
\hline Manganese, total recoverable, $\mu \mathrm{g} / \mathrm{L}$ & 364 & 273 & 176 & 267 & 430 & 9 & 0 & 91 & 884 \\
\hline Zinc, dissolved, $\mu \mathrm{g} / \mathrm{L}$ & 6.86 & 4.37 & 2.6 & 5.3 & 9.7 & 11 & 0 & 1.8 & 13.6 \\
\hline Zinc, total recoverable, $\mu \mathrm{g} / \mathrm{L}$ & 49.1 & 32.0 & 29.3 & 39.1 & 59.8 & 9 & 0 & 10.6 & 108 \\
\hline
\end{tabular}


Table A2. Statistics for concentrations and measurement values at South Platte River at Denver by year, 2006-2010.

$\left[\mu \mathrm{S} / \mathrm{cm}\right.$, microsiemens per centimeter at 25 degrees Celsius; $\mathrm{ml}$, milliliter; $\mathrm{CaCO}_{3}$, calcium carbonate; $\mathrm{mg} / \mathrm{L}$, milligrams per liter; $\mu \mathrm{g} / \mathrm{L}$, micrograms per liter; mm, millimeter; $\mathrm{N}$, nitrogen; $\mathrm{P}$, phosphorus; $\mathrm{C}$, carbon; SD, standard deviation; n, number of samples; nlt, number of "less thans" or censored data; \%, percentile; MPN, most probable number; --, not computed]

06714000 South Platte River at Denver, Colorado, 2006

\begin{tabular}{|c|c|c|c|c|c|c|c|c|c|}
\hline \multirow{2}{*}{ Property or constituent } & \multicolumn{5}{|c|}{ Multiple censoring level statistics } & \multicolumn{4}{|c|}{$\begin{array}{c}\text { Range of uncensored } \\
\text { values }\end{array}$} \\
\hline & \multirow{2}{*}{ Mean } & \multirow{2}{*}{$\frac{\text { SD }}{0.2}$} & \multirow{2}{*}{$\begin{array}{r}25 \% \\
7.5\end{array}$} & \multirow{2}{*}{$\begin{array}{c}\begin{array}{c}\text { Median } \\
\mathbf{5 0 \%}\end{array} \\
7.7\end{array}$} & \multirow{2}{*}{$\begin{array}{r}75 \% \\
7.7\end{array}$} & $\mathrm{n}$ & nlt & \multirow{2}{*}{$\begin{array}{c}\text { Minimum } \\
7.3\end{array}$} & \multirow{2}{*}{$\begin{array}{c}\text { Maximum } \\
7.9\end{array}$} \\
\hline $\mathrm{pH}$, standard units & & & & & & 6 & 0 & & \\
\hline Specific conductance, $\mu \mathrm{S} / \mathrm{cm}$ at $25^{\circ} \mathrm{C}$ & 408 & 42 & 375 & 416 & 439 & 4 & 0 & 349 & 447 \\
\hline Hardness, total, $\mathrm{mg} / \mathrm{L}$ as $\mathrm{CaCO}_{3}$ & 141 & 38 & 121 & 129 & 159 & 6 & 0 & 99.3 & 209 \\
\hline Calcium, $\mathrm{mg} / \mathrm{L}$ & 42.4 & 9.9 & 37.2 & 39.6 & 48.5 & 6 & 0 & 30.6 & 59 \\
\hline Magnesium, mg/L & 8.51 & 3.34 & 6.89 & 7.25 & 9.24 & 6 & 0 & 5.57 & 14.9 \\
\hline $\begin{array}{l}\text { Suspended solids, residue on evaporation at } 105 \\
\text { degrees Celsius, } \mathrm{mg} / \mathrm{L}\end{array}$ & 189 & 50 & 166 & 186 & 220 & 6 & 0 & 115 & 260 \\
\hline Nitrogen, total, ammonia plus organic as $\mathrm{N}, \mathrm{mg} / \mathrm{L}$ & 1.9 & 1.0 & 1.3 & 1.5 & 2.0 & 6 & 0 & 1.1 & 3.9 \\
\hline Nitrogen, dissolved, ammonia as $\mathrm{N}, \mathrm{mg} / \mathrm{L}$ & 0.192 & 0.200 & 0.095 & 0.119 & 0.131 & 6 & 0 & 0.087 & 0.600 \\
\hline Nitrogen, dissolved, nitrite plus nitrate as $\mathrm{N}, \mathrm{mg} / \mathrm{L}$ & 1.56 & 1.07 & 0.91 & 1.21 & 1.49 & 6 & 0 & 0.83 & 3.69 \\
\hline Orthophosphate, dissolved as $\mathrm{P}, \mathrm{mg} / \mathrm{L}$ & 0.179 & 0.089 & 0.121 & 0.147 & 0.197 & 6 & 0 & 0.110 & 0.349 \\
\hline Phosphorus, total as $\mathrm{P}, \mathrm{mg} / \mathrm{L}$ & 0.57 & 0.26 & 0.39 & 0.51 & 0.62 & 6 & 0 & 0.35 & 1.07 \\
\hline Carbon, dissolved, organic as $\mathrm{C}, \mathrm{mg} / \mathrm{L}$ & 6.38 & 2.74 & 5 & 5.7 & 6 & 6 & 0 & 4.1 & 11.8 \\
\hline Escherichia Coli, MPN/100 mL & -- & -- & -- & -- & -- & 1 & 0 & 7,900 & -- \\
\hline Fecal coliform, MPN/100 mL & -- & -- & -- & -- & -- & 1 & 0 & 7,900 & -- \\
\hline Copper, dissolved, $\mu \mathrm{g} / \mathrm{L}$ & 2.2 & 0.5 & 1.8 & 2.1 & 2.5 & 6 & 0 & 1.5 & 3.2 \\
\hline Copper, total recoverable, $\mu \mathrm{g} / \mathrm{L}$ & 16.6 & 6.3 & 12.0 & 16.4 & 18.2 & 6 & 0 & 9.0 & 27.3 \\
\hline Lead, dissolved, $\mu \mathrm{g} / \mathrm{L}$ & 0.10 & 0.07 & 0.06 & 0.08 & 0.13 & 6 & 0 & 0.04 & 0.24 \\
\hline Lead, total recoverable, $\mu \mathrm{g} / \mathrm{L}$ & 12.2 & 4.3 & 8.2 & 13.4 & 15.4 & 6 & 0 & 6.0 & 17.0 \\
\hline Manganese, dissolved, $\mu \mathrm{g} / \mathrm{L}$ & 27.7 & 62.9 & 1.4 & 2.1 & 3.5 & 6 & 0 & 1.1 & 156.0 \\
\hline Manganese, total recoverable, $\mu \mathrm{g} / \mathrm{L}$ & 337 & 93 & 272 & 297 & 412 & 6 & 0 & 254 & 487 \\
\hline Zinc, dissolved, $\mu \mathrm{g} / \mathrm{L}$ & 7.9 & 6.6 & 4.9 & 5.6 & 6.3 & 6 & 0 & 3.7 & 21.1 \\
\hline Zinc, total recoverable, $\mu \mathrm{g} / \mathrm{L}$ & 64 & 32 & 40 & 63 & 68 & 6 & 0 & 30 & 121 \\
\hline
\end{tabular}


Table A2. Statistics for concentrations and measurement values at South Platte River at Denver by year, 2006-2010.-Continued

$\left[\mu \mathrm{S} / \mathrm{cm}\right.$, microsiemens per centimeter at 25 degrees Celsius; $\mathrm{ml}$, milliliter; $\mathrm{CaCO}_{3}$, calcium carbonate; $\mathrm{mg} / \mathrm{L}$, milligrams per liter; $\mu \mathrm{g} / \mathrm{L}$, micrograms per liter; mm, millimeter; $\mathrm{N}$, nitrogen; $\mathrm{P}$, phosphorus; $\mathrm{C}$, carbon; SD, standard deviation; n, number of samples; nlt, number of "less thans" or censored data; \%, percentile; MPN, most probable number; --, not computed]

06714000 South Platte River at Denver, Colorado, 2007

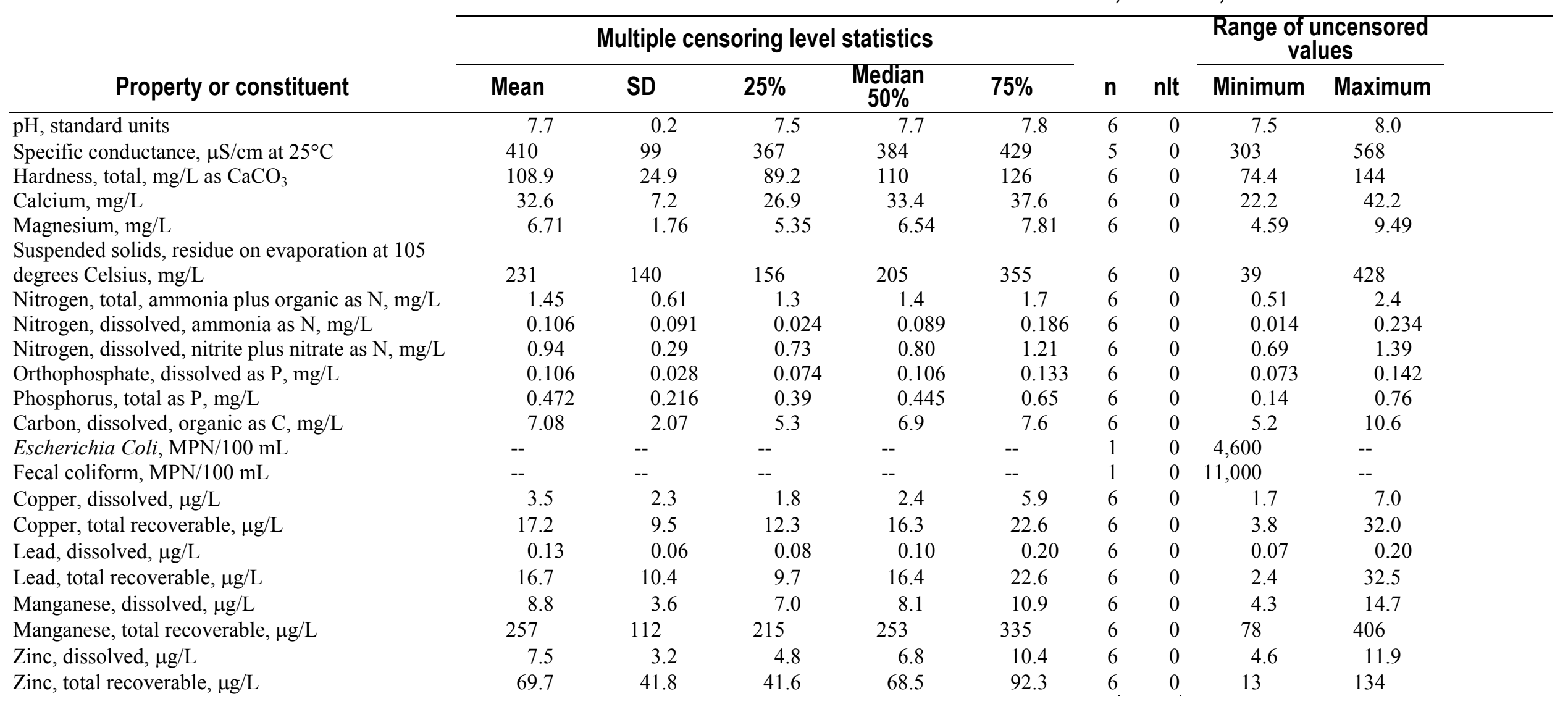


Table A2. Statistics for concentrations and measurement values at South Platte River at Denver by year, 2006-2010.-Continued

$\left[\mu \mathrm{S} / \mathrm{cm}\right.$, microsiemens per centimeter at 25 degrees Celsius; $\mathrm{ml}$, milliliter; $\mathrm{CaCO}_{3}$, calcium carbonate; $\mathrm{mg} / \mathrm{L}$, milligrams per liter; $\mu \mathrm{g} / \mathrm{L}$, micrograms per liter; mm, millimeter; $\mathrm{N}$, nitrogen; $\mathrm{P}$, phosphorus; $\mathrm{C}$, carbon; SD, standard deviation; n, number of samples; nlt, number of "less thans" or censored data; \%, percentile; MPN, most probable number; --, not computed]

\begin{tabular}{|c|c|c|c|c|c|c|c|c|c|}
\hline \multirow[b]{3}{*}{ Property or constituent } & \multicolumn{9}{|c|}{06714000 South Platte River at Denver, Colorado, 2008} \\
\hline & \multicolumn{5}{|c|}{ Multiple censoring level statistics } & \multirow[b]{2}{*}{$\mathbf{n}$} & \multirow[b]{2}{*}{ nlt } & \multicolumn{2}{|c|}{$\begin{array}{l}\text { Range of uncensored } \\
\text { values }\end{array}$} \\
\hline & Mean & SD & $25 \%$ & $\begin{array}{l}\text { Median } \\
50 \%\end{array}$ & $75 \%$ & & & Minimum & Maximum \\
\hline $\mathrm{pH}$, standard units & 7.6 & 0.3 & 7.4 & 7.6 & 7.8 & 4 & 0 & 7.2 & 7.8 \\
\hline Specific conductance, $\mu \mathrm{S} / \mathrm{cm}$ at $25^{\circ} \mathrm{C}$ & 377 & 112 & 291 & 363 & 462 & 4 & 0 & 260 & 520 \\
\hline Hardness, total, $\mathrm{mg} / \mathrm{L}$ as $\mathrm{CaCO}_{3}$ & 104 & 29 & 83 & 96 & 125 & 4 & 0 & 78.4 & 146 \\
\hline Calcium, $\mathrm{mg} / \mathrm{L}$ & 31.4 & 8.1 & 25.6 & 29.2 & 37.2 & 4 & 0 & 24.4 & 42.8 \\
\hline Magnesium, mg/L & 6.26 & 2.25 & 4.77 & 5.66 & 7.75 & 4 & 0 & 4.26 & 9.47 \\
\hline $\begin{array}{l}\text { Suspended solids, residue on evaporation at } 105 \\
\text { degrees Celsius, } \mathrm{mg} / \mathrm{L}\end{array}$ & 267 & 199 & 105 & 242 & 428 & 4 & 0 & 74 & 510 \\
\hline Nitrogen, total, ammonia plus organic as $\mathrm{N}, \mathrm{mg} / \mathrm{L}$ & 2.5 & 1.6 & 1.2 & 2.4 & 3.8 & 4 & 0 & 1.0 & 4.2 \\
\hline Nitrogen, dissolved, ammonia as N, mg/L & 0.266 & 0.190 & 0.104 & 0.261 & 0.429 & 4 & 0 & 0.082 & 0.463 \\
\hline Nitrogen, dissolved, nitrite plus nitrate as $\mathrm{N}, \mathrm{mg} / \mathrm{L}$ & 1.37 & 0.43 & 1.00 & 1.36 & 1.74 & 4 & 0 & 0.97 & 1.78 \\
\hline Orthophosphate, dissolved as $\mathrm{P}, \mathrm{mg} / \mathrm{L}$ & 0.183 & 0.046 & 0.143 & 0.184 & 0.223 & 4 & 0 & 0.140 & 0.223 \\
\hline Phosphorus, total as $\mathrm{P}, \mathrm{mg} / \mathrm{L}$ & 0.74 & 0.46 & 0.38 & 0.64 & 1.11 & 4 & 0 & 0.36 & 1.33 \\
\hline Carbon, dissolved, organic as $\mathrm{C}, \mathrm{mg} / \mathrm{L}$ & 7.1 & 1.8 & 5.7 & 6.9 & 8.6 & 4 & 0 & 5.6 & 9.1 \\
\hline Escherichia Coli, MPN/100 mL & -- & -- & -- & -- & -- & 1 & 0 & 23,000 & -- \\
\hline Fecal coliform, MPN/100 mL & -- & -- & -- & -- & -- & 1 & 0 & 23,000 & -- \\
\hline Copper, dissolved, $\mu \mathrm{g} / \mathrm{L}$ & 2.0 & 0.6 & 1.5 & 1.9 & 2.4 & 4 & 1 & 1.7 & 2.7 \\
\hline Copper, total recoverable, $\mu \mathrm{g} / \mathrm{L}$ & 28.8 & 26.9 & 9.9 & 20.4 & 47.7 & 4 & 0 & 7.5 & 67.0 \\
\hline Lead, dissolved, $\mu \mathrm{g} / \mathrm{L}$ & 0.12 & 0.04 & 0.09 & 0.11 & 0.14 & 4 & 0 & 0.07 & 0.17 \\
\hline Lead, total recoverable, $\mu \mathrm{g} / \mathrm{L}$ & 30.2 & 34.2 & 7.4 & 18.7 & 53.0 & 4 & 0 & 4.0 & 79.5 \\
\hline Manganese, dissolved, $\mu \mathrm{g} / \mathrm{L}$ & 4.1 & 4.9 & 0.9 & 2.5 & 7.3 & 4 & 0 & 0.1 & 11.2 \\
\hline Manganese, total recoverable, $\mu \mathrm{g} / \mathrm{L}$ & 509 & 340 & 221 & 493 & 795 & 4 & 0 & 174 & 873 \\
\hline Zinc, dissolved, $\mu \mathrm{g} / \mathrm{L}$ & 6.6 & 2.0 & 5.4 & 7.4 & 7.9 & 4 & 0 & 3.7 & 8.1 \\
\hline Zinc, total recoverable, $\mu \mathrm{g} / \mathrm{L}$ & 128 & 118 & 40 & 99 & 216 & 4 & 0 & 25 & 287 \\
\hline
\end{tabular}


Table A2. Statistics for concentrations and measurement values at South Platte River at Denver by year, 2006-2010.-Continued

$\left[\mu \mathrm{S} / \mathrm{cm}\right.$, microsiemens per centimeter at 25 degrees Celsius; $\mathrm{ml}$, milliliter; $\mathrm{CaCO}_{3}$, calcium carbonate; $\mathrm{mg} / \mathrm{L}$, milligrams per liter; $\mu \mathrm{g} / \mathrm{L}$, micrograms per liter; mm, millimeter; $\mathrm{N}$, nitrogen; $\mathrm{P}$, phosphorus; $\mathrm{C}$, carbon; SD, standard deviation; n, number of samples; nlt, number of "less thans" or censored data; \%, percentile; MPN, most probable number; --, not computed]

\begin{tabular}{|c|c|c|c|c|c|c|c|c|c|}
\hline \multirow[b]{3}{*}{ Property or constituent } & \multicolumn{9}{|c|}{06714000 South Platte River at Denver, Colorado, 2009} \\
\hline & \multicolumn{5}{|c|}{ Multiple censoring level statistics } & \multirow[b]{2}{*}{$\mathbf{n}$} & \multirow[b]{2}{*}{ nlt } & \multicolumn{2}{|c|}{$\begin{array}{c}\text { Range of uncensored } \\
\text { values }\end{array}$} \\
\hline & Mean & SD & $25 \%$ & $\begin{array}{l}\text { Median } \\
50 \%\end{array}$ & $75 \%$ & & & Minimum & Maximum \\
\hline $\mathrm{pH}$, standard units & 7.5 & 0.3 & 7.5 & 7.5 & 7.8 & 6 & 0 & 6.6 & 8.0 \\
\hline Specific conductance, $\mu \mathrm{S} / \mathrm{cm}$ at $25^{\circ} \mathrm{C}$ & 509 & 140 & 394 & 524 & 620 & 16 & 0 & 295 & 721 \\
\hline Hardness, total, $\mathrm{mg} / \mathrm{L}$ as $\mathrm{CaCO}_{3}$ & 140 & 45 & 101 & 138 & 165 & 16 & 0 & 85.6 & 225 \\
\hline Magnesium, mg/L & 8.43 & 2.77 & 6.08 & 8.2 & 10.0 & 16 & 0 & 4.61 & 13.7 \\
\hline $\begin{array}{l}\text { Suspended solids, residue on evaporation at } 105 \\
\text { degrees Celsius, } \mathrm{mg} / \mathrm{L}\end{array}$ & 150 & 83 & 83 & 158 & 204 & 16 & 1 & 20.0 & 300 \\
\hline Nitrogen, total, ammonia plus organic as $\mathrm{N}, \mathrm{mg} / \mathrm{L}$ & 1.4 & 0.53 & 0.84 & 1.5 & 1.9 & 15 & 0 & 0.81 & 2.3 \\
\hline Nitrogen, dissolved, ammonia as $\mathrm{N}, \mathrm{mg} / \mathrm{L}$ & 0.076 & 0.089 & 0.021 & 0.034 & 0.123 & 15 & 2 & 0.010 & 0.300 \\
\hline Nitrogen, dissolved, nitrite plus nitrate as $\mathrm{N}, \mathrm{mg} / \mathrm{L}$ & 0.94 & 0.42 & 0.67 & 0.80 & 0.99 & 15 & 0 & 0.55 & 1.94 \\
\hline Orthophosphate, dissolved as $\mathrm{P}, \mathrm{mg} / \mathrm{L}$ & 0.152 & 0.079 & 0.103 & 0.12 & 0.168 & 15 & 0 & 0.068 & 0.368 \\
\hline Phosphorus, total as $\mathrm{P}, \mathrm{mg} / \mathrm{L}$ & 0.46 & 0.15 & 0.32 & 0.47 & 0.61 & 15 & 0 & 0.22 & 0.67 \\
\hline Escherichia Coli, MPN/100 mL & -- & -- & -- & -- & -- & -- & -- & -- & -- \\
\hline Fecal coliform, MPN/100 mL & -- & -- & -- & -- & -- & -- & -- & -- & -- \\
\hline Copper, dissolved, $\mu \mathrm{g} / \mathrm{L}$ & 2.7 & 0.9 & 2.2 & 2.4 & 2.9 & 16 & 0 & 1.5 & 4.8 \\
\hline Copper, total recoverable, $\mu \mathrm{g} / \mathrm{L}$ & 13.6 & 6.8 & 7.8 & 13.6 & 19.0 & 16 & 0 & 4.2 & 26.9 \\
\hline Lead, dissolved, $\mu \mathrm{g} / \mathrm{L}$ & 0.11 & 0.08 & 0.06 & 0.09 & 0.11 & 16 & 0 & 0.04 & 0.31 \\
\hline Lead, total recoverable, $\mu \mathrm{g} / \mathrm{L}$ & 12.2 & 8.4 & 6.0 & 9.7 & 17.8 & 16 & 0 & 2.1 & 31.0 \\
\hline Manganese, dissolved, $\mu \mathrm{g} / \mathrm{L}$ & 6.8 & 7.9 & 0.7 & 2.5 & 12.4 & 16 & 0 & 0.2 & 23.1 \\
\hline Manganese, total recoverable, $\mu \mathrm{g} / \mathrm{L}$ & 272 & 122 & 168 & 258 & 348 & 16 & 0 & 111 & 490 \\
\hline Zinc, dissolved, $\mu \mathrm{g} / \mathrm{L}$ & 7.9 & 3.8 & 4.9 & 6.8 & 10.6 & 16 & 0 & 3.3 & 15.8 \\
\hline Zinc, total recoverable, $\mu \mathrm{g} / \mathrm{L}$ & 57 & 32 & 28 & 55 & 88 & 16 & 0 & 15 & 112 \\
\hline
\end{tabular}


Table A2. Statistics for concentrations and measurement values at South Platte River at Denver by year, 2006-2010.-Continued

$\left[\mu \mathrm{S} / \mathrm{cm}\right.$, microsiemens per centimeter at 25 degrees Celsius; $\mathrm{ml}$, milliliter; $\mathrm{CaCO}_{3}$, calcium carbonate; $\mathrm{mg} / \mathrm{L}$, milligrams per liter; $\mu \mathrm{g} / \mathrm{L}$, micrograms per liter; mm, millimeter; $\mathrm{N}$, nitrogen; $\mathrm{P}$, phosphorus; $\mathrm{C}$, carbon; SD, standard deviation; n, number of samples; nlt, number of "less thans" or censored data; \%, percentile; MPN, most probable number; --, not computed]

\begin{tabular}{|c|c|c|c|c|c|c|c|c|c|}
\hline \multirow[b]{3}{*}{ Property or constituent } & \multicolumn{9}{|c|}{06714000 South Platte River at Denver, Colorado, 2010} \\
\hline & \multicolumn{5}{|c|}{ Multiple censoring level statistics } & \multirow[b]{2}{*}{$\mathbf{n}$} & \multirow[b]{2}{*}{ nlt } & \multicolumn{2}{|c|}{$\begin{array}{l}\text { Range of uncensored } \\
\text { values }\end{array}$} \\
\hline & Mean & SD & $25 \%$ & $\begin{array}{l}\text { Median } \\
50 \% \\
\end{array}$ & $75 \%$ & & & Minimum & Maximum \\
\hline $\mathrm{pH}$, standard units & 7.5 & 0.3 & 7.4 & 7.5 & 7.6 & 16 & 0 & 7.0 & 8.0 \\
\hline Specific conductance, $\mu \mathrm{S} / \mathrm{cm}$ at $25^{\circ} \mathrm{C}$ & 627 & 308 & 409 & 537 & 613 & 17 & 0 & 294 & 1,390 \\
\hline Hardness, total, mg/L as $\mathrm{CaCO}_{3}$ & 163 & 40 & 138 & 156 & 176 & 16 & 0 & 110 & 251 \\
\hline Calcium, mg/L & 48.2 & 10.7 & 42 & 47 & 53.1 & 16 & 0 & 34.2 & 75.9 \\
\hline Magnesium, mg/L & 10.2 & 3.49 & 7.97 & 9.53 & 10.8 & 16 & 0 & 6.00 & 17.7 \\
\hline $\begin{array}{l}\text { Suspended solids, residue on evaporation at } 105 \\
\text { degrees Celsius, } \mathrm{mg} / \mathrm{L}\end{array}$ & 230 & 146 & 138 & 197 & 301 & 16 & 0 & 50 & 660 \\
\hline Nitrogen, total, ammonia plus organic as $\mathrm{N}, \mathrm{mg} / \mathrm{L}$ & 2.0 & 0.71 & 1.4 & 1.9 & 2.4 & 16 & 0 & 0.82 & 3.2 \\
\hline Nitrogen, dissolved, ammonia as $\mathrm{N}, \mathrm{mg} / \mathrm{L}$ & 0.095 & 0.111 & 0.029 & 0.044 & 0.117 & 16 & 2 & 0.024 & 0.395 \\
\hline Nitrogen, dissolved, nitrite plus nitrate as $\mathrm{N}, \mathrm{mg} / \mathrm{L}$ & 1.415 & 0.712 & 0.93 & 1.27 & 1.5 & 15 & 0 & 0.71 & 3.44 \\
\hline Orthophosphate, dissolved as $\mathrm{P}, \mathrm{mg} / \mathrm{L}$ & 0.149 & 0.113 & 0.084 & 0.109 & 0.166 & 16 & 0 & 0.046 & 0.487 \\
\hline Phosphorus, total as $\mathrm{P}, \mathrm{mg} / \mathrm{L}$ & 0.56 & 0.22 & 0.40 & 0.53 & 0.71 & 16 & 0 & 0.19 & 1.04 \\
\hline Carbon, dissolved, organic as $\mathrm{C}, \mathrm{mg} / \mathrm{L}$ & 6.2 & 1.6 & 5.0 & 6.1 & 7.2 & 16 & 0 & 4.1 & 9.8 \\
\hline Escherichia Coli, MPN/100 mL & -- & -- & -- & -- & -- & 1 & 0 & 110 & -- \\
\hline Fecal coliform, MPN/100 mL & -- & -- & -- & -- & -- & 1 & 0 & 170 & -- \\
\hline Copper, dissolved, $\mu \mathrm{g} / \mathrm{L}$ & 3.3 & 1.1 & 2.4 & 3.1 & 3.7 & 16 & 0 & 2.0 & 6.2 \\
\hline Copper, total recoverable, $\mu \mathrm{g} / \mathrm{L}$ & 17.4 & 10.6 & 10.5 & 15.1 & 21.2 & 13 & 0 & 5.2 & 41.8 \\
\hline Lead, dissolved, $\mu \mathrm{g} / \mathrm{L}$ & 0.13 & 0.05 & 0.08 & 0.12 & 0.16 & 16 & 0 & 0.06 & 0.23 \\
\hline Lead, total recoverable, $\mu \mathrm{g} / \mathrm{L}$ & 15.0 & 12.9 & 6.7 & 11.3 & 16.5 & 13 & 0 & 2.1 & 50.2 \\
\hline Manganese, dissolved, $\mu \mathrm{g} / \mathrm{L}$ & 10.0 & 22.1 & 1.0 & 3.1 & 6.8 & 16 & 0 & 0.6 & 90.1 \\
\hline Manganese, total recoverable, $\mu \mathrm{g} / \mathrm{L}$ & 391 & 211 & 244 & 319 & 608 & 13 & 0 & 97 & 741 \\
\hline Zinc, dissolved, $\mu \mathrm{g} / \mathrm{L}$ & 9.5 & 5.2 & 5.4 & 8.6 & 13.3 & 16 & 0 & 3.4 & 21.3 \\
\hline Zinc, total recoverable, $\mu \mathrm{g} / \mathrm{L}$ & 76 & 49 & 35 & 70 & 89 & 13 & 0 & 22 & 183 \\
\hline
\end{tabular}


Table A3. Statistics for concentrations and measurement values at Toll Gate Creek above 6th Avenue at Aurora by year, 2006-2010.

$\left[\mu \mathrm{S} / \mathrm{cm}\right.$, microsiemens per centimeter at 25 degrees Celsius; ml, milliliter; $\mathrm{CaCO}_{3}$, calcium carbonate; $\mathrm{mg} / \mathrm{L}$, milligrams per liter; $\mu \mathrm{g} / \mathrm{L}$, micrograms per liter; mm, millimeter; N, nitrogen; P, phosphorus; $\mathrm{C}$, carbon; SD, standard deviation; n, number of samples; nlt, number of "less thans" or censored data; \%, percentile; MPN, most probable number; --, not computed]

394329104490101 Toll Gate Creek above 6th Avenue at Aurora, Colorado, 2006

\begin{tabular}{|c|c|c|c|c|c|c|c|c|c|}
\hline \multirow[b]{3}{*}{ Property or constituent } & \multicolumn{9}{|c|}{ enue at Aurora, Colora } \\
\hline & \multicolumn{5}{|c|}{ Multiple censoring level statistics } & \multirow[b]{2}{*}{$\mathbf{n}$} & \multirow[b]{2}{*}{ nlt } & \multicolumn{2}{|c|}{$\begin{array}{c}\text { Range of uncensored } \\
\text { values }\end{array}$} \\
\hline & Mean & SD & $25 \%$ & $\begin{array}{c}\text { Median } \\
50 \%\end{array}$ & $75 \%$ & & & Minimum & Maximum \\
\hline $\mathrm{pH}$, standard units & 7.6 & 0.1 & 7.5 & 7.6 & 7.8 & 7 & 0 & 7.5 & 7.8 \\
\hline Specific conductance, $\mu \mathrm{S} / \mathrm{cm}$ at $25^{\circ} \mathrm{C}$ & 1,090 & 579 & 643 & 780 & 1,950 & 7 & 0 & 587 & 2,210 \\
\hline Hardness, total, $\mathrm{mg} / \mathrm{L}$ as $\mathrm{CaCO}_{3}$ & 298 & 182 & 162 & 209 & 539 & 7 & 0 & 156 & 583 \\
\hline Calcium, mg/L & 90 & 52 & 51 & 64 & 159 & 7 & 0 & 49 & 172 \\
\hline Magnesium, mg/L & 17.8 & 12.5 & 8.67 & 12.1 & 34.4 & 7 & 0 & 8.24 & 37.4 \\
\hline $\begin{array}{l}\text { Suspended solids, residue on evaporation at } 105 \\
\text { degrees Celsius, } \mathrm{mg} / \mathrm{L}\end{array}$ & 215 & 260 & 40 & 105 & 323 & 6 & 0 & 21 & 695 \\
\hline Nitrogen, total, ammonia plus organic as $\mathrm{N}, \mathrm{mg} / \mathrm{L}$ & 1.64 & 0.69 & 1.10 & 1.30 & 2.30 & 7 & 0 & 1.00 & 2.80 \\
\hline Nitrogen, dissolved, ammonia as $\mathrm{N}, \mathrm{mg} / \mathrm{L}$ & 0.087 & 0.088 & 0.011 & 0.059 & 0.166 & 7 & 0 & 0.009 & 0.230 \\
\hline Nitrogen, dissolved, nitrite plus nitrate as $\mathrm{N}, \mathrm{mg} / \mathrm{L}$ & 0.584 & 0.205 & 0.450 & 0.520 & 0.700 & 7 & 0 & 0.420 & 1.000 \\
\hline Orthophosphate, dissolved as $\mathrm{P}, \mathrm{mg} / \mathrm{L}$ & 0.018 & 0.018 & 0.005 & 0.007 & 0.034 & 7 & 0 & 0.004 & 0.052 \\
\hline Phosphorus, total as $\mathrm{P}, \mathrm{mg} / \mathrm{L}$ & 0.323 & 0.292 & 0.120 & 0.210 & 0.520 & 7 & 0 & 0.070 & 0.900 \\
\hline Carbon, dissolved, organic as $\mathrm{C}, \mathrm{mg} / \mathrm{L}$ & 12.9 & 3.8 & 11.1 & 11.9 & 14.3 & 7 & 0 & 8.6 & 20.7 \\
\hline Escherichia Coli, MPN/100 mL & -- & -- & -- & -- & -- & 1 & 0 & 3,300 & -- \\
\hline Fecal coliform, MPN/100 mL & -- & -- & -- & -- & -- & 1 & 0 & 3,300 & -- \\
\hline Copper, dissolved, $\mu \mathrm{g} / \mathrm{L}$ & 3.5 & 1.3 & 2.2 & 3.5 & 4.9 & 7 & 0 & 1.9 & 4.9 \\
\hline Copper, total recoverable, $\mu \mathrm{g} / \mathrm{L}$ & 12.6 & 9.3 & 7.0 & 8.3 & 16.8 & 7 & 0 & 6.9 & 32.0 \\
\hline Lead, dissolved, $\mu \mathrm{g} / \mathrm{L}$ & 0.127 & 0.105 & 0.04 & 0.12 & 0.18 & 7 & 1 & 0.04 & 0.31 \\
\hline Lead, total recoverable, $\mu \mathrm{g} / \mathrm{L}$ & 5.60 & 5.93 & 1.83 & 2.98 & 9.18 & 7 & 0 & 1.52 & 17.7 \\
\hline Manganese, dissolved, $\mu \mathrm{g} / \mathrm{L}$ & 93.7 & 147 & 5.0 & 11.7 & 286 & 7 & 0 & 4.7 & 330 \\
\hline Manganese, total recoverable, $\mu \mathrm{g} / \mathrm{L}$ & 367 & 229 & 184 & 365 & 583 & 7 & 0 & 128 & 751 \\
\hline Zinc, dissolved, $\mu \mathrm{g} / \mathrm{L}$ & 12.4 & 9.6 & 4.1 & 11.7 & 23.0 & 7 & 0 & 1.8 & 26.1 \\
\hline Zinc, total recoverable, $\mu \mathrm{g} / \mathrm{L}$ & 48 & 26 & 28 & 40 & 63 & 7 & 0 & 26 & 96 \\
\hline
\end{tabular}


Table A3. Statistics for concentrations and measurement values at Toll Gate Creek above 6th Avenue at Aurora by year, 2006-2010.-Continued

$\left[\mu \mathrm{S} / \mathrm{cm}\right.$, microsiemens per centimeter at 25 degrees Celsius; ml, milliliter; $\mathrm{CaCO}_{3}$, calcium carbonate; $\mathrm{mg} / \mathrm{L}$, milligrams per liter; $\mu \mathrm{g} / \mathrm{L}$, micrograms per liter; mm, millimeter; N, nitrogen; P, phosphorus; $\mathrm{C}$, carbon; SD, standard deviation; n, number of samples; nlt, number of "less thans" or censored data; \%, percentile; MPN, most probable number; --, not computed]

\begin{tabular}{|c|c|c|c|c|c|c|c|c|c|}
\hline \multirow[b]{3}{*}{ Property or constituent } & \multicolumn{9}{|c|}{394329104490101 Toll Gate Creek above 6th Avenue at Aurora, Colorado, 2007} \\
\hline & \multicolumn{5}{|c|}{ Multiple censoring level statistics } & \multirow[b]{2}{*}{$\mathbf{n}$} & \multirow[b]{2}{*}{ nlt } & \multicolumn{2}{|c|}{$\begin{array}{l}\text { Range of uncensored } \\
\text { values }\end{array}$} \\
\hline & Mean & SD & $25 \%$ & $\begin{array}{l}\text { Median } \\
50 \%\end{array}$ & $75 \%$ & & & Minimum & Maximum \\
\hline $\mathrm{pH}$, standard units & 7.7 & 0.1 & 7.6 & 7.7 & 7.9 & 12 & 0 & 7.5 & 7.9 \\
\hline Specific conductance, $\mu \mathrm{S} / \mathrm{cm}$ at $25^{\circ} \mathrm{C}$ & 999 & 442 & 720 & 922 & 1,500 & 10 & 0 & 363 & 1,710 \\
\hline Hardness, total, $\mathrm{mg} / \mathrm{L}$ as $\mathrm{CaCO}_{3}$ & 301 & 134 & 221 & 280 & 406 & 12 & 0 & 85 & 525 \\
\hline Calcium, mg/L & 91 & 39 & 68 & 85 & 123 & 12 & 0 & 26 & 158 \\
\hline Magnesium, mg/L & 18.0 & 8.85 & 12.3 & 16.5 & 24.5 & 12 & 0 & 4.60 & 32.1 \\
\hline $\begin{array}{l}\text { Suspended solids, residue on evaporation at } 105 \\
\text { degrees Celsius, mg/L }\end{array}$ & 208 & 205 & 62 & 110 & 407 & 12 & 0 & 10 & 590 \\
\hline Nitrogen, total, ammonia plus organic as $\mathrm{N}, \mathrm{mg} / \mathrm{L}$ & 1.73 & 0.91 & 1.04 & 1.40 & 2.60 & 12 & 0 & 0.74 & 3.20 \\
\hline Nitrogen, dissolved, ammonia as $\mathrm{N}, \mathrm{mg} / \mathrm{L}$ & 0.126 & 0.093 & 0.054 & 0.103 & 0.184 & 12 & 1 & 0.037 & 0.299 \\
\hline Nitrogen, dissolved, nitrite plus nitrate as $\mathrm{N}, \mathrm{mg} / \mathrm{L}$ & 0.616 & 0.136 & 0.490 & 0.625 & 0.725 & 12 & 0 & 0.410 & 0.820 \\
\hline Orthophosphate, dissolved as $\mathrm{P}, \mathrm{mg} / \mathrm{L}$ & 0.03 & 0.026 & 0.009 & 0.02 & 0.05 & 12 & 1 & 0.003 & 0.077 \\
\hline Phosphorus, total as $\mathrm{P}, \mathrm{mg} / \mathrm{L}$ & 0.460 & 0.421 & 0.120 & 0.290 & 0.700 & 12 & 0 & 0.070 & 1.38 \\
\hline Escherichia Coli, MPN/100 mL & -- & -- & -- & -- & -- & 2 & 0 & 330 & 3,300 \\
\hline Fecal coliform, MPN/100 mL & -- & -- & -- & -- & -- & 2 & 0 & 330 & 3,300 \\
\hline Copper, dissolved, $\mu \mathrm{g} / \mathrm{L}$ & 2.3 & 1.0 & 1.7 & 2.1 & 2.6 & 12 & 0 & 1.0 & 4.5 \\
\hline Copper, total recoverable, $\mu \mathrm{g} / \mathrm{L}$ & 14.9 & 11.0 & 6.7 & 10.2 & 25.4 & 12 & 0 & 3.0 & 32.8 \\
\hline Lead, dissolved, $\mu \mathrm{g} / \mathrm{L}$ & 0.11 & 0.08 & 0.07 & 0.09 & 0.12 & 12 & 1 & 0.06 & 0.34 \\
\hline Lead, total recoverable, $\mu \mathrm{g} / \mathrm{L}$ & 10.4 & 10.5 & 2.85 & 5.09 & 19.7 & 12 & 0 & 0.71 & 28.3 \\
\hline Manganese, dissolved, $\mu \mathrm{g} / \mathrm{L}$ & 69.0 & 55.3 & 29.9 & 49.9 & 112 & 12 & 0 & 2.8 & 165 \\
\hline Manganese, total recoverable, $\mu \mathrm{g} / \mathrm{L}$ & 432 & 302 & 202 & 276 & 715 & 12 & 0 & 111 & 940 \\
\hline Zinc, dissolved, $\mu \mathrm{g} / \mathrm{L}$ & 7.8 & 2.5 & 5.9 & 8.1 & 9.2 & 2 & 0 & 4.1 & 12.6 \\
\hline Zinc, total recoverable, $\mu \mathrm{g} / \mathrm{L}$ & 56.1 & 46.8 & 23.4 & 34.7 & 101 & 12 & 0 & 9.3 & 132 \\
\hline
\end{tabular}


Table A3. Statistics for concentrations and measurement values at Toll Gate Creek above 6th Avenue at Aurora by year, 2006-2010.-Continued

$\left[\mu \mathrm{S} / \mathrm{cm}\right.$, microsiemens per centimeter at 25 degrees Celsius; $\mathrm{ml}$, milliliter; $\mathrm{CaCO}_{3}$, calcium carbonate; $\mathrm{mg} / \mathrm{L}$, milligrams per liter; $\mu \mathrm{g} / \mathrm{L}$, micrograms per liter; mm, millimeter; N, nitrogen; P, phosphorus; $\mathrm{C}$, carbon; SD, standard deviation; n, number of samples; nlt, number of "less thans" or censored data; \%, percentile; MPN, most probable number; --, not computed]

\begin{tabular}{|c|c|c|c|c|c|c|c|c|c|}
\hline \multirow[b]{3}{*}{ Property or constituent } & \multicolumn{9}{|c|}{394329104490101 Toll Gate Creek above 6th Avenue at Aurora, Colorado, 2008} \\
\hline & \multicolumn{5}{|c|}{ Multiple censoring level statistics } & \multirow[b]{2}{*}{$\mathrm{n}$} & \multirow[b]{2}{*}{ nlt } & \multicolumn{2}{|c|}{$\begin{array}{l}\text { Range of uncensored } \\
\text { values }\end{array}$} \\
\hline & Mean & SD & $25 \%$ & $\begin{array}{l}\text { Median } \\
50 \%\end{array}$ & $75 \%$ & & & Minimum & Maximum \\
\hline $\mathrm{pH}$, standard units & 7.6 & 0.3 & 7.4 & 7.5 & 8.0 & 6 & 0 & 7.4 & 8.0 \\
\hline Specific conductance, $\mu \mathrm{S} / \mathrm{cm}$ at $25^{\circ} \mathrm{C}$ & 1,080 & 244 & 905 & 992 & 1,220 & 6 & 0 & 860 & 1,510 \\
\hline Hardness, total, $\mathrm{mg} / \mathrm{L}$ as $\mathrm{CaCO}_{3}$ & 265 & 98 & 186 & 228 & 381 & 6 & 0 & 172 & 396 \\
\hline Magnesium, mg/L & 16.1 & 6.21 & 11.4 & 13.3 & 22.8 & 6 & 0 & 10.8 & 25.0 \\
\hline $\begin{array}{l}\text { Suspended solids, residue on evaporation at } 105 \\
\text { degrees Celsius, mg/L }\end{array}$ & 152 & 188 & 46 & 97 & 102 & 5 & 0 & 31 & 484 \\
\hline Nitrogen, total, ammonia plus organic as $\mathrm{N}, \mathrm{mg} / \mathrm{L}$ & 1.62 & 1.03 & 0.78 & 1.50 & 1.80 & 6 & 0 & 0.63 & 3.50 \\
\hline Nitrogen, dissolved, ammonia as $\mathrm{N}, \mathrm{mg} / \mathrm{L}$ & 0.331 & 0.204 & 0.159 & 0.300 & 0.462 & 6 & 0 & 0.110 & 0.655 \\
\hline Nitrogen, dissolved, nitrite plus nitrate as $\mathrm{N}, \mathrm{mg} / \mathrm{L}$ & 0.723 & 0.161 & 0.580 & 0.695 & 0.830 & 6 & 0 & 0.570 & 0.970 \\
\hline Orthophosphate, dissolved as $\mathrm{P}, \mathrm{mg} / \mathrm{L}$ & 0.021 & 0.014 & 0.010 & 0.021 & 0.028 & 6 & 0 & 0.003 & 0.044 \\
\hline Phosphorus, total as $\mathrm{P}, \mathrm{mg} / \mathrm{L}$ & 0.242 & 0.192 & 0.110 & 0.215 & 0.230 & 6 & 0 & 0.070 & 0.610 \\
\hline Escherichia Coli, MPN/100 mL & -- & -- & -- & -- & -- & -- & -- & -- & -- \\
\hline Fecal coliform, MPN/100 mL & -- & -- & -- & -- & -- & -- & -- & -- & -- \\
\hline Copper, dissolved, $\mu \mathrm{g} / \mathrm{L}$ & 1.7 & 0.5 & 1.3 & 1.8 & 2.1 & 6 & 0 & 1.1 & 2.3 \\
\hline Copper, total recoverable, $\mu \mathrm{g} / \mathrm{L}$ & 9.2 & 7.2 & 5.0 & 7.3 & 9.7 & 6 & 0 & 2.9 & 23.1 \\
\hline Lead, dissolved, $\mu \mathrm{g} / \mathrm{L}$ & 0.08 & 0.04 & 0.05 & 0.08 & 0.11 & 6 & 2 & 0.05 & 0.12 \\
\hline Lead, total recoverable, $\mu \mathrm{g} / \mathrm{L}$ & 5.61 & 5.70 & 2.93 & 3.38 & 5.70 & 6 & 0 & 1.38 & 16.9 \\
\hline Manganese, dissolved, $\mu \mathrm{g} / \mathrm{L}$ & 114 & 45.2 & 91.5 & 113 & 130 & 6 & 0 & 50.9 & 187 \\
\hline Manganese, total recoverable, $\mu \mathrm{g} / \mathrm{L}$ & 377 & 371 & 159 & 242 & 351 & 6 & 0 & 149 & 1,120 \\
\hline Zinc, dissolved, $\mu \mathrm{g} / \mathrm{L}$ & 7.95 & 3.72 & 6.5 & 8.45 & 11.1 & 6 & 0 & 1.5 & 11.7 \\
\hline Zinc, total recoverable, $\mu \mathrm{g} / \mathrm{L}$ & 39.5 & 31.4 & 23.6 & 27.1 & 45.5 & 6 & 0 & 13.4 & 100 \\
\hline
\end{tabular}


Table A3. Statistics for concentrations and measurement values at Toll Gate Creek above 6th Avenue at Aurora by year, 2006-2010.-Continued

$\left[\mu \mathrm{S} / \mathrm{cm}\right.$, microsiemens per centimeter at 25 degrees Celsius; ml, milliliter; $\mathrm{CaCO}_{3}$, calcium carbonate; $\mathrm{mg} / \mathrm{L}$, milligrams per liter; $\mu \mathrm{g} / \mathrm{L}$, micrograms per liter; mm, millimeter; N, nitrogen; P, phosphorus; $\mathrm{C}$, carbon; SD, standard deviation; n, number of samples; nlt, number of "less thans" or censored data; \%, percentile; MPN, most probable number; --, not computed]

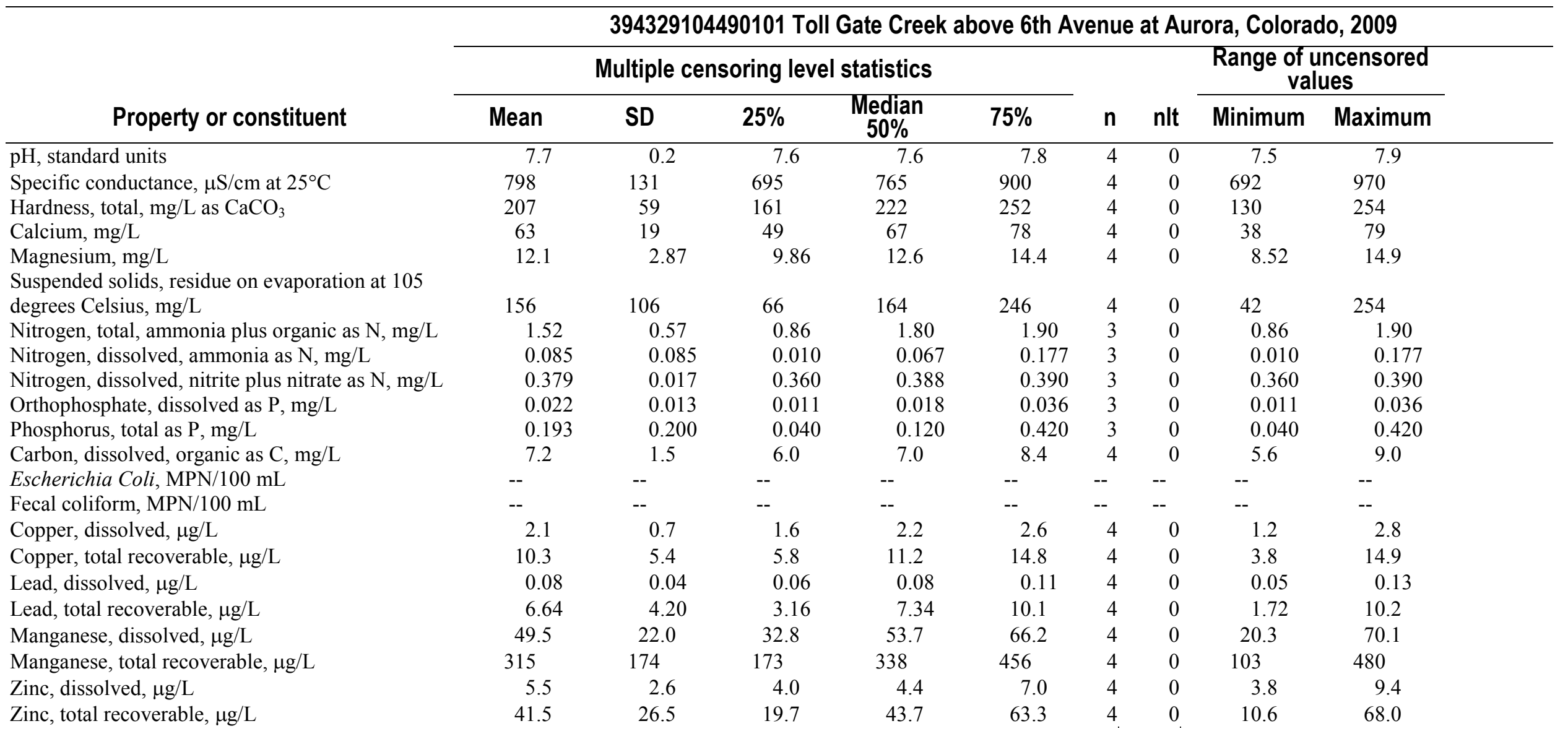


Table A3. Statistics for concentrations and measurement values at Toll Gate Creek above 6th Avenue at Aurora by year, 2006-2010.-Continued

$\left[\mu \mathrm{S} / \mathrm{cm}\right.$, microsiemens per centimeter at 25 degrees Celsius; ml, milliliter; $\mathrm{CaCO}_{3}$, calcium carbonate; $\mathrm{mg} / \mathrm{L}$, milligrams per liter; $\mu \mathrm{g} / \mathrm{L}$, micrograms per liter; mm, millimeter; N, nitrogen; P, phosphorus; $\mathrm{C}$, carbon; SD, standard deviation; n, number of samples; nlt, number of "less thans" or censored data; \%, percentile; MPN, most probable number; --, not computed]

\begin{tabular}{|c|c|c|c|c|c|c|c|c|c|}
\hline \multirow[b]{3}{*}{ Property or constituent } & \multicolumn{9}{|c|}{394329104490101 Toll Gate Creek above 6th Avenue at Aurora, Colorado, 2010} \\
\hline & \multicolumn{5}{|c|}{ Multiple censoring level statistics } & \multirow[b]{2}{*}{$\mathbf{n}$} & \multirow[b]{2}{*}{ nlt } & \multicolumn{2}{|c|}{$\begin{array}{l}\text { Range of uncensored } \\
\text { values }\end{array}$} \\
\hline & Mean & SD & $25 \%$ & $\begin{array}{l}\text { Median } \\
50 \%\end{array}$ & $75 \%$ & & & Minimum & Maximum \\
\hline $\mathrm{pH}$, standard units & 7.6 & 0.1 & 7.6 & 7.6 & 7.7 & 4 & 0 & 7.5 & 7.7 \\
\hline Specific conductance, $\mu \mathrm{S} / \mathrm{cm}$ at $25^{\circ} \mathrm{C}$ & 1,757 & 464 & 1,360 & 1,740 & 2,155 & 4 & 0 & 1,320 & 2,230 \\
\hline Hardness, total, $\mathrm{mg} / \mathrm{L}$ as $\mathrm{CaCO}_{3}$ & 579 & 178 & 425 & 576 & 733 & 4 & 0 & 418 & 746 \\
\hline Calcium, mg/L & 177 & 53 & 131 & 177 & 223 & 4 & 0 & 129 & 226 \\
\hline Magnesium, mg/L & 33.3 & 11.2 & 23.7 & 32.9 & 43.0 & 4 & 0 & 23.2 & 44.4 \\
\hline \multicolumn{10}{|l|}{ Suspended solids, residue on evaporation at 105} \\
\hline degrees Celsius, $\mathrm{mg} / \mathrm{L}$ & 102 & 83 & 44 & 79 & 160 & 4 & 0 & 33 & 219 \\
\hline Nitrogen, total, ammonia plus organic as $\mathrm{N}, \mathrm{mg} / \mathrm{L}$ & 1.35 & 0.45 & 1.05 & 1.20 & 1.65 & 4 & 0 & 0.99 & 2.00 \\
\hline Nitrogen, dissolved, ammonia as $\mathrm{N}, \mathrm{mg} / \mathrm{L}$ & \multicolumn{5}{|c|}{ Fewer than 3 uncensored values } & 4 & 2 & 0.040 & 0.047 \\
\hline Nitrogen, dissolved, nitrite plus nitrate as $\mathrm{N}, \mathrm{mg} / \mathrm{L}$ & 0.868 & 0.343 & 0.585 & 0.805 & 1.150 & 4 & 0 & 0.580 & 1.280 \\
\hline Orthophosphate, dissolved as $\mathrm{P}, \mathrm{mg} / \mathrm{L}$ & 0.009 & 0.002 & 0.008 & 0.009 & 0.010 & 4 & 0 & 0.007 & 0.010 \\
\hline Phosphorus, total as $\mathrm{P}, \mathrm{mg} / \mathrm{L}$ & 0.208 & 0.131 & 0.125 & 0.160 & 0.290 & 4 & 0 & 0.110 & 0.400 \\
\hline Carbon, dissolved, organic as $\mathrm{C}, \mathrm{mg} / \mathrm{L}$ & 11.5 & 1.9 & 10.5 & 10.6 & 12.5 & 4 & 0 & 10.4 & 14.4 \\
\hline Escherichia Coli, MPN/100 mL & -- & -- & -- & -- & -- & -- & -- & -- & -- \\
\hline Fecal coliform, MPN/100 mL & -- & -- & -- & -- & -- & -- & -- & -- & -- \\
\hline Copper, dissolved, $\mu \mathrm{g} / \mathrm{L}$ & 2.7 & 0.56 & 2.25 & 2.6 & 3.15 & 4 & 0 & 2.2 & 3.4 \\
\hline Copper, total recoverable, $\mu \mathrm{g} / \mathrm{L}$ & 7.0 & 3.8 & 4.9 & 5.5 & 9.2 & 4 & 0 & 4.3 & 12.7 \\
\hline Lead, dissolved, $\mu \mathrm{g} / \mathrm{L}$ & 0.06 & 0.01 & 0.06 & 0.06 & 0.07 & 4 & 0 & 0.05 & 0.08 \\
\hline Lead, total recoverable, $\mu \mathrm{g} / \mathrm{L}$ & 3.06 & 2.60 & 1.64 & 1.88 & 4.48 & 4 & 0 & 1.54 & 6.95 \\
\hline Manganese, dissolved, $\mu \mathrm{g} / \mathrm{L}$ & 29.5 & 17.7 & 19.3 & 22.3 & 39.6 & 4 & 0 & 17.5 & 55.8 \\
\hline Manganese, total recoverable, $\mu \mathrm{g} / \mathrm{L}$ & 326 & 238 & 201 & 217 & 450 & 4 & 0 & 185 & 682 \\
\hline Zinc, dissolved, $\mu \mathrm{g} / \mathrm{L}$ & 10.4 & 4.4 & 7.2 & 9.2 & 13.7 & 4 & 0 & 6.9 & 16.4 \\
\hline Zinc, total recoverable, $\mu \mathrm{g} / \mathrm{L}$ & 32.0 & 16.4 & 19.3 & 29.6 & 44.7 & 4 & 0 & 15.8 & 52.9 \\
\hline
\end{tabular}


Table A4. Statistics for concentrations and measurement values at Sand Creek at mouth near Commerce City by year, $2006-2010$.

$\left[\mu \mathrm{S} / \mathrm{cm}\right.$, microsiemens per centimeter at 25 degrees Celsius; ml, milliliter; $\mathrm{CaCO}_{3}$, calcium carbonate; mg/L, milligrams per liter; $\mu \mathrm{g} / \mathrm{L}$, micrograms per liter; mm, millimeter; N, nitrogen; P, phosphorus; C, carbon; SD, standard deviation; n, number of samples; nlt, number of "less thans" or censored data; \%, percentile; MPN, most probable number; --, not computed]

394839104570300 Sand Creek at mouth near Commerce City, Colorado, 2006

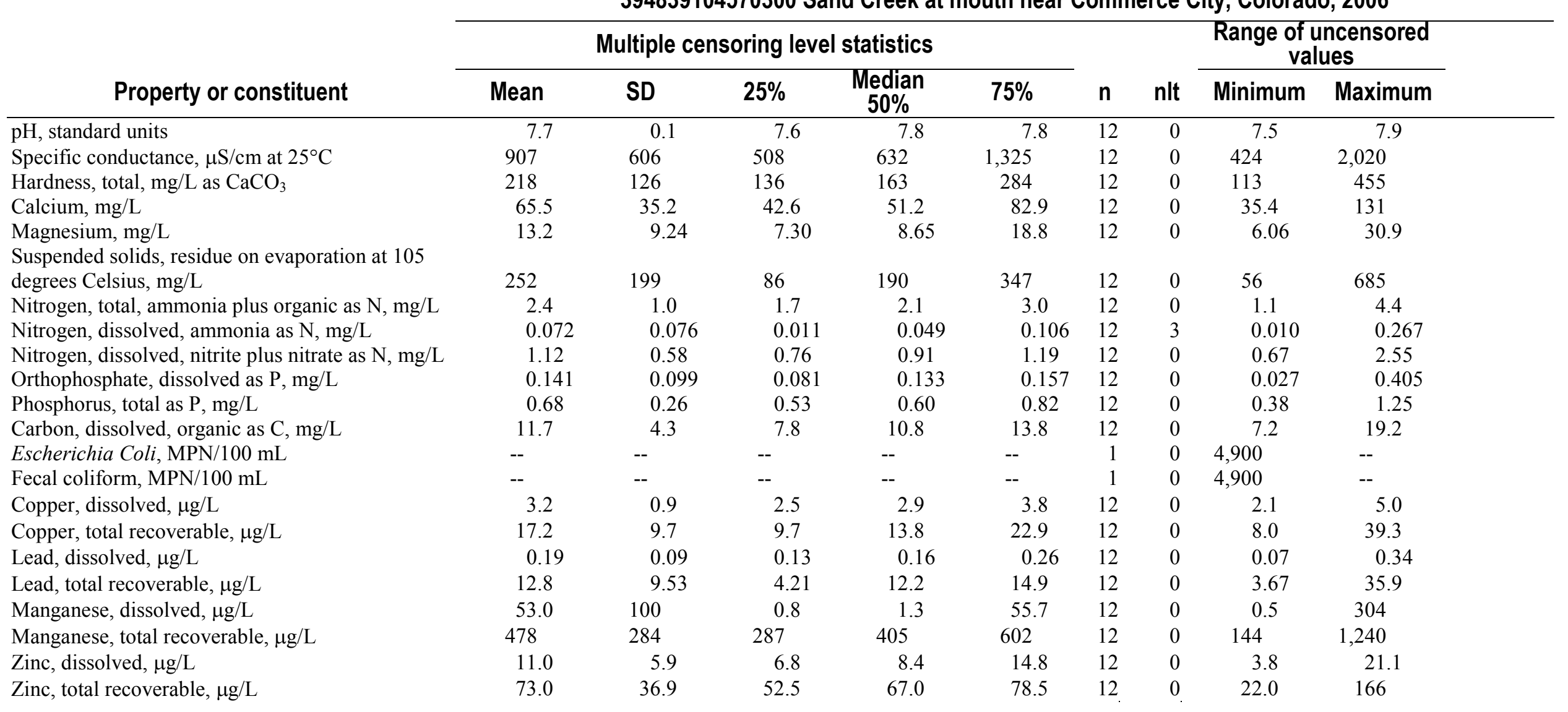


Table A4. Statistics for concentrations and measurement values at Sand Creek at mouth near Commerce City by year, 2006-2010.-Continued

$\left[\mu \mathrm{S} / \mathrm{cm}\right.$, microsiemens per centimeter at 25 degrees Celsius; ml, milliliter; $\mathrm{CaCO}_{3}$, calcium carbonate; mg/L, milligrams per liter; $\mu \mathrm{g} / \mathrm{L}$, micrograms per liter; mm, millimeter; N, nitrogen; P, phosphorus; C, carbon; SD, standard deviation; n, number of samples; nlt, number of "less thans" or censored data; \%, percentile; MPN, most probable number; --, not computed]

394839104570300 Sand Creek at mouth near Commerce City, Colorado, 2007 
Table A4. Statistics for concentrations and measurement values at Sand Creek at mouth near Commerce City by year, 2006-2010.-Continued

$\left[\mu \mathrm{S} / \mathrm{cm}\right.$, microsiemens per centimeter at 25 degrees Celsius; ml, milliliter; $\mathrm{CaCO}_{3}$, calcium carbonate; mg/L, milligrams per liter; $\mu \mathrm{g} / \mathrm{L}$, micrograms per liter; mm, millimeter; N, nitrogen; P, phosphorus; C, carbon; SD, standard deviation; n, number of samples; nlt, number of "less thans" or censored data; \%, percentile; MPN, most probable number; --, not computed]

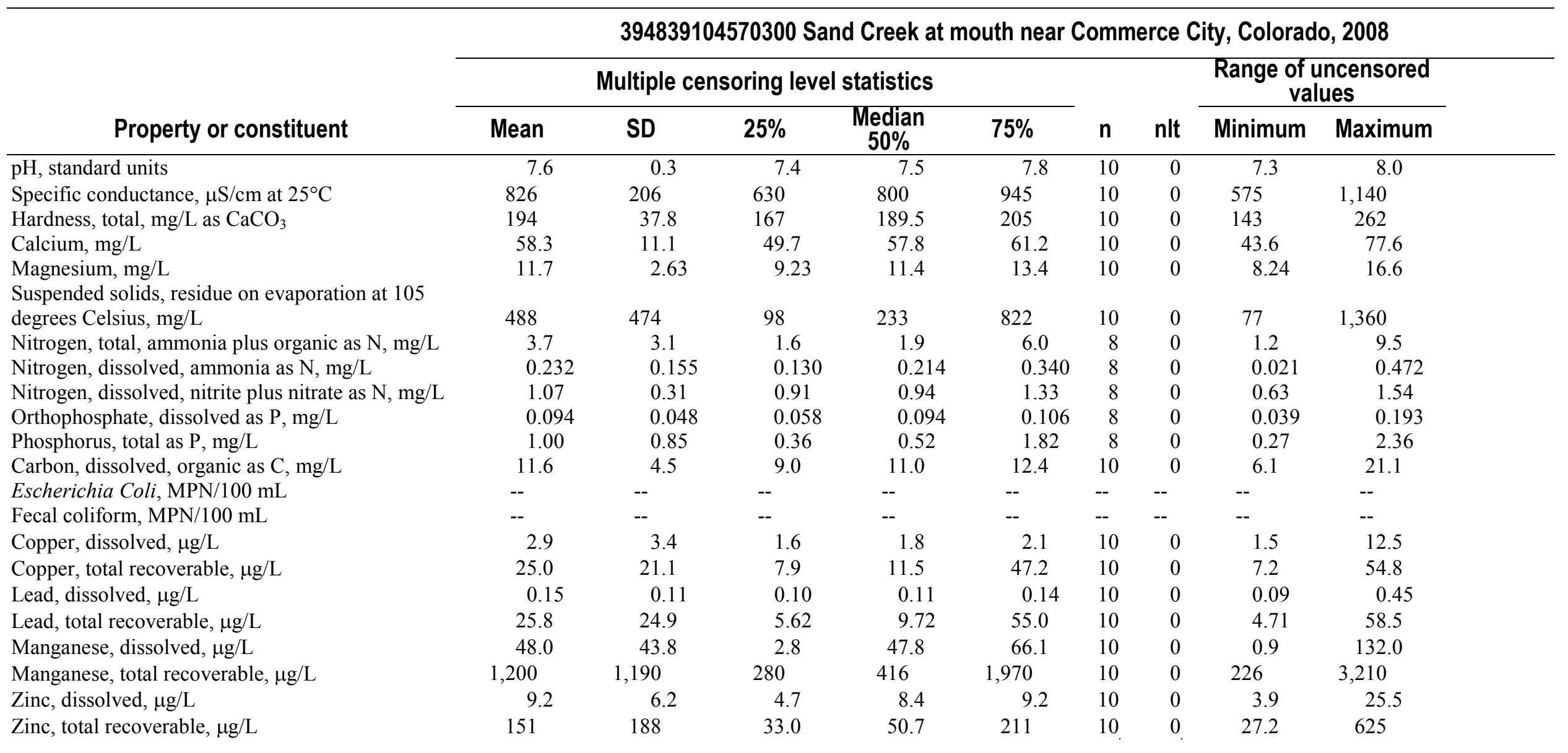


Table A4. Statistics for concentrations and measurement values at Sand Creek at mouth near Commerce City by year, 2006-2010.-Continued

$\left[\mu \mathrm{S} / \mathrm{cm}\right.$, microsiemens per centimeter at 25 degrees Celsius; ml, milliliter; $\mathrm{CaCO}_{3}$, calcium carbonate; mg/L, milligrams per liter; $\mu \mathrm{g} / \mathrm{L}$, micrograms per liter; mm, millimeter; N, nitrogen; P, phosphorus; C, carbon; SD, standard deviation; n, number of samples; nlt, number of "less thans" or censored data; \%, percentile; MPN, most probable number; --, not computed]

\begin{tabular}{|c|c|c|c|c|c|c|c|c|c|}
\hline \multirow[b]{3}{*}{ Property or constituent } & \multicolumn{9}{|c|}{394839104570300 Sand Creek at mouth near Commerce City, Colorado, 2009} \\
\hline & \multicolumn{5}{|c|}{ Multiple censoring level statistics } & \multirow[b]{2}{*}{$\mathbf{n}$} & \multirow[b]{2}{*}{ nlt } & \multicolumn{2}{|c|}{$\begin{array}{l}\text { Range of uncensored } \\
\text { values }\end{array}$} \\
\hline & Mean & SD & $25 \%$ & $\begin{array}{l}\text { Median } \\
50 \%\end{array}$ & $75 \%$ & & & Minimum & Maximum \\
\hline $\mathrm{pH}$, standard units & 7.37 & 0.1 & 7.3 & 7.35 & 7.45 & 4 & 0 & 7.3 & 7.5 \\
\hline Specific conductance, $\mu \mathrm{S} / \mathrm{cm}$ at $25^{\circ} \mathrm{C}$ & 691 & 185 & 552 & 692 & 829 & 4 & 0 & 470 & 908 \\
\hline Hardness, total, $\mathrm{mg} / \mathrm{L}$ as $\mathrm{CaCO}_{3}$ & 188 & 52.2 & 148 & 192 & 228 & 4 & 0 & 123 & 245 \\
\hline Magnesium, mg/L & 11.0 & 3.29 & 8.50 & 11.1 & 13.4 & 4 & 0 & 6.91 & 14.7 \\
\hline Suspended solids, residue on evaporation at 105 & & & & & & & & & \\
\hline $\begin{array}{l}\text { degrees Celsius, } \mathrm{mg} / \mathrm{L} \\
\text { Nitrogen total ammonia plus organic as } \mathrm{N} \text { mg/L }\end{array}$ & 242 & 98 & 185 & 200 & 299 & 4 & 0 & 180 & 388 \\
\hline Nitrogen, total, ammonia plus organic as $\mathrm{N}, \mathrm{mg} / \mathrm{L}$ & 2.3 & 0.48 & 2 & 2.45 & 2.6 & 4 & 0 & 1.6 & 2.7 \\
\hline Nitrogen, dissolved, ammonia as $\mathrm{N}, \mathrm{mg} / \mathrm{L}$ & Fewer than $3 \mathrm{u}$ & ensored va & & & & 4 & 2 & 0.090 & 0.123 \\
\hline Nitrogen, dissolved, nitrite plus nitrate as $\mathrm{N}, \mathrm{mg} / \mathrm{L}$ & 0.52 & 0.16 & 0.44 & 0.46 & 0.61 & 4 & 0 & 0.42 & 0.76 \\
\hline Orthophosphate, dissolved as $\mathrm{P}, \mathrm{mg} / \mathrm{L}$ & 0.059 & 0.043 & 0.024 & 0.054 & 0.094 & 4 & 0 & 0.017 & 0.112 \\
\hline Phosphorus, total as $\mathrm{P}, \mathrm{mg} / \mathrm{L}$ & 0.61 & 0.15 & 0.50 & 0.66 & 0.72 & 4 & 0 & 0.39 & 0.74 \\
\hline Escherichia Coli, MPN/100 mL & -- & -- & -- & -- & -- & -- & -- & -- & -- \\
\hline Fecal coliform, MPN/100 mL & -- & -- & -- & -- & -- & -- & -- & -- & -- \\
\hline Copper, dissolved, $\mu \mathrm{g} / \mathrm{L}$ & 4.6 & 2.5 & 3.0 & 4.7 & 6.2 & 4 & 0 & 1.5 & 7.5 \\
\hline Copper, total recoverable, $\mu \mathrm{g} / \mathrm{L}$ & 18.3 & 4.8 & 14.6 & 19.0 & 22.1 & 4 & 0 & 12.2 & 23.1 \\
\hline Lead, dissolved, $\mu \mathrm{g} / \mathrm{L}$ & 0.46 & 0.23 & 0.31 & 0.46 & 0.61 & 4 & 0 & 0.18 & 0.74 \\
\hline Lead, total recoverable, $\mu \mathrm{g} / \mathrm{L}$ & 30.3 & 12.2 & 20.6 & 29.7 & 40.0 & 4 & 0 & 17.2 & 44.7 \\
\hline Manganese, dissolved, $\mu \mathrm{g} / \mathrm{L}$ & 134 & 174 & 35.2 & 67.0 & 233 & 4 & 0 & 10.6 & 391 \\
\hline Manganese, total recoverable, $\mu \mathrm{g} / \mathrm{L}$ & 466 & 128 & 368 & 472 & 565 & 4 & 0 & 311 & 609 \\
\hline Zinc, dissolved, $\mu \mathrm{g} / \mathrm{L}$ & 570 & 415 & 300 & 438 & 841 & 4 & 0 & 237 & 1,170 \\
\hline Zinc, total recoverable, $\mu \mathrm{g} / \mathrm{L}$ & 3,360 & 1,950 & 1,680 & 3,340 & 5,040 & 4 & 0 & 1,530 & 5,230 \\
\hline
\end{tabular}


Table A4. Statistics for concentrations and measurement values at Sand Creek at mouth near Commerce City by year, 2006-2010.-Continued

$\left[\mu \mathrm{S} / \mathrm{cm}\right.$, microsiemens per centimeter at 25 degrees Celsius; ml, milliliter; $\mathrm{CaCO}_{3}$, calcium carbonate; mg/L, milligrams per liter; $\mu \mathrm{g} / \mathrm{L}$, micrograms per liter; mm, millimeter; N, nitrogen; P, phosphorus; C, carbon; SD, standard deviation; n, number of samples; nlt, number of "less thans" or censored data; \%, percentile; MPN, most probable number; --, not computed]

\begin{tabular}{|c|c|c|c|c|c|c|c|c|c|}
\hline \multirow[b]{3}{*}{ Property or constituent } & \multicolumn{9}{|c|}{394839104570300 Sand Creek at mouth near Commerce City, Colorado, 2010} \\
\hline & \multicolumn{5}{|c|}{ Multiple censoring level statistics } & \multirow[b]{2}{*}{$\mathbf{n}$} & \multirow[b]{2}{*}{ nlt } & \multicolumn{2}{|c|}{$\begin{array}{l}\text { Range of uncensored } \\
\text { values }\end{array}$} \\
\hline & Mean & SD & $25 \%$ & $\begin{array}{l}\text { Median } \\
50 \%\end{array}$ & $75 \%$ & & & Minimum & Maximum \\
\hline $\mathrm{pH}$, standard units & 7.42 & 0.13 & 7.3 & 7.4 & 7.5 & 5 & 0 & 7.3 & 7.6 \\
\hline Specific conductance, $\mu \mathrm{S} / \mathrm{cm}$ at $25^{\circ} \mathrm{C}$ & 862 & 507 & 552 & 686 & 950 & 5 & 0 & 423 & 1,700 \\
\hline Hardness, total, $\mathrm{mg} / \mathrm{L}$ as $\mathrm{CaCO}_{3}$ & 175 & 47.8 & 155 & 170 & 190 & 5 & 0 & 115 & 245 \\
\hline Calcium, mg/L & 53.4 & 13.8 & 48.0 & 52.0 & 57.9 & 5 & 0 & 35.9 & 73.4 \\
\hline Magnesium, mg/L & 10.1 & 3.26 & 8.52 & 9.86 & 10.9 & 5 & 0 & 6.17 & 15.0 \\
\hline $\begin{array}{l}\text { Suspended solids, residue on evaporation at } 105 \\
\text { degrees Celsius, } \mathrm{mg} / \mathrm{L}\end{array}$ & 557 & 208 & 445 & 530 & 734 & 5 & 0 & 284 & 790 \\
\hline Nitrogen, total, ammonia plus organic as $\mathrm{N}, \mathrm{mg} / \mathrm{L}$ & 3.3 & 0.98 & 2.5 & 3.3 & 4.2 & 5 & 0 & 2.2 & 4.4 \\
\hline Nitrogen, dissolved, ammonia as $\mathrm{N}, \mathrm{mg} / \mathrm{L}$ & Fewer than $3 \mathrm{u}$ & ensored val & & & & 5 & 3 & 0.011 & 0.018 \\
\hline Nitrogen, dissolved, nitrite plus nitrate as $\mathrm{N}, \mathrm{mg} / \mathrm{L}$ & 0.5 & 0.03 & 0.49 & 0.49 & 0.52 & 5 & 0 & 0.46 & 0.53 \\
\hline Orthophosphate, dissolved as $\mathrm{P}, \mathrm{mg} / \mathrm{L}$ & 0.056 & 0.026 & 0.035 & 0.069 & 0.072 & 5 & 0 & 0.022 & 0.082 \\
\hline Phosphorus, total as $\mathrm{P}, \mathrm{mg} / \mathrm{L}$ & 1.07 & 0.36 & 0.77 & 1.09 & 1.38 & 5 & 0 & 0.63 & 1.46 \\
\hline Carbon, dissolved, organic as $\mathrm{C}, \mathrm{mg} / \mathrm{L}$ & 8.9 & 3.9 & 6.4 & 8.2 & 8.7 & 5 & 0 & 5.8 & 15.5 \\
\hline Escherichia Coli, MPN/100 mL & -- & -- & -- & -- & -- & -- & -- & -- & -- \\
\hline Fecal coliform, MPN/100 mL & -- & -- & -- & -- & -- & -- & -- & -- & -- \\
\hline Copper, dissolved, $\mu \mathrm{g} / \mathrm{L}$ & 1.7 & 0.6 & 1.2 & 1.6 & 2.3 & 5 & 0 & 1.2 & 2.4 \\
\hline Copper, total recoverable, $\mu \mathrm{g} / \mathrm{L}$ & 29.3 & 12.4 & 19.2 & 25.4 & 38.9 & 5 & 0 & 17.3 & 45.6 \\
\hline Lead, dissolved, $\mu \mathrm{g} / \mathrm{L}$ & 0.12 & 0.09 & 0.07 & 0.10 & 0.12 & 5 & 0 & 0.04 & 0.28 \\
\hline Lead, total recoverable, $\mu \mathrm{g} / \mathrm{L}$ & 33.2 & 18.0 & 19.2 & 31.1 & 39.5 & 5 & 0 & 15.8 & 60.5 \\
\hline Manganese, dissolved, $\mu \mathrm{g} / \mathrm{L}$ & 31.86 & 45.22 & 2.7 & 7.8 & 39 & 5 & 0 & 1.8 & 108 \\
\hline Manganese, total recoverable, $\mu \mathrm{g} / \mathrm{L}$ & 905 & 332 & 623 & 988 & 1,080 & 5 & 0 & 514 & 1,320 \\
\hline Zinc, dissolved, $\mu \mathrm{g} / \mathrm{L}$ & 90.4 & 84.5 & 22.2 & 80.9 & 120 & 5 & 0 & 10.2 & 219 \\
\hline Zinc, total recoverable, $\mu \mathrm{g} / \mathrm{L}$ & 1,467 & 1,708 & 528 & 562 & 1,360 & 5 & 0 & 436 & 4,450 \\
\hline
\end{tabular}


Table A5. Statistics for concentrations and measurement values at South Platte River at Henderson by year, 2006-2010.

$\left[\mu \mathrm{S} / \mathrm{cm}\right.$, microsiemens per centimeter at 25 degrees Celsius; ml, milliliter; $\mathrm{CaCO}_{3}$, calcium carbonate; mg/L, milligrams per liter; $\mu \mathrm{g} / \mathrm{L}$, micrograms per liter; mm, millimeter; N, nitrogen; P, phosphorus; C, carbon; SD, standard deviation; $n$, number of samples; nlt, number of "less thans" or censored data; \%, percentile; MPN, most probable number; --, not computed]

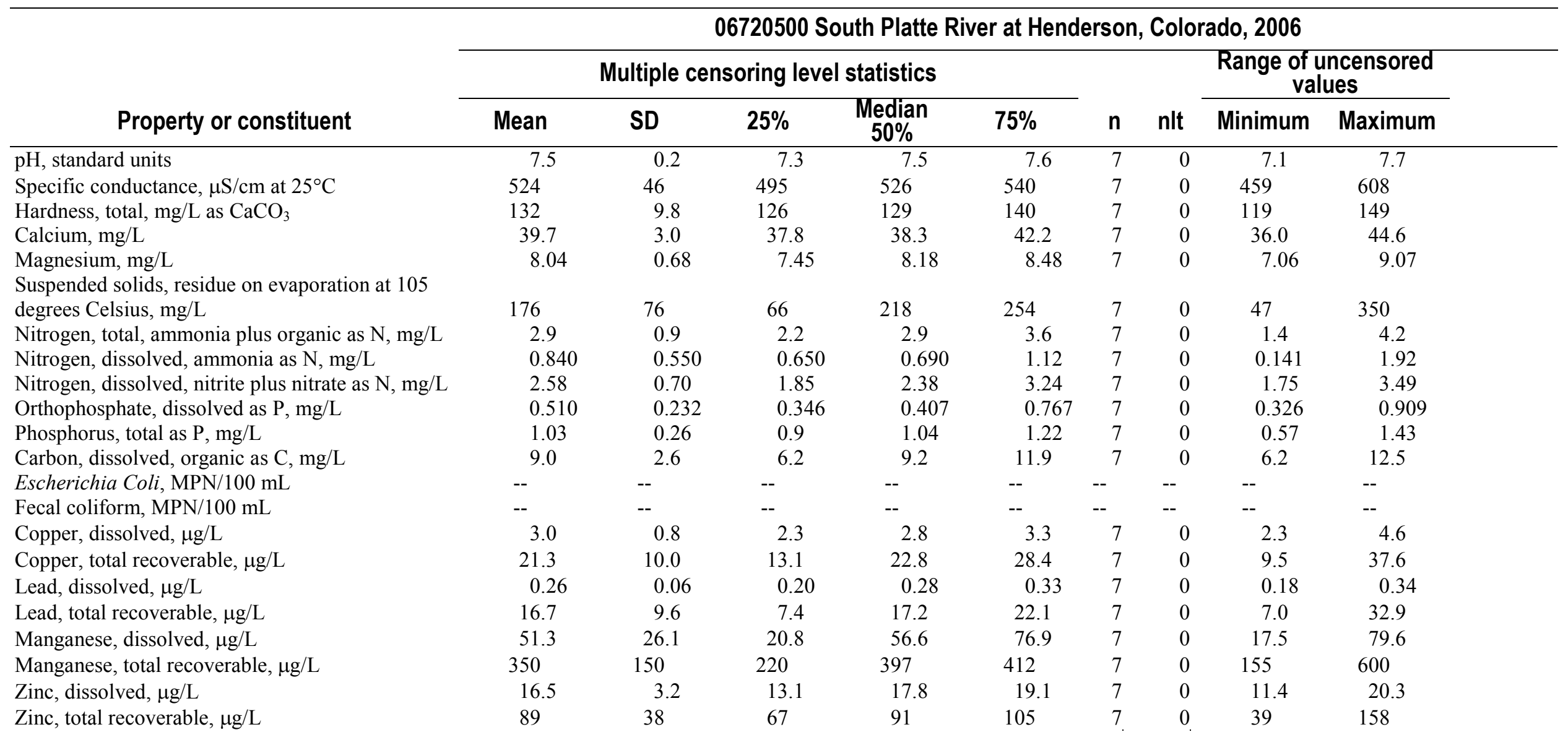


Table A5. Statistics for concentrations and measurement values at South Platte River at Henderson by year, 2006-2010.-Continued

$\left[\mu \mathrm{S} / \mathrm{cm}\right.$, microsiemens per centimeter at 25 degrees Celsius; ml, milliliter; $\mathrm{CaCO}_{3}$, calcium carbonate; mg/L, milligrams per liter; $\mu \mathrm{g} / \mathrm{L}$, micrograms per liter; mm, millimeter; N, nitrogen; P, phosphorus; C, carbon; SD, standard deviation; n, number of samples; nlt, number of "less thans" or censored data; \%, percentile; MPN, most probable number; --, not computed]

\begin{tabular}{|c|c|c|c|c|c|c|c|c|c|}
\hline \multirow[b]{3}{*}{ Property or constituent } & \multicolumn{9}{|c|}{06720500 South Platte River at Henderson, Colorado, 2007} \\
\hline & \multicolumn{5}{|c|}{ Multiple censoring level statistics } & \multirow[b]{2}{*}{ n } & \multirow[b]{2}{*}{ nlt } & \multicolumn{2}{|c|}{$\begin{array}{l}\text { Range of uncensored } \\
\text { values }\end{array}$} \\
\hline & Mean & SD & $25 \%$ & $\begin{array}{l}\text { Median } \\
50 \%\end{array}$ & $75 \%$ & & & Minimum & Maximum \\
\hline $\mathrm{pH}$, standard units & 7.38 & 0.13 & 7.3 & 7.4 & 7.4 & 6 & 0 & 7.2 & 7.6 \\
\hline Specific conductance, $\mu \mathrm{S} / \mathrm{cm}$ at $25^{\circ} \mathrm{C}$ & 396 & 24 & 383 & 402 & 415 & 6 & 0 & 355 & 419 \\
\hline Hardness, total, $\mathrm{mg} / \mathrm{L}$ as $\mathrm{CaCO}_{3}$ & 107 & 7.2 & 102 & 109 & 112 & 6 & 0 & 95 & 115 \\
\hline Magnesium, mg/L & 6.82 & 0.55 & 6.55 & 6.79 & 7.27 & 6 & 0 & 5.99 & 7.53 \\
\hline $\begin{array}{l}\text { Suspended solids, residue on evaporation at } 105 \\
\text { degrees Celsius, } \mathrm{mg} / \mathrm{L}\end{array}$ & 154 & 88 & 98 & 132 & 156 & 6 & 0 & 80 & 324 \\
\hline Nitrogen, total, ammonia plus organic as $\mathrm{N}, \mathrm{mg} / \mathrm{L}$ & 1.7 & 0.69 & 1.3 & 1.5 & 2.3 & 6 & 0 & 0.96 & 2.8 \\
\hline Nitrogen, dissolved, ammonia as $\mathrm{N}, \mathrm{mg} / \mathrm{L}$ & 0.242 & 0.074 & 0.217 & 0.267 & 0.295 & 6 & 0 & 0.107 & 0.298 \\
\hline Nitrogen, dissolved, nitrite plus nitrate as $\mathrm{N}, \mathrm{mg} / \mathrm{L}$ & 1.34 & 0.20 & 1.18 & 1.30 & 1.38 & 6 & 0 & 1.16 & 1.72 \\
\hline Orthophosphate, dissolved as $\mathrm{P}, \mathrm{mg} / \mathrm{L}$ & 0.208 & 0.047 & 0.165 & 0.203 & 0.225 & 6 & 0 & 0.164 & 0.290 \\
\hline Phosphorus, total as $\mathrm{P}, \mathrm{mg} / \mathrm{L}$ & 0.637 & 0.283 & 0.41 & 0.535 & 0.9 & 6 & 0 & 0.37 & 1.07 \\
\hline Escherichia Coli, MPN/100 mL & -- & -- & -- & -- & -- & 1 & 0 & 7,900 & -- \\
\hline Fecal coliform, MPN/100 mL & -- & -- & -- & -- & -- & 1 & 0 & 13,000 & -- \\
\hline Copper, dissolved, $\mu \mathrm{g} / \mathrm{L}$ & 3.3 & 0.8 & 2.7 & 3.1 & 4.0 & 6 & 0 & 2.5 & 4.4 \\
\hline Copper, total recoverable, $\mu \mathrm{g} / \mathrm{L}$ & 25.1 & 10.7 & 15.8 & 25.6 & 27.4 & 6 & 0 & 13.0 & 43.2 \\
\hline Lead, dissolved, $\mu \mathrm{g} / \mathrm{L}$ & 0.20 & 0.04 & 0.19 & 0.22 & 0.22 & 6 & 0 & 0.13 & 0.23 \\
\hline Lead, total recoverable, $\mu \mathrm{g} / \mathrm{L}$ & 32.4 & 23.1 & 13.8 & 27.5 & 45.4 & 6 & 0 & 9.1 & 70.9 \\
\hline Manganese, dissolved, $\mu \mathrm{g} / \mathrm{L}$ & 48.8 & 23.8 & 31.0 & 44.1 & 57.9 & 6 & 0 & 25.9 & 89.9 \\
\hline Manganese, total recoverable, $\mu \mathrm{g} / \mathrm{L}$ & 308 & 142 & 172 & 291 & 451 & 6 & 0 & 149 & 493 \\
\hline Zinc, dissolved, $\mu \mathrm{g} / \mathrm{L}$ & 21.8 & 2.9 & 19.9 & 21.8 & 23.6 & 6 & 0 & 17.6 & 26.0 \\
\hline Zinc, total recoverable, $\mu \mathrm{g} / \mathrm{L}$ & 135 & 54 & 86 & 141 & 145 & 6 & 0 & 71 & 224 \\
\hline
\end{tabular}


Table A5. Statistics for concentrations and measurement values at South Platte River at Henderson by year, 2006-2010.-Continued

$\left[\mu \mathrm{S} / \mathrm{cm}\right.$, microsiemens per centimeter at 25 degrees Celsius; ml, milliliter; $\mathrm{CaCO}_{3}$, calcium carbonate; mg/L, milligrams per liter; $\mu \mathrm{g} / \mathrm{L}$, micrograms per liter; mm, millimeter; N, nitrogen; P, phosphorus; C, carbon; SD, standard deviation; n, number of samples; nlt, number of "less thans" or censored data; \%, percentile; MPN, most probable number; --, not computed]

\begin{tabular}{|c|c|c|c|c|c|c|c|c|c|}
\hline \multirow[b]{3}{*}{ Property or constituent } & \multicolumn{9}{|c|}{06720500 South Platte River at Henderson, Colorado, 2008} \\
\hline & \multicolumn{5}{|c|}{ Multiple censoring level statistics } & \multirow[b]{2}{*}{$\mathbf{n}$} & \multirow[b]{2}{*}{ nlt } & \multicolumn{2}{|c|}{$\begin{array}{c}\text { Range of uncensored } \\
\text { values }\end{array}$} \\
\hline & Mean & SD & $25 \%$ & $\begin{array}{l}\text { Median } \\
50 \%\end{array}$ & $75 \%$ & & & Minimum & Maximum \\
\hline $\mathrm{pH}$, standard units & 7.2 & 0.3 & 7.0 & 7.2 & 7.5 & 6 & 0 & 6.6 & 7.5 \\
\hline Specific conductance, $\mu \mathrm{S} / \mathrm{cm}$ at $25^{\circ} \mathrm{C}$ & 527 & 167 & 510 & 572 & 650 & 6 & 0 & 205 & 651 \\
\hline Hardness, total, $\mathrm{mg} / \mathrm{L}$ as $\mathrm{CaCO}_{3}$ & 140 & 13.7 & 128 & 139 & 151 & 6 & 0 & 124 & 159 \\
\hline Magnesium, mg/L & 8.76 & 1.13 & 7.86 & 8.69 & 10.00 & 6 & 0 & 7.33 & 10.00 \\
\hline $\begin{array}{l}\text { Suspended solids, residue on evaporation at } 105 \\
\text { degrees Celsius, } \mathrm{mg} / \mathrm{L}\end{array}$ & 210 & 187 & 62 & 162 & 284 & 6 & 0 & 44 & 545 \\
\hline Nitrogen, total, ammonia plus organic as $\mathrm{N}, \mathrm{mg} / \mathrm{L}$ & 4.05 & 2.69 & 2.5 & 3 & 4 & 6 & 0 & 2.4 & 9.4 \\
\hline Nitrogen, dissolved, ammonia as $\mathrm{N}, \mathrm{mg} / \mathrm{L}$ & 1.26 & 1.00 & 0.614 & 0.785 & 1.63 & 6 & 0 & 0.578 & 3.14 \\
\hline Nitrogen, dissolved, nitrite plus nitrate as $\mathrm{N}, \mathrm{mg} / \mathrm{L}$ & 1.99 & 0.54 & 1.68 & 1.83 & 2.18 & 6 & 0 & 1.46 & 2.98 \\
\hline Orthophosphate, dissolved as $\mathrm{P}, \mathrm{mg} / \mathrm{L}$ & 0.671 & 0.246 & 0.445 & 0.652 & 0.911 & 6 & 0 & 0.374 & 0.993 \\
\hline Phosphorus, total as $\mathrm{P}, \mathrm{mg} / \mathrm{L}$ & 1.39 & 0.75 & 0.92 & 1.10 & 1.53 & 6 & 0 & 0.86 & 2.85 \\
\hline Escherichia Coli, MPN/100 mL & -- & -- & -- & -- & -- & 1 & 0 & 23,000 & -- \\
\hline Fecal coliform, MPN/100 mL & -- & -- & -- & -- & -- & 1 & 0 & 23,000 & -- \\
\hline Copper, dissolved, $\mu \mathrm{g} / \mathrm{L}$ & 2.4 & 0.4 & 2.3 & 2.6 & 2.7 & 6 & 0 & 1.7 & 2.7 \\
\hline Copper, total recoverable, $\mu \mathrm{g} / \mathrm{L}$ & 25.4 & 17.4 & 10.5 & 23.8 & 27.4 & 6 & 0 & 9.4 & 57.5 \\
\hline Lead, dissolved, $\mu \mathrm{g} / \mathrm{L}$ & 0.23 & 0.07 & 0.18 & 0.22 & 0.30 & 6 & 0 & 0.16 & 0.32 \\
\hline Lead, total recoverable, $\mu \mathrm{g} / \mathrm{L}$ & 23.5 & 17.9 & 7.5 & 21.3 & 30.7 & 6 & 0 & 6.3 & 54.0 \\
\hline Manganese, dissolved, $\mu \mathrm{g} / \mathrm{L}$ & 176 & 288 & 26.9 & 52.8 & 140 & 6 & 0 & 25.2 & 757 \\
\hline Manganese, total recoverable, $\mu \mathrm{g} / \mathrm{L}$ & 639 & 602 & 282 & 432 & 596 & 6 & 0 & 252 & 1,840 \\
\hline Zinc, dissolved, $\mu \mathrm{g} / \mathrm{L}$ & 15.1 & 4.6 & 11.7 & 15.4 & 17.0 & 6 & 0 & 9.0 & 21.9 \\
\hline Zinc, total recoverable, $\mu \mathrm{g} / \mathrm{L}$ & 105 & 77 & 45 & 90 & 113 & 6 & 0 & 42 & 252 \\
\hline
\end{tabular}


Table A5. Statistics for concentrations and measurement values at South Platte River at Henderson by year, 2006-2010.-Continued

$\left[\mu \mathrm{S} / \mathrm{cm}\right.$, microsiemens per centimeter at 25 degrees Celsius; ml, milliliter; $\mathrm{CaCO}_{3}$, calcium carbonate; mg/L, milligrams per liter; $\mu \mathrm{g} / \mathrm{L}$, micrograms per liter; mm, millimeter; N, nitrogen; P, phosphorus; C, carbon; SD, standard deviation; n, number of samples; nlt, number of "less thans" or censored data; \%, percentile; MPN, most probable number; --, not computed]

\begin{tabular}{|c|c|c|c|c|c|c|c|c|c|}
\hline \multirow[b]{3}{*}{ Property or constituent } & \multicolumn{9}{|c|}{06720500 South Platte River at Henderson, Colorado, 2009} \\
\hline & \multicolumn{5}{|c|}{ Multiple censoring level statistics } & \multirow[b]{2}{*}{$\mathbf{n}$} & \multirow[b]{2}{*}{ nlt } & \multicolumn{2}{|c|}{$\begin{array}{c}\text { Range of uncensored } \\
\text { values }\end{array}$} \\
\hline & Mean & SD & $25 \%$ & $\begin{array}{l}\text { Median } \\
50 \%\end{array}$ & $75 \%$ & & & Minimum & Maximum \\
\hline $\mathrm{pH}$, standard units & 7.4 & 0.2 & 7.2 & 7.4 & 7.5 & 10 & 0 & 7.0 & 7.6 \\
\hline Specific conductance, $\mu \mathrm{S} / \mathrm{cm}$ at $25^{\circ} \mathrm{C}$ & 578 & 110 & 505 & 580 & 702 & 10 & 0 & 365 & 710 \\
\hline Hardness, total, $\mathrm{mg} / \mathrm{L}$ as $\mathrm{CaCO}_{3}$ & 151 & 27.6 & 133 & 149.5 & 165 & 10 & 0 & 100 & 193 \\
\hline Magnesium, mg/L & 9.25 & 1.82 & 8.12 & 8.86 & 10.4 & 10 & 0 & 6.0 & 11.8 \\
\hline $\begin{array}{l}\text { Suspended solids, residue on evaporation at } 105 \\
\text { degrees Celsius, mg/L }\end{array}$ & 138 & 66 & 94 & 126 & 179 & 10 & 2 & 53 & 250 \\
\hline Nitrogen, total, ammonia plus organic as $\mathrm{N}, \mathrm{mg} / \mathrm{L}$ & 2.3 & 0.61 & 2.0 & 2.3 & 2.9 & 9 & 0 & 1.2 & 3.1 \\
\hline Nitrogen, dissolved, ammonia as $\mathrm{N}, \mathrm{mg} / \mathrm{L}$ & 0.479 & 0.319 & 0.230 & 0.416 & 0.717 & 9 & 1 & 0.167 & 1.10 \\
\hline Nitrogen, dissolved, nitrite plus nitrate as $\mathrm{N}, \mathrm{mg} / \mathrm{L}$ & 2.26 & 1.06 & 1.86 & 2.06 & 2.13 & 9 & 0 & 0.96 & 4.64 \\
\hline Orthophosphate, dissolved as $\mathrm{P}, \mathrm{mg} / \mathrm{L}$ & 0.384 & 0.162 & 0.297 & 0.367 & 0.451 & 9 & 0 & 0.152 & 0.725 \\
\hline Phosphorus, total as $\mathrm{P}, \mathrm{mg} / \mathrm{L}$ & 0.83 & 0.19 & 0.70 & 0.73 & 0.96 & 9 & 0 & 0.63 & 1.18 \\
\hline Escherichia Coli, MPN/100 mL & -- & -- & -- & -- & -- & -- & -- & -- & -- \\
\hline Fecal coliform, MPN/100 mL & -- & -- & -- & -- & -- & -- & -- & -- & -- \\
\hline Copper, dissolved, $\mu \mathrm{g} / \mathrm{L}$ & 3.1 & 0.7 & 2.7 & 3.0 & 3.5 & 0 & 0 & 2.2 & 4.6 \\
\hline Copper, total recoverable, $\mu \mathrm{g} / \mathrm{L}$ & 19.0 & 8.6 & 12.6 & 17.9 & 22.1 & 10 & 0 & 9.1 & 33.5 \\
\hline Lead, dissolved, $\mu \mathrm{g} / \mathrm{L}$ & 0.21 & 0.11 & 0.13 & 0.19 & 0.29 & 10 & 0 & 0.07 & 0.41 \\
\hline Lead, total recoverable, $\mu \mathrm{g} / \mathrm{L}$ & 16.5 & 10.0 & 11.4 & 14.1 & 17.4 & 10 & 0 & 5.1 & 36.0 \\
\hline Manganese, dissolved, $\mu \mathrm{g} / \mathrm{L}$ & 32.9 & 26.8 & 3.8 & 31.3 & 56.0 & 10 & 0 & 0.6 & 77.4 \\
\hline Manganese, total recoverable, $\mu \mathrm{g} / \mathrm{L}$ & 314 & 125 & 231 & 309 & 368 & 10 & 0 & 138 & 580 \\
\hline Zinc, dissolved, $\mu \mathrm{g} / \mathrm{L}$ & 20.4 & 10.2 & 14.4 & 16.5 & 23.6 & 10 & 0 & 11.4 & 45.8 \\
\hline Zinc, total recoverable, $\mu \mathrm{g} / \mathrm{L}$ & 108 & 84 & 57 & 74 & 150 & 10 & 0 & 32 & 308 \\
\hline
\end{tabular}


Table A5. Statistics for concentrations and measurement values at South Platte River at Henderson by year, 2006-2010.-Continued

$\left[\mu \mathrm{S} / \mathrm{cm}\right.$, microsiemens per centimeter at 25 degrees Celsius; ml, milliliter; $\mathrm{CaCO}_{3}$, calcium carbonate; mg/L, milligrams per liter; $\mu \mathrm{g} / \mathrm{L}$, micrograms per liter; mm, millimeter; N, nitrogen; P, phosphorus; C, carbon; SD, standard deviation; n, number of samples; nlt, number of "less thans" or censored data; \%, percentile; MPN, most probable number; --, not computed]

\begin{tabular}{|c|c|c|c|c|c|c|c|c|c|}
\hline \multirow[b]{3}{*}{ Property or constituent } & \multicolumn{9}{|c|}{06720500 South Platte River at Henderson, Colorado, 2010} \\
\hline & \multicolumn{5}{|c|}{ Multiple censoring level statistics } & \multirow[b]{2}{*}{$\mathbf{n}$} & \multirow[b]{2}{*}{ nlt } & \multicolumn{2}{|c|}{$\begin{array}{l}\text { Range of uncensored } \\
\text { values }\end{array}$} \\
\hline & Mean & SD & $25 \%$ & $\begin{array}{c}\text { Median } \\
50 \%\end{array}$ & $75 \%$ & & & Minimum & Maximum \\
\hline $\mathrm{pH}$, standard units & 7.2 & 0.2 & 7.1 & 7.2 & 7.3 & 5 & 0 & 7.0 & 7.4 \\
\hline Specific conductance, $\mu \mathrm{S} / \mathrm{cm}$ at $25^{\circ} \mathrm{C}$ & 789 & 375 & 540 & 563 & 1,130 & 5 & 0 & 454 & 1,260 \\
\hline Hardness, total, $\mathrm{mg} / \mathrm{L}$ as $\mathrm{CaCO}_{3}$ & 176 & 48.4 & 148 & 161 & 226 & 5 & 0 & 118 & 226 \\
\hline Magnesium, mg/L & 12.0 & 4.46 & 9.16 & 10.1 & 16.3 & 5 & 0 & 7.27 & 17.2 \\
\hline Suspended solids, residue on evaporation at 105 & & & & & & & & & \\
\hline degrees Celsius, mg/L & 225 & 102 & 150 & 196 & 286 & 5 & 0 & 122 & 370 \\
\hline Nitrogen, total, ammonia plus organic as $\mathrm{N}, \mathrm{mg} / \mathrm{L}$ & 4.1 & 2.1 & 2.8 & 3.8 & 6.0 & 5 & 0 & 1.6 & 6.4 \\
\hline Nitrogen, dissolved, ammonia as $\mathrm{N}, \mathrm{mg} / \mathrm{L}$ & 1.475 & 1.627 & 0.193 & 0.495 & 3.12 & 5 & 0 & 0.19 & 3.38 \\
\hline Nitrogen, dissolved, nitrite plus nitrate as $\mathrm{N}, \mathrm{mg} / \mathrm{L}$ & 2.09 & 0.77 & 1.56 & 1.97 & 1.98 & 5 & 0 & 1.52 & 3.42 \\
\hline Orthophosphate, dissolved as $\mathrm{P}, \mathrm{mg} / \mathrm{L}$ & 0.584 & 0.461 & 0.262 & 0.306 & 1.02 & 5 & 0 & 0.184 & 1.15 \\
\hline Phosphorus, total as $\mathrm{P}, \mathrm{mg} / \mathrm{L}$ & 1.31 & 0.31 & 1.20 & 1.39 & 1.48 & 5 & 0 & 0.84 & 1.68 \\
\hline Escherichia Coli, MPN/100 mL & -- & -- & -- & -- & -- & 1 & 0 & 310 & -- \\
\hline Fecal coliform, MPN/100 mL & -- & -- & -- & -- & -- & 1 & 0 & 310 & -- \\
\hline Copper, dissolved, $\mu \mathrm{g} / \mathrm{L}$ & 3.5 & 1.8 & 2.1 & 2.4 & 5.3 & 5 & 0 & 2.0 & 5.5 \\
\hline Copper, total recoverable, $\mu \mathrm{g} / \mathrm{L}$ & 40.9 & 23.7 & 16.1 & 43.5 & 63.2 & 3 & 0 & 16.1 & 63.2 \\
\hline Lead, dissolved, $\mu \mathrm{g} / \mathrm{L}$ & 0.20 & 0.11 & 0.11 & 0.16 & 0.27 & 5 & 0 & 0.10 & 0.35 \\
\hline Lead, total recoverable, $\mu \mathrm{g} / \mathrm{L}$ & 35.0 & 15.4 & 17.4 & 42.0 & 45.7 & 3 & 0 & 17.4 & 45.7 \\
\hline Manganese, dissolved, $\mu \mathrm{g} / \mathrm{L}$ & 11.6 & 6.5 & 8.1 & 12.1 & 17.2 & 5 & 0 & 2.6 & 18.2 \\
\hline Manganese, total recoverable, $\mu \mathrm{g} / \mathrm{L}$ & 599 & 215 & 366 & 642 & 789 & 3 & 0 & 366 & 789 \\
\hline Zinc, dissolved, $\mu \mathrm{g} / \mathrm{L}$ & 16.4 & 11.1 & 8.3 & 9.9 & 27.9 & 5 & 0 & 6.7 & 29.1 \\
\hline Zinc, total recoverable, $\mu \mathrm{g} / \mathrm{L}$ & 166 & 75 & 79 & 201 & 217 & 3 & 0 & 79 & 217 \\
\hline
\end{tabular}

